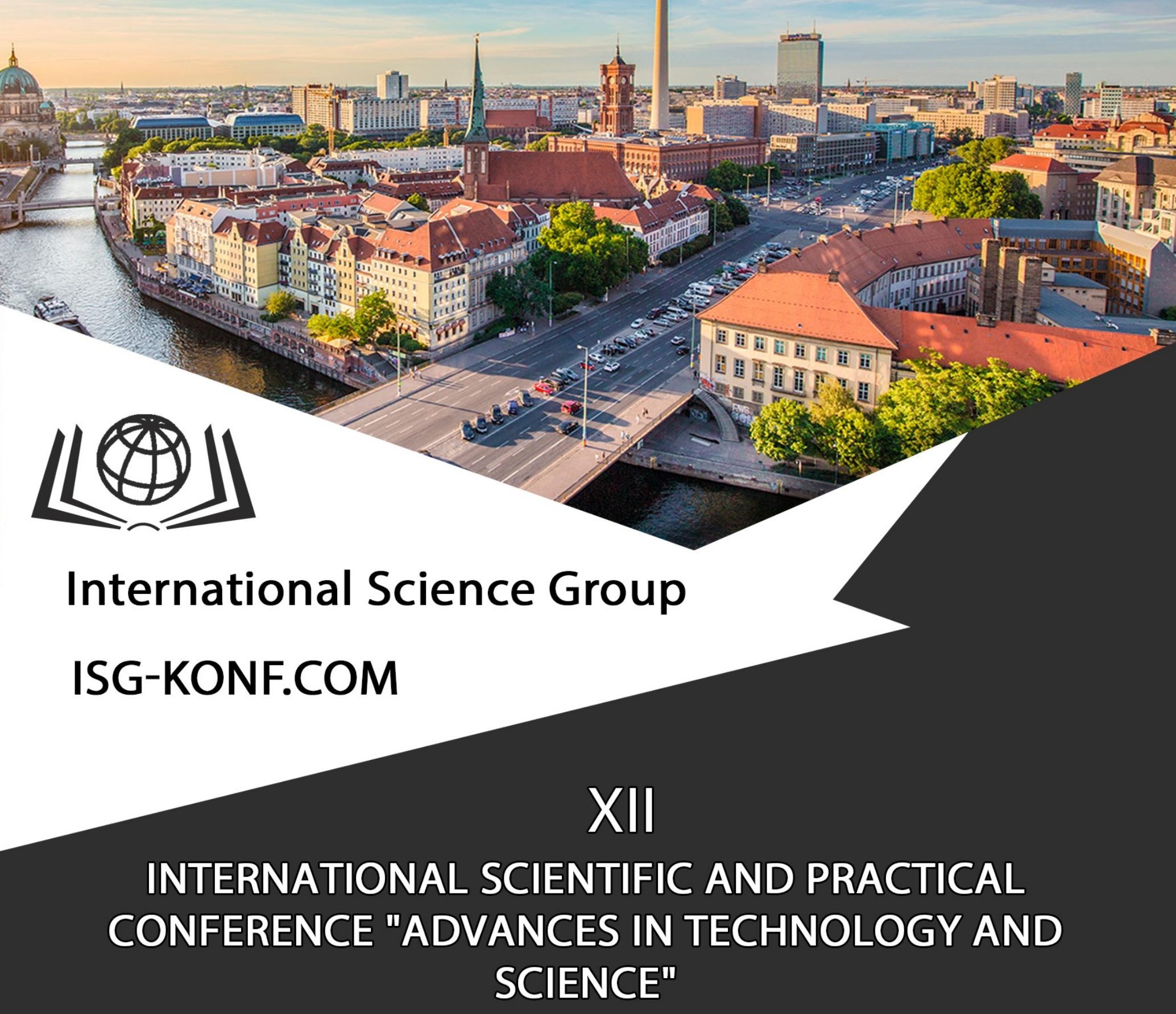




\title{
ADVANCES IN TECHNOLOGY AND SCIENCE
}

Abstracts of XII International Scientific and Practical Conference

\author{
Berlin, Germany
}

March $16-19,2021$ 


\section{Library of Congress Cataloging-in-Publication Data}

\section{UDC 01.1}

The XII International Science Conference «Advances in Technology and Science», March 16-19, 2021, Berlin, Germany. 294 p.

ISBN - 978-1-63732-133-1
DOI - 10.46299/ISG.2021.I.XI I

\section{EDITORIAL BOARD}

\begin{tabular}{|c|c|}
\hline Pluzhnik Elena & $\begin{array}{l}\text { Professor of the Department of Criminal Law and Criminology } \\
\text { Odessa State University of Internal Affairs Candidate of Law, } \\
\text { Associate Professor }\end{array}$ \\
\hline Liubchych Anna & $\begin{array}{l}\text { Scientific and Research Institute of Providing Legal Framework for } \\
\text { the Innovative Development National Academy of Law Sciences of } \\
\text { Ukraine, Kharkiv, Ukraine, Scientific secretary of Institute }\end{array}$ \\
\hline Liudmyla Polyvana & $\begin{array}{l}\text { Department of Accounting and Auditing Kharkiv } \\
\text { National Technical University of Agriculture named after Petr } \\
\text { Vasilenko, Ukraine }\end{array}$ \\
\hline Mushenyk Iryna & $\begin{array}{l}\text { Candidate of Economic Sciences, Associate Professor of } \\
\text { Mathematical Disciplines, Informatics and Modeling. Podolsk State } \\
\text { Agrarian Technical University }\end{array}$ \\
\hline Oleksandra Kovalevska & $\begin{array}{l}\text { Dnipropetrovsk State University of Internal Affairs } \\
\text { Dnipro, Ukraine }\end{array}$ \\
\hline$\underline{\text { Prudka Liudmyla }}$ & $\begin{array}{l}\text { Odessa State University of Internal Affairs, } \\
\text { Associate Professor of Criminology and Psychology Department }\end{array}$ \\
\hline$\underline{\text { Slabkyi Hennadii }}$ & $\begin{array}{l}\text { Doctor of Medical Sciences, Head of the Department of Health } \\
\text { Sciences, Uzhhorod National University. }\end{array}$ \\
\hline Marchenko Dmytro & $\begin{array}{l}\text { Ph.D. in Machine Friction and Wear (Tribology), Associate } \\
\text { Professor of Department of Tractors and Agricultural Machines, } \\
\text { Maintenance and Servicing, Lecturer, Deputy dean on academic } \\
\text { affairs of Engineering and Energy Faculty of Mykolayiv National } \\
\text { Agrarian University (MNAU), Mykolayiv, Ukraine }\end{array}$ \\
\hline Harchenko Roman & $\begin{array}{l}\text { Candidate of Technical Sciences, specialty } 05.22 .20 \text { - operation and } \\
\text { repair of vehicles. }\end{array}$ \\
\hline Belei Svitlana & $\begin{array}{l}\text { Ph.D. (Economics), specialty: } 08.00 .04 \text { "Economics and } \\
\text { management of enterprises (by type of economic activity)" }\end{array}$ \\
\hline
\end{tabular}


TABLE OF CONTENTS

\section{AGRICULTURAL SCIENCES}

\begin{tabular}{|c|c|c|}
\hline 1. & $\begin{array}{l}\text { Vyshnevska L., Sichkar A., Rogalskiy S. } \\
\text { PRODUCTIVITY OF SUGAR BEET HYBRIDS UNDER THE } \\
\text { CONDITIONS OF RIGHT-BANK FOREST-STEPPE OF UKRAINE }\end{array}$ & 11 \\
\hline 2 . & $\begin{array}{l}\text { Галевич О.С. } \\
\text { ПОПУЛЯРИЗАЦІ ТА ВИКОРИСТАННЯ ЗЕЛЕНИХ } \\
\text { ПОКРІВЕЛЬ МІСТА ЛЬВОВА }\end{array}$ & 13 \\
\hline 3. & $\begin{array}{l}\text { ГеЙКО Л.М., ОЛЕшКО О.А., БіТюцЬКИЙ В.С. } \\
\text { ОТРИМАННЯ РИБОПОСАДКОВОГО МАТЕРІАЛУ КОРОПА } \\
\text { ПІДВИЩЕНОЇ ВАГИ З ВИКОРИСТАННЯМ ПРОБІОТИКУ ТА } \\
\text { БІОГЕННОГО НАНОСЕЛЕНУ }\end{array}$ & 15 \\
\hline 4. & $\begin{array}{l}\text { Станкевич С.В. } \\
\text { PAK КАРТОПЛI (SYNCHYTRIUM ENDOBIOTICUM } \\
\text { (SCHILBERSKY)) PERCIVAL В УKPAÏHI }\end{array}$ & 19 \\
\hline 5. & $\begin{array}{l}\text { Черно О.Д., Савчук О.М. } \\
\text { ВПЛИВ КАЛІЙНИХ ДОБРИВ НА ФОРМУВАННЯ ЯКОСТІ } \\
\text { ЗЕРНА ПШЕНИЦІ ОЗИМОЇ У КОРОТКОРОТАЦІЙНІЙ } \\
\text { ПОЛЬОВІЙ СІВОЗМІНІ }\end{array}$ & 23 \\
\hline \multicolumn{3}{|c|}{ ARCHITECTURE, CONSTRUCTION } \\
\hline 6. & $\begin{array}{l}\text { ПоПерешнюК Н.А. } \\
\text { УПРАВЛЕНИЕ ТЕПЛОВЫМ РЕЖИМОМ ЗДАНИЙ КАК ОДИН } \\
\text { ИЗ СПОСОБОВ ЭНЕРГОСБЕРЕЖЕНИЯ }\end{array}$ & 26 \\
\hline \multicolumn{3}{|c|}{ ART HISTORY } \\
\hline 7. & $\begin{array}{l}\text { БабУнич Ю.І. } \\
\text { МОДЕРНІЗМ У ЛІТЕРАТУРНО-МИСТЕЦЬКИХ } \\
\text { КОНЦЕПЦІЯХ: ЗАГАЛЬНОСВРОПЕЙСЬКИЙ ТА } \\
\text { УКРАЇНСЬКИЙ ДОСВІД }\end{array}$ & 30 \\
\hline & BIOLOGICAL SCIENCES & \\
\hline 8. & $\begin{array}{l}\text { Упатова І.П., Стрюкова С.Є. } \\
\text { РЕАЛІЗАЦІЯ ВАЛЕОЛОГІЧНОГО ВИХОВАННЯ У ПРОЦЕСІ } \\
\text { ВИВЧЕННЯ БІОЛОГІЇ }\end{array}$ & 36 \\
\hline
\end{tabular}




\begin{tabular}{|c|c|c|}
\hline \multicolumn{3}{|c|}{ ECONOMIC SCIENCES } \\
\hline 9. & $\begin{array}{l}\text { Tulchinskiy R., Ruzhytskyi A. } \\
\text { BENCHMARKING AS A DIRECTION OF INCREASING THE } \\
\text { COMPETITIVENESS OF THE ENTERPRISE }\end{array}$ & 39 \\
\hline 10. & $\begin{array}{l}\text { Беркун П.С., Шушакова І.К. } \\
\text { ГУДВІЛ В ОБЛІКУ ТА ЗВІТНОСТІ ПІДПРИЄМСТВА }\end{array}$ & 41 \\
\hline 11. & $\begin{array}{l}\text { Бойко Н.В., Заяц О.В. } \\
\text { ОСОБЛИВОСТІ БАНКІВСЬКОГО КРЕДИТУВАННЯ } \\
\text { ТРАНСПОРТНИХ ПІДПРИЄМСТВ НА СУЧАСНОМУ ЕТАПІ }\end{array}$ & 45 \\
\hline 12. & $\begin{array}{l}\text { БУтенко О.П., Чупир О.М., Садовниченко О.В. } \\
\text { ЕФЕКТИВНА СИСТЕМА МЕНЕДЖМЕНТУ ЯКОСТІ ЯК } \\
\text { ВАЖЛИВА СКЛАДОВА УСПІШНОГО ФУНКЦІОНУВАННЯ } \\
\text { ПІДПРИСМСТВА НА БУДІВЕЛЬНОМУ РИНКУ }\end{array}$ & 49 \\
\hline 13. & $\begin{array}{l}\text { Грех А.С. } \\
\text { НАУКОВА ДУМКА ЩОДО ДЕФІНІЦЇ КАТЕГОРІЇ } \\
\text { «ПДПРИЄМНИЦЬКИЙ УНІВЕРСИТЕТ» }\end{array}$ & 53 \\
\hline 14. & $\begin{array}{l}\text { Кислякова К., Метіль Т.К. } \\
\text { ФОРМУВАННЯ КОНКУРЕНТНОЇ СТРАТЕГІЇ ЯК ЗАПОРУКА } \\
\text { ПІДВИЩЕННЯ КОНКУРЕНТОСПРОМОЖНОСТІ } \\
\text { СУЧАСНОГО ПІДПРИЄМСТВА }\end{array}$ & 58 \\
\hline 15. & $\begin{array}{l}\text { Кононенко Л.В., Юрченко О.В. } \\
\text { НЕФІНАНСОВА (СОЦІАЛЬНА) ЗВІТНІСТЬ ПІДПРИЄМСТВ } \\
\text { ТА ЦІЛІ СТАЛОГО РОЗВИТКУ }\end{array}$ & 62 \\
\hline 16. & $\begin{array}{l}\text { Осадча Н.В., ТрУшкіна Н.В. } \\
\text { МОДЕРНІЗАЦІЯ ТРАНСПОРТНОЇ ІНФРАСТРУКТУРИ ЯК } \\
\text { ПРІОРИТЕТ НАЦІОНАЛЬНОЇ ЕКОНОМІКИ НІМЕЧЧИНИ }\end{array}$ & 65 \\
\hline 17. & $\begin{array}{l}\text { Рябова Н.Н. } \\
\text { МОБИЛИЗАЦИЯ СБЕРЕЖЕНИЙ В ИНВЕСТИЦИИ ПУТЕМ } \\
\text { ПАЕВЫХ ИНВЕСТИЦИОННЫХ ФОНДОВ }\end{array}$ & 70 \\
\hline 18. & $\begin{array}{l}\text { Шаровська Т.С., Шерстюк М. } \\
\text { УДОСКОНАЛЕННЯ ОБЛІКУ ВИТРАТ НА ПІДПРИЄМСТВАХ } \\
\text { ОПТОВОЇ ТОРГІВЛІ }\end{array}$ & 74 \\
\hline
\end{tabular}




\begin{tabular}{|c|c|c|}
\hline \multicolumn{3}{|c|}{ GEOGRAPHICAL SCIENCE } \\
\hline 19. & $\begin{array}{l}\text { ГЛУШКОВ А.В., ШаНюК О.В. } \\
\text { ОПТИМІЗАЦІЯ ПОБУДОВИ РАДІОЛОКАЦЙНОГО ПОЛЯ } \\
\text { ІНФОРМАЦІЙНОЇ СИСТЕМИ МОНТТОРИНГУ } \\
\text { НАВКОЛИШНЬОГО СЕРЕДОВИЩА }\end{array}$ & 80 \\
\hline \multicolumn{3}{|c|}{ HISTORICAL SCIENCES } \\
\hline 20. & $\begin{array}{l}\text { Kilochytska T. } \\
\text { FORMATION AND DEVELOPMENT OF THE THEORY OF } \\
\text { DYNAMIC SYSTEMS (1930-1960S) }\end{array}$ & 83 \\
\hline \multicolumn{3}{|c|}{ JOURNALISM } \\
\hline 21. & $\begin{array}{l}\text { Ус Т.І., Малюта В.О. } \\
\text { НЕТОЛЕРАНТНА ЛЕКСИКА В ЗАСОБАХ МАСОВОЇ } \\
\text { КОМУНІКАЦІЇ }\end{array}$ & 87 \\
\hline \multicolumn{3}{|c|}{ LEGAL SCIENCES } \\
\hline 22. & $\begin{array}{l}\text { Каверіна В.В., Мілімко Л.В. } \\
\text { РОЗВИТОК КОНКУРЕНТНОГО ЗАКОНОДАВСТВА УКРАЇНИ } \\
\text { В УМОВАХ ЄВРОПЕЙСЬКОЇ ІНТЕГРАЦІІ }\end{array}$ & 94 \\
\hline 23. & $\begin{array}{l}\text { МельнИк В.С., Мілімко Л.В. } \\
\text { ПРОБЛЕМИ ЗАХИСТУ ПРАВ СУБ’ЄКТІВ } \\
\text { ГОСПОДАРЮВАННЯ }\end{array}$ & 98 \\
\hline \multicolumn{3}{|c|}{ MANAGEMENT, MARKETING } \\
\hline 24. & $\begin{array}{l}\text { Бортников С.Г., БадЛо Н. } \\
\text { РЕКЛАМА В ГОТЕЛЬНО-РЕСТОРАННІЙ СПРАВІ ЯК } \\
\text { ІНСТРУМЕНТ ПРОСУВАННЯ ПОСЛУГ }\end{array}$ & 101 \\
\hline 25. & $\begin{array}{l}\text { Юшкіна О.М. } \\
\text { ПЕРСПЕКТИВНЕ ПЛАНУВАННЯ ІННОВАЦІЙНОГО } \\
\text { РОЗВИТКУ ЗАКЛАДУ ЗАГАЛЬНОЇ СЕРЕДНЬОЇ ОСВІТИ }\end{array}$ & 104 \\
\hline \multicolumn{3}{|c|}{ MEDICAL SCIENCES } \\
\hline 26. & $\begin{array}{l}\text { Barannyk S., Ekhalov V., Barannik C. } \\
\text { PERIOPERATIVE KORREKTUR VON } \\
\text { BLUTFLUSSSTÖRUNGEN BEI PATIENTEN MIT EINSEITIGEM } \\
\text { PATHOLOGISCHEN NIERENHEBEL UND IHRER } \\
\text { REHABILITATION IM POST-OPERATOR }\end{array}$ & 110 \\
\hline
\end{tabular}




\begin{tabular}{|c|c|c|}
\hline 27. & $\begin{array}{l}\text { Єрназарова Я.Я. } \\
\text { ВІКОВІ ОСОБЛИВОСТІ ПАЦІЕНТІВ } 3 \text { ХВОРОБАМИ ЦНС ТА } \\
\text { СПЕЦИФІКА РОБОТИ ФАХІВЦЯ } 3 \text { ФІЗИЧНОЇ ТЕРАПІЇ } 3 \\
\text { РІЗНИМИ ВІКОВИМИ ГРУПАМИ }\end{array}$ & 116 \\
\hline 28. & $\begin{array}{l}\text { КЛИмова Е., Кордон Т., Дроздова Л. } \\
\text { ЦИТОКИНОВЫЙ ДИСБАЛАНС И ИММУНОРЕАКТИВНОСТЬ } \\
\text { НЕКОТОРЫХ СУБПОПУЛЯЦИЙ ЛИМФОЦИТОВ ПРИ } \\
\text { ГЕПАТОСПЛЕНОМЕГАЛИИ РАЗЛИЧНОЙ ЭТИОЛОГИИ }\end{array}$ & 120 \\
\hline 29. & $\begin{array}{l}\text { Курташ Н.Я., Кравчук І.В., Ласитчук О.М. } \\
\text { ПЕРЕБІГ ВАГІТНОСТІ НА ФОНІ РОЗСІЯНОГО СКЛЕРОЗУ } \\
\text { (ОГЛЯД ЛІТЕРАТУРИ) }\end{array}$ & 124 \\
\hline 30. & $\begin{array}{l}\text { Сорочан П.П., Кузьменко О.В., Прохач Н.Е. } \\
\text { МЕТАБОЛІЧНІ ТА ГЕМАТОЛОГІЧНІ РОЗЛАДИ У ХВОРИХ } \\
\text { НА РАК ГРУДНОЇ ЗАЛОЗИ }\end{array}$ & 130 \\
\hline 31. & $\begin{array}{l}\text { УЛЬяницька Н.Я., Ребрик Ю.Ю. } \\
\text { ОСОБЛИВОСТІ ЗАСТОСУВАННЯ ТРАНСКРАНІАЛЬНОЇ } \\
\text { МІКРОПОЛЯРИЗАЦІІ ГОЛОВНОГО МОЗКУ В ПРОГРАМІ } \\
\text { РЕАБІЛІТАЦЇ }\end{array}$ & 133 \\
\hline \multicolumn{3}{|c|}{ PEDAGOGICAL SCIENCES } \\
\hline 32. & $\begin{array}{l}\text { Artemenko D., Artemenko O. } \\
\text { METHODOLOGY OF IMPROVING EFFICIENCY OF SPATIAL } \\
\text { AWARENESS FORMATION OF HIGER EDUCATION } \\
\text { APPLICANTS DURING THE BASIC COURSE }\end{array}$ & 136 \\
\hline 33. & $\begin{array}{l}\text { Bartienieva I., Nozdrova O. } \\
\text { USE OF GAME TECHNOLOGIES IN THE PROCESS OF } \\
\text { FORMATION OF PEDAGOGICAL CREATIVITY OF FUTURE } \\
\text { TEACHERS OF ART DISCIPLINES }\end{array}$ & 141 \\
\hline 34. & $\begin{array}{l}\text { Buchynska T. } \\
\text { THE DEVELOPMENT OF SOFT SKILLS IN THE CONTEXT OF } \\
\text { TEACHING FOREIGN LANGUAGES }\end{array}$ & 145 \\
\hline 35. & $\begin{array}{l}\text { Golub T. } \\
\text { DIGITAL DIDACTICS: AIM, PRINCIPLES, ASSESSMENT }\end{array}$ & 147 \\
\hline
\end{tabular}




\begin{tabular}{|c|c|c|}
\hline 36. & $\begin{array}{l}\text { Ohrimenko Z. } \\
\text { EDUCATIONAL TECHNOLOGY IN VOCATIONAL GUIDANCE } \\
\text { OF SENIOR SCHOOL STUDENTS AS A CONDITION OF } \\
\text { EFFECTIVE VOCATIONAL SELF-DETERMINATION }\end{array}$ & 150 \\
\hline 37. & $\begin{array}{l}\text { Zablotska L., Meleshchenko V., Chernii L. } \\
\text { VIRTUAL CLASSES IN DISTANCE LEARNING FOREING } \\
\text { LANGUAGES FOR SPECIFIC PURPOSES }\end{array}$ & 154 \\
\hline 38. & $\begin{array}{l}\text { Бубнов І.В. } \\
\text { ДЕЯКІ ПИТАННЯ ЯКОСТІ ОСВІТИ ПІД ЧАС } \\
\text { ДИСТАНЦІЙНОГО НАВЧАННЯ }\end{array}$ & 158 \\
\hline 39. & $\begin{array}{l}\text { Годлевська Н.А., Старовєр А.В. } \\
\text { ПРОБЛЕМИ НАВЧАННЯ В ПЕРІОД ПАНДЕМІЇ У ВИЩІЙ } \\
\text { ШКОЛІ }\end{array}$ & 162 \\
\hline 40. & $\begin{array}{l}\text { Гончарук В.В., Гончарук В.А., Подзерей Р.В. } \\
\text { ОСОБЛИВОСТІ ОРГАНІЗАЦІЇ ДИСТАНЦІЙНОГО } \\
\text { НАВЧАННЯ ЗДОБУВАЧІВ ВИЩОЇ ОСВІТИ }\end{array}$ & 165 \\
\hline 41. & $\begin{array}{l}\text { Журба Т.А. } \\
\text { ПРОБЛЕМИ ФОРМУВАННЯ ПИСЕМНОГО МОВЛЕННЯ У } \\
\text { ДІТЕЙ ІЗ ТЯЖКИМИ ВАДАМИ МОВЛЕННЯ }\end{array}$ & 170 \\
\hline 42. & $\begin{array}{l}\text { Здіховська Т.В., Свиріпа І.А. } \\
\text { ТЕОРЕТИЧНІ ОСНОВИ РОЗУМІННЯ ПОНЯТТЯ } \\
\text { ФОЛЬКЛОРНОГО СИМВОЛУ В ПОЧАТКОВІЙ ШКОЛІ }\end{array}$ & 174 \\
\hline 43. & $\begin{array}{l}\text { Оріакхі С.О. } \\
\text { УКРАЇНСЬКА ШКОЛА ТА ІНКЛЮЗИВНА ОСВІТА }\end{array}$ & 179 \\
\hline 44. & $\begin{array}{l}\text { Радзієвська І.В. } \\
\text { ОСОБЛИВОСТІ ЗАБЕЗПЕЧЕННЯ ЯКОСТІ МЕДИЧНОЇ } \\
\text { ОСВІТИ }\end{array}$ & 181 \\
\hline 45. & $\begin{array}{l}\text { Суліцький В.В., Іванів С.А. } \\
\text { СОЦІАЛЬНО-ПЕДАГОГІЧНА РОБОТА ПРАЦІВНИКІВ } \\
\text { ОРГАНІВ ПРОБАЦІЇ ЩОДО ВИПРАВЛЕННЯ ТА } \\
\text { РЕСОЦІАЛІЗАЦЇ ЗАСУДЖЕНИХ }\end{array}$ & 185 \\
\hline
\end{tabular}




\begin{tabular}{|c|c|c|}
\hline 46. & $\begin{array}{l}\text { Яренчук Л.Г. } \\
\text { ДИСТАНЦІЙНЕ НАВЧАННЯ В СИСТЕМІ СУЧАСНОЇ } \\
\text { ШКІЛЬНОЇ ОСВІТИ }\end{array}$ & 190 \\
\hline \multicolumn{3}{|c|}{ PHILOLOGICAL SCIENCES } \\
\hline 47. & $\begin{array}{l}\text { Григоров С.С. } \\
\text { ОСНОВНІ ПРИНЦИПИ РЕКЛАМНОГО ТЕКСТУ }\end{array}$ & 197 \\
\hline 48. & $\begin{array}{l}\text { Павельева А.К. } \\
\text { К ВОПРОСУ О ХРОНОТОПАХ В ПОВЕСТИ Н. В. ГОГОЛЯ } \\
\text { «МАЙСКАЯ НОЧЬ, ИЛИ УТОПЛЕННИЦА» }\end{array}$ & 199 \\
\hline 49. & $\begin{array}{l}\text { Пиц Т. } \\
\text { НАЗВИ РЕМІСНИКІВ ТЕКСТИЛЬНОГО РЕМЕСЛА У } \\
\text { СХІДНИХ НІМЕЦЬКИХ ДІАЛЕКТАХ ХІV-ХVІІ СТОЛІТЬ }\end{array}$ & 205 \\
\hline 50. & $\begin{array}{l}\text { Савчук Р.Л. } \\
\text { АТРАКТИВНА ФУНКЦІЯ ДІАЛЕКТИЗМІВ У } \\
\text { ЗАГОЛОВКОВИХ КОМПЛЕКСАХ СУЧАСНИХ ІНТЕРНЕТ- } \\
\text { ЗМІ }\end{array}$ & 208 \\
\hline 51. & $\begin{array}{l}\text { Shcherbakov Y. } \\
\text { ДО ПИТАННЯ САНСКРИТСЬКОГО ПОХОДЖЕННЯ } \\
\text { ЮАНСЬКОЇ ДРАМИ ЦЗАЦЗЮЙ }\end{array}$ & 211 \\
\hline \multicolumn{3}{|c|}{ PHYSICAL AND MATHEMATICAL SCIENCES } \\
\hline 52. & $\begin{array}{l}\text { Solovei O. } \\
\text { FIBONACCI SEARCH METHOD TO SELECT LEARNING RATE } \\
\text { FOR GRADIENT DESCENT OPTIMIZATION ALGORITHM }\end{array}$ & 214 \\
\hline \multicolumn{3}{|c|}{ POLITICAL SCIENCE } \\
\hline 53. & $\begin{array}{l}\text { Andrushko V. } \\
\text { IS POLITICAL POWER CONFLICTUAL OR CONSENSUAL? }\end{array}$ & 219 \\
\hline 54. & $\begin{array}{l}\text { Shubitidze V., Davitashvili O., Japharidze E. } \\
\text { GEORGIEN IM ÖSTLICHEN PARTNERSCHAFTSSYSTEM }\end{array}$ & 222 \\
\hline 55. & $\begin{array}{l}\text { Тихомирова Є. } \\
\text { СОЦІАЛЬНА ІНЖЕНЕРІЯ }\end{array}$ & 225 \\
\hline
\end{tabular}




\begin{tabular}{|c|c|c|}
\hline \multicolumn{3}{|c|}{ PSYCHOLOGICAL SCIENCES } \\
\hline 56. & $\begin{array}{l}\text { Lavrinenko V. } \\
\text { SOME TOPICAL ISSUES OF PSYCHOLOGICAL SCIENCE } \\
\text { METHODOLOGY }\end{array}$ & 229 \\
\hline 57. & $\begin{array}{l}\text { Гречин Н.Т. } \\
\text { ПОТЕНЦІЙНІ РИЗИКИ РАННЬОЇ ВАГІТНОСТІ }\end{array}$ & 233 \\
\hline 58. & $\begin{array}{l}\text { Терлецька Ю.М. } \\
\text { АНАЛІЗ СОЦІАЛЬНО-ПСИХОЛОГІЧНОЇ ТА СОЦІОЛОГІЧНОЇ } \\
\text { ТЕОРІЙ ПСИХІЧНОЇ ДЕПРИВАЦІЇ }\end{array}$ & 236 \\
\hline 59. & $\begin{array}{l}\text { Федик О.В. } \\
\text { МОРАЛЬНА СВІДОМІСТЬ ТА СЕКСУАЛЬНА ПОВЕДІНКА } \\
\text { МОЛОДІ }\end{array}$ & 240 \\
\hline \multicolumn{3}{|c|}{ TECHNICAL SCIENCES } \\
\hline 60. & $\begin{array}{l}\text { Кавин С. Я., Кавин Я.М., Кавин О. М. } \\
\text { ОСОБЛИВОСТІ ВИКОРИСТАННЯ ВІРТУАЛЬНИХ } \\
\text { ЛАБОРАТОРІЙ В НАВЧАЛЬНО-ОСВІТНЬОМУ } \\
\text { ІНФОРМАЦІЙНОМУ ПРОСТОРІ }\end{array}$ & 243 \\
\hline 61. & $\begin{array}{l}\text { Huz E. } \\
\text { INCREASING THE CARRYING CAPACITY OF THE PRESSING } \\
\text { MECHANISM OF THE ROLLING STATE }\end{array}$ & 246 \\
\hline 62. & $\begin{array}{l}\text { Karmazin M. } \\
\text { WAYS TO INCREASE THE RELIABILITY OF THE BALANCING } \\
\text { DEVICE OF THE ROLLING MILL DRIVE }\end{array}$ & 248 \\
\hline 63. & $\begin{array}{l}\text { Khoma Y., Brydinskyi V., Artemuk S. } \\
\text { APPLICATION OF DEEP LEARNING TECHNOLOGIES FOR } \\
\text { BIOSIGNAL PROCESSING }\end{array}$ & 250 \\
\hline 64. & $\begin{array}{l}\text { Ігнатов А.О., Шипунов С.О., Кононов М.І. } \\
\text { ВИКОНАННЯ БУРОВИХ І ЕКСПЛУАТАЦІЙНИХ РОБІТ ПРИ } \\
\text { СПОРУДЖЕННІ СВЕРДЛОВИН ГІДРАВЛІЧНОГО } \\
\text { РУЙНУВАННЯ І ТРАНСПОРТУВАННЯ }\end{array}$ & 254 \\
\hline 65. & $\begin{array}{l}\text { Аль-Амморі А., Дяченко П.В., Хафед І.С. } \\
\text { АСПЕКТИ ФОРМУВАННЯ СПЕКТРІВ ЧАСТОТ ВЛАСНИХ } \\
\text { КОЛИВАНЬ ЗУБЧАСТИХ ПЕРЕДАЧ }\end{array}$ & 260 \\
\hline
\end{tabular}




\begin{tabular}{|c|c|c|}
\hline 66. & $\begin{array}{l}\text { Басараб І.М. } \\
\text { ОБЛІПИХА - ФУНКЦІОНАЛЬНИЙ ІНГРЕДІЄНТ ПРИ } \\
\text { ВИГОТОВЛЕННІ ВАРЕНИХ КОВБАСНИХ ВИРОБІВ }\end{array}$ & 265 \\
\hline 67. & $\begin{array}{l}\text { Борисова Н.В., Кочуєва З.А., Плєхова Г.А. } \\
\text { ВИЗНАЧЕННЯ ВИМОГ ДО ОНЛАЙН СИСТЕМИ } \\
\text { АДАПТИВНОГО ТЕСТУВАННЯ ЗНАНЬ СТУДЕНТІВ }\end{array}$ & 269 \\
\hline 68. & $\begin{array}{l}\text { Гулієва Н., Пастернак В., Самчук Л. } \\
\text { ОСОБЛИВОСТІ РОБОТИ ГІДРОЦИЛІНДРА ЗАХВАТНОГО } \\
\text { ОРГАНУ }\end{array}$ & 271 \\
\hline 69. & $\begin{array}{l}\text { Кравцов В.І. } \\
\text { НАПРУЖЕНО-ДЕФОРМОВАНИЙ СТАН ОБОЛОНОК } \\
\text { РАКЕТНИХ КОНСТРУКЦЙ }\end{array}$ & 273 \\
\hline 70. & $\begin{array}{l}\text { Крепич С.Я., СПівак І.Я. } \\
\text { ЗАСОБИ ОБЧИСЛЕНЬ ДЛЯ ВЕБ-ОРІЄНТОВАНИХ СИСТЕМ } \\
\text { ЕЛЕКТРОННОЇ КОМЕРЦІІ }\end{array}$ & 277 \\
\hline 71. & $\begin{array}{l}\text { Нурадинов А.С., Кондратьев Ю.И., Нурадинов И.А. } \\
\text { ВАЛКОВАЯ РАЗЛИВКА-ПРОКАТКА АЛЮМИНИЕВЫХ } \\
\text { СПЛАВОВ }\end{array}$ & 283 \\
\hline 72. & $\begin{array}{l}\text { ФарзаЛиев Э.Б., Голубев В.Н. } \\
\text { ХИМИКО-ТЕХНОЛОГИЧЕСКИЕ ОСОБЕННОСТИ } \\
\text { ПЕКТИНОВЫХ ВЕЩЕСТВ ДИКОРАСТУЩЕЙ МУШМУЛЫ } \\
\text { (MESPILUS GERMANICA L.) АЗЕРБАЙДЖАНА }\end{array}$ & 289 \\
\hline
\end{tabular}




\section{PRODUCTIVITY OF SUGAR BEET HYBRIDS UNDER THE CONDITIONS OF RIGHT-BANK FOREST-STEPPE OF UKRAINE}

Vyshnevska Lesya Candidate of Agricultural Sciences, Associate professor Department of plant-grower Uman National University of Horticulture

Sichkar Andriy Candidate of Agricultural Sciences, Associate professor Department of plant-grower Uman National University of Horticulture

Rogalskiy Sergey Candidate of Agricultural Sciences, Associate professor Department of plant-grower Uman National University of Horticulture

Research methodology. Under these conditions, it is important to investigate the growth and productivity of different hybrids of sugar beet after organic nourish sources. Therefore, the growth and yield of different sugar beet hybrids were investigated in crop rotation, where all crops are grown by nutrients of organic mass of sideline products of preceding crops, green-manured fallow and postharvest green manuring [1].

Analysis of the nutrition balance in the crop rotation shows that nitrogen, phosphorus and potassium in the soil layer of $0-60 \mathrm{~cm}$ is sufficient for implementation of the yield of water, which is obtained by crops, due to the precipitation and constant deposits of moisture in the lower soil layers $(0-150-200 \mathrm{~cm})$.

Results of the investigations. Hybrids of sugar beet were grown in the third field of six-field crop rotation. The preceding crop was winter wheat, which was grown on greenmanured fallow. The amount of nitrogen after tillage of green manure crop in the soil layer of 0-40 cm (top + root mass) is 300-340 kg/ha, phosphorus 65-80, potassium 180-220 kg/ha. We don't calculate the nitrogen that leave in the soil, nodule-forming and associative bacteria. There are other sources of nitrogen. Wheat except of yield in crop rotation 60-65 hwt/ha, makes with grain 140-160 kg/ha, phosphorus 56-64, potassium 90-120 kg/ha. Nutrient status of sugar beet was sufficiently high. It is important to note, because the majority of farms that cultivate sugar beets on small areas due to the lack of funds does 
not have the possibility to use heavy rates of fertilizers. Such farms should use the optimum variants of organic and biological technologies broader, they need such hybrids of sugar beet, which would more fully use this organic background and natural potential of Ukrainian soil and would respond to the application of certain elements of modern technology of cultivation of this crop.

As a result of previous researches at the Department of Plant Growing of Uman NUH was used such optimized variant of technology of sugar beet growing: primary soil tillage consisted of wheat stubble ploughing with shredded straw by the disk harrow [2]. The first tillage was carried out on the day of harvesting preceding crop, the second - after the germination of weeds. Plowing was done by plough with coulter on the depth of $24-26 \mathrm{~cm}$. In autumn plough-land was aligned by cultivator.

During the vegetation, the determination of dynamics of root mass accumulation and sugar content of roots was conducted.

The most intensive root mass accumulation during this period was observed in hybrids Bilotserkivskyy MS - 57-78 g and Shevchenkivskyy - 99 g. Obtained data indicate that these hybrids accumulate mass in the second half of the growing season, which indicates their late maturity. Hybrid Umanskyy MS - 76 should be noted, which has stable increments of root mass regardless of its growing in different years.

The yield of hybrids depends on many factors, both agrotechnical and hereditary. During the creation of equal conditions of growing, genetic potential of hybrids created by domestic breeders is in the forefront.

On average for two years the highest sugar content showed hybrids Umanskyy MS 76 and Slovyanskyy MS - $94-16.2 \%$. The lowest sugar content had hybrid Bilotserkivskyy MS $-57-14.4 \%$. Accordingly, during this period, sugar harvest amounted in hybrid Ukrainskyy MS -70 - 59.2 hwt/ha, Slovyanskyy MS - $94-56.8$, Umanskyy MS -76-57.1 hwt/ha [3].

Conclusion. On the basis of conducted researches we recommend maximally using the hybrids that are adapted to the appropriate growing conditions in Man'kivka Natural Agricultural District. These are hybrids Umanskyy MS - 76, Ukrainskyy MS - 70, Slovyanskyy MS - 94.

\section{References:}

1. Research Methods on Sugar Beet/V.F. Zubenko, L.A. Barshtein, N.G. Hizbullin et al. K. AURIS. 1986. 292 p. (in Ukrainian).

2. Effective Use of Irrigated Lands // Scientific Principles of Agro-Industrial Production in the Steppe of Ukraine. Kyiv. Agrarian Science. 2010. p. 211-238 (in Ukrainian).

3. Vyshnevska L.V., Poltoretskyi S.P. Growth and productivity of sugar beet depending on conditions of mineral nutrition / Bulletin of Uman National University of Horticulture - Uman, 2016. - 48-51 p. 


\section{ПОПУЛЯРИЗАЦЯ ТА ВИКОРИСТАННЯ ЗЕЛЕНИХ ПОКРІВЕЛЬ МІСТА ЛЬВОВА}

\section{Галевич Оксана Свгеніївна}

аспірант кафедри ботаніки, деревинознавства та недеревних ресурсів лісу, Національний лісотехнічний університет України, м. Львів, Україна

Актуальність тематики пов'язана 3 поширенням нових тенденцій в озелененні міст, появою і розвитком садів на дахах в сучасній архітектурі Львова, а також фактом суттєвого покращення екологічної ситуації в місті за рахунок використання пустуючих поверхонь будівель. Ідея озеленення дахів набирає усе більшої популярності, адже зелені насадження відіграють важливу роль в житті та здоров'ї людей, зменшують вплив урбанізації. Розвиток ландшафтного дизайну, удосконалення сучасних технологій і будівельних матеріалів, поява на світовому ринку легких поживних субстратів, що замінюють звичний важкий грунт, вивчення закордонного досвіду - все це дозволяє спеціалістам у галузі озеленення та ландшафтного дизайну в Україні створювати сади на штучних основах швидко та якісно.

Основною метою створення зелених дахів в місті Львові $є$ доцільне та раціональне використання простору в середовищі, що дуже швидко розбудовується, формування міських зелених дахів як функціонально обгрунтованого, зручного в експлуатації середовища.

Досліджено, що для створення зеленого даху потрібно особливо чітко обдумати систему дренажу грунту, способи захисту рослин від механічного ушкодження та переохолодження під впливом вітру, забезпечити підвищення гідроізоляції покрівлі, провести колористичний аналіз для елементів зелених дахів; організувати систему поливу i водовідводу, а також забезпечити безпечний рух по даху будівлі, визначити здатність даху витримувати додаткове навантаження: вагу родючого грунту, різноманітного обладнання, декоративних елементів, рослин.

Створення зелених дахів на покрівлях будинків, офісів, торгових центів, державних установ дозволять збільшити зелені масиви, що призведе до покращення екологічної, естетичної ситуації у Львові. I, справді початок покладений, адже у місті Львові з'явилась перша зелена зупинка, яка стане справжній оазисом в спекотні дні міста та надасть ій привабливого вигляду. Адже, дерева допомагають очищувати повітря від забруднення його машинами на жвавих прилеглих вулицях, поглинаючи близько 200000 літрів викидів $\mathrm{CO}_{2}$. При зміні сезонів, листя дає відмінну тінь під час літньої спеки, і дозволяє сонячним променям вільно проникати взимку, створюючи мікроклімат будівлі.

Зелені дахи скорочують: витрати на електроенергію, кондиціонування та опалення; обслуговування і ремонт даху; ефект теплового острова (в будинку під зеленою покрівлею буде тепло взимку і прохолодно влітку), потоки води, що стікають $з$ дахів під час сильних дощів; збільшують: термін служби даху; звукоізоляцію (знижують шумовий фон у внутрішніх приміщеннях, що важливо 
для мешканців будинків, розташованих біля «галасливих» автомагістралей); покращують: якість повітря (рослини поглинають і перетворюють вуглекислий газ і вивільнюють кисень); естетичність незвичайного ландшафту; економлять простір і компенсують природі площі, яка була зайнята при будівництві будинку.

Остаточні результати дослідження показують, що зелені дахи мають важливу роль в поліпшенні якості міського середовища 3 точки зору стійкої архітектури. Основними проблемами для розвитку зелених дахів в містах можна віднести відсутність достатнього знання про користь зелених дахів, відсутність мотивації в державних і приватних секцій, економічні бар'єри, пов'язані 3 витратами на зелені дахи, відсутність знання довгострокових економічних вигод зелених дахів і відсутність згоди ймовірних ризиків через невизначеність в деяких технічних проблем і нових технологій зелених дахів. Таким чином, передбачається, що дослідження має бути зроблено, щоб ідентифікувати і розвивати зелені дахи. Крім того, деякі плани будуть планується створити дешеві зелені дахи, надаючи фінансові кошти, щоб мотивувати інвесторів вкладати кошти в зелені дахи. Крім того, деякі рекламні оголошення повинні бути розроблені про важливість зелених дахів в міський якості навколишнього середовища і необхідність участі всіх людей, які перебувають в експлуатації цих планів з боку державних засобів масової інформації. Муніципалітети можуть відігравати важливу роль у цій галузі, представивши необхідне обладнання і засоби розвитку зелених дахів для інвесторів і людей.

Отже, в сучасних умовах дефіциту міських територій та озеленених просторів необхідно проектувати дах як один 3 головних планувальних компонентів будівлі. Тому екологічний ефект садів на дахах дуже суттєвий. В України все попереду, але початок уже покладено.

\section{Список літератури:}

1. Веинский А. М. Сады на крыше // Экология и жизнь. -2010 . - № 10. - C. 68-73.

2. Голлвитцер Г., Вирсинг В. Сады на крышах. - М. : Стройиздат, 1972. $-118 \mathrm{c}$. $456 \mathrm{c}$.

3. Кучерявий В.П. Озеленення населених місць - Львів: Світ, 2008. - 


\title{
ОТРИМАННЯ РИБОПОСАДКОВОГО МАТЕРІАЛУ КОРОПА ПІДВИЩЕНОЇ ВАГИ З ВИКОРИСТАННЯМ ПРОБІОТИКУ ТА БІОГЕННОГО НАНОСЕЛЕНУ
}

\author{
Гейко Леонід Миколайович
}

канд. с.-г. наук

Білоцерківський національний аграрний університет

\section{Олешко Олександр Анатолійович}

канд. с.-г. наук, доцент

Білоцерківський національний аграрний університет

\section{Бітюцький Володимир Семенович}

доктор. с.-г. наук, професор

Білоцерківський національний аграрний університет

Постановка проблеми. Прісноводна аквакультура має великий потенціал в ЄС та інших країнах світу. За прогнозами ФАО до 2050 року очкується збільшення попиту на продукцію аквакультури, оскільки на нашій планеті буде проживати понад 9 млрд. людей. Окрім морської аквакультури, $є$ багато видів прісноводних риб, виробництво яких можна радикально збільшити за рахунок інвестицій, інновацій та створення великої кількості робочих місць в прісноводному секторі [1].

Коропівництво в останні роки в Європі знаходиться у стані стагнації, без суттєвого приросту продуктивності і основними проблемами цього вважаються відсутність ефекту масштабування та скорочення кількості працівників задіяних у виробничих процесах. Більш глибокі дослідження, показали, що не тільки скорочення робочої сили призвели до застою виробничих показників в цьому сегменті аквакультури, але й відсутність суттєвих інвестицій на підтримку та розробку нових технологій, які б стимулювали появу нових робочих місць[2].

Короп - один з найбільш розповсюджених видів прісноводних риб у Східній Європі, який вирощують переважно у ставових господарствах за дво- або трирічним циклом. Отримання коропа відповідної товарної маси в нашій географічній зоні в більш коротші терміни можливе при використанні установок замкнутого постачання, тобто виключення із циклу виробництва холодних періодів року. Але при цьому, важливо правильно оцінити та порівняти енергетичний баланс цих різних технологій вирощування. Іноді продуктивність доволі висока в одних системах та нижча в інших, і з точки зору грошових вкладень може здаватися цілком життєздатною, але при підрахунку енергетичних витрат, може спостерігатися зворотна картина. Наприклад, амортизація витрат для будівництва рибогосподарського ставу буде мінімальною в порівнянні із садком або закритою системою рециркуляції [3]. В 
нашій країні використовувати УЗВ для повного циклу вирощування коропа економічно недоцільно, оскільки собівартість продукції буде дуже високою. Одним із способів скорочення строків на вирощування коропа до товарної маси може бути використання рибопосадкового матеріалу підвищеної ваги.

В Україні за традиційними технологіями пересаджування однорічок коропа iз зимувальних у вирощувальні стави проводять ранньою весною, при низьких температурах. На активне харчування однорічки переходять лише при достатньому прогріванні води, яке як правило відбувається через місяць-півтора. Пересаджування молоді коропа із зимувальних ставів у басейни або садки на певний період, в яких підтримується підвищена температура води і створені умови для ущільнених посадок, надасть змогу отримати однорічок підвищеної маси на початок вегетаційного періоду.

Результати досліджень. В наших дослідженнях ми проводили підрощування рибопосадкового матеріалу в штучних умовах протягом 40 діб, яка передбачала годівлю риби повноцінним гранульованим комбікормом. Але необхідно було враховувати, що при вирощуванні в басейнах, риби постійно знаходяться в умовах стресу, однією 3 найбільш поширених форм якого $\epsilon$ окислювальний стрес [4]. Важливим мікронутрієнтом, який може знижувати негативну дію окислювального стресу є селен. Він входить до складу активних центрів ферментів глуатіонпероксидази i тіоредоксинредуктази, які забезпечують антиоксидантний захист [5,6], а введення до раціону пробіотика позитивно впливає на темпи росту та вміст білку [7]. Тому додавали до комбікорму пробіотик (L.Plantarum) в комплексі із селенітом натрію i наноселеном.

Дослід проводили в басейнах, в яких підтримували однакові стабільні умови протягом 40 діб за допомогою фільтраційних систем, аераторів i терморегуляторів. Температура води підтримувалась на рівні $22^{\circ} \mathrm{C} ; \mathrm{pH}-7-7,2$; вміст розчиненого кисню - 6 мг/л. В якості основного раціону (ОР) використовували збалансований комбікорм для однорічок коропа К-111/2, який призначений як для ставів, так і для годівлі в індустріальних умовах. Контрольну групу годували комбікормом К-111/2. В дослідній групі №1 до основної дієти додавали пробіотик (L.Plantarum); в групі №2 додавали пробіотик (L.Plantarum) + селеніт натрія; в групі №3 - додавали пробіотик (L.Plantarum) + наноселен.

На початку досліду за масою тіла однорічки всіх дослідних груп істотно не відрізнялись, середні значення цього показнику були в межах 17,4-17,6 г. За показниками висоти і довжини тіла також не було істотної різниці (рис 1). 


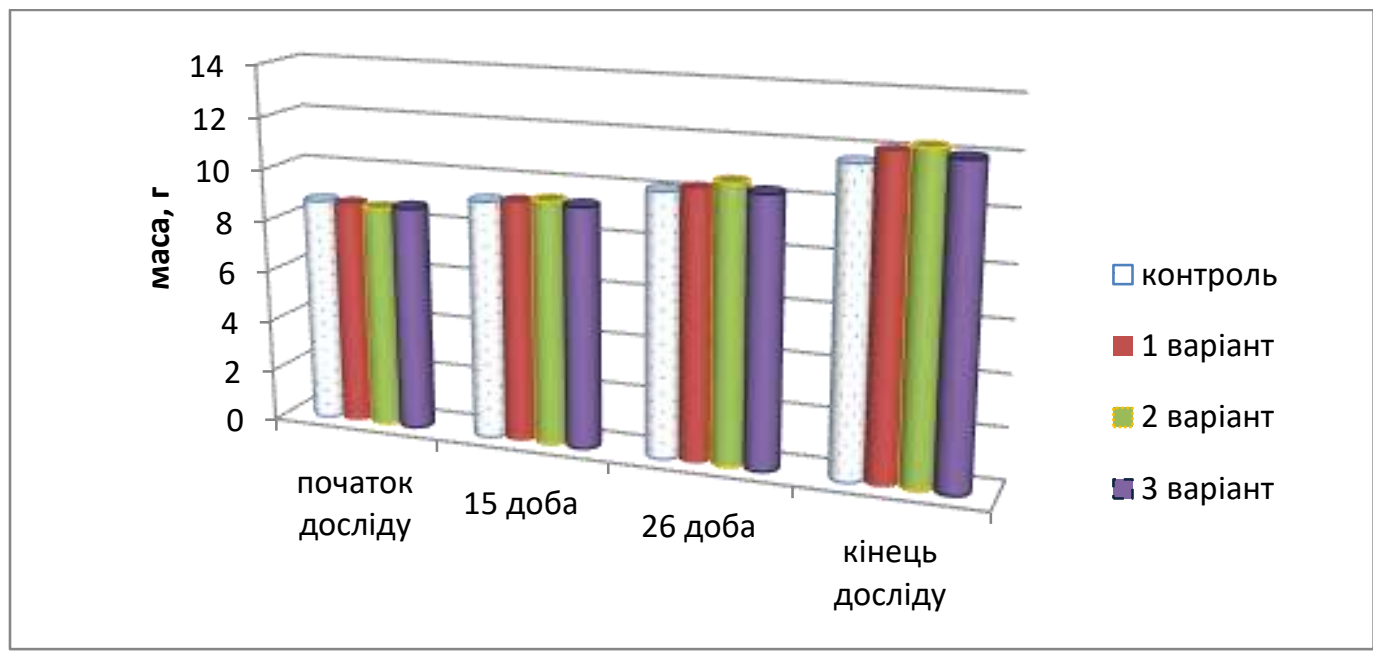

Рис. 1. Динаміка показника «маса тіла» у однорічок коропа в дослідних басейнах

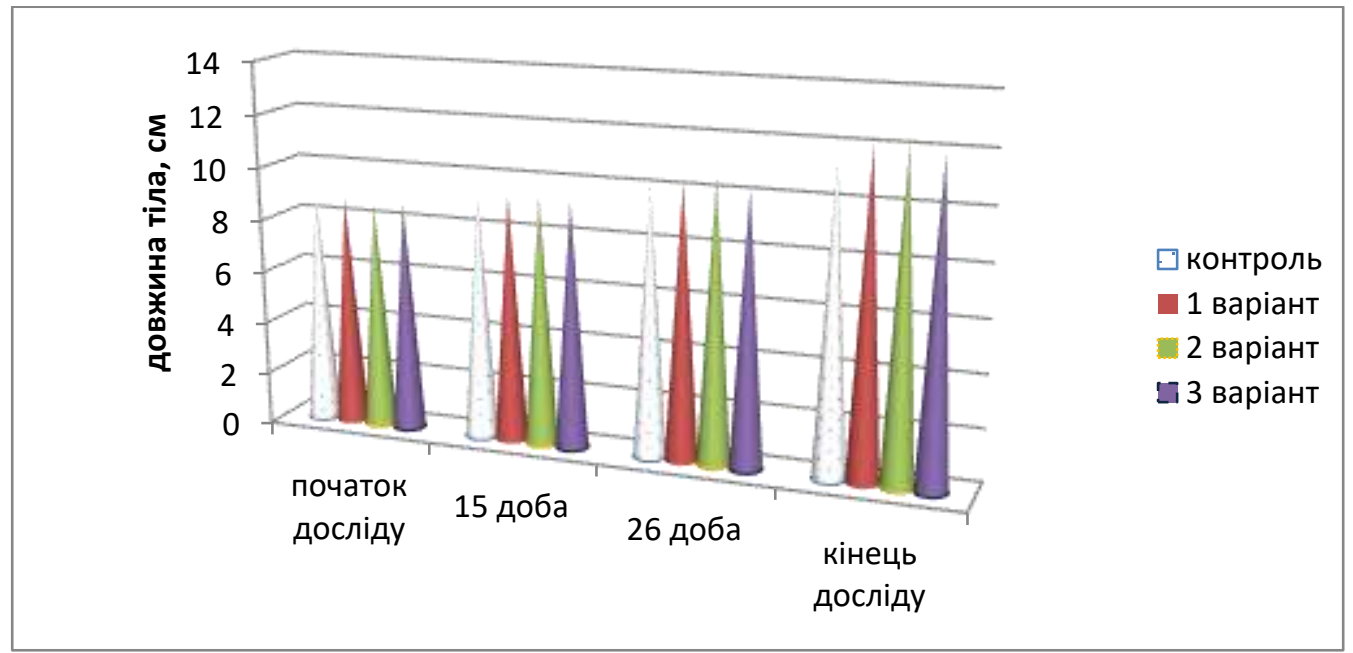

Рис. 2. Рис. 1. Динаміка показника «довжина тіла» у однорічок коропа в дослідних басейнах

На 15 добу досліду результати показали, що найбільші значення приросту спостерігалися в I і II дослідних групах, середні значення показника «маса тіла» становили $30,2 \pm 0,56$ і $31,2 \pm 0,43$ г відповідно. В контрольній групі середня маса була на рівні $28,3 \pm 0,61$ г. Середньоарифметичне значення маси тіла в третій

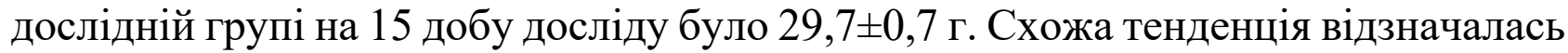
і за показниками довжини і висоти тіла. Найвищі значення були зафіксовані в I і II дослідних групах.

Аналогічні результати можна було спостерігати протягом всього періоду дослідження. Середньостатистичний показник маси тіла в кінці досліду для

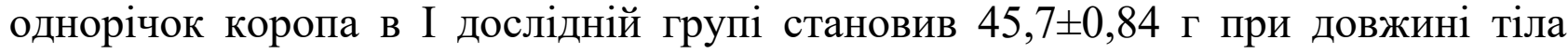
$12,1 \pm 0,11$ см і висоті тіла 4,2 $\pm 0,04$ см. В другій дослідній групі значення цих

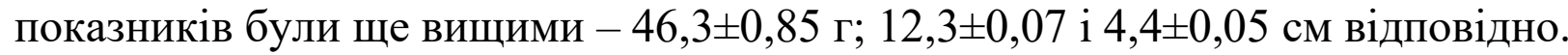

Приріст в контрольній групі за дослідний період склав 21,6 г; в першій 28,1 г; в другій - 28,8 г; в третій - 26,1 г. Тобто, в порівнянні з контрольною групою в усіх варіантах досліду було відзначені більш високі значення вагових і морфометричних показників однорічок коропа. 
Висновки. Таким чином, максимальний позитивний ефект при отриманні рибопосадкового матеріалу коропа підвищеної ваги, спостерігався при введенні до основного раціону пробіотика L.Plantarum в комплексі із селенітом натрія. Дослідні риби, які підрощувались в басейнах на початок вегетаційного періоду перевищували однорічок, які залишилися у вирощувальних ставах, за ваговими та морфо-метричними показниками майже в 2 рази. Це вплинуло на більш високі показники товарної маси піддослідних дволіток при осінньому вилові, вага яких становила в середньому 750 г, а вирощених за традиційною технологією - 450 г.

Використання такої комбінованої технології, при підрощуванні частини рибопосадкового матеріалу коропа після зимівлі в басейнах з контрольованими умовами та запропонованою дієтою, надасть можливість збільшити рибопродуктивність та не вплине на підвищення собівартості продукції.

\section{Список літератури:}

1. Gyalog G, Oláh J, Békefi E, Lukácsik M, Popp J. Constraining Factors in Hungarian Carp Farming: An Econometric Perspective. Sustainability. 2017; 9(11):2111. https://doi.org/10.3390/su9112111

2. Páczay G (2018) Sustainable freshwater aquaculture in the EU and in Hungary. Int J Aquac Fish Sci 4(3): 039-044. DOI: 10.17352/2455-8400.000042

3. J. Olah, V.R.P. Sinha. ENERGY COST IN CARP FARMING SYSTEMS.NACA / WP / 86/35. http://www.fao.org/3/AC225E/AC225E00.ht.

4. Biplab Sarkar, Surajit Bhattacharjee, Akshay Daware, Prosun Tribedi, Krishnani, K. K., \& Minhas, P. S. (2015). Selenium Nanoparticles for Stress-Resilient Fish and Livestock. Nanoscale Research Letters 10:371. doi: 10.1186/s11671-0151073-2.

5. Vítová, M., Bišová, K., Hlavová, M., Zachleder, V., Rucki, M., \& Č́žžková, M. (2011). Glutathione peroxidase activity in the selenium-treated alga Scenedesmus quadricauda. Aquat. Toxicol, 102(1-2), 87-94. doi: 10.1016/j.aquatox.2011.01.003.

6. Mykhailenko, N.F. (2016). Growth and photosynthetic activity of green algae Chlorella vulgaris Beijer in the presence of selenium nanoaquachelates. Microbiology \& Biotechnology, 2(34), 6-15. DOI: http://dx.doi.org/10.18524/23074663.2016.2(34).70746.

7. Abdel TM, Sharafeldin KM, Mosaad MNM, Ismaiel NEM (2015) Coffee bean in common carp, Cyprinus carpio L. diets: Effect on growth performance, biochemical status, and resistance to waterborne zinc toxicity. Aquaculture 207-213. 


\title{
РАК КАРТОПЛI (SYNCHYTRIUM ENDOBIOTICUM (SCHILBERSKY)) PERCIVAL B УKPAÏHI
}

\author{
Станкевич Сергій Володимирович \\ кандидат сільськогосподарських наук, доцент \\ Харківський національний аграрний університет ім. В.В. Докучаєва
}

Збудник захворювання гриб Chrysophlyctis endobiotica Schilbersky, Synchyrium solani Massee. Належить до відділу Chytridiomycota (Хітридієві) класу Chytridiomycetes (Хітридієві) порядку Chytridiales (Хітридіальні) родини Synchytriaceae (Сінхітрієві)

3 культурних рослин збудник уражує лише картоплю. Меншою мірою уражуються інші рослини роду паслін (Solanum) і томат (Lycopersicon). При потраплянні в грунт гриб швидко накопичується й через 2-3 роки уражує велику кількість рослин картоплі. Особливо шкідливий рак на присадибних ділянках, де при беззмінній культурі картоплі й вирощуванні сприятливих сортів він призводить до повної втрати врожаю.

Припускають, що в Свропу гриб було завезено із садивним матеріалом 3 Південної Америки (Перу). Уперше рак картоплі було виявлено й описано в 1888 p. в Австро-Угорщині. Збудник поширений локально майже у всіх країнахчленах СОКЗР. В Україні рак картоплі вперше було виявлено в 1935 р. на присадибній ділянці в м. Славута Хмельницької області. На даний час раком картоплі заражено по Україні: Львівська, Вінницька, Донецька, Житомирська, Закарпатська, Івано-Франківська, Сумська, Чернівецька області.

На сьогодні ареал поширення хвороби у світі є таким: Свропа: Білорусь, Великобританія, Ірландія, Італія, Латвія, Люксембург, Німеччина, Нідерланди, Норвегія, Польща, Румунія, Росія, Словаччина, Словенія, Україна, Фарерські ови, Фінляндія, Чехія, Чорногорія, Швейцарія, Швеція; Азія: Вірменія, Бутан, Грузія, Індія, Китай, Непал, Туреччина; Африка: Алжир, ПАР, Туніс; Північна Америка: Канада; Південна Америка: Болівія, Еквадор, Перу, Фолклендські о-ви; Океанія: Нова Зеландія (рис. 1).

Збудник є внутрішньоклітинним паразитом, який не утворює міцелію. Основне значення в циклі розвитку мають зимові або літні зооспорангії, за допомогою яких гриб зберігається й поширюється в природі навесні; за температури вище $8^{\circ} \mathrm{C}$ зооспорангії проростають, утворюючи 200-300 рухливих одноджгутикових зооспор, які уражують клітини рослини-живителя. Потрапляючи на сприятливу тканину, зооспора розчиняє клітини епідермісу і через отвір, який утворився під впливом збудника, проникає в клітину рослини. Під впливом життєдіяльності збудника уражена клітина збільшується в розмірах, у ній гриб через деякий час розпадається на 5-7 багатоядерних клітин - літніх зооспорангіїв. 


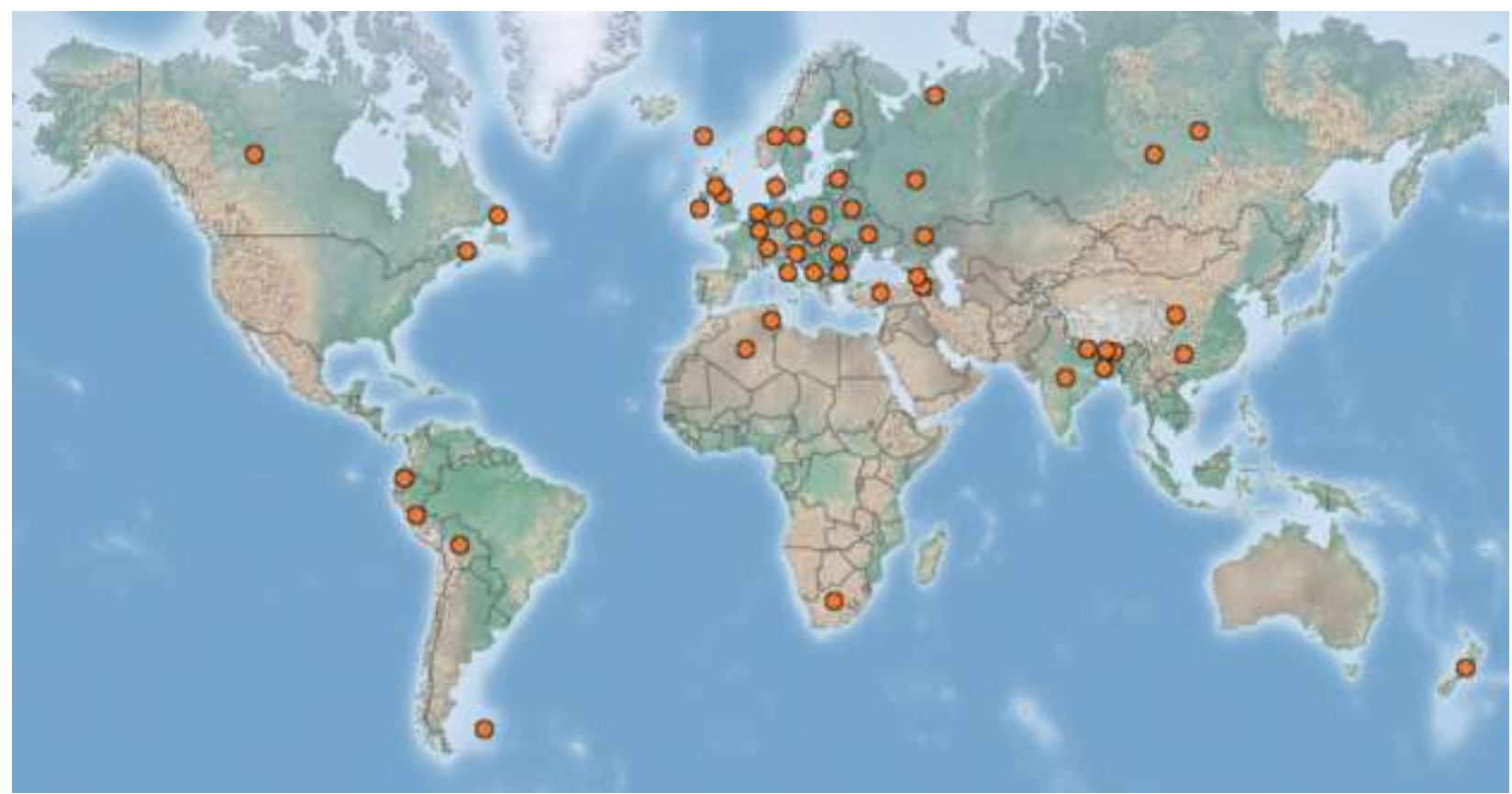

Рис. 1. Світовий ареал Synchytrium endobioticum (Schilbersky) Percival

Зооспори, які утворюються під час їхнього проростання, разом із грунтовою вологою рухаються по капілярах і знову уражують зростаючу тканину картоплі. Цикл розвитку повторюється. На початку осені спостерігається статевий цикл розвитку збудника. При цьому копулюють дві зооспори, які виходять $з$ літніх зооспорангіїв. Формується дводжгутикова зигота, яка під час ураження сприятливої тканини утворює товстостінний зимовий зооспорагій. Зимові зооспорангії, завдяки щільним оболонкам, у стані анабіозу здатні протягом 30 і більше років перебувати в грунті, не втрачаючи здатності до проростання й зараження картоплі. Цикл розвитку раку картоплі триває 12-14 діб і за сприятливих умов відбувається постійно, протягом усього вегетаційного періоду. До кінця вегетації картоплі нарости загнивають, ушкоджуючи здорову частину бульби.

Зимові зооспорангії зазвичай сферичні, діаметром близько 50 мкм (2575 мкм) (рис. 2). Злипаючись із грунтом, вони утворюють грудочки діаметром 0,1-2,0 мм. Зернистий протопласт покритий багатошаровою оболонкою, яка дозволяє добре переносити несприятливі умови для розвитку в зимовий період.

При ураженні картоплі раком утворюються нарости на бульбах (рис. 3), столонах, кореневій шийці, а за значного розвитку захворювання - на стеблі, листках і квітках. За зовнішнім виглядом нарости нагадують плоди цвітної капусти. Розмір наростів буває різним - від дрібної горошини до величини, яка перевищує розмір бульби. Нарости, які формуються в грунті, білого кольору, на надземних частинах рослин - зелені. До закінчення вегетації картоплі нарости темнішають і згнивають. Ракові нарости розвиваються на бульбах і в сховищах, якщо врожай вирощено на зараженій ділянці. Корені картоплі ніколи не уражуються. Потрапляючи на поле, збудник швидко накопичується в грунті й через 2-3 роки уражує більшість рослин картоплі 


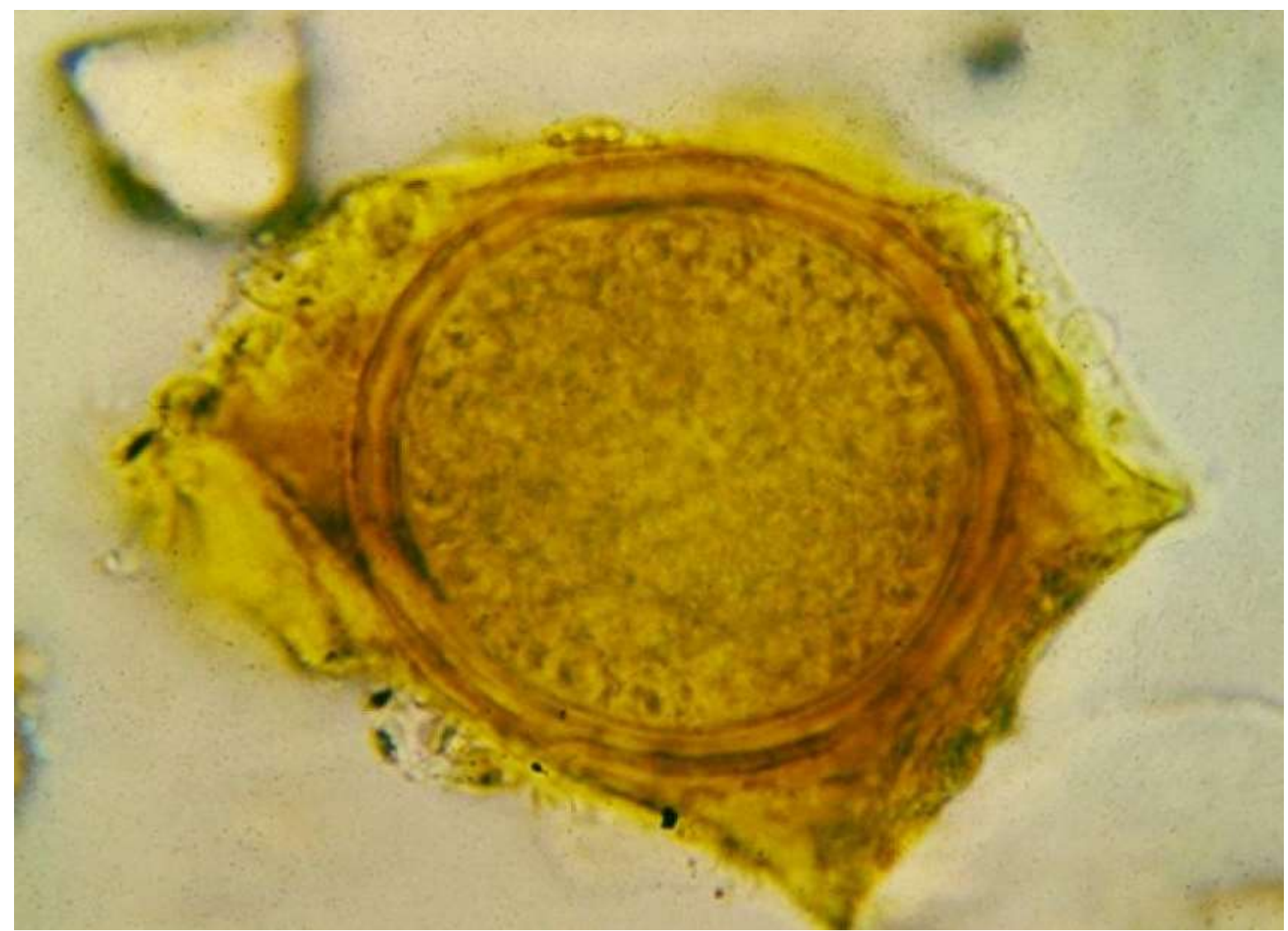

Рис. 2. Зимовий зооспорангій Synchytrium endobioticum (Schilbersky) Percival

Розповсюдження раку картоплі в природних умовах дуже повільне. Найчастіше він поширюється $з$ ураженими бульбами або бульбами нестійких сортів, які мають на своїй поверхні часточки зараженого грунту, а інколи іншим рослинним матеріалом, вирощеним на зараженій ділянці. Знаряддя обробітку грунту, гній і тара також можуть стати причиною появи нового осередка.

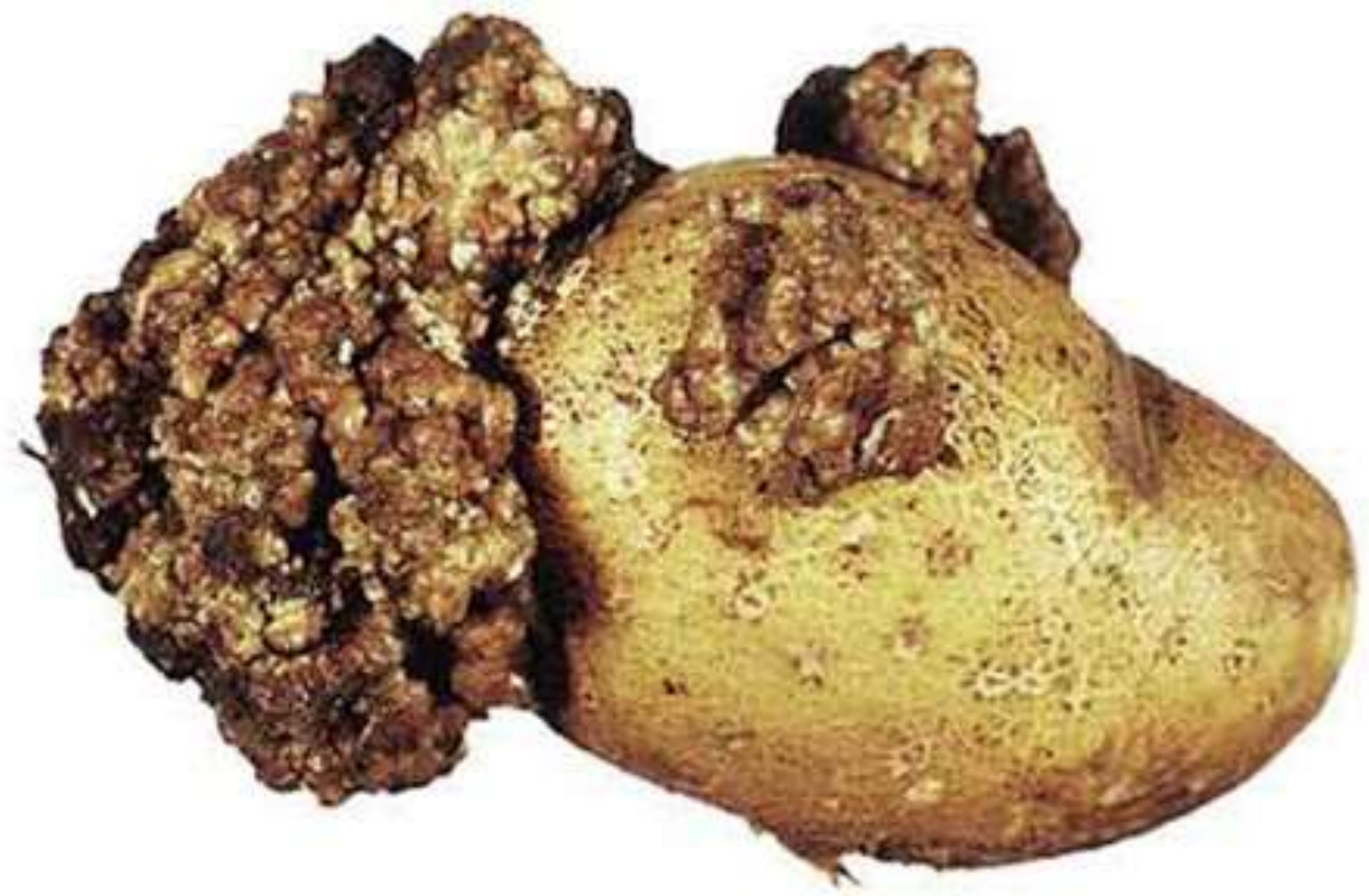

Рис. 3. Бульба картоплі, уражена раком 
Заборонено завезення ураженого садивного матеріалу й грунту з регіонів розповсюдження хвороби. При ввезенні в пунктах пропуску проводять первинне інспектування, з обов'язковим відбиранням зразків для фітосанітарної експертизи, та повторні - у місцях надходження.

В Україні розроблено й застосовують комплексну систему боротьби проти раку картоплі. Вона спрямована на недопущення проникнення захворювання в незаражені райони, на обмеження розповсюдження хвороби й ліквідацію осередків. Основне значення в боротьбі 3 S. endobioticum відводять вирощуванню культур, які не уражуються хворобою та впровадженню ракостійких сортів картоплі (Чернігівська рання, Водограй, Слов'янка, Повінь, Доброчин та ін.). 


\title{
ВПЛИВ КАЛІЙНИХ ДОБРИВ НА ФОРМУВАННЯ ЯКОСТІ ЗЕРНА ПШЕНИЦІ ОЗИМОЇ У КОРОТКОРОТАЦІЙНІЙ ПОЛЬОВІЙ СІВОЗМІНІ
}

\author{
Черно Олена Дмитрівна, \\ кандидат с.-г. наук, доцент \\ Уманський національний університет садівництва
}

Савчук Олег Михайлович, здобувач ступеня вищої освіти магістр факультету агрономії Уманський національний університет садівництва

Продуктивність пшениці озимої залежить від забезпечення рослин елементами мінерального живлення упродовж вегетації. Сучасні інтенсивні сорти характеризуються високими вимогами до умов живлення і лише за повного i збалансованого забезпечення поживними речовинами можуть реалізувати свій генетичний потенціал.

На даний час одностороннє та незбалансоване застосування мінеральних добрив призводить до скорочення вмісту рухомих сполук фосфору і калію у грунті. В результаті за внесення високих доз азоту збільшується ураженість рослин хворобами і шкідниками, знижується ефективність добрив [1-3].

Встановлено, що, чим вища урожайність, тим більший винос поживних речовин. За високих врожаїв рослини пшениці озимої можуть споживати не менше калію, ніж просапні культури при середніх рівнях врожайності. 3 урожаєм 5,0-6,0 т/га 3 грунту виноситься: азоту - 160-190 кг, фосфору - 55-70, калію 140-160 кг.

Калійні добрива, особливо на тлі надмірного азотного живлення, сприяють підвищенню стійкості сільськогосподарських культур проти ураження хворобами і шкідниками [4]. Тому метою наших досліджень стало вивчення впливу калійних добрив на показники якості зерна пшениці озимої.

Дослідження проводили у стаціонарному досліді кафедри агрохімії i грунтознавства Уманського національного університету садівництва, який був закладений у 2010 р. Грунт дослідних ділянок чорнозем опідзолений важкосуглинковий на лесі. В досліді застосовували аміачну селітру, суперфосфат гранульований, калій хлористий. Загальна площа дослідної ділянки 110 м², облікова - 80. Повторність дослідів триразова. Фосфорні і калійні добрива вносили під основний обробіток, а азотні - в підживлення у фазу кущіння та виходу в трубку дозами $\mathrm{N}_{75}+\mathrm{N}_{75}$. За контроль взято варіант, де добрив не вносили.

Якість зерна пшениці озимої є одним з основних ознак, що визначають його вартість на ринку. Вона обумовлюється хімічним складом зерна і залежить від грунтово-кліматичних умов, рівня забезпеченості мінеральним живленням i 
біологічними особливостями сорту [5]. У зерні пшениці налічується більше 48 інгредієнтів (білок, жир, крохмаль, вітамінами, мікроелементи тощо).

Важливими показниками, що визначають якість зерна, є вміст білка i клейковини, маса 1000 зерен і натура зерна.

Встановлено, що добрива впливали на якість зерна пшениці озимої, що розміщувалась після сої. Різні дози і співвідношення добрив у сівозміні змінювали показники якості зерна пшениці озимої. У контрольному варіанті, де добрив не вносили, маса 1000 зерен була найменшою і становила 34,3 г. Сумісне застосування азотних і фосфорних добрив $\left(\mathrm{N}_{150} \mathrm{P}_{60}\right)$ підвищували цей показник на 4,7 г. За внесення калійних добрив дозою $\mathrm{K}_{40}$ на фоні $\mathrm{N}_{150} \mathrm{P}_{60}$ маса 1000 зерен була найвищою і становила 44,2 г. Подальше збільшення дози калійних добрив не призводило до іiі підвищення. Аналогічна закономірність відмічена і щодо натури зерна, але при цьому різниця між варіантами була дещо меншою.

Згідно ДСТУ 3768:2019 у варіанті $\mathrm{N}_{150} \mathrm{P}_{60} \mathrm{~K}_{40}$ за показником натури зерно відповідало 2 класу якості, а в решті варіантів досліду - 3 класу. В роки досліджень між масою 1000 зерен і його натурою встановлено сильну кореляційну залежність $(\mathrm{r}=0,96)$.

На міжнародному ринку одним з головних показників якості зерна пшениці озимої є вміст у ньому білка. Цей показник може варіювати від 6 до 20 \% і від нього залежить не лише поживна цінність, а і вартість зерна.

В усіх варіантах досліду було одержано достовірний приріст його вмісту порівняно з варіантом без добрив. Максимальним він був за внесення $\mathrm{N}_{150} \mathrm{P}_{60} \mathrm{~K}_{40}$. Підвищення калійних добрив до 80 кг/га д.р. на фоні $\mathrm{N}_{150} \mathrm{P}_{60}$ не сприяло збільшенню вмісту білка в зерні пшениці озимої, оскільки значна частина елементів живлення йшла на формування високих врожаїв, що призводило до зниження його білковості. За вмістом білка на ділянках, де добрив не вносили, зерно відповідало 4 класу, а на удобрених варіантах -2 класу якості.

Аналогічна закономірність спостерігалась і по вмісту клейковини. Між вмістом білка і клейковини в зерні встановлено дуже сильний кореляційний зв'язок $(\mathrm{r}=0,96)$. Слід також зазначити, що внесення калійних добрив підсилювало позитивний вплив азотних і фосфорних добрив на показники якості зерна пшениці озимої.

За узагальненим показником якості, розрахованим за системою величин Ацці, зерно пшениці озимої найкращої якості формувалося у варіантах досліду 3 внесенням $\mathrm{N}_{150} \mathrm{P}_{60} \mathrm{~K}_{40}$.

Отже, на чорноземі опідзоленому важкосуглинковому Правобережного Лісостепу України застосування калійних добрив дозою $\mathrm{K}_{40}$ на фоні $\mathrm{N}_{150} \mathrm{P}_{60}$ сприяло поліпшенню якості зерна пшениці озимої. При цьому підвищувалися маса 1000 зерен, вміст білка, клейковини та покращувалась натура зерна.

\section{Список літератури:}

1. Центило Л. В. Формування якості зерна пшениці озимої залежно від системи удобрення і обробітку грунту. Миронівський вісник. 2019. № 8. С. $152-$ 162. 
2. Карабач К. С. Урожайність та показники якості пшениці озимої залежно від систем основного обробітку грунту та удобрення. Науковий журнал «Рослинництво та трунтознавство». 2019. Т. 10. №3. С. 43-48. doi.org10.31548/agr2019.03.042

3. Сигида М. С., Айсанов Т. С, Есаулко А. Н. и др. Урожайность озимой пшеницы в зоне умеренного увлажнения в зависимости от систем удобрений и предшественников. Сб. научн. трудов Всероссийского научноисследовательского института овиеводства и козоводства. 2015. Т. 1. № 8. С. 985-987.

4. Господаренко Г. М., Черно О. Д., Нікітіна О. В. Агрохімія калію. Київ. ТОВ «ТРОПЕА». 2021.264 c.

5. Федюшкин А. В., Пасько С. В., Парамонов А. В., Медведева В. И. Влияние систематического внесения удобрений и предшественников на урожай и качество зерна озимой пшеницы. Известия Оренбургского государственного аграрного университета, 2017. №. 4 (66). С. 65-68. 


\title{
УПРАВЛЕНИЕ ТЕПЛОВЫМ РЕЖИМОМ ЗДАНИЙ КАК ОДИН ИЗ СПОСОБОВ ЭНЕРГОСБЕРЕЖЕНИЯ
}

\author{
Поперешнюк Наталья Александровна \\ Ст.преподаватель \\ Бендерский политехнический филиал \\ ГОУ «ПГУ им. Т.Г. Шевченко»
}

Современные требования к проектированию систем отопления диктуют в качестве обязательного условия автоматическое управление ими [1]. Очевидно, что такое управление должно повысить эффективность функционирования систем отопления, а соответственно обеспечить оптимальные параметры внутреннего воздуха при минимальных затратах топливно-энергетических ресурсов.

Но в настоящее время большая часть многоквартирных домов в Приднестровье - это здания с устаревшими инженерными коммуникациями, а тепловые вводы в здания, как правило, подключены к тепловым сетям по не регулируемой зависимой схеме. При таких схемах подключения теплоноситель из тепловой сети поступает непосредственно в систему отопления, что исключает возможность местного управления тепловым режимом здания и, как правило, вызывает «перетопы» в зданиях в начале и конце отопительного периода, когда температура наружного воздуха колеблется в пределах нуля градусов. А невозможность снижения температуры теплоносителя в тепловых сетях до значений, требуемых для нужд отопления при высоких температурах наружного воздуха, объясняется тем, что регулирование тепловых сетей производится по совмещенной нагрузке отопления и ГВС.

Для решения данной проблемы предложены следующие решения:

- замена не регулируемых тепловых вводов на автоматизированные регулируемые по погодозависимому графику;

- устройство автоматизированных индивидуальных тепловых пунктов при независимом присоединении к тепловым сетям.

И те, и другие хорошо зарекомендовавшие себя в последние годы. Данные решения позволяют регулировать температуру теплоносителя, поступающего непосредственно в отопительные приборы системы отопления здания, в соответствии с температурой наружного воздуха, что может обеспечить экономию тепловой энергии в пределах 10-40\% в зависимости от конкретных условий эксплуатации. А при независимой схеме присоединения, к тому же, гидравлически изолировать систему отопления здания от тепловых сетей через пластинчатый теплообменник.

Для достижения максимального эффекта необходимо учитывать реальные теплотехнические характеристики конкретного здания и его системы отопления. 
Для обеспечения погодозависимого управления тепловым режимом здания, в зависимости от схемы присоединения системы отопления к тепловым сетям, необходима установка регулирующего клапана (двух- или трехходового), циркуляционного насоса и контроллера (рис.1 и 2), который анализирует температуры наружного и внутреннего воздуха, а также температуру теплоносителя в подающем и обратном теплопроводе системы отопления [2]. Принцип такого управления заключается в поддержании постоянной температуры внутренних помещений с учетом изменения наружной температуры воздуха.

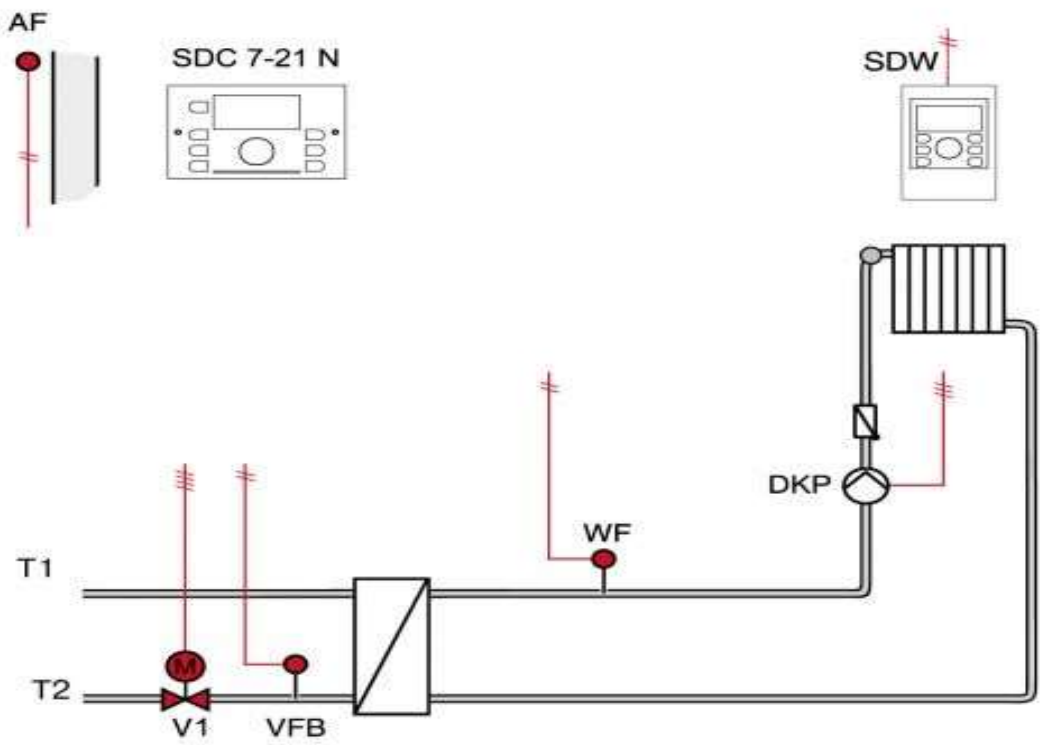

Рисунок 1. схема независимого присоединения системы отопления: SDC7-21N - котроллер; AF - датчик температуры наружного воздуха; VFB, WF - датчики температуры теплоносителя; V1 - двухходовой регулирующий клапан; DKP - циркуляционный насос системы отопления; SDW - датчик температуры внутреннего воздуха или комнатный модуль для удаленного регулирования.

Алгоритм поддержания постоянной внутренней температуры помещений в зависимости от температуры наружного воздуха встроен в автоматику контроллера. Зависимость между этими значениями, а также значениями температуры теплоносителя в теплопроводе системы отопления называется кривой нагрева. Как уже отмечалось выше, для обеспечения максимального эффекта, значения кривой нагрева необходимо выстроить в зависимости от теплотехнических и конструктивных особенностей конкретного здания, типа системы отопления в нем и других факторов, оказывающих влияние на поддержание оптимальной внутренней температуры отапливаемых помещений. 


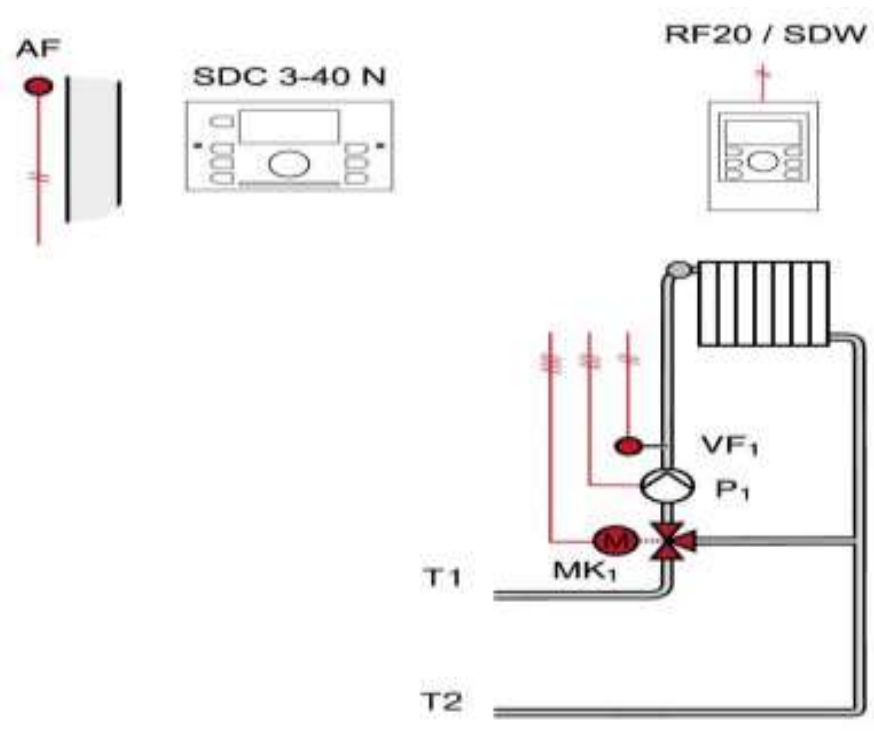

Рисунок 2. схема зависимого присоединения системы отопления к тепловой сети: SDC3-40N - котроллер; AF - датчик температуры наружного воздуха; VF1- датчик температуры теплоносителя; MK1 - трехходовой регулирующий клапан; P1 - циркуляционный насос системы отопления; RF20/SDW - датчик температуры внутреннего воздуха или комнатный модуль для удаленного регулирования.

Наклон кривой нагрева можно рассчитать по следующей формуле:

$\mathrm{a}=\frac{\left(t_{\text {воды } \max }-t_{\text {воды } \min )}\right)}{t_{\text {нар. } \max -}-t_{\text {нар. } \min }}$

где

$t_{\text {воды max }}$ - максимальная температура теплоносителя в подающем теплопроводе системы отопления, при самой низкой наружной температуре,${ }^{\circ} \mathrm{C}$;

$t_{\text {воды min }}-$ минимальная температура теплоносителя в подающем теплопроводе системы отопления, когда потребность в отоплении отпадает, ${ }^{\circ} \mathrm{C}$;

$t_{\text {нар.max }}-$ максимальная наружная температура, при которой отопление еще функционирует, ${ }^{\circ} \mathrm{C}$;

$t_{\text {нар.min }}-$ минимальная наружная температура в данной местности ${ }^{\circ} \mathrm{C}$.

В зависимости от типа системы отопления и температуры теплоносителя в подающем теплопроводе, наклон кривой нагрева может находиться в пределах от 0,2 до 1,4 для низкотемпературных систем отопления, и от 1,4 до 2,0 для традиционных радиаторных систем отопления многоквартирных домов [3]. Чем точнее будет задана кривая нагрева для конкретных условий эксплуатации, тем выше будет эффективность работы системы отопления и экономия энергии.

Понятно, что в многоквартирных домах технически очень сложно, да и не целесообразно, устанавливать датчики температуры внутреннего воздуха в каждом отапливаемом помещении. Для этого необходимо выбрать одно помещение, в котором будет очень точно поддерживаться внутренняя температура, а ее приемлемость для остальных помещений будет зависеть от правильности выбора помещения.

Вывод: 
Существует возможность управления тепловым режимом здания, не только во вновь строящихся системах отопления, но и в уже действующих. Достаточно модернизировать или дооснастить не достающим оборудованием тепловые вводы и правильно настроить автоматику в зависимости от теплотехнических и конструктивных особенностей конкретного здания и типа системы отопления в нем.

\section{Список литературы:}

1. СНиП ПМР 41-01-2011. Отопление, вентиляция и кондиционирование

2. С. Дейнеко. Погодозависимое регулирование для тепловых пунктов [Электронный pecypc] URL: https://aw-therm.com.ua/pogodozavisimoeregulirovanie-dlya-teplovyh-punktov/ (Дата обращения: 15.02.2021)

3. Регулирование температуры в помещениях с теплыми полами и радиаторами [Электронный ресурc] URL: http://homeengineering.net/articles/regulation/regulation.shtml (Дата обращения: 15.02.2021) 


\title{
МОДЕРНІЗМ У ЛІТЕРАТУРНО-МИСТЕЦЬКИХ КОНЦЕПЦІЯХ: ЗАГАЛЬНОЄВРОПЕЙСЬКИЙ ТА УКРАЇНСЬКИЙ ДОСВІД
}

\author{
Бабунич Юлія Ігорівна, \\ Ph.D., старший викладач \\ Львівська національна академія мистецтв
}

Утвердження нових принципів у мистецтві модернізму мало своєрідний маніфестаційний характер. Безперечно, мистецькі течії першої третини XX ст. мали концептуальне підгрунтя, часто оформлюючись спочатку теоретично. Якщо раніше художні стилі чи напрямки виникали без певних програм, природно доповнюючи людське буття, то тепер - в часі модернізму - відчувалась потреба у директивах і роз'ясненнях. Не випадково мистецтво першої третини XX ст. сповнене маніфестами, програмами, інструкціями, вказівками, проектами, які часом виникали раніше, ніж якийсь „ізм”. До прикладу, ще ніхто не знав про футуризм, коли Ф.-Т. Марінетті опублікував у паризькій газеті „Фігаро” 1909 р. свій маніфест [1-47].

Кожний новий мистецький напрямок чи течія, що з'являлися у період модернізму, були пов'язані з текстами. Без подібного теоретичного підгрунтя саме мистецтво могло залишитися незрозумілим чи, навпаки, занадто однозначним. Художники-авангардисти також це усвідомили, тому й почали писати книги і статті, щоденники і листи. I якщо вони самі написали мало, то друзі-сучасники, родичі намагалися залишити про них спогади, які теж сприймаються як документ. Вагома роль належить у цьому випадку i художній критиці.

У Європі теоретична база мистецьких рухів першої половини XX ст. формувалася у залежності від їх розвитку. У 1911-1913 рр. кубісти на чолі $з$ П. Пікассо і Ж. Браком підсумовують свої пошуки, проголосивши основні принципи кубізму, вважаючи адекватним відображення дійсності за допомогою геометричних композицій. На становлення цієї ідеї значний вплив справили наукові відкриття кінця XIX - початку XX ст. Принципи кубізму заперечували можливість пізнання мистецтвом навколишньої дійсності, можливість відтворення реальної краси. Ініційовані фовізмом і кубізмом творчі експерименти французькі теоретики намагаються пов'язати 3 національною традицією. Відомий теоретик кубізму А. Глез підкреслює, що „Франція розглядає твори найбільш свавільних митців сьогодення як породження нашої національної традиції” [2-165].

Паралельно в Італії розробляється концепція футуризму, чиє становлення пов'язують передусім з ім'ям Ф. Марінетті. 3 часу появи першого маніфесту футуристів точиться боротьба за „пріоритет у перебудові естетичного 
середовища". На початку XX ст. з'являються теоретичні роботи, які мають на меті обгрунтувати принципи футуризму: „Футуризм” Т. Марінетті, „Футуристська антитрадиція: маніфест-синтез” Г. Аполлінера, „Футуристичний маніфест Монмартру” Ф. Дель Марля та ін.

Теоретична програма футуристів абсолютизувала значення форми мистецького твору. Заперечуючи культуру минулого, футуристи схилялись перед технікою, індустрією, швидкістю, привнесеними технічним розвитком новими ритмами. Захоплюючись рівнем технічного розвитку $\mathrm{XX}$ ст., вони водночас доводили, що технічний прогрес веде до духовного зубожіння, що техніка з часом знищить свого творця - людину. Слід зазначити, що футуристи, можливо на інтуїтивному, емоційному рівні, але відчули суперечність між технічним прогресом як процесом творення нового та його наслідками, які можуть виявитися руйнівними для людини й людства в цілому. Часом філософія творчості італійських футуристів доводила їх до естетизації потворного. Проте футуризм не можна вважати явищем суто італійським. Його вплив позначився, зокрема, на творчості митців Росії й України. Тут футуризм проявився у більш „м'якому” вигляді.

У теоретичних положеннях абстракціонізму відчутний вплив філософсько-естетичної теорії інтуїтивізму. Досить згадати тези

A. Бергсона про художню творчість як самовиявлення митця, про художника як творця нової, вивільненої від дійсного життя реальності - мистецтва. Серед спроб теоретичного обгрунтування абстракціонізму особливу увагу дослідників привертала позиція П. Мондріана, який був і теоретиком, i практиком абстрактного мистецтва. Він вважав, що абстракціонізм має замінити „природу” „суб'єктом” і якомога послідовніше схематизувати зображення. Мондріан полемізував з кубістами і стверджував, що абстракція будується на руйнуванні простору й об'єму, на зміну яким приходять лінія і колір.

Послідовне обгрунтування абстракціонізму міститься в теоретичних розробках В. Кандінського. Він наголошував на необхідності свідомого відриву від дійсності, на його протиставленні інтелектові та почуттям. У теоретичній праці Кандінського „Про духовне в мистецтві” завдання творчості визначаються як вплив „Психічною силою” кольору на свідомість [3-70-73]. Світ внутрішніх суб'єктивних переживань митець втілює в „духовну сутність” трикутників, квадратів, циліндрів, у складну символіку кольорів.

Теоретична програма сюрреалізму формувалася за безпосередньої участі 3. Фройда, яскраво проілюструвавши своїми мистецькими творами його теорію психоаналізу. Сюрреалісти (на чолі з А. Бретоном) цілком підтримали думку Фройда про невичерпність позасвідомого, його активний вплив на життя кожної людини. Теоретичний вплив психоаналізу на розуміння сюрреалістами творчого процесу згодом втілився у численних мистецьких програмах i деклараціях. У 1924 р. з'являється перший „Маніфест сюрреалізму", написаний Бретоном. Теоретичне обгрунтування цього напряму базується передусім на розгляді співвідношення „логіка- 
алогічність", на визначенні міри випадковості у виборі теми твору, на теорії сновидінь, тлумаченні снів та їхньому художньому втіленні у конкретних творах, на абсолютизації „вільних асоціацій” та символів [2-182].

У порівнянні із Західною Європою, наукове підгрунтя модернізму в Україні спочатку оформилось у ділянці літератури. Це пояснюється специфікою розвитку нової культурної доби на наших теренах - спочатку модернізм в Україні завоював літературу, i лише згодом розвинувся у мистецтві [4-181].

В Україні теоретичне підгрунтя мистецьких течій першої третини ХХ ст. не було чітко розмежоване за напрямками. У цей час існує загальна тенденція до теоретизації модернізму з одного боку, і роздуми над різними аспектами художньої творчості - з іншого. Українські модерністи не маніфестували свої наміри прямо. Як вже зазначалося, український модернізм починався 3 літератури, тому й критика пов'язана насамперед 3 його розвитком у письменній культурі.

Показовим для зародження модернізму в Україні було видання альманаху М. Вороного „З-над хмар і долин” (Одеса, 1903), з яким часто пов'язують початок українського модернізму. Заклик Вороного укласти „Український альманах” пролунав 1901 р. в „Літературно-науковому віснику”. С. Сфремов у статті „В поисках новой красоты” назвав цей заклик маніфестом українського модернізму [5-97]. Саме М. Вороний зробив спробу структурувати новий період у мистецтві і культурі України. У дещо нечіткій формі пролунав заклик орієнтуватися на європейськість, молоде покоління, сучасність i свободу творчості. Йшлося про заперечення принципів народництва і реалізму.

Модернізм періоду „Молодої Музи” (1910-ті рр.) не мав концептуальної естетичної програми, хоча й представлений кількома відомими заявами. Стаття О. Луцького у газеті „Діло” за 17 листопада 1907 р., яку Франко назвав „Маніфестом „Молодої Музи”, відбиває основні новації в українській культурі початку ХХ ст.

Подальший розвиток цих ідей у критиці належать М. Свшану та його колегам із київського журналу „Українська хата” (1909-1914). Їхній дискурс засвідчував намір розширити рамки української культури, модернізувати і1і. Журнал друкував деякі переклади сучасної художньої літератури й наукових праць, що підсумовували тенденцію переорієнтації українського інтелектуального життя. Критика на сторінках „Української хати” базувалася в основному на засадах естетики. Як зазначав М. Сріблянський, головне - не про що писати, а як писати. Головне - творчість, в якій на перше місце висуваються індивідуальність митця та його психологія. Може, саме тому на сторінках журналу часто з'являються екскурси у філософську творчість Ніцше. У статті „Проблеми творчості” М. Свшан говорить, що проблеми творчості - це проблеми індивідуалізму. Це й відрізняло модернізм „Української хати” від попереднього періоду М. Вороного.

Ідеї Свшана вирізняли широке філософське розуміння сучасності, переоцінка канонів, індивідуалізм, психологізм. На його думку, завдання 
„штуки” - це виховання індивідуальності, людської одиниці, яка пізніше могла б змінити життя суспільства. Тільки отримавши таких художників, саме мистецтво почне промовляти вже не до одиниць, а до загалу. Самотність сучасного митця - зворотний бік його індивідуалізму- бачиться неодмінним атрибутом мистецтва. Конфлікт із широким загалом стає драмою митця, але водночас, і необхідним компонентом творчості.

Журнал „Шлях” на початках задекларував себе продовжувачем традицій „Української хати”. В його основі знову ж таки лежать ідеї свободи мистецтва та індивідуальності. У статті „Від редакції. Слово про незалежність думки" (1918р.) обстоюється незалежність у всіх іiі формах і проявах, зокрема у творенні новітнього мистецтва. Свої мистецькі візії автори висловлюють у статтях на теми живопису і театру. Мова йде про необхідність зламу старих канонів, про необхідність динамічності у мистецтві. У статті про „статичне” (імпресіонізм і кубізм) і динамічне мистецтво (футуризм) О. Огієнко пише: „Сучасність з іiі надзвичайно пошвидшеним ритмом, у вищій мірі динамічна; вона не може задовольнитися статичним малярством" [5-178].

„Шлях” в цілому окреслив певні рамки модернізації культури. Бути модерним (у значенні „сучасний”) на думку авторів означало бути аполітичним і незалежним у мистецтві.

У цей же час з'являються перші паростки українського футуризму. 1914 р. вийшла друком книжка М. Семенка „Дерзання”. До модерністів він себе не зараховував, хоча на початках своєї футуристичної творчості задекларував, що „шукає квінтесенцію модерного життя”. Футуризм Семенка був концептуальним явищем. В ньому поєднувалися митець і теоретик. Короткий авторський вступ до книжки „Дерзання” під заголовком „Сам” вважається першим „маніфестом” футуризму в Україні [6-83]. Суть виступу зводилася до формули : де є культ, там немає мистецтва; мистецтво має бути сучасним. Слова Семенка „я палю свій „Кобзар” стали яскравими визначниками українського футуризму у критиці. Один із найбільш показових критичних виступів стосовно цього питання належить М. Сріблянському - у 1914p. в Українській хаті” він надрукував свій „Етюд про футуризм”. На той час про футуризм мало писали, тому Семенкові слова були чи не єдиними фактами, що давали відомості про цей рух.

Ще два теоретичні тексти Семенка вийшли того ж 1914 року - це „Кверофутуризм” (передмова до однойменної збірки віршів) і „Pro Domo Sua”. Серед ідей висувалася теза, що мистецтво $\epsilon$ рухом, процесом, плинністю. Серед наступних теоретичних напрацювань автора - статті „Мистецтво переходової доби” (1919р.), „Постановка питання в теорії мистецтва переходової доби (Панфутуристичний маніфест)” (1922 р.), „Деякі наслідки деструкції” (1922 р.), „Організаційний принцип і мистецтво слова” (1922 р.), „Поезомалярство” (1922р.) та ін. Головною ознакою мистецтва футуризму визнавалася деструкція.

Якщо маніфести європейського варіанту течії подекуди закликали до радикальних змін у мистецтві, проголошуючи, що „нема шедеврів без 
агресивності”, то в Україні теоретичне підгрунтя живописного футуризму скидалося радше на дослідження художніх форм і засобів. Навіть сам термін „футуризм” (як назва напряму) не завжди тлумачився однаково. Так, для французів футуризм - це, за висловом Г. Аполлінера, „свідчення світового впливу французького живопису від імпресіонізму до кубізму включно”. Для росіян та українців ( В. Каменський, В. Маяков та ін.) - це оновлення старослов'янської традиції, це „діалог” з мистецтвом Х ст. [2-167].

На особливу увагу заслуговує теоретична праця одного з фундаторів українського кубофутуризму у живописі О. Богомазова „Живопис та елементи" (1914р.). У ній він простежив генезу художньої форми, що народжується від руху первісного елемента - крапки - i далі, підкорюючись динаміці руху, складаються лінії, живописні площини, середовище й т. ін. Живопис, вважав Богомазов, - це самостійна система, яка живе своїм внутрішнім життям, постійно змінюється й оволодіває ритмом - категорією, яка, на думку художника, має кількісні та якісні ознаки.

Художник сприймав кубофутуризм як нове мистецтво, яке обстоює „самостійну вартість елемента живопису як носія відчуттів” митця. Це одна 3 важливих ознак пошуків футуристів, кубістів і кубофутуристів - носієм відчуттів митця повинен бути не зміст твору, а елементи форми. Наголошуючи на тому чи іншому елементі (кольорі, освітленні, деформації предмету, композиції), живописець аналізує власні почуття. Він стверджує: „Те, що сучасне мистецтво уявляється нам лише уламками від предметів натури, це лише прикра помилка... Лише тоді ми станемо митцями, коли звільнимося від страху перед новою формою, як а не містить у собі копії якогось предмета [7-254-256].

Теоретичну спадщину українського кубофутуризму доповнюють „Теоретичні нотатки” видатного скульптора і художника О. Архипенка. Тут він фіксує свої роздуми про метафізику, простір і час, митця, критику, філософію і мистецтво, засоби виразу у скульптурі та інші аспекти сучасного йому художнього життя. „Сучасне мистецтво у своїй основі більше пов'язане 3 індивідуальними релігійними поглядами, які виявляють собою моделі творчої свідомості, та з сучасною наукою і філософією. Воно повністю незалежне від доктрин або релігійних догм будь-якого типу" [8-58].

Роздуми над поняттям символіки у мистецтві зустрічаються вперше серед „модерністичних” теоретичних надбань. Архипенко називає символіку найскладнішою і найважливішою 3 усіх психофізіологічних дій та реакцій. Митець зараховує до символів „кожне вимовлене слово, кожний жест або міміку, кожну написану літеру або цифру". Музика, мистецтво і релігія грунтуються на символіці. Вона, водночас, є, на думку Архипенка, найтоншим i найнебезпечнішим засобом мистецтва. „3 одного боку, за допомогою символіки можна досягти вершини геніальності; 3 другого, цілком можливо впасти до пересіченості. Витончене застосування символів може наближатися до багато значущої абстракції, але якщо самі символи абстрактні, починається пересіченість” [8-59]. 
Окремим розділом теоретичних напрацювань періоду модернізму $\epsilon$ публікації, пов'язані з першими виставками нового мистецтва. Іздебський, який виступав організатором виставок, що відбувалися впродовж 1909-1910-х рр. в Одесі, Києві, Петербурзі і Ризі під назвою „Салон” не обмежився лише традиційним показом художніх творів. Іздебський прочитав також лекції : „Про завдання сучасного живопису” і „Сучасне мистецтво і Місто”. У першій, що вийшла статтею під назвою „Новий живопис”, він зробив спробу подати історію сучасного мистецтва. Для сприйняття творів нового мистецтва, пише В. Іздебський, необхідно, насамперед, усвідомити і „... сприйняти кілька основних принципів, потрібно підійти до витонченого і складного у своїй простоті мистецтва, засвоївши певний комплекс художніх, чи, вірніше, живописних ідей, бо еволюція, чи, якщо хочете, революція відбулася, насамперед, в області самої ідеї живопису" [9-21].

Модернізм відзначається багатогранністю творчих особистостей. Митці водночас виступали теоретиками нового мистецтва, викладаючи свої думки, точки зору, переконання у критичних статтях, наукових розвідках, книжках. Взаємозв'язок слова і дії надавав їхньому мистецтву синтетичного характеру довершеності.

\section{Список літератури}

1. Художественная культура XX века. Развитие пластических искусств. Москва, 2002. 366 с.

2. Левчук Л. Західноєвропейська естетика XX ст. Київ : Либідь, 1997. 251 c.

3. Кандинский В. В. О духовном в искусстве. Москва : РИПОЛ Классик, 2016. $254 \mathrm{c}$.

4. Поліщук Я. Міфологічний горизонт українського модернізму. ІваноФранківськ : Лілея-НВ, 2002. 391 с.

5. Павличко С. Дискурс модернізму в українській літературі. Київ: Либідь, 1997. 357 c.

6. Ільницький О. Шевченко і футуристи. Сучасність. Мюнхен, 1989. Ч. 5 (337). С. 83-93.

7. Шудря М. Бунтівний „кубофутурист” (до 120-річчя від дні народження О. К. Богомазова). Українська академія мистецтва. - Київ, 2000. С. 254 263

8. Архипенко О. "Всі ідеї є у всесвіті”. Із теоретичних нотаток. Музейний провулок. Київ, 2004. № 1. С. 58-61.

9. Кашуба Е. Первые авангардные выставки в Киеве 1908-1910 гг. Київ : Тріумф, 1998. $54 \mathrm{c}$. 


\title{
РЕАЛІЗАЦІЯ ВАЛЕОЛОГІЧНОГО ВИХОВАННЯ У ПРОЦЕСІ ВИВЧЕННЯ БІОЛОГІЇ
}

\author{
Упатова Ірина Петрівна \\ Доктор педагогічних наук, доцент \\ Комунальний заклад \\ «Харківська гуманітарно-педагогічна академія» \\ Харківської обласної ради

\section{Стрюкова Світлана Євгенівна} \\ Студент \\ Комунальний заклад \\ «Харківська гуманітарно-педагогічна академія» \\ Харківської обласної ради
}

У нашому сторіччі, є багато негативних факторів, які впливають на організм людини. Проблема валеологічного виховання полягає в тому, що останнім часом відсоток захворювань підростаючого покоління в рази вище ніж у інших вікових груп населення.

Основами валеологічного виховання займалися вчені, які досліджували різні його аспекти. Так, Л. Сущенко, І. Сущева та інші вважали, що найголовнішим акцентом валеологічного виховання $\epsilon$ те, що людина повинна до здоров'я відноситися з відповідальністю. М. Амосова, Н. Артамонова та інші розглядали питання, щодо формування здорового способу життя. Н. Колотий, Н. П'ясецька доводили, що валеологічне виховання спрямоване на самовияв людини та інші соціальні аспекти життя [1].

Глобальні проблеми здоров'я людства сприяли виникненню самостійної галузі знань - «валеології», під якою розуміється наука про формування, збереження, зміцнення і відновлення здоров'я людини [2].

Великі можливості щодо формуванні здорового способу життя дітей, мають заклади загальної середньої освіти. Саме в шкільному віці закладаються основи здоров'я людини та здорового способу життя, формується ціннісне ставлення не тільки до свого здоров'я але й до здоров'я інших.

Тому, саме в закладі загальної середньої освіти потрібно створювати таке освітнє середовище, яке сприятиме зміцненню здоров'я, прищепленню любові до природи, оскільки людина - частина природи, а ії життя залежить від стану довкілля. Таке освітнє середовище має стати основою валеологічного виховання, як цілеспрямованого процесу формування здорового способу життя.

Першочерговими завданнями валеологічного виховання здобувачів загальної середньої освіти є формування в них поняття «здоровий спосіб життя»; ціннісного ставлення не тільки до свого здоров'я, але й до здоров'я інших людей; 
прагнення щодо здорового способу життя; розвиток умінь і навичок, що лежать в основі здорового способу життя.

Серед шкільних предметів особливе місце в валеологічному вихованні займає біологія. Вивчення біології дозволяє не тільки знайомити школярів із компонентами здорового способу життя, а й пояснити ці компоненти 3 біологічної, психологічної та соціальної точок зору, сприяти формуванню ціннісного ставлення до здоров'я, розвивати прагнення зберегти здоров'я.

Слід зазначити, що валеологічне виховання буде більш ефективним, якщо:

1) чітко визначені мета і завдання валеологічного виховання, які спрямовані на формування в учнів поняття «здоровий спосіб життя»;

2) визначено основний і додатковий навчальний зміст курсу біології, що сприяє реалізації завдань валеологічного виховання. Наприклад, якщо проаналізувати навчальну програму з біології за 8 клас, то можна зазначити, що під час вивчання кожної теми прослідковується валеологічний аспект. Наприклад, при вивченні теми: «Опора та рух», учні повинні усвідомити, що для збереження фізичного здоров'я людина повинна рухатися. Крім того робиться акцент на безпечне поводження зі спортивним (і не тільки) приладдям. Під час вивчення теми «Обмін речовин та перетворення енергії в організмі людини» учні орієнтуються на усвідомлення значення збалансованого харчування для збереження здоров’я людини. Під час вивчення теми «Травлення» учні повинні усвідомити важливість гігієни харчування, важливість профілактики захворювань зубів i органів травлення, зрозуміти, що алкоголь і тютюн негативно впливають на здоров'я не тільки травлення , але й дихання (наступна тема). Під час вивчання теми «Транспорт речовин», учні усвідомлюють важливість дотримання правил переливання крові, для запобігання захворювань, що передаються через кров; розуміють важливість заходів, спрямованих на запобігання захворювань серцево-судинної системи. При вивченні теми «Виділення. Терморегуляція» учні усвідомлюють який вплив має алкоголь на органи системи виділення, розуміють правила техніки безпеки, безпечної поведінки в побуті тощо.

Аналіз навчальної програми з Біологї та екології (10-11 клас), засвідчив, що під час вивчання теми «Спадковість і мінливість» (10 клас) учні вивчають спадкові хвороби, а також причини захворювань людей зі спадковою схильністю; при вивченні теми «Репродукція та розвиток» (11 клас), розглядається вплив різноманітних чинників на ріст i розвиток людини, профілактика онкологічних захворювань, вплив способу життя на формування людського організму. В темі «Біологічні основи здорового способу життя» учні вивчають і усвідомлюють принципи і складові здорового способу життя, безпеку і статеву культуру, негативні впливи на здоров’я людини, а також профілактику різних захворювань.

3) впроваджується в урок спеціальні методи i методичні прийоми, що забезпечують ефективну реалізацію процесу валеологічного виховання. Наприклад, інтерактивна вправа «Модель здоров’я» (учням пропонується зобразити модель здоров’я, в яку можуть входити всі його складові (фізична, психічна, соціальна, духовна, особистісна складова здоров’я); складання 
пам'ятки «Допоможи собі сам»; валеологічні дебати «Ранні статеві зв'язки: за чи проти?» (обговорення аргументів щодо проблеми наслідків ранніх сексуальних стосунків) тощо.

4) використовуються, такі форми і види робіт як: підготовка повідомлень і доповідей, інформаційних розповідей про здоровий спосіб життя; бесіди про цінності здоров'я; дискусії про шкоду алкоголю, наркотиків, паління на організм людини; діалоги про здоров'я людей нашої планети; навчальні ігри (організаційно-діяльні, рольові, пізнавально-дидактичні), що сприяють усвідомленню цінностей щодо здорового способу життя.

5) проводиться моніторинг результатів формування здорового способу життя школярів, який дає можливість корегувати процес валеологічного виховання. Моніторинг може бути в вигляді опитування, коли під час уроку вчитель в бесіді знаходить прогалину в знаннях учнів, або ж у вигляді анонімного тестування ( в старшому шкільному віці).

Таким чином, виходячи 3 вищезазначеного, можна зробити наступні висновки, для реалізації завдань валеологічного виховання в основній школі під час реалізації освітнього процесу із біології необхідно впроваджувати валеологічний зміст, форми, методи і засоби навчання, створювати виховні валеологічні ситуації, що примушують замислитися про цінність здоров'я, сприяють самопізнанню власного здоров'я; формуванню адекватної самооцінки, яка веде до зміцнення здоров'я.

\section{Список використаних джерел}

1. Філіпп'єва О. А. Валеологічне виховання молодших школярів: сутність проблеми. Науковий вісник МДУ імені В. О. Сухомлинського. № 1.30. С. 160-162.

2. Лукащук-Федик С. В. Бадюк Р. А. Циквас Р. В. Валеологія. Навчальний посібник. 2006. С. 6-10.

3. Гриньова М. В. Методика викладання валеології : навчально-методичний посібник. Полтавський державний педагогічний університет імені В. Г. Короленка. 2-е вид. Полтава : АCMI, 2003. 220 с.

4. Ващенко Л. Шкільна валеологічна освіта причини та шляхи їі розв'язання. Біологія і Хімія в школі. 2000. №1. С. 23-30.

5. Поташнюк I. В. Професійна валеологічна підготовка майбутніх біологів у вищих закладах освіти III- IV рівнів акредитації: автореф. дис... канд. пед. наук: 13.00.04 / Ін-т педагогіки і психології проф. освіти АПН України. Київ, 2000. 22 c. 


\title{
BENCHMARKING AS A DIRECTION OF INCREASING THE COMPETITIVENESS OF THE ENTERPRISE
}

\author{
Tulchinskiy Rostislav
}

Doctor of economics science, Professor Head of the management and public administration department IHE "Academician Yuri Bugay International Scientific and Technical University"

\section{Ruzhytskyi Andrew}

Associate professor of the management and public administration department IHE "Academician Yuri Bugay International Scientific and Technical University"

In foreign practice, one of the dominant and most promising areas is to increase the competitiveness of enterprises is strategic benchmarking. Recently, benchmarking has become one of the most effective and recognized methods of business improvement and is one of the most popular management tools. Benchmarking is a characteristic strategic activity of companies in Japan, USA, UK, Germany and China in the context of globalization and is seen as a systematic process that has a complex structural organization and determines the company's behavior in the market, the segmentation and positioning of the company, its products and services. target segments [1].

The concept of benchmarking occupies a key place in the system of strategic planning of such foreign companies as "Toyota", "Nissan", "Ford", "Xerox", "Volkswagen", "IBM" and is a very effective tool that allows them to identify major trends market, to predict future directions of its development, to increase the competitiveness and to carry out the analysis of the competitive environment, to determine formation of the information environment, to allocate vertical and horizontal information streams.

Benchmarking - "is the process of comparing its activities with the best companies in the market and in the industry with the subsequent implementation of changes to achieve and maintain competitiveness" [2].

Benchmarking is a constant business process, during which the evaluation of competitors 'strategies, comparative analysis of the results of their best practices, the formation of their own strategy in the context of globalization, determines the place of benchmarking strategy in the system of foreign companies' relations with competitors. marketing wars, interaction marketing, strategic marketing orientation, competitive intelligence, industrial espionage.

The basic idea is that the company uses existing solutions to solve problems. The priority is to find similarities between your business and the more successful. 
Benchmarking is not a panacea for all organizational problems, but with its help you can find new ideas to solve existing problems and achieve goals. The purpose of benchmarking is to improve the system and increase the competitive advantage of the firm in the long run. This goal is achieved through the solution of specific issues.

For benchmarking, the tasks are determined by the essence of the process of benchmarking: measuring the performance of your own company and comparing them with the selected benchmark, as well as analysis of best practices of others and its implementation in your firm. That is, it is necessary to find a special, unique feature of the product (service), which in the future can be positively assessed by customers.

In Ukrainian companies, the benchmarking strategy is used in companies of both large and medium and small businesses. In most cases, companies use this method to analyze the competitive environment and to a lesser extent for actions related to strengthening the company's competitiveness in the industry and making qualitative changes in the structure of their business [4].

However, it is important to note that in foreign companies the use of benchmarking is regulated by special government agencies, within which special units are created that are responsible for the quality selection of benchmarking partners.

Depending on the situation in the industry, each company chooses one or another strategy of competitiveness management.

Thus, the development of a strategy to manage the competitiveness of the enterprise allows the organization to determine the direction and method of its movement to the goals, and the implementation of the developed strategy to increase the competitiveness of the enterprise and its adjustment creates conditions for the organization to implement its development strategy.

Identification of key success factors is one of the main priorities in developing a strategy to improve the competitiveness of the enterprise. These facts can serve as the cornerstones of building a strategy to increase the competitiveness of each enterprise.

\section{References}

1. Dashko, I.M. (2020), "Research of basic methods for assessing the level of competitiveness of enterprises", Ekonomika ta derzhava, vol. 5, pp. 108-110.

2. Lozovsky, O., Dyachuk, M. (2018), "Strategic management as a factor in increasing the competitiveness of enterprises", Naukovyj visnyk Mykolaivs'koho natsional'noho universytetu imeni V. O. Sukhomlyns'koho. Ekonomichni nauky, vol. 2. pp. 31-35.

3. Tulchynska S.O., Kirichenko S.O., Savitsky N. Yu. Model TQM as a means of ensuring the level of competitiveness of products of domestic enterprises. Investment practice and experience. Vol. 8. 2018. P. 14-18.

4. Tulchinskaya S.O., Dergalyuk M.O., Radkevich D.O. Strategy to increase the competitiveness of Ukrainian producers in the world market in conditions of macroeconomic instability. Efficient economy. 2021. Issue 1. URL: http://www.economy.nayka.com.ua/?op=1\&z=8493 


\section{ГУДВІЛ В ОБЛІКУ ТА ЗВІТНОСТІ ПІДПРИЕМСТВА}

Беркун Поліна Сергіївна

Студентка курсу 4 групи 8 кафедра технології і організації ресторанного господарства Київський національний торговельно-економічний університет

\section{Шушакова Ірина Костянтинівна}

к.е.н, старший викладач

кафедра обліку та оподаткування

Київський національний торговельно-економічний університет

Гудвіл як ділова репутація, притаманна кожному бізнесу і $є$ його важливим елементом, адже прямо впливає на вибір клієнтів та інвесторів й, відповідно, прибуток компанії. Аналіз сучасних інформаційних джерел показує, що на сьогодні існує декілька підходів до тлумачення цього поняття.

Відповідно до пп. 14.1.40 ст. 14 Податкового кодексу України гудвіл, або вартість ділової репутації, - це нематеріальний актив, вартість якого визначається як різниця між ринковою ціною та балансовою вартістю активів підприємства як цілісного майнового комплексу, що виникає в результаті використання кращих управлінських якостей, домінуючої позиції на ринку товарів, послуг, нових технологій тощо. Вартість гудвілу не підлягає амортизації і не враховується під час визначення витрат платника податку, щодо активів якого виник такий гудвіл [1].

3 однієї сторони, гудвіл проявляє ознаки нематеріальних активів, а головною умовою визнання нематеріального активу $є$ його ідентифікація. У той же час гудвіл $є$ частиною репутації компанії, тому його не можна відокремити від неї. Такі розбіжності в поняттях й ускладнюють розуміння. Але спільною ознакою при визначенні гудвілу, як активу та репутації $є$ те, що він забезпечує прибуток у майбутньому, що перевищує ринкову вартість прибутку компаній 3 аналогічним предметом господарської діяльності.

Також варто зазначити, що гудвіл виникає лише в разі купівлі-продажу чи реорганізації підприємства та має чітку вартісну ознаку.

Згідно $з$ п. 4 Національного положення (стандарту) бухгалтерського обліку 19 «Об'єднання підприємств», гудвіл - це перевищення вартості придбання над часткою покупця в справедливій вартості придбаних ідентифікованих активів, зобов'язань і непередбачених зобов'язань на дату придбання [2].

Якщо охарактеризувати це поняття простіше з точки зору бухгалтерського обліку, то гудвіл є грошовою сумою, яку покупець компанії готовий заплатити понад балансову вартість іiі активів.

Відповідно до МСФЗ (IFRS) 3 «Об’єднання бізнесу» гудвіл - це майбутні економічні вигоди, які виникли в зв'язку з активами, які не можуть бути індивідуально ідентифіковані і окремо визнані [3].

Також варто звернути увагу на поняття «від’ємного гудвілу», або badwill, як запропоновано в статті Мадхурі Такур, креативної директорки Wallstreetmojo [4], 
оскільки гудвіл залежить як від позитивної, так і негативної репутації суб'єкта господарювання. Отже, можна дійти висновку, що між вартістю підприємства та чистою вартістю його активів завжди є різниця, яка і є гудвілом. Вона може бути додатною або від'ємною.

Для відображення гудвілу у бухгалтерському обліку, Інструкцією № 291 передбачено рахунок 19 «Гудвіл», який має такі субрахунки:

- 191 «Гудвіл при придбанні» - по дебету цього субрахунку відображається вартість гудвілу, який виникає при придбанні іншого підприємства, а по кредиту - втрати від зменшення корисності гудвілу і сума списаного гудвілу;

- 193 «Гудвіл при приватизації (корпоратизації)» - за дебетом цього субрахунку підприємства державного i комунального секторів економіки відображають вартість гудвілу, який виник при приватизації (корпоратизації), а по кредиту - суму списаного гудвілу [5].

При списанні суми втрат від знецінення групи активів, яка генерує грошові потоки, спочатку зменшується вартість гудвілу, до повного списання, а лише потім вартість інших активів групи. А при поновленні корисності групи активів, яка генерує грошові потоки, збільшується балансова вартість всіх активів групи, крім гудвілу. Тобто гудвіл не підлягає відновленню корисності, а тільки знецінюється [6].

При цьому в бухгалтерському обліку робляться такі записи (табл.1).

Відображення гудвілу у бухгалтерському обліку

\begin{tabular}{|c|c|c|c|c|}
\hline \multirow{2}{*}{$\begin{array}{l}\text { № } \\
\text { 3/II }\end{array}$} & \multirow{2}{*}{$\begin{array}{c}\text { Зміст } \\
\text { господарської } \\
\text { операції }\end{array}$} & \multicolumn{2}{|c|}{ Кореспонденція рахунків } & \multirow[b]{2}{*}{ Відображення суми } \\
\hline & & Дебет & Кредит & \\
\hline 1 & $\begin{array}{l}\text { Відображення } \\
\text { гудвілу при } \\
\text { придбанні в } \\
\text { обліку } \\
\text { підприємства- } \\
\text { покупця: }\end{array}$ & & & \multirow{3}{*}{$\begin{array}{c}\text { Перевищення } \\
\text { вартості придбання } \\
\text { над часткою покупця } \\
\text { у справедливій } \\
\text { вартості придбаних } \\
\text { ідентифікованих } \\
\text { активів, зобов'язань і } \\
\text { умовних зобов'язань } \\
\text { на дату придбання }\end{array}$} \\
\hline 1.1 & - при передплаті & $\begin{array}{c}191 \text { «Гудвіл при } \\
\text { придбанні» }\end{array}$ & $\begin{array}{c}37 \text { «Розрахунки } 3 \\
\text { різними } \\
\text { дебіторами» }\end{array}$ & \\
\hline 1.2 & $\begin{array}{c}\text { - при подальшій } \\
\text { оплаті }\end{array}$ & $\begin{array}{c}191 \text { «Гудвіл при } \\
\text { придбанні» }\end{array}$ & $\begin{array}{c}68 \text { «Розрахунки за } \\
\text { іншими } \\
\text { операціями» } \\
\end{array}$ & \\
\hline 2 & $\begin{array}{c}\text { Відображення } \\
\text { зменшення } \\
\text { корисності гудвілу }\end{array}$ & $\begin{array}{c}977 \text { «Інші витрати } \\
\text { звичайної діяльності» }\end{array}$ & $\begin{array}{c}191 \text { «Гудвіл при } \\
\text { придбанні» }\end{array}$ & $\begin{array}{c}\text { У межах балансової } \\
\text { (залишкової) } \\
\text { вартості }\end{array}$ \\
\hline 3 & $\begin{array}{c}\text { Відображення } \\
\text { списання гудвілу, } \\
\text { який виник у } \\
\text { процесі } \\
\text { приватизації } \\
\text { (корпоратизації) } \\
\text { підприємства }\end{array}$ & $\begin{array}{c}45 \text { «Вилучений } \\
\text { капітал» }\end{array}$ & $\begin{array}{c}193 \text { «Гудвіл при } \\
\text { приватизації } \\
\text { (корпоратизації)» }\end{array}$ & $\begin{array}{c}\text { У межах балансової } \\
\text { (залишкової) } \\
\text { вартості }\end{array}$ \\
\hline
\end{tabular}

Джерело: [6] 
Міністерством фінансів України надано роз'яснення щодо обліку та відображення у звітності підприємства інформації про гудвіл:

- П(С)БО 19 визначає порядок відображення в звіті порядок купівлі чи об'єднання підприємств, й, відповідно, гудвіл;

- форму фінансової звітності та їі склад визначають НП(С)БО1;

- підходи до розкриття інформації за статтями, зокрема за Балансом (Звітом про фінансовий стан) (форма № 1), внесеними до Методичних рекомендацій № 433;

- у разі вже наявності на підприємстві такого об'єкту обліку, як гудвіл, відповідна інформація відображається в Балансі (Звіт про фінансовий стан) у додатковій статті «Гудвіл» (рядок 1050);

- вартість гудвілу, що виникає при консолідації фінансової звітності материнського підприємства і фінансової звітності дочірніх підприємств, що відбивається в консолідованому балансі (Звіті про фінансовий стан) (форма № 1к) в рядку 1055 «Гудвіл при консолідації» [7].

Висновки. Гудвіл, 3 економічної та бухгалтерської сторони, - це самостійний, нематеріальний актив та джерело надприбутку, а також сума перевищення ринкової вартості компаній над балансовою вартістю ії активів. Сама ж сутність гудвілу охоплює широкий спектр ознак, що включають в себе репутацію, зв'язки, технології та інші елементи. Основним нормативним актом, який визначає методологічні засади обліку гудвілу, є НП(С)О 19 «Об'єднання підприємств». У НП(С)БО 19 «Об'єднання підприємств» зазначено певні особливості щодо обліку гудвілу, а саме: амортизація на гудвіл не нараховується, хоч він і відноситься до нематеріальних активів. А для грамотного відображення гудвілу на рахунках, варто звернутись до Інструкції №291.

\section{Список літератури}

1. Податковий кодекс України від 02.12.2010 p. № 2755 - IV. URL: http://zakon.rada.gov.ua/laws/show/2755-17

2. Національне положення (стандарт) бухгалтерського обліку 19 «Об'єднання підприємств», затверджене наказом Міністерства фінансів України від 07.07.1999 № 163. URL: https://zakon.rada.gov.ua/laws/show/z0499-99

3. Міжнародний Стандарт Фінансової Звітності 3 (МСФЗ 3) «Об'єднання бізнесу» від 01.01.2012. URL: https://zakon.rada.gov.ua/laws/show/929_006

4. Accounting Tutorials. Assets Tutorials. Badwill. By Madhuri Thakur. Reviewed By Dheeraj VaidyaDheeraj Vaidya, CFA, FRM. What is Badwill? URL: ttps://www.wallstreetmojo.com/badwill/

5. Інструкція про застосування Плану рахунків бухгалтерського обліку активів, капіталу, зобов'язань і господарських операцій підприємств і організацій, затверджена Наказом Міністерства фінансів України від 30.11.1999 № 291. URL: https://zakon.rada.gov.ua/laws/show/z0893-99
6. Лебединська
Я.
Гудвіл
про
основи.
URL: https://buhgalter911.com/uk/news/news-493599.html

7. Лист Міністерства Фінансів України від 12.03.2014 р. №31-08410-07- 
10/5182. URL: https://www.profiwins.com.ua/uk/letters-and-orders/treasury/52915182.html 


\title{
ОСОБЛИВОСТІ БАНКІВСЬКОГО КРЕДИТУВАННЯ ТРАНСПОРТНИХ ПІДПРИЕМСТВ НА СУЧАСНОМУ ЕТАПІ
}

\author{
Бойко Наталія Віталіївна \\ старший викладач кафедри фінансів, обліку і аудиту \\ Національний транспортний університет
}

Заяц Ольга Василівна старший викладач кафедри менеджменту Національний транспортний університет

Ефективне функціонування транспортного підприємства та високий рівень конкурентоспроможності можливе лише за умови використання підприємством різних фінансових ресурсів. Станом на початок 2020 р. власні фінансові ресурси транспортних підприємств становили 58,4\% [1] проти 67,6\% у 2015 p., 63,6\% у 2016 p., 61,2\% у 2017 p., 54,4\% у 2015 p. [2, с. 95]. Частка власного капіталу транспортних підприємств залишається високою з тенденцією до зменшення, що актуалізує застосування інші джерела фінансових ресурсів. Одним з таких слід вважати кредити комерційних банків, що можуть бути застосовані транспортними підприємствами для придбання основних засобів, в першу чергу, транспортних засобів, нематеріальних активів, довгострокових фінансових інвестицій, запасів, погашення поточної кредиторської заборгованості тощо.

Отже, кредитування транспортних підприємств в сучасних умовах потребує особливої уваги та науково обгрунтованого підходу, що зможе забезпечити формування фінансових ресурсів у достатньому для сталого розвитку та безперебійного функціонування підприємств.

Наукове підгрунтя фінансування транспортних підприємств, в тому числі кредитування знайшло місце у наукових доробках вітчизняних вчених: А. В. Базилюк, В. В. Бобиль, В. В. Бойко, С. В. Бойко, С. М. Голубка, В. В. Гошовська, Г. В. Кириченко, О. І. Никифорук, П. А. Овчар, О. М. Парубець, Д. О. Сугоняко, Л. Ю. Чмирьова, Н. О. Федяй [1-7] та інші. Всупереч доробку вітчизняних учених, питання щодо особливостей кредитування транспортних підприємств не має належного висвітлення за винятком кількох фахових публікацій [3-9]. В. В. Бобиль та С. В. Луцко обгрунтовують застосування комплексного підходу до активізації кредитування транспортних підприємств, «яку необхідно вирішувати не тільки комерційним банкам, але й Уряду, парламенту і Національному банку України» [3, с. 20]. В. В. Бойко та Г. В. Кириченко обгрунтовують посилення ролі держави у забезпеченні активізації кредитування транспортних підприємств, а саме «державного сприяння у їх фінансовому забезпеченні та створенні умов для залучення банківського капіталу в реальний сектор» $[4$, с. 256].

Метою $\epsilon$ дослідження сучасного стану кредитування транспортних підприємств 3 позиції ролі кредитування у формуванні фінансових ресурсів 
комерційних банків, а також 3 позиції схильності комерційних банків до кредитування транспортних підприємств.

У 2015-2020 pp. загальний обсяг кредитів, наданих депозитними корпораціями (крім Національного банку України) транспортним підприємствам коливався на рівні 29770-49324 млн грн з постійними помірними сезонними коливаннями. Поступово у 2019 р. відбулося зменшення кредитної активності транспортних підприємств та щомісячне зменшення залишків за кредитами, наданими транспортним підприємствам у березні-вересні 2019 р. становило 1418,8 млн грн.

У 2015-2020 pp. загальний обсяг кредитів, наданих депозитними корпораціями (крім Національного банку України) транспортним підприємствам коливався на рівні 29770-49324 млн грн 3 постійними помірними сезонними коливаннями. Поступово у 2019 р. відбулося зменшення кредитної активності транспортних підприємств та щомісячне зменшення залишків за кредитами, наданими транспортним підприємствам у березні-вересні 2019 р. становило 1418,8 млн грн.

У 2015-2020 pр. загальний обсяг кредитів, наданих депозитними корпораціями (крім Національного банку України) транспортним підприємствам коливався на рівні 29770-49324 млн грн з постійними помірними сезонними коливаннями. Поступово у 2019 р. відбулося зменшення кредитної активності транспортних підприємств та щомісячне зменшення залишків за кредитами, наданими транспортним підприємствам у березні-вересні 2019 р. становило 1418,8 млн грн.

Частка кредитів, отриманих транспортними підприємствами у загальному розмірі кредитного портфеля коливалася на рівні 4,0-5,0\% у 2015-2020 pp. 3 постійними помірними сезонними коливаннями. За динамікою частки кредитів, отриманих транспортними підприємствами можна визначити тенденцію до зменшення: у 2015 - першому півріччі 2016 рр., коли відносний показник зменшився з 4,8 \% до 4,2\%, що було гармонізоване зі зменшенням абсолютних розмірів кредитування; у першому півріччі 2017 р., коли відносний показник зменшився 3 4,7\% до 4,2\%, що було гармонізоване зі зменшенням абсолютних розмірів кредитування; у першому півріччі 2019 р., коли відносний показник зменшився з 4,8 \% до 4,2\%. У другому півріччі досліджуваних років відбувається підвищення кредитної активності транспортних підприємств та збільшення обсягів залучення кредитів комерційних банків до фінансування діяльності. Кредитна активність транспортних підприємств поступається кредитній активності суб'єктів господарювання торгівлі, переробної промисловості, сільського господарства, постачання електроенергії, газу.

Кредиторами транспортних підприємств $€$ комерційні банки України. Емпіричний аналіз кредитування транспортних підприємств обмежено 2019 р. відповідно до оприлюднених даних Національним банком України [10]. 3 урахуванням невисокої частки кредитів, отриманих транспортними підприємствами, частина комерційних банків не мала у власних кредитних портфелях кредитів транспортних підприємств (на початок 2019 р. - Альтбанк, Банк Фамільний, Ідея Банк, Правекс Банк, Аркада, Айбокс Банк, Кліринговий 
Дім, ІНГ Банк Україна, Банк Траст-Капітал, Кредит Європа Банк, Укрбудінвестбанк, Мотор-Банк, Банк 3/4, Портал та ін.) або їх частки становили менше одного відсотка.

Сучасний стан розвитку кредитування транспортних підприємств свідчить про пріоритетність кредитування наземного і трубопровідного транспорту (залишки коштів за наданими кредитами на початок 2019 р. - 25741,2 млн грн, на кінець 2019 р. - 12590,6 млн грн) та складського господарства та допоміжної діяльності у сфері транспорту (залишки коштів за наданими кредитами на початок 2019 р. - 16184,1 млн грн, на кінець 2019 р. - 18591,4 млн грн).

Водночас кредитування підприємств водного та авіаційного транспорту не має належного поширення у вітчизняній практиці, незважаючи на збільшення у 2019 р. на 27,9\% та 134,1\%, відповідно. Інша особливість кредитування підприємств водного та авіаційного транспорту - обмеженість складу кредиторів. За напрямом «Водний транспорт» кредити надавали лише Укрексімбанк, Банк Альянс, Райффайзен Банк Аваль, Приватбанк, Кредобанк, МТБ Банк, Полтава-банк, Укрсиббанк, Радабанк, ОТП Банк, Таскомбанк, за напрямом «Авіаційний транспорт» - Укрексімбанк, Банк Альянс, Райффайзен Банк Аваль, Приватбанк, Львів, Полтава-банк, Креді Агріколь Банк, Місто Банк, ОТП Банк.

Кредитні кошти - одне 3 джерел фінансування розвитку транспортних підприємств, що має значний потенціал як у частині придбання необоротних активів, у першу чергу транспортних засобів, так у частині фінансування поточних витрат та забезпечення безперебійності надання транспортних послуг. Банківський сектор України виступає кредитором транспортних підприємств 3 відносна стабільним рівнем кредитної активності останніх у довгостроковому періоді, проте протягом 2019 р. частка кредитів, наданих транспортним підприємством у кредитному портфелі комерційних банків зменшилася. Основними кредиторами транспортних підприємств є Сбербанк, ПриватБанк та Укрексімбанк $з$ одночасно високим рівнем непрацюючих кредитів. Розміри кредитних портфелів інших комерційних банків (Укргазбанк, Укрсиббанк, Райффайзен Банк Аваль, Ощадбанк, ПУМБ, ОТП Банк, Сітібанк тощо) менші 3 одночасно нижчим рівнем непрацюючих кредитів. Щоб активізувати процес залучення кредитних коштів до фінансування розвитку транспортних підприємств необхідно реалізовувати комплекс заходів 3 покращення кредитоспроможності підприємств, надання державної підтримки позичальникам та зменшення відсоткових ставок комерційними банками.

\section{Список літератури:}

1. Показники балансу великих та середніх підприємств за видами економічної діяльності станом на 1 січня 2020 року. URL: http://www.ukrstat.gov.ua/

2. Статистичний збірник «Діяльність суб'єктів господарювання 2018» URL: http://www.ukrstat.gov.ua/druk/publicat/kat_u/2019/zb/11/zb_dsg_2018.pdf 
3. Бобиль В.В., Луцко С.В. Кредитування підприємств транспорту в умовах кризи. Збірник наукових праць Дніпропетровського національного університету залізничного транспорту імені академіка В. Лазаряна. Проблеми економіки транспорту. 2011. Вип. 2. С. 19-20.

4. Бойко В.В., Кириченко Г.В. Роль кредитування у вирішенні проблем функціонування підприємств транспорту в сучасних економічних умовах. Вісник Наиіонального транспортного університету. 2010. № 21(1). С. 254-256

5. Бойко С.В., Гошовська В.В., Бойко Н.В. Волатильність бюджетного фінансування дорожнього господарства в Україні. Modern economics. 2019. № 14. C. 26-32.

6. Holubka S.M., Ovchar S.M. Financial aspects of national automobile transport development. Фінанс.-кредит. діяльність: проблеми теорії та практики. 2018. Вип. 1. С. 95-103.

7. Никифорук О.І., Чмирьова Л.Ю., Федая Н.О. Перспективи фінансування транспортних проектів у рамках міжнародної фінансової допомоги. Економіка України. 2015. № 4. С. 45-57.

8. Парубець О.М., Сугоняко Д.О. Обгрунтування джерел фінансування транспортного сектору України. Інвестииї̈: практика та досвід. 2017. №10. С. 56-60.

9. Фінансове та обліково-аналітичне забезпечення підприємств дорожньотранспортного комплексу : монографія / під наук. ред. проф. Базилюк А. В. Київ : Кондор, 2016. 237 с.

10. Наглядова статистика. URL: https://bank.gov.ua/ua/statistic/supervisionstatist/data-supervision\#1 


\section{ЕФЕКТИВНА СИСТЕМА МЕНЕДЖМЕНТУ ЯКОСТІ ЯК ВАЖЛИВА СКЛАДОВА УСПШШОГО ФУНКЦІОНУВАННЯ ПІДПРИЕМСТВА НА БУДІВЕЛЬНОМУ РИНКУ}

Бутенко Олена Петрівна, кандидат економічних наук, доцент, доцент кафедри менеджменту та публічного адміністрування Харківський національний університет будівництва та архітектури, Україна

\section{Чупир Олена Миколаївна,} доктор економічних наук, професор, професор кафедри менеджменту та публічного адміністрування Харківський національний університет будівництва та архітектури, Україна

\section{Садовниченко Олександр Вадимович,} старший викладач, кафедри менеджменту та публічного адміністрування Харківський національний університет будівництва та архітектури, Україна

Будівництво є однією з найважливіших галузей економіки будь-якої країни, яка вирішує безліч завдань, як державного характеру (обсяг ВВП), так і соціального, наприклад, будівництво і ремонт житла для громадян. Тому, важливість ефективного функціонування цієї галузі очевидна. Розвитку та підвищенню ефективності менеджменту будівельної галузі присвячені роботи таких вітчизняних фахівців як О. О. Кононової [1], Л. Л. Калініченко, Ю. Р. Сидорова [2], А. В. Колесник [3], Г. Й. Лучко, І. В. Когут [3] та інших. Зазначені автори досліджують перспективи розвитку будівництва, враховуючі існуючі ринкові умови, тому вважаємо актуальним дослідження переваг та можливостей, які отримують будівельні підприємства у разі використання системи менеджменту якості (СМЯ).

Будівельний ринок $\epsilon$ відкритою організаційно-господарською системою, що характеризується такими елементами:

1. Суб'єктами будівельного ринку. До яких належать: інвестори, замовники, підрядники, проєктно-вишукувальні організації, підприємства промисловості будівельних матеріалів, виробів і конструкцій, підприємства будівельного і дорожнього машинобудування, підприємства (заводи) - виробники технологічного, енергетичного та іншого устаткування, населення.

2. Об'єктами (предметами) ринкових відносин, які включають будівельну продукцію, (будівлі, споруди, об'єкти, їх комплекси тощо), будівельні машини, транспортні засоби, енергетичне, технологічне та інше обладнання, матеріали, вироби, конструкції, капітал, робочу силу, інформацію тощо.

3. Інфраструктурою ринку будівельного комплексу. 
4. Ринковим механізмом, який реалізується через співвідношення попиту i пропозиції, а також державного регулювання діяльності суб'єктів будівельного ринку за допомогою податкових зобов'язань, антимонопольних заходів, амортизаційних відрахувань тощо.

5. Державним контролем, який передбачає регулювання та саморегулювання ринку, передбачає виділення інвестиційного (будівельного) бізнесу в спеціальну галузь господарського законодавства й адміністративного нагляду.

В умовах ринкових відносин будівельним організаціям доводиться зіштовхуватися з безліччю факторів, що негативно впливають на їх діяльність, а came:

1. конкурентні (ринкові) фактори - рівень конкуренції, попит i пропозиція, як на засоби праці, так і на предмети праці, тенденції та можливості розвитку ринку тощо;

2. політичні (державні) фактори - кредитно-грошова і податкова політика держави тощо;

3. економіко-господарські фактори - фактори, що безпосередньо впливають на основні економічні показники діяльності підприємства: прибуток, дохід, собівартість тощо.

Якщо негативний вплив політичних факторів досить важко нейтралізувати, то чинниками, які впливають на діяльність організації з боку ринку i внутрішніми економіко-господарськими факторами можна досить успішно керувати за допомогою ефективних механізмів стратегічного управління організацією. Одним з таких успішних механізмів є система менеджменту якості (СМЯ) підприємства, яка дає конкурентні переваги організації, забезпечуючи наступне:

- $\quad$ отримання переваг перед конкурентами при участі в тендерних торгах;

- підвищення іміджу організації в регіоні й галузі, а також в очах іноземних і вітчизняних партнерів і інвесторів;

- $\quad$ зниження непродуктивних витрат;

- $\quad$ забезпечення якості продукції та послуг будівельного підприємства;

- вдосконалення системи управління організації та підвищення іiі ефективності;

- $\quad$ підвищення відповідальності та дисциплінованості персоналу.

Усе вищеназване є актуальним для будівельних підприємств, оскільки вони безпосередньо пов'язують свою діяльність 3 тендерними торгами і отримати тендер на виробництво робіт - це першочергове завдання будівельної організації, яке в результаті забезпечує її прибутковість.

СМЯ $\epsilon$ основною складовою системи управління підприємством, i спрямована на забезпечення якості та ефективності діяльності всієї організації, шляхом забезпечення якості процесів організації, не тільки виробничих, але й управлінських та організаційних.

СМЯ будівельної продукції повинна будуватися на таких основних засадах як системний підхід, стандартизація, комплексне вирішення завдань раціонального обмеження, прямого i зворотного зв'язку, динамічності, оптимальності, інтеграції і модульної побудови, автоматизації та нових завдань. 
Принцип системного підходу передбачає необхідність управління якістю на всіх рівнях, розподіл процесів управління якістю на всі стадії життєвого циклу та охоплення всіх функцій управління стосовно керованого об'єкта.

Принцип стандартизації вказує на те, що всі основні вимоги до якості комплексної функції продукції та системи управління якістю повинні регламентуватися або забезпечуватися стандартами та нормативно- технічною документацією.

Принцип комплексного рішення передбачає комплексний підхід до проблеми якості кінцевої продукції та послуг будівництва.

Принцип раціонального обмеження передбачає постійну реалізацію ефекту фільтрації інформації для розгляду з усієї сукупності лише тих явищ, умов та факторів, які найбільшою мірою впливають на якість кінцевої продукції будівництва.

Принцип прямого і зворотного зв'язку припускає постійну взаємодію суб'єкта і об'єкта в системі управління на стадіях, таких як стадія контролю (одержання інформації та критична оцінка), стадія прийняття та реалізація рішень, наявність зв'язку між усіма елементами комплексної системи управління якістю.

Принцип оптимальності передбачає забезпечення вирішення поставлених завдань на основі вибору найкращого варіанта за мінімальних витрат на розробку системи та іiі функціонування.

Принцип динамічності передбачає безперервний процес вдосконалення системи управління якістю в процесі ії функціонування з урахуванням науковотехнічного прогресу, змін вимог нормативно-технічної документації та накопичувального досвіду.

Принцип інтеграції та модульної побудови вказує на те, що система менеджменту якістю повинна складатися 3 окремих модулів, які можуть розглядатися як самостійні системи, що діють на різних рівнях управління та життєвого циклу.

Таким чином, підсумовуючи вищезазначене, можна сказати, що розробка ефективної системи менеджменту якості на будівельному підприємстві $\epsilon$ необхідним кроком для досягнення його успішного функціонування на ринку у майбутньому. Але необхідно пам'ятати, що цей процес потребує не лише значних коштів, а й високого рівня професіоналізму тих працівників, які залучені до створення та підтримки функціонування даної системи у будівельній компанії.

\section{Список літератури}

1. Кононова О. О. Рівень ефективності стратегій розвитку будівельної галузі України. Проблеми і перспективи розвитку підприємництва. 2019. № 23. С. 74. URL: https://doi.org/10.30977/ppb.2226-8820.2019.23.0.74 (дата

звернення: 12.03.2021).

2. Калініченко Л. Л., Сидорова Ю. Р. Аналіз тенденцій розвитку будівельної галузі та будівельної продукції України. Молодий вчений. 2017. 4.4 (44.4). С. 64 
68. URL: http://molodyvcheny.in.ua/files/journal/2017/4.4/15.pdf (дата звернення: 04.04.2017)

3. Колесник А. В., Бутенко О. П. Аналіз стану та тенденцій розвитку ринку будівельних матеріалів України. Вісник економіки транспорту і промисловості. 2018. № 64. C. 141-151. URL: http://vetp.kart.edu.ua/index.php/ua/arhiv-nomeriv

4. Лучко Г.Й., Когут I. В. Актуальні проєкти стратегічного розвитку будівельної галузі України. Ефективна економіка. 2020. №. 8. URL: https://doi.org/10.32702/2307-2105-2020.8.65 (дата звернення: 12.03.2021)

5. ДСТУ ISO 9001-2001. Вид. офіц. Системи якості. Модель забезпечення якості в процесі проєктування, розроблення, виробництва, монтажу та обслуговування. 


\title{
НАУКОВА ДУМКА ЩОДО ДЕФІНІЩЇ̈ КАТЕГОРІЇ «ПІДРИСМНИЦЬКИЙ УНІВЕРСИТЕТ»
}

\author{
Грех Анастасія Сергіївна, \\ аспірант факультету економіки та бізнесу \\ Київського національного університету технологій та дизайну
}

Визначено передумови формування «підприємницького університету». Досліджено та систематизовано наукові підходи до дефініції категорії «підприємницький університет» за хронологією та однорідними ознаками. Проаналізовано світовий досвід становлення університетського підприємництва та визначено перспективи розвитку підприємницьких університетів в Україні.

The preconditions for the formation of an "entrepreneurial university" have been determined. Scientific approaches to the definition of the category "business university" by chronology and homogeneous features are researched and systematized. The world experience of formation of university business is analyzed and prospects of development of business universities in Ukraine are defined.

Ключові слова: заклад вищої освіти (ЗВО), підприємницький університет, університет третього покоління.

Key words: higher education institution, business university, third generation university.

Нові умови існування університетів поставили перед науковим i освітянським співтовариством питання про те, чи можна зберегти колишній спосіб роботи, заснований на державному фінансуванні вищої освіти, або ж слід пристосовуватися до нових умов сучасного світу. Саме тому необхідно систематизувати наукові підходи та розкрити сутність категорії «підприємницький університет», визначити та обгрунтувати перспективні напрями підприємницької діяльності українських університетів в глобальному освітньому середовищі.

Значний внесок у дослідження феномену університетського підприємництва і розвиток теорії «підприємницького університету» зробили Б. Кларк, Г. Іцковіц, Дж. Крісман, Т. Гінес, С. Фрейзер, Д. Ділл, Й. Рьопке, Г. Саботски, Д. Кірбі, М. Джакоб, М. Лундквіст, Х. Хелсмарк, Г. Вільямс, Г. Константинов, С. Філонович, О. Романовський, О. Моргулець, Н. Чухрай, та багато інших як іноземних, так і українських науковців. Вчені, як правило, в досліджували та визначали головні властиві підприємницьких університетів, їх риси й характеристики. Проте відсутнє єдине трактування дефініції категорії «підприємницький університет», що визначило завдання нашого дослідження - вивчити та систематизувати наукові підходи до цієї економічної категорії.

Вища освіта одна із найбільш динамічних, гнучких та адаптивних секторів економіки. Вона $\epsilon$ фундаментом розвитку національної економіки будь-якої 
країни, забезпечуючи тї висококваліфікованими фахівцями. Сучасним вітчизняним університетам доводиться конкурувати між собою та з іноземними університетами, що стимулює постійне формування конкурентних переваг, зміцнення іміджу на ринку освітніх послуг та залучення іноземних партнерів до освітньої та наукової діяльності університету. Зважаючи на ринково складову економічної діяльності закладів вищої освіти України розвиток засад підприємницької діяльності університетів стає неминучою умовою їхнього нинішнього функціонування та забезпечення успіху в майбутньому. Проте сьогодні підприємницька діяльність для більшості українських 3ВО $\epsilon$ недостатньо розвинутою i, подекуди, незрозумілою освітянам, тоді як для іноземних університетів це $є$ основний вид діяльності на рівні $з$ освітньою і науковою.

На сьогоднішній день відсутній єдиний, взаємно прийнятий підхід до тлумачення сутності підприємницького університету та основних його критеріїв і характеристик. Найбільший вклад у розвиток досліджуваної проблематики зробив американський вчений Б. Кларк [3], який вважається засновником першої наукової школи університетського підприємництва. Науковець грунтовно підійшов до аналізу сутності підприємницького університету, наголошуючи на доцільності розгляду підприємництва університетів і як процесу, і як результату. А саме як процес університетське підприємництво це - крок до спроможної системи освіти, який дасть позитивний результат на стадії формування освіченої робочої сили на вітчизняному та світовому ринках

Стенфордський вчений Г. Іцковіц під підприємницьким університетом розуміє заклад вищої освіти, що, окрім традиційних джерел фінансування, активно розробляє та використовує патенти, наукові дослідження та інші напрями договірного співробітництва 3 приватними підприємствами в якості дієвих інструментів розширення джерел фінансування та притоку інвестицій до університету [4]. Учений розуміє підприємницькі університети як своєрідні інкубатори підтримки та стимулювання бізнес-ініціатив співробітників і студентів ЗВО. Невід'ємною складовою місії сучасного університету, за Г. Іцковіцем, $є$ капіталізація знань.

Такі підходи до трактування сутності підприємницького університету $\epsilon$ цілком прийнятними, однак за умови їх наповнення сучасними достатньо диверсифікованими інструментами розширення підприємницьких функцій закладів вищої освіти.

Виключно 3 практичних аспектів сутність поняття «підприємницький університет» тлумачать Дж. Крісмен, Т. Хайнес і С. Фрейсер. На думку вчених, підприємницьким слід вважати університет, співробітники, викладачі, дослідники і студенти якого створюють нові підприємства [2]. Проте вважаємо, що створення самостійних підприємств сильно диверсифікую діяльність ЗВО і змінює акцент його основної діяльності - освітньо-наукової.

Обмеженим у контексті сучасного університетського підприємництва $\epsilon$ визначення Дж. Уїльямса, який пропонує розглядати університети «не більше 
як подавцями послуг у галузі знань» [9]. Університети, в першу чергу, є генераторами знань, i тільки потім їх продавцями.

Нинішні університети реалізують та демонструють значно ширший аспект підприємницької діяльності, що доводить Дж. Ропке [5]. Вчений розглядає три направлення підприємницьких університетів: по-перше, це університет, який виконує підприємницькі функції; по-друге, знаходить прояв у підприємницькій діяльності співробітників і студентів університетів; по-третє, стимулює розвиток кооперації із зовнішнім середовищем (зокрема, бізнес-сектором).

Подібної точки зору дотримується Дж. Субоцькі [6], наголошуючи на важливості глибокої співпраці підприємницьких університетів з бізнесом, у тому числі з позицій диверсифікації джерел фінансування вищої освіти та 3 наголосом на організацію адекватного підприємницького управління.

Комплексно пропонують розглядати сутність підприємницького університету російські науковці Г. Константинов і С. Філонович, які визначають єдність i актуальність наступних аспектів у діяльності підприємницьких університетів [1]:

- подолання бар'єрів при створенні знань та інновацій;

- забезпечення практичної цінності отриманих та генерованих в університеті знань (у першу чергу, завдяки інноваційній діяльності);

- оперативна модернізація ендогенного середовища підприємницьких університетів;

- трансформація напрямів взаємодії університетів із зовнішнім середовищем (за вектором підприємництва 3ВО).

У своїх дослідженнях Д. Ділл [7] відзначає прагнення університетів залучати додаткові фінансові ресурси завдяки капіталізації результатів наукових досліджень, під чим пропонує розуміти трансфер університетських технологій, що є ознакою підприємництва. При цьому науковець у своїй праці обгрунтовує важливість створення комерційних підприємств, на базі яких здійснюватиметься впровадження університетських розробок.

Д. Кірбі наголошує на тому, що в сучасних умовах університети перебувають у центрі підприємницької культури, власне перетворюючись у цих обставинах на підприємницькі університети [4]. Властивостями підприємницьких університетів, на думку науковці, $\epsilon$ ознаки, що характеризують будь-яку підприємницьку діяльність: інноваційність (розробка і впровадження новаціі), ризиковість (брати на себе ризики і нести відповідальність за прийняті рішення), адаптивність (оперативне підлаштування під зміни зовнішнього та внутрішнього середовища). Таким чином, науковець доводить об’єктивну обгрунтованість формування підприємницьких університетів як відповідь на виклики часу й динамічність ринкового середовища.

Структуру сутності підприємницького університету розглядають науковці М. Джейкоб, М. Люндквіст і Г. Хелсмарк [8]. 3 одного боку, основою підприємницького університету вони вбачають комерціалізацію освітніх та консультаційних послуг. 3 іншого боку, вчені акцентують увагу також на важливості реалізації університетами патентно-ліцензійної діяльності, 3 метою комерціалізації результатів наукових досліджень вчених, та діяльності 
з активізації підприємницької діяльності й ініціативності студентської молоді, наприклад, у вигляді стартапів.

Отже, на нашу думку підприємницький університет - це діяльність закладу вищої освіти спрямована забезпечення капіталізації знань та комерціалізації інновацій через співпрацю керівництва, науково-педагогічних працівників, здобувачів та бізнес-партнерів.

Досвід зарубіжних країн Україна може перейняти і впровадити з метою підвищення конкурентоспроможності та укріплення позицій закладів вищої освіти на світовому ринку освітніх послуг.

Сьогодні вітчизняне університетське підприємництво перебуває на етапі зародження, адже в країні наразі відсутні відповідні нормативно-правові акти, які б ідентифікували підприємницькі університети та державна підтримку, зокрема інвестування у розвиток українських наукових шкіл.

Крім того спостерігається значне загострення конкурентної боротьби між закладами вищої освіти як на вітчизняному, так і на світовому ринку освітніх послуг. Відтак необхідно розвивати напрямки підприємницької діяльності університетів, переймати кращий досвід зарубіжних закладів освіти, формувати нову освітню політику України та підприємницьку культуру ЗВО, спираючись на досвід розвинутих країн.

\section{Література:}

1. Константинов Г.Н. Что такое предпринимательский университет / Константинов Г.Н., Филонович С.Р. // Вопросы образования, 2007. - № 1. - С.4962.

2. Chrisman J. Faculty Entrepreneurship and Economic development: The Case of the University of Calgary / Chrisman J., Hynes T., Fraser S. // Journal of Business Venturing, July 1995. - Volume 10. - Is. 4. - p. 267-281.

3. Clark Burton R. Creating Entrepreneurial Universities: Organizational Pathways of Transformation. IAU PRESS. ISSUES IN HIGHER EDUCATION / Wagon Lane, Binglye BD16 1WA. - U.K.: Emerald Group Publishing Limited. Howard House, 2008.- 164 p.

4. Etzkowitz H. Research groups as \&apos;quasi firms\&apos;: the invention of the entrepreneurial university / Etzkowitz H. // Research Policy, 2003. -Vol. 32. - Is. 1. - p. 109-121.

5. Röpke J. The Entrepreneurial University, Innovation, academic knowledge creation and regional development in a globalized economy / Röpke J. // Working Paper Department of Economics, Philipps- Universität Marburg, Germany, 5.1.2000. - p. 3 (19 p.). [Electronic Resource]. Access mode: http://etc.online.unimarburg.de/LinkedDocuments/mafex_rj_entreuni.pdf
6.
Subotzky
$\mathrm{G}$.
Alternatives to the Entrepreneurial University: New Modes of Knowledge Production in Community Service Programs / Subotzky G. // Higher Education, December 1999. - Vol. 38. - No. 4. - Pp. 401-440.
7.
Dill
D.
University-industry entrepreneurship: the organization and management of American university technology transfer units. // Higher Education, 1995. - Vol. 29, No. 4. - Pp. 369-384. 
8. Jacob M., Lundqvist M., Hellsmark H. Entrepreneurial transformations in the Swedish University system:

the case of Chalmers University of Technology. // Research Policy, 2003. - Vol. 32. Is. 9. - Pp. 1555-1569.

9. Williams G.The Enterprising University: Reform, Excellence and Equity/ Edited by Gareth Williams. Buckingham [England]; Philadelphia, PA: Society for Research into Higher Education: Open University Press, 2003. - 193 p. 


\title{
ФОРМУВАННЯ КОНКУРЕНТНОЇ СТРАТЕГІЇ ЯК ЗАПОРУКА ПІДВИЩЕННЯ КОНКУРЕНТОСПРОМОЖНОСТІ СУЧАСНОГО ПІДПРИЕМСТВА
}

\author{
Кислякова Катерина, \\ здобувачка 4 курсу спец. 076 Підприємництво, \\ торгівля та біржова діяльність \\ Ізмаїльський державний гуманітарний університет \\ Метіль Тетяна Костянтинівна, \\ к.е.н., доц. кафедри управління підприємницькою \\ та туристичною діяльністю \\ Ізмаїльський державний гуманітарний університет
}

Жодна компанія не може досягти конкурентних переваг у всіх комерційних характеристиках товару та методах його просування на ринок. Необхідно вибрати пріоритети та розробити стратегію, яка найбільш відповідає тенденціям розвитку ринкової ситуації та найкращому використанню сильних сторін бізнесу. На відміну від тактичних дій на ринку, стратегія повинна бути спрямована на забезпечення конкурентних переваг у довгостроковій перспективі $[1$, c. 121$]$.

Конкурентна стратегія компанії включає підхід компанії до бізнесу та ініціативи, спрямовані на залучення клієнтів, конкуренцію та зміцнення іiі ринкових позицій.

Розглянемо, що розуміємо під поняттями «стратегія» та «конкурентна стратегія». За думкою I. Ансоффа: «Стратегія підприємства - це систематичний план його потенційної поведінки в умовах неповноти інформації про майбутній розвиток середовища та підприємництва, що включає формування місії, довгострокових цілей, а також шляхів і правил прийняття рішень для найбільш ефективного використання стратегічних ресурсів, сильних сторін і можливостей, усунення слабких сторін та захист від загроз зовнішнього середовища для майбутньої прибутковості» [2, с. 38]. Отже, необхідність розробки підприємствами стратегії викликана нестабільністю ринкового середовища, неповнотою інформації про його майбутній стан та вплив на підприємство. Тому потрібно підприємствам враховувати конкурентні стратегії, які враховують вимоги ринку та дають конкурентні переваги.

Конкурентна стратегія - спосіб довгострокових дій фірми в боротьбі 3 конкурентами, який грунтується на підвищенні якості товарів, зниженні витрат, диференціюванні продукту, проникненні на нові ринки з метою отримання конкурентних переваг [3, с. 38].

Система конкурентної стратегії компанії - це набір стратегій, до яких вона прагне при адаптації компанії до змін в умовах конкуренції та зміцнення іiі 
довгострокового характеру [4, с. 82]. Система конкурентних стратегій включає: стратегію отримання конкурентних переваг, стратегію конкурентоспроможності підприємств та стратегію їх конкурентної поведінки (рис. 1).

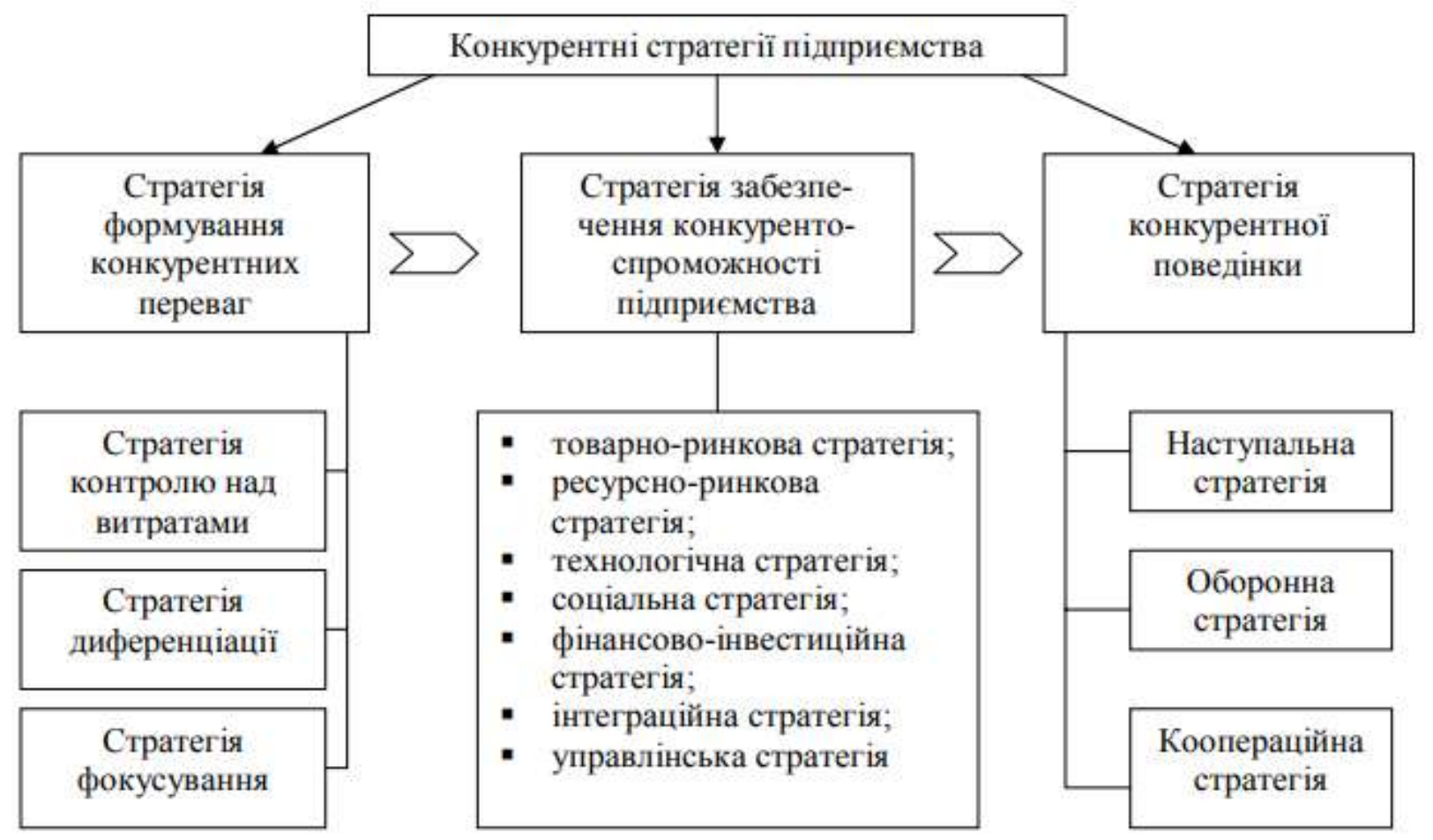

Рис. 1. Система конкурентних стратегій підприємства.

Стратегія конкуренції (див. табл. 1) передбачає як наступальні, так $\mathrm{i}$ захисні дії, що здійснюються залежно від ситуації на ринку [4, с. 52].

Таблиця 1

Основні стратегії конкуренції

\begin{tabular}{|c|c|}
\hline Конкурентні стратегії & Ключові конкурентні переваги \\
\hline зниження собівартості & низька собівартість і ціна товару \\
\hline диференціація продукції & $\begin{array}{c}\text { унікальність продукції, її висока якість та (або) } \\
\text { особливий дизайн }\end{array}$ \\
\hline сегментування ринку & $\begin{array}{c}\text { комплексне обслуговування сегментації } \\
\text { ринку для сегмента ринку }\end{array}$ \\
\hline впровадження інновацій & працює в новій ринковій ніші, де немає \\
& конкуренції \\
\hline негайне реагування на потреби ринку & $\begin{array}{c}\text { випередження конкурентів, завдяки більш } \\
\text { мобільній системі управління }\end{array}$ \\
\hline
\end{tabular}

Узагальнення теорії та практики конкуренції дозволяє виділити п'ять основних стратегій конкуренції, які мають певні переваги, але не позбавлені недоліків. Тому основна процедура відбору повинна спиратися на збалансовану оцінку сильних та слабких сторін кожної стратегії та реальних можливостей їх використання у сучасних ринкових умовах [5, с. 152].

Стимулом застосовування стратегії зменшення виробничих витрат $\epsilon$ значна економія на масштабі та залучення великої кількості споживачів, для яких ціна є вирішальним фактором придбання. Стратегія зосереджена на масовому 
виробництві стандартних товарів, яке, як правило, $є$ більш ефективним і вимагає менших одиничних витрат, ніж виробництво невеликих партій різнорідних товарів. У цьому випадку економія на змінних витратах досягається завдяки високій спеціалізації виробництва. Постійні витрати на виробничу одиницю, зменшуючись із збільшенням обсягу продажів, створюють додатковий резерв для зниження собівартості продукції.

Диверсифікація полягає у спеціалізації на виробництві спеціального (іноді нетипового) товару, який є модифікацією стандартного товару. Такі товари необхідні споживачам, якщо вони не задоволені стандартними товарами. Відокремлення товару на ринку та ширша диверсифікація його комерційних характеристик може відбуватися за рахунок продуктів з більш досконалими, ніж стандартні товари, технічними параметрами, якістю виготовлення, на основі надання більш широкого вибору послуг у сфері продажів та обслуговування продуктів на основі привабливості низьких цін. Основна ідея диференціації полягає в тому, щоб зосередитись на продуктах, на які існує обмежений попит, що дозволяє уникнути цінову конкуренцію з більш сильними виробниками, що реалізують стратегію економії коштів, дозволяючи їм конкурувати 3 ними за певні групи споживачів. Найбільш привабливим способом диференціації товарів $\epsilon$ використання технік, менш схожих на ті, що використовуються конкурентами.

Стратегія сегментації розроблена для забезпечення конкурентних переваг в окремому та часто однорідному сегменті ринку, який виділяється на основі географічних, психографічних, поведінкових, демографічних та інших принципів сегментації. Основна ідея полягає в тому, що компанія може обслуговувати свій вузький цільовий ринок ефективніше, ніж конкуренти, які розподілять свої ресурси на ринку. Як результат, конкурентна перевага виникає або через диференціацію товарів на основі більш повного задоволення потреб цільового ринку, або досягнення менших витрат на обслуговування обраного сегмента [2, с. 102].

Метою конкурентної стратегії $є$ пошук і позиціонування в галузі, де компанія найкраще захищена від впливу конкурентних сил або, в свою чергу, здатна впливати на нього. Тиск сукупної влади відчувають усі конкуруючі сторони, але для боротьби 3 ним стратегія повинна базуватися на ретельному аналізі походження кожного компонента [3, с. 56]. Тому пропонуємо алгоритм розробки конкурентної стратегії підприємства.

Етапи створення конкурентної стратегії включають [4, с. 87]:

Етап 1 - аналіз ринкової ситуації, що дозволяє характеризувати стан ринку, динаміку ринкових відносин, включаючи визначення обсягу виробництва на ринку, обсягу продажів, рівня цін на товари, кількості продавців, кількості покупців з метою визначення місткості ринку, підготовки прогнозу ринкової ситуації.

2 етап - аналіз конкурентного середовища компанії, що дозволить визначити, до яких ринкових структур належить досліджуваний об'єкт, оцінити ступінь розвитку або нерозвиненості конкуренції на ньому.

3 етап - оцінка сильних і слабких сторін компанії, що включає: аналіз внутрішнього потенціалу компанії, аналіз зовнішнього середовища компанії, 
аналіз внутрішнього середовища компанії, який спільно виявить сильні та слабкі сторони компанії компанія.

4 етап - аналіз конкурентних переваг компанії, що передбачає пошук конкурентних переваг компанії, які можуть бути основою конкурентної стратегії компанії. Конкурентна перевага може бути досягнута в кожній з трьох основних сфер:

- $\quad$ надання більших переваг, продаж дешевших товарів;

- $\quad$ виправдання високих цін підвищеною або оригінальною якістю та послугою;

- $\quad$ задоволення специфічних потреб вузької групи споживачів.

5 етап - вибір конкурентної стратегії. Після проведення аналізу, зібраного на попередніх етапах, керівники компанії роблять вибір базової стратегії конкуренції.

Крок 6 - розробка конкурентних альтернатив та розрахунок їх ефективності.

Отже, на основі вищезазначеного можна стверджувати, що конкурентна перевага компанії відображається в іiі здатності краще задовольняти потреби цільових ринків, ніж ії конкурентів.

Джерела конкурентних переваг різноманітні: забезпечення виробництва високоякісної продукції; досягнення мінімального рівня витрат порівняно 3 конкуренцією; вигідне географічне розташування; надання споживачам широкого спектру додаткових послуг тощо. Усі ці переваги зводяться до переконання покупця в тому, що він отримує більше вигоди від споживання продукції та послуг компанії порівняно з аналогічними товарами конкурентів. Вибір конкретної конкурентної стратегії компанією значною мірою залежить від досягнення компанією конкурентної переваги, яку вона здатна забезпечити та підтримувати протягом тривалого часу в ході конкуренції.

\section{Література:}

1. Портер М. Конкуренция. Пер. с англ. М.: Вильямс, 2005. 608 с.

2. Должанський I. 3. Конкурентоспроможність підприємства. К.: Центр навчальної літератури. 2006. 384 с.

3. Іванов Ю. Б., Орлов П. А., Іванова О. Ю. та ін. Конкурентні переваги підприємства: оцінка формування та розвиток: монографія. Х.: ВД «ІЖЕК», 2008. $352 \mathrm{c}$.

4. Берницька Д.І. Стратегія підприємства. Навчальний посібник. Тернопіль. 2012. с. 231 c. 


\title{
НЕФІНАНСОВА (СОЦАЛЬНА) ЗВІТНІСТЬ ПІДПРИЄМСТВ ТА ЦЛІ СТАЛОГО РОЗВИТКУ
}

\author{
Кононенко Леся Віталіївна \\ кандидат економічних наук, доцент \\ доцент кафедри аудита, обліку та оподаткування \\ Центральноукраїнський національний технічний університет

\section{Юрченко Оксана Володимирівна} \\ асистент кафедри аудита, обліку та оподаткування \\ Центральноукраїнський національний технічний університет
}

Еволюція людської цивілізації це хвилеподібний (циклічний) розвиток. Кожна хвиля (цикл) охоплює повну організаційну еволюцію структури: їі виникнення, відносно стійке існування і розпад. Виникнення організаційноеволюційної структури завжди пов'язано із інноваціями, які, як правило, виникають майже одночасно у різних сферах. При цьому інновації у одній сфері призводять до інновацій у інших, що дозволяє отримати синергетичний ефект. Так, початок Промислової революції (1780-1851рр.) пов’язують із розвитком промислової та металургійної галузей. Проте, саме у цей час набув поширення подвійний бухгалтерський запис, масове використання якого дозволило суттєво підвищити якість інформації, яка формувалась у обліковій інформаційній системі. Це дало можливість забезпечити управлінців якісною інформацією, що, у свою чергу, дозволило їм приймати адекватні управлінські рішення, що призвело до росту як економіки в цілому, так і iі окремих галузей (сфер). Основним джерелом інформації для користувачів (особливо зовнішніх) $\epsilon$ звітність. Отже, «формування достовірної i повної інформації на рівні підприємства ...для...менеджерів усіх рівнів відбувається саме у бухгалтерській інформаційній системі» [1], а кінцевим «продуктом» цієї системи є звітність.

Сучасна світова економіка характеризується переходом на модель сталого розвитку, яка передбачає врахування економічної, соціальної та екологічної складових. Це обумовлює необхідність отримання інформації щодо впливу діяльності суб'єктів господарювання на економіку, екологію та соціальну сферу. Якщо економічні показники знаходять своє відображення у фінансовій звітності, то показники екологічної та соціальної діяльності у ній не відображаються. Отже, виникає необхідність формування нефінансової звітності, показники якої дозволять задовольнити запити користувачів щодо соціальної та екологічної відповідальності бізнесу в умовах сталого розвитку [2, 3, 4, 5].

Питання формування нефінансової звітності підприємств $є$ предметом дослідження багатьох вітчизняних і закордонних вчених. Так, Ловінська Л. Г. досліджувала нефінансову звітність як основу інформаційного забезпечення моніторингу досягнення Цілей сталого розвитку [6]. Праці Камінської І. Б. присвячені дослідженню економічної сутності дефініції «нефінансова (соціальна) звітність підприємств» [7]. Напрацювання Легенчука С. Ф. 
присвячені розробці перспектив розвитку механізму розкриття фінансових та нефінансових показників в інтегрованій звітності [8]. Однак, не зменшуючи вагомості внеску вчених щодо дослідження даної проблематики, питання формування нефінансової (соціальної) звітності підприємств набувають все більшої актуалізації в сучасних умовах господарювання.

3 метою досягнення Цілей сталого розвитку на рівні світового суспільства у 2015 році на Саміті ООН було прийнято Порядок денний ООН у сфері сталого розвитку до 2030 року [9]. Прийнятий документ містить основні положення щодо об'єднання зусиль світового суспільства 3 метою формування глобальної політики у вимірах сталого розвитку (економічного, соціального та екологічного). Зазначені положення були адаптовані до реалій України шляхом прийняття 30 вересня 2019 року Указу Президента України «Про Цілі сталого розвитку України на період до 2030 року» [10]. Проте їх реалізація неможлива без адекватного інформаційного забезпечення, тобто без використання (а отже і без формування) нефінансової (соціальної) звітності підприємствами. Але, незважаючи на наявність «понад два десятки визнаних міжнародних рекомендацій із питань складання нефінансової звітності», не розроблено універсального нормативного документа зі стандартизації нефінансової звітності, що 3 одного боку унеможливлює інформаційне забезпечення моніторингу досягнень Цілей сталого розвитку, а з іншого - виконавці цих досягнень не мають якісного інформаційного забезпечення для їх виконання.

Більшість вітчизняних підприємств сьогодні не формують і не подають нефінансову звітність. Отже, з метою досягнення Цілей сталого розвитку необхідно:

імплементувати норми світового законодавства щодо необхідності формування і подання нефінансової (соціальної) звітності;

розробити нормативно-методичне забезпечення щодо формування $\mathrm{i}$ подання нефінансової (соціальної) звітності.

Таким чином, одним із шляхів досягнення Цілей сталого розвитку $\epsilon$ формування і використання нефінансової (соціальної) звітності. Як у свій час винахід і масове використання подвійного запису сприяло початку Промислової революції, так і застосування нефінансової (соціальної) звітності забезпечить досягнення Цілей сталого розвитку. Все вищезазначене є напрямом подальших досліджень.

\section{Список літератури:}

1. Кононенко Л. В. Інноваційний розвиток системи бухгалтерського обліку як інформаційного забезпечення діяльності підприємства. Наукові пращі Кіровоградського національного технічного університету. Економічні науки: зб. наук. пр. Кропивницький: ЦНТУ, 2018. Вип. 33. С. 144-152. (дата звернення: 21.02.2021).

2. Khaustova Yevheniia, Akmal Durmanov, Dubinina Maryna, Yurchenko Oksana, Cherkesova Elvira. Quality of strategic business management in the aspect of growing the role of intellectul capital. Academy of Strategic Management Journal. Volume 19. Issue 5, 2020. URL: https://search.proquest.com/openview/94acda 

звернення: 13.02.2021).

3. Savchenko Vera, Gai Oleksandr, Yurchenko Oksana. Accounting theories and their impact on the formation and development of social expenditure accounting. Центральноукраӥнський науковий вісник. Економічні науки. 2020. Вип. 4(37). С. 251-258. URL: http://economics.kntu.kr.ua/pdf/4(37)/25.pdf (дата звернення: 12.02.2021).

4. Кононенко Л.В., Юрченко О.В. Социальная составляющая интегрированной отчетности. The VIII International Science Conference «Problems and tasks of modernity and approaches to their solution», March 02 - 05, 2021, Tokyo, Japan. $\quad$ Pp. $43 \quad$ - $46 \quad$ URL: https://books.google.com.ua/books?hl=en\&lr=\&id=4AAiEAAAQBAJ\&oi=fnd\&pg= PA43\&dq=info:BTmBRmHADt0J:scholar.google.com\&ots=3O4pZOBoi_\&sig=3Z1 U_URdOiu7sjAmiDls_8yMn4A\&redir_esc=y\#v=onepage\&q\&f=false (дата звернення: 09.03.2021).

5. Юрченко О.В. Звітність в системі управління соціальними витратами. Вісник Бердянського університету менеджменту і бізнесу. 2011. № 2(14). URL: http://dspace.kntu.kr.ua/jspui/bitstream/123456789/5848/1/zvitnist_v sistemi_upravlinnya_socialnimi_vitratami.pdf (дата звернення: 22.02.2021).

6. Ловінська Л. Г. Нефінансова звітність як основа інформаційного забезпечення моніторингу досягнення Цілей сталого розвитку. Фінанси Украӥни. 2019. № 11. C. 20-30. URL: http://nbuv.gov.ua/UJRN/Fu_2019_11_4

7. Камінська І. Б. Нефінансова (соціальна) звітність підприємств. Науковий вісник Івано-Франківського національного технічного університету нафти $i$ газу. Серія : Економіка та управління в нафтовій і газовій промисловості. 2019. № 2. C. 154-161. URL: http://nbuv.gov.ua/UJRN/nvifnunge_2019_2_16 (дата звернення: 21.02.2021).

8. Легенчук С. Ф. Механізм розкриття фінансових та нефінансових показників в інтегрованій звітності: перспективи розвитку. Держава та регіони. Серія : Економіка та підприємництво. 2019. № 4. C. 184-188. - URL: http://nbuv.gov.ua/UJRN/drep_2019_4_34 (дата звернення: 23.02.2021).

9. Transforming our world: the 2030 Agenda for Sustainable Development: Resolution A/RES/70/1 adopted by the General Assembly / United Nations. 2015, Sept. 25. URL: http:// sd4ua.org/wp-content/uploads/2015/02/SD _resolution_NY_2015.pdf. (дата звернення: 21.02.2021).

10. Про Цілі сталого розвитку України на період до 2030 року: Указ Президента України від 30 вересня 2019 року №722/2019. URL: https://www.president.gov.ua/documents/7222019-29825 (дата звернення: 21.02.2021). 


\section{МОДЕРНІЗАЦІЯ ТРАНСПОРТНОЇ ІНФРАСТРУКТУРИ ЯК ПРІОРИТЕТ НАЦІОНАЛЬНОЇ ЕКОНОМІКИ НІМЕЧЧИНИ}

\section{Осадча Наталія Вікторівна}

д.е.н., доцент

\section{Трушкіна Наталія Валеріївна}

к.е.Н.

Інститут економіки промисловості НАН України (м. Київ)

Ключовим пріоритетом національної економіки Німеччини визнано модернізацію транспортної інфраструктури, яка має стратегічне значення у забезпеченні збалансованого сталого розвитку країни. Для цього є об'єктивні передумови. Німеччина має вигідне економіко-географічне, логістичне й транзитне положення. У країні функціонує розвинута мережа транспортної інфраструктури, до якої входить автомобільний, залізничний, повітряний, водний (морський, річковий і озерний), трубопровідний транспорт, а також громадський транспорт пасажирських перевезень.

Географічне положення Німеччини дозволяе контролювати сухопутні, річкові й повітряні транспортні шляхи між країнами Західної, Північної, Центральної та Східної Свропи, морські транспортні коридори між акваторіями Балтійського і Північного морів (Кільським каналом).

Bce це сприятиме підвищенню рівня транзитного потенціалу [1-3], раціональній організації логістичної діяльності на засадах кластеризації [4-7], оптимізації руху транспортних потоків, мінімізації логістичних витрат [8-10], зміцненню конкурентних позицій на європейському та світовому ринках транспортно-логістичних послуг.

Слід зазначити, що відповідно до досліджень Світового банку за 20122018 рp. [11] Німеччина має найвищий індекс ефективності логістики. Так, у світовому рейтингу Німеччина посіла в 2018 р. 1-е місце серед 160 країн світу. У 2012 р. країна була на 4-му місці серед 167 країн світу. При цьому за період 20122018 рр. спостерігається позитивно стабільна тенденція позицій країни в рейтингу за основними індикаторами. Майже за всіма показниками Німеччина $\epsilon$ лідером. Лишу за індикатором «Простота організації міжнародних вантажоперевезень» вона посіла 4-е місце після Бельгії (1-е), Швеції (2-е), Австрії (3-е місце). За індикатором «Відстеження постачань» Німеччина зайняла 2-е місце, поступаючись Фінляндії. За індикатором «Своєчасність постачань» Німеччина має 3-ю позицію після Бельгії (1-а) і Данії (2-га) (табл. 1). 
Таблиия 1

Оцінка Німеччини в рейтингу ефективності логістики за 2012-2018 pp.

\begin{tabular}{|l|c|c|c|c|}
\hline \multirow{2}{*}{ Індикатори } & \multicolumn{4}{c|}{ Роки } \\
\cline { 2 - 5 } & \multicolumn{2}{|c|}{2018} & \multicolumn{2}{c|}{$2012-2018$} \\
\cline { 2 - 5 } & Ранг & Бали & Ранг & Бали \\
\hline Якість інфраструктури & 1 & 4,37 & 4 & 4,38 \\
\hline Простота організації міжнародних вантажоперевезень & 4 & 3,86 & 4 & 3,83 \\
\hline Ефективність роботи митниці & 1 & 4,09 & 1 & 4,09 \\
\hline Якість логістики та компетентність & 1 & 4,31 & 1 & 4,26 \\
\hline Відстежування постачань & 2 & 4,24 & 1 & 4,22 \\
\hline Свосчасність постачань & 3 & 4,39 & 1 & 4,40 \\
\hline Індекс ефективності логістики & 1 & 4,20 & 1 & 4,19 \\
\hline
\end{tabular}

Складено за даними: [11].

Як показує статистичний аналіз, обсяги вантажоперевезень залізничним транспортом у Німеччині збільшилися за 2000-2018 рр. на 42,2\%, автомобільним - на 6,5\%. Однак обсяги перевезення вантажів річковим транспортом скоротилися на $18,3 \%$. Аналогічна ситуація у країні спостерігається і 3 показником вантажообігу. Так, вантажообіг залізничного транспорту зріс на $69,8 \%$, автомобільного - на 12,8\%. Вантажообіг річкового транспорту зменшився на 29,4\% (табл. 2).

Таблиия 2

Динаміка обсягів перевезень вантажів і вантажообіг за видами транспорту

\begin{tabular}{|l|c|c|c|c|c|c|}
\hline \multirow{2}{*}{ Роки } & \multicolumn{2}{|c|}{ Вантажоперевезення, тис. $m$} & \multicolumn{3}{c|}{ Вантажообіг, млн ткм } \\
\cline { 2 - 7 } & залізничний & автомобільний & річковий & залізничний & автомобільний & річковий \\
\hline 2000 & 282861 & 3005104 & 242223 & 75884 & 280699 & 66465 \\
\hline 2005 & 321343 & 2764983 & 236765 & 91601 & 310114 & 64096 \\
\hline 2010 & 355715 & 2734605 & 229607 & 107317 & 313104 & 62278 \\
\hline 2013 & 373738 & 2938702 & 226864 & 112613 & 305744 & 60070 \\
\hline 2014 & 365003 & 3052628 & 228489 & 112629 & 310142 & 59093 \\
\hline 2015 & 367314 & 3035329 & 221369 & 116632 & 314816 & 55315 \\
\hline 2016 & 360712 & 3111819 & 221349 & 117333 & 315769 & 54347 \\
\hline 2017 & 376006 & 3161781 & 222731 & 125162 & 313143 & 55518 \\
\hline 2018 & 402261 & 3200890 & 197904 & 128816 & 316766 & 46901 \\
\hline
\end{tabular}

Представлена наявна інформація із статистичної бази даних Європейської економічної комісії $\mathrm{OOH}$.

Складено за даними: [12, с. 144-145, 147-149; 13, с. 104, 107, 108, 110].

Разом 3 тим, варто зазначити, що на даний час в ООН розглядають способи скорочення негативного впливу вантажних перевезень на природу. Одним 3 них, як вважають в Європейській економічній комісії $\mathrm{OOH}$, може бути диверсифікація перевезень внутрішніми водними шляхами. Збільшення обсягів перевезення вантажів річковим транспортом обумовлено основними положеннями Паризької угоди в рамках Рамкової конвенції ООН про зміну клімату щодо регулювання заходів із зменшенням у світі викидів діоксиду вуглецю. В ООН пропонують країнам світу (у тому числі й Німеччині, у якій частка вантажних перевезень внутрішніми водними шляхами складає понад $10 \%)$ приділити більше уваги розвитку водного транспорту як найвигіднішого 3 
економічної точки зору і безпечнішого з екологічної. За даними Європейської економічної комісії, в останнє десятиліття спостерігається тенденція до збільшення розмірів суден при скороченні їх числа. Модернізація портової інфраструктури, розширення мережі маршрутів вантажоперевезень дозволять створити нові робочі місця, забезпечити сталий розвиток транспортної сфери.

Отже, з точки зору підвищення ефективності транспортної логістики (особливо річкової) та управління ланцюгами постачань доцільно здійснювати модернізацію транспортної інфраструктури як складової національної транспортно-логістичної системи Німеччини. Наприклад, у 2019 р. уряд інвестував 17 млрд євро у розвиток транспортної інфраструктури. У 2020 р. загальні витрати державного бюджету становили 362 млрд євро, з яких 42,9 млрд на ремонт транспортної інфраструктури. Це 11,9\% загального обсягу витратної частини бюджету країни.

У 2020 р. після підписання угоди LuFV III з Міністерство транспорту та цифрової інфраструктури Німеччини (BMVI) [14] про цільові показники продуктивності і фінансування на загальну суму 86,2 млрд євро протягом найближчих 10 років залізниці Німеччини (DB) оголошено про плани інвестувати 12,2 млрд євро у розвиток інфраструктури. Це на 1,5 млрд євро перевищує загальний розмір коштів, виділених у 2019 р. DB має оновити 1800 км шляхів і понад 1900 стрілочних переводів, а також реконструювати 160 мостів і модернізувати 800 станцій. Крім коштів у рамках угоди LuFV III, інвестиції будуть надходити 3 державного бюджету, які виділяються на реконструкцію $\mathrm{i}$ нове будівництво залізниць, поліпшення транспортної доступності тощо. Власні кошти DB у складі цих інвестицій складатимуть 2,4 млрд євро. Вони будуть спрямовані на утримання і ремонт інфраструктури.

При цьому BMVI запустило нову програму, загальною вартістю понад 5 млрд євро [15]. Її мета полягає в створенні на залізничних станціях малого і середнього розміру безбар'єрного середовища i зручностей для пасажирів, включаючи влаштування пандусів, ліфтів, оновлення інформаційних покажчиків. Організацією робіт займеться німецький державний залізничний оператор Deutsche Bahn. Зокрема, на реконструкцію 111 малих станцій (3 пасажиропотоком менше 1000 осіб на день) виділено 330 млн євро. 50 станцій середнього розміру отримають до 2026 р. 140 млн євро. На модернізацію вокзальних будівель на 40 станціях з пасажиропотоком до 50 тис. осіб на день BMVI планує інвестувати 142 млн євро, а 50 млн євро витратять DB за рахунок власних коштів.

До того ж Deutsche Bahn i BMVI запланували реалізацію проєкту, спрямованого на створення цифрового залізничного вузла в Штутгарті. До 2025 р. компанія має оснастити цифровою сигналізацією всі станції і близько 100 км шляхів у Штутгарті, а також системами управління залізничним рухом i автоматизації поїздів.

Виходячи $з$ вищевикладеного, можна дійти такого висновку. Транспортнологістичну систему Німеччини визнано передовою в усьому світі. Уряд країни приділяє значну увагу організації комбінованих перевезень, 3 огляду на зростаючі обсяги переміщених вантажів. Основними завданнями в транспортній 
сфері $є$ перехід з автомобільного на залізничний транспорт, скорочення викидів від вантажних перевезень, відсутність негативного впливу на клімат у зв'язку із зростанням транспортних потоків, необхідність розподілу глобальних i регіональних потоків товарів.

Таким чином, розвиток інтегрованої транспортно-логістичної системи на засадах мультимодальності у Німеччині, яка б відповідала сучасним умовах глобалізації, сприяє підвищенню рівня конкурентоспроможності, залученню додаткових інвестицій у транспортну й логістичну сфери, зростанню обсягів міжнародних перевезень за рахунок довгострокового сталого партнерства між учасниками ринку транспортно-логістичних послуг.

У подальших дослідженнях планується надати пропозиції щодо можливості застосування досвіду Німеччини 3 питань модернізації транспортної інфраструктури у сучасних умовах національної економіки України.

\section{Список літератури:}

1. Осадча Н.В. Формування глобальних інститутів регулювання митної справи: монографія. Дніпропетровськ: Нова ідеологія, 2013. 320 с.

2. Ляшенко B.I., Осадча Н.В., Трушкіна Н.В. Транзитний потенціал Придніпровського економічного району: особливості та тенденції розвитку. About the problems of science and practice, tasks and ways to solve them: Abstracts of VI International scientific and practical conference (October 26-30, 2020). Italy, Milan: International Science Group, 2020. P. 111-116.

3. Ляшенко В. І., Осадча Н. В., Трушкіна Н. В. Інституційні умови підвищення ефективності використання транзитного потенціалу Придніпровського економічного району. Науковий вісник Ужгородського національного університету. Сер.: Міжнародні економічні відносини та світове господарство. 2020. Вип. 34. С. 137-146. https://doi.org/10.32782/24139971/2020-34-23.

4. Trushkina N. Improving the efficiency of the transport and logistics system in the context of sustainable development: the EU experience [Підвищення ефективності функціонування транспортно-логістичної системи в контексті сталого розвитку: досвід ЄC]. Territories' development: social, economic and humanitarian issues: monograph / Edited by T. Nestorenko, S. Sliwa; The Academy of Management and Administration in Opole. Opole: Publishing House WSZiA, 2019. P. 142-149.

5. Trushkina N. European experience in the development an integrated transport and logistics system [Европейский опыт развития интегрированной транспортнологистической системы]. Research and Practice: collection of scientific articles (Paris, September 27, 2019). Lardy Publishing House, Paris, France, 2019. P. 39-43.

6. Ляшенко В.І., Іванов С.В., Трушкіна Н.В. Транспортно-логістичний кластер як елемент регіональної інноваційної інфраструктури Придніпровського економічного району. Latest Technologies of Neo-industrial Transformations: Financial, Legal and Sociological Aspects: Collective monograph / L. Gutsalenko, 
V. Liashenko, O. Sukach and others; ed. by Yu. Pasichnyk. Austria, Steyr: Shioda GmbH, 2020. P. 220-231.

7. Іванов С.В., Ляшенко В.І., Трушкіна Н.В. Правові аспекти створення транспортно-логістичних кластерів в регіонах України. Gesellschaftsrechtliche Transformationen von wirtschaftlichen Systemen in den Zeiten der NeoIndustrialisierung: Collective monograph / Akademie der Wirtschaftswissenschaften der Ukraine. Nüremberg: Verlag SWG imex GmbH, 2020. S. 661-668.

8. Trushkina N., Rynkevych N. Optimization of information flows in transport logistics [Оптимизация информационных потоков в транспортной логистике]. Contemporary issues of sustainable development: monograph / Edited by T. Pokusa, O. Nestorenko. Opole: The Academy of Management and Administration in Opole, 2019. P. 137-146.

9. Trushkina N., Shkrygun Yu. Analytical assessment of the current state and trends of logistics activity of automobile companies in Ukraine [Аналітична оцінка сучасного стану й тенденцій розвитку логістичної діяльності автомобільних компаній в Україні]. The role of technology in the socio-economic development of the postquarantine world: monograph / Edited by M. Gawron-Łapuszek, A. Karpenko. Katowice: Publishing House of Katowice School of Technology, 2020. P. 310-318.

10. Трушкіна Н. В., Шкригун Ю. О. Актуальні проблеми логістичної діяльності автомобільних компаній Німеччини. Actual trends of modern scientific research: Abstracts of V International Scientific and Practical Conference (Munich, Germany, November 8-10, 2020). Munich: MDPC Publishing, 2020. P. 531-538.

11. Connecting to Compete 2018. Trade Logistics in the Global Economy. The Logistics Performance Index and Its Indicators / J.-F. Arvis, 1. Ojala, C. Wiederer, B. Shepherd, A. Raj, K. Dairabayeva, T. Kiiski. Washington, DC, The International Bank for Reconstruction and Development, The World Bank, 2018. 82 p.

12. Транспорт і зв'язок України за 2018 рік: стат. збірник. Київ: Державна служба статистики України, 2019. 154 с.

13. Транспорт України за 2019 рік: стат. збірник. Київ: Державна служба статистики України, 2020. 115 с.

14. В 2020 году инвестиции в инфраструктуру железных дорог Германии превысят 12 млрд евро. 2020.230 января. URL: http://www.zdmira.com/news/v2020goduinvesticiivinfrastrukturuzeleznyhdorogge rmaniiprevysat 12 mlrdevro.

15. В Германии запускают масштабную программу по модернизации ж/д станций стоимостью 5 млрд евро. Центр транспортных стратегий. 2021. 5 марта. URL: https://cfts.org.ua/news/2021/03/05/v_germanii_zapuskayut_ masshtabnuyu_programmu_po_modernizatsii_zh_d_stantsiy_stoimostyu_5_mlrd_ evro_63658. 


\title{
МОБИЛИЗАЦИЯ СБЕРЕЖЕНИЙ В ИНВЕСТИЦИИ ПУТЕМ ПАЕВЫХ ИНВЕСТИЦИОННЫХ ФОНДОВ
}

\author{
Рябова Надежда Николаевна \\ магистр экономики, старший преподаватель \\ кафедра «Финансы» \\ Таразский региональный университет им. М.Х.Дулати
}

Под сбережениями понимают разницу между доходами населения и его текущими расходами, как сумму денежных средств, оставшуюся не потребленной в настоящем времени. Также под сбережениями понимается та часть дохода, которую экономический субъект собирается потребить в будущем вместо того, чтобы потребить ее в настоящем. Различают три вида экономических субъектов: население, корпорации и государство. Соответственно возникают три вида сбережений: сбережения населения, сбережения корпоративного сектора, сбережения государства. Население традиционно является основным поставщиком инвестиционных ресурсов, мобилизация сбережений населения является для финансовых посредников важнейшим условием успешной деятельности. Средства, не потребленные в текущем периоде, приобретают три основные формы: вклады в коммерческие банки и ценные бумаги, валютные сбережения, денежные остатки на руках [1].

Эффективно работающий рынок служит основным поставщиком инвестиционных ресурсов в реальный сектор экономики. Рынок ценных бумаг является важнейшим механизмом рыночной экономики.

Коллективное инвестирование позволяет объединить средства мелких инвесторов на фондовом рынке и выступать элементом системы механизмов мобилизации сбережений и трансформации их в инвестиции для реального сектора экономики [2].

Коллективное инвестирование - схема инвестирования, при которой средства, вложенные мелкими инвесторами, аккумулируются в единый фонд под управлением профессионального менеджера для их последующего вложения с целью получения прибыли (прироста).

Таким образом, коллективное инвестирование предполагает создание фонд суммы денежных средств из средств мелких вкладчиков, который потом будет инвестироваться в ценные бумаги, недвижимость или какие-то другие активы.

На рынке ценных бумаг коллективное инвестирование, с одной стороны, выступает как посредник между мелкими вкладчиками и субъектами рынка, с другой стороны, при реализации функции управления активами коллективные инвесторы сами становятся субъектами рынка, вступая в определенные отношения по поводу обращения ценных бумаг [3].

Потребность в эффективном механизме превращения сбережений в инвестиции может быть решена с помощью финансовых посредников. Потенциальными источниками долгосрочных ресурсов, мобилизуемых для финансирования проектов развития, могут стать институты коллективного 
инвестирования - страховые компании, паевые инвестиционные, общие фонды банковского управления и негосударственные пенсионные фонды.

Рынок коллективных инвестиций - рынок, реализующий схему инвестирования, при которой несколько участников, которые могут быть частными лицами или крупными компаниями, вкладывают свое имущество в единый фонд под управлением профессионального управляющего для их последующего вложения с целью получения прибыли.

Все инвесторы подразделяются на индивидуальных и институциональных.

Регулирование деятельности институциональных инвесторов в нашей стране в настоящее время делегировано Национальному банку РК.

Одним из путей привлечения сбережений населения стало развитие институциональной инфраструктуры в виде паевых инвестиционных фондов (ПИФ), способных формировать пулы денежных средств и размещать их в краткосрочные финансовые инструменты. Для институтов коллективного инвестирования характерна сложная система рисков. Выделяет несколько видов риска взаимных фондов: процентный риск, кредитный риск, риск доходности, инфляционный риск, риск «события», налоговый риск, валютный риск и риск, связанный с менеджментом.

ПИФ - аккумулирует средства частных инвесторов и вкладывает эти средства в различные инструменты финансового рынка. Полученный доход или убыток распределяется среди всех пайщиков пропорционально их первоначальному взносу. Доход пайщика - прирост стоимости пая. ПИФы осуществляют вклады в объекты, наиболее выгодные для инвесторов: недвижимость, банковские депозиты, ценные бумаги.

Наиболее популярными на рынке ПИФов являются открытые инвестиционные фонды. Деятельность паевых фондов ориентирована на стабилизацию рынка, сокращение рисков, повышение устойчивости всей финансовой среды.

В Казахстане по состоянию на 01.01.2021г. на рынке ценных бумаг действует 35 паевых инвестиционных фондов, из которых 20 интервальных, 14 закрытых и 1 открытый. Совокупный объем активов под управлением на рынке коллективных инвестиций на конец декабря 2020 года составил 234 млрд. тенге и в сравнении с предыдущим месяцем увеличился на 42,3 млрд. тенге или на 22\% (за 2020 год - увеличение на 106\% или 120,6 млрд. тенге). Данное увеличение произошло, прежде всего, за счет положительной переоценки ценных бумаг, находящихся в составе активов паевых инвестиционных фондов и привлечения активов инвесторов, путем размещения паев инвестиционных фондов. [4]. На конец декабря 2020 года основным активом паевых инвестиционных фондов попрежнему остается портфель ценных бумаг (84\% от совокупных активов), при этом 99\% портфеля состоит из ценных бумаг, выраженных в иностранной валюте.

По состоянию на 01.01.2021г. ценные бумаги эмитентов-нерезидентов в портфеле паевых инвестиционных фондов составили 172 млрд. тенге или 74\% от совокупных активов, эмитентов-резидентов РК - 12,2 млрд. тенге или 5\% от совокупных активов, представленные в основном еврооблигациями АО 
«Народный Банк Казахстана» и АО «Банк ЦентрКредит». Также в составе активов имеются паи зарубежных инвестиционных фондов в размере 6,1 млрд. тенге или $3 \%$ от совокупных активов.

Денежные средства на текущих счетах на 01.01.2021г. составили 27,8 млрд. тенге или $12 \%$ от совокупных активов. Дебиторская задолженность в активах паевых инвестиционных фондов составила 5,5 млрд. тенге. Данная дебиторская задолженность возникла в связи с частичным погашением 31 декабря 2020 года облигаций АО «Народный Банк Казахстана».

Из-за волатильности курса национальной валюты, а также низких ставок по валютным депозитам со стороны инвесторов сохраняется спрос на паи инвестиционных фондов, инвестиционная стратегия которых предусматривает приобретение валютных активов. Количество держателей паев на 01.01.2021г. составило 1450 физических лиц и 57 юридических лиц, из которых 48\% составляют держатели паев валютных инвестиционных фондов. В сравнении с предыдущим месяцем количество держателей паев увеличилось на 158 (149 физических лиц и 9 юридических лиц). За 2020 год по сравнению с 2019 годом количество держателей паев увеличилось на 435 (413 физических лиц и 22 юридических лица).

Банки второго уровня, в депозиты которых размещаются паи паевого инвестиционного фонда до окончания срока их первоначального размещения, должны соответствовать условиям: 1) не должны являться аффилированными по отношению к управляющей компании данного паевого инвестиционного фонда; 2) ценные бумаги банков второго уровня должны быть включены в категории списка фондовой биржи [5].

Главными преимуществами коллективного инвестирования являются:

- профессиональное управление. Компании, занимающиеся финансовыми инвестициями, с большей вероятностью обладают необходимыми знаниями и навыками, чем мелкие инвесторы;

- диверсификация. Мелкие инвесторы не в состоянии снизить риск путём диверсификации из-за высоких затрат на проведение операций при небольшом количестве акций;

- снижение затрат. При управлении большим числом мелких инвестиций как одним крупным портфелем можно добиться экономии за счет масштаба операций, от чего инвестор может получить выгоду в виде низкой платы за управление;

- надежность. Коллективные инвесторы практически во всех странах являются объектом законодательства и регулирования, направленного на защиту интересов мелких инвесторов.

Таким образом, мобилизация средств посредством коллективного инвестирования предполагает реализацию комплекса мер государства. Приоритетными направлениями государственной политики в этой области являются: - стимулирование роста капитализации фондового рынка; расширение финансового инструментария; - активизация первичного размещения акций; - формирование правовой базы для секьюритизации финансовых активов и выпуска в обращение производных инструментов; - 
жесткая регламентация финансового рынка и деятельности всех его участников в целях защиты интересов частных вкладчиков. Все эти меры будут способствовать увеличению капитализации казахстанского фондового рынка, диверсификации инвестиционных вложений коллективных инвесторов, решению проблем, препятствующих развитию паевых инвестиционных фондов.

\section{Список литературы}

1. Макроэкономика: Учебное пособие / С.Г. Капканщиков; 2-е изд., перераб. и доп. Москва: КНОРУС, 2010. 390 с.

2. Рынок ценных бумаг: учебник для академического бакалавриата/Н.И. Берзон [и др.]; под общей редакцией Н.И. Берзона. - 4-е изд., перераб. и доп. Москва: Издательство Юрайт, 2019. - 443с.

3. Инвестиции: учебник для вузов / под ред. Л.И. Юзвович, С.А. Дегтярева,

Е.Г. Князевой. - Екатеринбург : Изд-во Урал. ун-та, 2016. - 543 с.

4. Агентство Республики Казахстан по регулированию и развитию финансового рынка. Обзор финансового сектора Республики Казахстан за декабрь 2020 года. Алматы.

5. Закон РК «Об инвестиционных и венчурных фондах РК» от 07.07.2004 года N 576. 


\section{УДОСКОНАЛЕННЯ ОБЛІКУ ВИТРАТ НА ПІДПРИЕМСТВАХ ОПТОВОЇ ТОРГІВЛІ}

\section{Шаровська Тамара Сергї̈вна,}

к.е.н., доцент,

Одеський національний економічний університет

Шерстюк Марія, студентка 51 групи 5 курсу ФМОIТ, Одеський національний економічний університет

Постановка проблеми у загальному вигляді. Сучасні економічні відносини потребують постійного вдосконалення та глибоких перетворень, зокрема перетворень у системі обліку. Сьогодні питання обліку витрат $\epsilon$ надзвичайно важливим як для всіх господарюючих суб'єктів, так і для держави в цілому. Формування достовірної та оперативної інформації про них є важливим та одночасно складним елементом системи організації обліку на підприємстві. Саме від цього буде залежати рівень управління ними, рентабельність виробництва, виявлення резервів зниження собівартості продукції, визначення цін на продукцію, а також прийняття необхідних управлінських рішень.

Аналіз досліджень і публікацій останніх років. Проблемам обліку витрат приділялося чимало уваги зарубіжними і вітчизняними науковцями. Найбільш фундаментальними і такими, що охоплюють різні аспекти цієї проблеми, є праці авторів: Дуляба H.I. (розглянуто класифікацію поточних витрат торговельного підприємства) [1], Реслер М. В. (розглянуто класифікацію витрат підприємств торгівлі в системі обліку та управління ними) [2] та ін.

Проблеми обліку та контролю витрат висвітлено в працях М. Т. Білухи, О. С. Бородкіна, А. М. Герасимовича, М. В. Кужельного, В. С. Ластовецького, В. Г. Лінника, Ю. Я. Литвина, С. В. Мниха, Л. В. Нападовської, І. І. Пилипенка, В. В. Сопка, Л. К. Сука, М. Г. Чумаченка, В. Г. Швеця, В. О. Шевчука та інших учених.

Виділення невирішених раніше частин загальної проблеми. За ринкових умов господарювання максимізація прибутку може досягатися лише при раціональному використанні ресурсів підприємства. А так як використання ресурсів нерозривно пов'язане 3 витратами, тому важливим завданням для мінімізації витрат і збільшенні прибутку підприємства є управління ними. На торгівельних підприємствах необхідно чітко визначити структуру витрат, відстежити їх динаміку, що дозволить розробити комплекс заходів, спрямованих на зменшення рівня витрат та, як наслідок, збільшення прибутку підприємства.

Тож, як свідчать проведені дослідження, розвиток і ефективність діяльності торгівельних підприємств неможливі без удосконалення системи управління витратами, адже витрати є основним фактором впливу на фінансовий результат.

Постановка завдання. Метою статті $є$ узагальнення видів витрат оптових торгівельних підприємств за різними класифікаційними ознаками та 
дослідження особливостей формування їх структури в сучасних умовах господарювання.

Виклад основного матеріалу дослідження. Торговельна діяльність в Україні на даний час є однією 3 найпоширеніших форм підприємництва. У статутних документах будь-якого підприємства в якості виду підприємницької діяльності найчастіше вказується торгівля. Відповідно до розділу 1 ст. 263 господарського кодексу України господарсько-торговельною є діяльність, що здійснюється суб’єктами господарювання у сфері товарного обороту, спрямована на реалізацію продукції виробничо-технічного призначення i виробів народного споживання, а також допоміжна діяльність, яка забезпечує їх реалізацію шляхом надання відповідних послуг [3]. У п. 3 ст. 263 цього кодексу наведено форми господарсько-торговельної діяльності, які можуть здійснювати суб'єкти господарювання:

- матеріально-технічне постачання і збут;

- енергопостачання;

- заготівля;

- оптова торгівля;

- роздрібна торгівля і громадське харчування;

- продаж і передача в оренду засобів виробництва;

- комерційне посередництво у здійсненні торговельної діяльності;

- інша допоміжна діяльність по забезпеченню реалізації товарів (послуг) у сфері обігу [3].

Торгівля $€$ однією 3 провідних галузей економічної діяльності та найрозвиненішою формою підприємництва. Торгівля - це вид економічної діяльності у сфері товарообігу і просування товарів від виробника до споживача у формі купівлі-продажу та надання пов'язаних із цим послуг.

Торговельна діяльність - ініціативна, систематична, виконувана на власний ризик для одержання прибутку діяльність юридичних i фізичних осіб щодо купівлі та продажу товарів кінцевим споживачам або посередницькі операції, або діяльність із надавання агентських, представницьких, комісійних та інших послуг у просуванні товарів від виробника до споживача [4].

Основним завданням бухгалтерського обліку на підприємствах оптової торгівлі $\epsilon$ контроль за виконанням договірних постачань товарів постачальниками, продажем товарів покупцям, контроль за станом товарних запасів. як правило, між продавцем та покупцем укладається договір купівліпродажу. Згідно зі ст. 655 цивільного кодексу україни за даним договором одна сторона (продавець) передає або зобов'язується передати майно (товар) у власність іншій стороні (покупцю), а покупець приймає або зобов'язується прийняти майно (товар) і сплатити за нього відповідну грошову суму [4].

Витрати на торгівельних підприємствах доцільно розглядати 3 точки зору П(С)БО 16 «Витрати», в якому зазначається, що витратами звітного періоду визнаються або зменшення активів, або збільшення зобов'язань, що призводить до зменшення власного капіталу підприємства (за винятком зменшення капіталу внаслідок його вилучення або розподілу власниками), за умови, що ці витрати можуть бути достовірно оцінені [5]. 
Витрати торгівельних підприємств законодавчо регламентуються «Методичними рекомендаціями 3 формування складу витрат та порядку їх планування у торговельній діяльності». Відповідно до них до складу витрат торговельної діяльності належать витрати підприємств, що здійснюють таку діяльність, які виникають у процесі руху товарів, а також витрати закладів ресторанного господарства, що пов'язані з випуском і реалізацією продукції власного виробництва. Саме у цьому документі зазначено використання терміна «поточні» стосовно витрат торгівельного підприємства. Поточні витрати підприємства торгівлі - це грошове відбиття витрат живої та уречевленої праці на здійснення поточної торговельно-виробничої діяльності підприємства, що за натурально-речовим складом становлять спожиту частину матеріальних, нематеріальних трудових та фінансових ресурсів [6].

До складу поточних витрат підприємства торгівлі входять витрати обігу представлені в грошовій формі витрати підприємства на здійснення процесу реалізації товарів, які складають за своєю суттю собівартість послуг з доведення товарів від виробника до споживача та пов'язаних із зміною форм вартості.

У плануванні та обліку поточні витрати торгівельної діяльності класифікують за видами діяльності, еокономічними елементами та статтями витрат.

В управлінні поточними витратами торгівельної діяльності, крім зазначених класифікаційних ознак, можна застосовувати додаткові ознаки класифікації - за ступенем реагування на зміну обсягів діяльності, за періодами, за центрами відповідальності чи місцем виникнення, за ступенем однорідності, за можливістю контролю в конкретному структурному підрозділі, за принципами організації управління [6].

Поточні витрати підприємств торгівлі за видами діяльності класифікують за такими групами:

- витрати операційної діяльності;

- витрати фінансової діяльності;

- інші витрати звичайної діяльності;

- надзвичайні витрати.

Витрати операційної діяльності поділяють на:

- витрати, які включають до собівартості реалізованих товарів та/або продукції власного виробництва;

- адміністративні витрати;

- витрати на збут;

- інші операційні витрати.

Для обліку торговельних витрат Планом рахунків бухгалтерського обліку призначено клас 9 «Витрати діяльності», який включає рахунки першого порядку 90 «Собівартість» реалізації», 91 «Загальновиробничі витрати», 92 «Адміністративні витрати», 93 «Витрати на збут», 94 «Інші витрати операційної діяльності».

Собівартість реалізованих товарів — це первинна вартість товарів, що вибули. Оцінку товарів при їх продажу та іншому вибутті здійснюють за одним 3 методів, наведених у П(С)БО 9 «Запаси»: 
- ідентифікованої собівартості;

- середньозваженої собівартості;

- собівартості перших за часом надходження товарів (ФІФО);

- нормативних затрат;

- ціни продажу.

Незалежно від прийнятого методу оцінки, про який зазначено у обліковій політиці підприємства, списання реалізованих товарів за собівартістю на підприємствах оптової торгівлі відображають записами:

Дебет субрахунка 902 «Собівартість реалізованих товарів» Кредит субрахунка 281 « Товари на складі».

Кредитується субрахунок 902 у кінці місяця (звітного періоду) на суму списаної собівартості реалізованих товарів за дебетом субрахунка 791 «Результат основної діяльності». Таким чином, сальдо на субрахунку 902 відсутнє.

Придбання товарів може бути пов'язано з додатковими витратами. Оскільки деякі витрати, що пов'язані з придбанням товарів, можна визначити тільки після закінчення звітного періоду, а також через великий асортимент товарів складно правильно розподілити транспортно-заготівельні витрати на одиницю товарів. Тому, відповідно до П(С)БО 9 «Запаси», підприємства торгівлі до собівартості одиниці товару включають транспортно-заготівельні витрати чи на момент придбання товару, чи у кінці звітного періоду при визначенні собівартості реалізованих товарів.

Для обліку транспортно-заготівельних витрат (ТЗВ) до Плану бухгалтерських рахунків введено субрахунок 289 «ТЗВ».

За дебетом субрахунків 289 накопичуються ТЗВ (без ПДВ) та 641 «Розрахунки за податками» на суму ПДВ, чи з ПДВ, якщо підприємство не $\epsilon$ платником ПДВ, та кредиту рахунків 63 «Розрахунки 3 постачальниками та підрядчиками», 685 «Розрахунки 3 іншими кредиторами». У кінці місяця, за результатами розрахунка, ТЗВ, які віднесені до реалізованих товарів, списують за кредитом субрахунка 289 у дебет 902.

Таким чином, собівартість реалізованого товару є достовірною. Сальдо на кінець місяця за субрахунком 289 зазначає ТЗВ на залишок товару, які будуть враховані при обчислюванні ТЗВ на реалізовані товари у послідуючому звітному місяці [4].

До витрат операційної діяльності торгових підприємств належать витрати 3 управління діяльністю (адміністративні витрати), зі зберігання та реалізації товарів (витрати на збут), інші витрати операційної діяльності, які не включаються до собівартості товарів, а списуються на фінансові результати у дебет рахунку 791 «Результат операційної діяльності».

До складу адміністративних витрат підприємств комерційної діяльності належать витрати, що мають загальногосподарський характер і пов'язані із управлінням та обслуговуванням торгівельного підприємства.

Облік цих витрат ведуть за такими статтями:

- витрати на оплату праці адміністративно-управлінського персоналу;

- відрахування на соціальні заходи; 
- витрати на оренду основних засобів, інших необоротних матеріальних активів, нематеріальних активів, що забезпечують адміністративні потреби;

- витрати на утримання основних засобів, інших необоротних матеріальних активів, малоцінних i швидкозношуваних предметів, що забезпечують адміністративні потреби;

- амортизація основних засобів, інших необоротних матеріальних активів i нематеріальних активів, що забезпечують адміністративні потреби;

- витрати на страхування майна;

- податки, збори й інші передбачені чинним законодавством обов'язкові платежі; загальні корпоративні витрати;

- інші адміністративні витрати

До складу витрат на збут у торговельних організаціях належать: витрати обігу, за винятком адміністративних витрат, інших операційних і фінансових витрат.

Зокрема, до витрат на збут належать:

- витрати на оплату праці персоналу, що забезпечує збут товарів (продукції);

- відрахування на соціальні заходи; витрати на оренду основних засобів, інших необоротних матеріальних активів i нематеріальних активів, що забезпечують збут товарів (продукціі);

- витрати на утримання основних засобів, інших необоротних матеріальних активів, малоцінних швидкозношуваних предметів, що забезпечують збут товарів (продукціі);

- амортизація основних засобів, інших необоротних матеріальних активів i нематеріальних активів, що забезпечують збут товарів (продукції);

- витрати на зберігання, підсортування, оброблення, пакування й передпродажну підготовку товарів (продукції);

- витрати на транспортування;

- витрати на маркетинг;

- витрати на тару;

- податки, збори та інші передбачені законодавством обов'язкові платежі;

- інші витрати на збут.

До інших операційних витрат належать:

- витрати на дослідження й розроблення; собівартість реалізованої іноземної валюти; собівартість реалізованих виробничих запасів;

- сумнівні та безнадійні борги;

- втрати від операційної курсової різниці;

- втрати від знецінення запасів;

- нестачі і втрати від псування цінностей;

- визнані штрафи, пені, неустойки;

- інші витрати операційної діяльності .

Дослідження доводять, що торговельним підприємствам часто недостатньо інформації про витрати у розрізі встановленої номенклатури статей. У цьому зв'язку 3 метою виділення витрат за елементами у системі рахунків бухгалтерського обліку в торгівельних підприємствах пропонуємо застосовувати інтегровану методику фінансового та управлінського обліку. 
Планом рахунків бухгалтерського обліку передбачено «вмонтування» рахунків внутрішньогосподарського (управлінського) обліку до системи рахунків фінансового обліку підприємств. Вважаємо, що для цілей організації управлінського обліку торговельних витрат до рахунків фінансового обліку витрат, передбачених Планом рахунків, потрібно відкрити рахунки третього і четвертого порядків - субрахунки та аналітичні рахунки внутрішньогосподарського (управлінського) обліку.

Висновки і перспективи подальших розробок. В результаті проведеного дослідження розглянуто основні підходи до визначення витрат, розглянуто їх класифікацію, принципи організації обліку витрат, виділено основні проблемні питання обліку витрат на оптових підприємствах. Таким чином, правильний облік витрат, своєчасний контроль за їх формуванням, оперативний аналіз мають велике значення для ефективного управління витратами підприємства. Наведені рекомендації сприятимуть більш повному розкриттю даних про витрати торговельних підприємств, що, в свою чергу, дасть змогу поліпшити інформаційне забезпечення процесу управління ними у торгівельних підприємствах та буде сприяти підвищенню ефективності їх діяльності.

\section{Список літератури:}

1. Дуляба Н.І. Класифікація поточних витрат торговельного підприємства. Економічна теорія. 2018. URL:http://chteiknteu.cv.ua/herald/content/download/archive/2018/v1/NV-2018-V1_1.pdf (дата звернення: 03.11.2020).

2. Реслер М. В. Класифікація витрат підприємств торгівлі в системі обліку та управління ними. Вісник Львівського торговельно-економічного університету. Економічні науки. 2019. Вип. 57. С. 100-103. URL: http://nbuv.gov.ua/UJRN/Vlca_ekon_2019_57_17 (дата звернення: 03.11.2020).

3. Господарський кодекс України від 16.01.2003 p. № 436-IV. URL: https://zakon.rada.gov.ua/laws/show/436-15\#Tеxt (дата звернення: 05.11.2020).

4. Колумбет О.П., Малиневська Д.П. Особливості руху товарів на підприємствах оптової торгівлі. Журнал «Молодий вчений». 2018. № 1 (53). URL: http://molodyvcheny.in.ua/files/journal/2018/1/210.pdf (дата звернення: 03.11.2020).

5. Положення (стандарт) бухгалтерського обліку № 16 «Витрати», затверджено наказом Міністерства фінансів України від 31.12.99 № 318. URL: https://zakon.rada.gov.ua/laws/show/z0027-00\#Text (дата звернення: 05.11.2020).

6. Методичні рекомендації з формування складу витрат та порядку їх планування у торговельній діяльності (наказ Міністерства економіки та 3 питань європейської інтеграції України № 145 від 22.05 .2002 р.). URL:https://zakon.rada.gov.ua/rada/show/v0145569-02\#Text

(дата звернення: 05.11.2020).

7. Наказ МФУ від 14.06 .2000 URL:https://zakon.rada.gov.ua/laws/show/z0359-00\#Text 05.11.2020).

p. № 131 . (дата звернення: 


\title{
ОПТИМІЗАЦІЯ ПОБУДОВИ РАДІОЛОКАЦІЙНОГО ПОЛЯ ІНФОРМАЦІЙНОЇ СИСТЕМИ МОНІТОРИНГУ НАВКОЛИШНЬОГО СЕРЕДОВИЩА
}

\author{
Глушков Андрій Володимирович \\ Старший викладач кафедри \\ Одеський державний екологічний університет
}

Шанюк Олег Віталійович

Старший викладач кафедри Одеський державний екологічний університет

Стан атмосфери істотно визначає ефективність функціонування різних галузей господарства - транспорту, сільського, лісового та водного 13 господарства, а також різних міських структур.

Інформацію про стан атмосфери надають, в ряду існуючих технічних засобів, i радіолокаційні станції (РЛС). Більш ніж шістдесятирічний досвід їх застосування для спостереження за хмарами і опадами дозволив сформулювати досить чіткі вимоги до РЛС метеорологічного призначення. Ці вимоги залежать як від розв'язуваних метеорологічними РЛС (МРЛС) завдань, так і від метеорологічних умов поширення радіохвиль в даному фізико-географічному районі. Однак, сучасні кліматичні зміни, що торкнулися, в тому числі, і території України, а також удосконалення технічних засобів наземного зондування атмосфери, висувають нові вимоги до гідрометеорологічної інформації, одержуваної від МРЛС. Метою дослідження є уточнення вимог до МРЛС 3 урахуванням мінливих кліматичних умов i необхідності побудови радіолокаційної системи, що утворює єдине радіолокаційне поле над всією територією країни і прилеглими до неї районами.

Таким чином, цілі наземного дистанційного радіолокаційного зондування атмосфери можна сформулювати наступним чином:

1) контроль стану атмосфери, що включає в себе щоденний моніторинг, своєчасне виявлення небезпечних явищ;

2) здійснення прогнозів погоди різної завчасності;

3) дослідження клімату певної території та прогноз його можливих змін;

4) науково-дослідні завдання.

В роботі розглядаються основи методики побудови радіолокаційної системи моніторингу навколишнього середовища.

Для оптимізації за різними критеріями побудови названої системи потрібний програмний засіб, який дозволяє з невеликими витратами часу, перебираючи різні варіанти побудови, обрати оптимальний варіант. 
Такий програмний засіб був розроблений попередньою групою магістрів, та використовувався мною для виконання робіт по розташуванню радарів та оптимізації радіолокаційного покриття.

Для побудови радіолокаційного поля потрібно було керуватись наступними критеріями: радіус огляду радару, мінімальна кількість радарів, мінімальна відстань да метеорологічних станцій та максимальна до населених пунктів, мінімальна вартість побудови радіолокаційного поля, відсутність “мертвих" зон.

Мертві зони утворюються при розстановці радарів таким чином, що при зіткненні їх полів з'являється дірка, але бувають проблеми освічені самим рельєфом наприклад височини.

При дослідженні радіолокаційних полів необхідно брати до уваги санітарну зону, а саме високе випромінювання, яке може вплинути на населені пункти, розташовані недалеко від місця установки радара. Цього можна уникнути шляхом конфігурації розстановки РЛС або зменшення їх потужності. Конфігурується оптимальна розстановка на місцевості.

Для оптимальної побудови радіолокаційної системи моніторингу навколишнього середовища необхідно розглянути декілька варіантів ii 14 побудови. Кожен із варіантів оптимізований по одному, або декільком критеріям, задовольняючих замовника. Обчислення та побудова радіолокаційної системи - це злагоджена вичислювально-графічна задача, яка потребує багатократного рішення при різних початкових даних та критеріях.

Саме цьому для проведення цієї аналітичної роботи необхідний інструмент, дозволяючи виконувати такі графічно-вичислювальні роботи. Подібний інструмент був розроблений на кафедрі АСМНС в рамках держбюджетної НДР 0113U000164-c.

Він представляє собою програмний комплекс, який дозволяє моделювати радіолокаційні поля для дослідження їх енергетики на реальному рельєфі, реальної місцевості (В якості платформи для розробки був узятий фреймворк NASA World Wind.).

Саме це програмне забезпечення має ряд необхідних характеристик i можливостей, необхідних для виконання мого завдання, таких як: робота 3 рельєфом місцевості в 3D, побудова графіків як в 2-ух, так і в 3-ьох координатній системах, використання при побудові графіків кольорового градієнту, накладення рельєфу на карту місцевості в 3D, можливість роботи як в onlineрежимі, так і в ofline, та багато ін. В цій роботі також були розглянуті основні характеристики і параметри цього програмного комплексу.

Радари заданої потужності розташовано в межах метеорологічних станцій на території України таким чином, щоб в зону покриття входила вся територія країни. На даний момент мною використано 5 типів радарів (радіусом дії 300 км, 250 км,150 км, 100 км та 70 км). 


\section{ПЕРЕЛІК ПОСИЛАНЬ}

1. Принципы построения автоматизированных систем метеорологического обеспечения авиации: Монография ГГО им. А.И. Воейкова ; под ред. Г.Г. Щукина. Лениград : Гидрометеоиздат, 1991. 373 с.

2. Базлова Т.А., Бочарников Н.В., Брылев Г.Б. [и др.] Метеорологические автоматизированные радиолокационные сети : монография ИРАМ ; под редакцией Г.Б. Брылева. С.-Петербург : Гидрометиздат, 2002. 332 с.

3. Perelygin B.V. Implementation of systematic approach in the creation of radar systems of meteorological monitoring // Telecommunications and radio engineering. 2018. Vol. 77. № 3. P. 199-209. Doi: 10.1615/TelecomRadEng.v77.i3.20.

4. Руководство по производству наблюдений и применению информации с неавтоматизированных радиолокаторов МРЛ-1, МРЛ-2 и МРЛ-5: Руководящий документ РД 52.04.320-91. С.-Петербург : Гидрометеоиздат, 1993. 358 с. 


\title{
FORMATION AND DEVELOPMENT OF THE THEORY OF DYNAMIC SYSTEMS (1930-1960s)
}

\author{
Kilochytska Tetyana \\ Ph.D. in Historical Sciences, Associate Professor, \\ Associate Professor of the Department of General Technical \\ Disciplines and Drawing, \\ T.H. Shevchenko National University «Chernihiv Colehium» \\ (Chernihiv, Ukraine)
}

Methods of the theory of dynamical systems are used in many modern scientific researches. The development of this theory has led to the creation of other scientific branches, one of which is nonlinear dynamics. Nonlinear dynamics includes the theory of stability, the theory of dynamic chaos, ergodic theory, and the theory of integrated systems. Therefore, it is important to study the origin and development of the theory of dynamical systems. The main task of the theory of dynamical systems is to study curves described by differential equations. This includes the division of the phase space into trajectories and studying of the boundary behavior of such trajectories: search and classification of equilibrium positions, detachment of attractors. The most important concepts of the theory of dynamic systems are stability (the ability of the system to stay at equilibrium or at a given variety for as long as desired) and roughness (preservation of properties against small changes in the structure of a dynamic system).

A. Poincaré in his works «On curves defined by differential equations» (1885) and «New methods of celestial mechanics» (1892-1899) proposed to determine the nature of motion by the type of the right part of the differential equation, without integrating it, and to find curves that correspond to periodic solutions, from the set of integral curves [1]. He developed a method for determining these curves - a geometric method for qualitative description of motion in phase space. Influenced by the ideas of A. Poincaré, J. Birkhoff introduced the concept of a dynamic system, which became his main object of study [2]. Dynamic system is a mechanical system with a finite number of degrees of freedom (later, a system whose evolution on the basis of a dynamic law is unambiguously determined by its initial conditions). Birkhoff put forward a global program to study dynamical systems (Poincaré-Birkhoff program, 1927): to give a general classification of all types of dynamical system's movements. He proved the theorem, which was called «Poincaré's last theorem» and published in 1927: periodic motions can serve as a basis for studying all motions in the three-body problem [3]. In 1930, O.O. Andronov and O.A. Witt revealed a correspondence between oscillations in systems with many degrees of freedom and Birkhoff's recurrent motions. The results of applying the apparatus of point mappings to nonlinear problems were included in the first edition of «Theory of Oscillations» [4]. L.I. Mandelstam noted that in the work of Andronov «... we have a mathematical apparatus which is really adequate to our nonlinear problems and does not contain "linear references", 
even if not sufficiently developed. Based on this apparatus, it will be possible to create new concepts specific to nonlinear systems and to develop new control points of view that will allow nonlinearly thinking» $[5,6]$.

On the basis of the fundamental concepts of A. Poincare - the concepts of characteristics, semi-characteristics, special point - O.O. Andronov introduced new definitions: those of trajectory, semi-trajectory, state of equilibrium for the system. He pointed out that the concept of a separate characteristic given by A. Poincaré is not completely defined, because the concept of a curve given by a differential equation is not clarified $[6,371]$. In order to clarify this concept, the notion of trajectory was introduced instead of the notion of characteristic, and its definition was given.

In 1937, O.O. Andronov and L.S. Pontryagin formulated in their work «Rough Systems» the requirement of stability according to Lyapunov [7]. Andronov wrote that motions that are real oscillations must be stable with respect to small changes in their initial conditions. The works of O.O. Andronov and E.N. Leontovich contain a general theory of dependence on the parameter of the phase plane partitioning into trajectories [8]. In particular, they considered main bifurcations of the equilibrium state and clarified cases of stability disturbance, the origin of the boundary cycle from the equilibrium state of the complex focus type, from the double boundary cycle, from the saddle separatrix, from the separatrix of a complex singular point of the saddle-node type structurally stable systems [9]. An important topological invariant that influenced the further development of the theory of dynamical systems is the concept of roughness (structural stability), introduced by O.O. Andronov and L.S. Potyagin in 1937. Rough systems are a class of dynamical systems where the topological structure of phase trajectories does not change with small changes in differential equations. Moreover, the systems studied do not have to be dynamic, and the classification, to be topological. Qualitative behavior of a system is changed by small changes in the model. Closely related to the roughness is the concept of bifurcations, whose theory was developed in the school of Andronov. In 1938, the concept of a non-rough dynamical system was introduced, where small changes in the parameters lead to a change in the structure of the division of its phase plane into trajectories, and also the concept of degrees of coarseness [8]. There appears the problem of research of non-rough systems and their classification.

Based on the introduced concepts of rough and non-rough systems, Andronov expanded Poincaré's problem: not only to identify the possible nature and behavior of a particular trajectory, but also to identify the properties of partitioning the phase space of a dynamical system into trajectories (the study program of Poincaré-Birkhoff dynamical systems was partially implemented only for the case of Hamiltonian systems with two degrees of freedom). The results of Poincaré and Birkhoff give an idea of the nature of motion, but they can not be used to investigate the differential equation. Andronov was interested not only in statistical investigation of the dynamic system structure of the phase space, but also in considering changes in this structure of partitioning when changing the system itself, i.e. when changing the functions in right parts of equations which describe the motion of that system (the research program of Andronov and Pontryagin). Implementation of the program represents a quantitative and qualitative study of a system, i.e. finding all possible states of equilibrium and 
periodic motions, studying their stability and dependence on system parameters, finding all possible bifurcations and determining in space all parameters of areas with different topological structures, determining quantitative characteristics of the system. The parameter space is divided into areas corresponding to different partitions of the phase space. The boundaries of those regions correspond to the bifurcation values of the parameters, when their small change leads to a change in the topological structure of the phase space partition.

S. Smale singled out an important class of unstable dynamical systems. In 1960, he considered dynamic systems that are rough regardless of their dimension (MorseSmale system) [10]. In 1961, Smale spoke at the International Symposium on Nonlinear Oscillations in Kyiv and proposed a mathematical model that demonstrates chaotic behavior in a two-dimensional representation (Smale's horseshoe) - that was the first example of a rough system with complex dynamics. He also hypothesized the roughness of geodetic flows on compact manifolds of negative curvature and hyperbolic automorphisms of a torus [11].

In 1966, Smale established the existence of a region of phase space where nonrough systems form a dense everywhere set (atypicality of Morse-Smale systems with dimension $n \geq 3$ ) and showed that multidimensional analogues of two-dimensional systems with simple behavior are nowhere dense (1966) [12]. This marked the beginning of a new stage of qualitative integration.

That started the study of general, typical characteristics of a whole class of dynamical systems, and the concept of typicality becomes of paramount importance.

In the multidimensional case, dynamic systems with complex behavior are typical. For multidimensional systems homoclinical structures are typical, and for twodimensional ones, equilibrium states and periodic motions. The question arises about the possibility of transition from Morse-Smale systems to systems with a homoclinic structure. In this case, the changes concern the entire phase space, not just a single equilibrium position or periodic trajectory. Andronov's school considered such global bifurcations.

In the 1960s, it was considered impossible to explain the main properties of dynamical systems based on hyperbolicity. It was assumed that multidimensional dynamical systems are characterized by simple behavior, as in the two-dimensional case. At that time, hyperbolic systems were studied, in which hyperbolicity is «complete» and «uniform» in any direction of shift. This led to Smile's introduction of the concept of hyperbolic sets, which should give an idea of the global structure of the whole system.

More complex than Morse-Smale systems are systems with the axiom «A» (that have the properties of exponential instability of trajectories), which was formulated for them by Smale in 1967.

The rapid development of the theory of dynamical systems took place in 1960 1970s.

\section{References:}

1. Poincaré, A.( 1947). On curves determined by differential equations. Moscow. Gostekhizdat. 392.

2. Birkhoff, G.D. (1927). Dynamical Systems. Providence, Rhod Island: AMS. 295. 
3. Birkhoff, G.D. (1940). Dynamical Systems. Moscow, Gostekhizdat.320.

4. Andronov, A.A., Khaikin, S.E. (1937). Theory of oscillations. MoscowLeningrad. ONTI. 519.

5. Andronov, A.A., Witt, A.A., Khaikin, S.E. (1959). Oscillation theory. Moscow, Fizmatgiz.915.

6. Poincaré A. (1947). On curves determined by differential equations. Moscow. Gostekhizdat. 371-390.

7. Andronov, A.A., Pontryagin, L.S. (1937). Rough systems. Dokl. Academy of Sciences of the USSR. T. 14, №5. 247-252.

8. Andronov, A.A., Leontovich, E.N. (1938). On the theory of changes in the qualitative structure of dividing a plane into trajectories. Dokl. Academy of Sciences of the USSR. T. 21. № 9. 247-252.

9. Andronov, A.A., Leontovich, E.N. (1939). Some cases of dependence of limit cycles on parameters. Scientific notes of the Gorky University. № 6. 3-32.

10. Smale, S. (1960). Morse inequalities for a dynamical system. Bull. AMS. V. 66. P. 43-49.

11. Smale, S. (1963). A structurally stable differential homomorphysm with an infinite number of periodic points. Proceedings of the International Symposium on Nonlinear Oscillations. Kiev, Academy of Sciences of the Ukrainian SSR. 365-366.

12. Smale,S. (1966). Structurally stable systems are not dense. Am. J. Math. V. 73. 747-817. 


\title{
НЕТОЛЕРАНТНА ЛЕКСИКА В ЗАСОБАХ МАСОВОЇ КОМУНІКАЦІї
}

\author{
Ус Тетяна Іванівна, \\ кандидат педагогічних наук \\ Фаховий коледж «Універсум» \\ Київського університету імені Бориса Грінченка \\ Малюта Вікторія Олександрівна, \\ студентка, \\ Фаховий коледж «Універсум» \\ Київського університету імені Бориса Грінченка
}

Нині існує актуальна проблема використання нейтральної лексики у сучасних медійних і рекламних засобах масової комунікації. Не створений чіткий перелік слів, що $є$ нейтральними стосовно вразливих груп реципієнтів, а саме представників расових, етнічних, гендерних, сексуальних меншин та людей із вадами здоров'я.

Хоча «Загальна декларація прав людини» й забороняє прояв всіх форм расової й іншої дискримінації, сучасні ЗМК використовують неетичну лексику у медіа, що укорінює гендерні, расові та інші стереотипи, негативно впливаючи на вразливі групи населення [2].

До теми толерантності у комунікативних виданнях у своїх роботах зверталися такі дослідники: 3. Бауман, Н. Бердясв, І. Бубіс, Р. Валітова, Л. Вітгенштейн, А. Вірлахер, 3. Дубинець, А. Капто, П. Кропоткін, Н. Купіна, Е. Ларіна, О.А. Михайлова, М. Розенбах, П. Сорокін, І. Стернін, Е. Суміна, М. Хомяков, Г. Яворська.

Метою нашого дослідження $\epsilon$ визначити альтернативні нормативні відповідники нетолерантній лексиці у сучасних засобах масової комунікації. Для цього варто проаналізувати поняття «нормативна лексика» та сформулювати список вразливих груп реципієнтів; проаналізувати сучасні комунікативні видання та знайти в них термінологію, яка найчастіше вживається стосовно вразливих груп реципієнтів та віднайти універсальні джерела нормативної лексики для сучасних комунікативних видань.

Поняття «нормативна лексика» не має чіткого пояснення та не зазначене у словниках, зате є чітко сформульоване визначення «ненормативної лексики».

Ненормативна лексика (мат, нецензурна лексика, обсценна (непристойна) лексика, лихослів'я) - до цього визначення входять такі поняття, як блюзнірство, прокльони і лайка. Така мова перебуває поза нормальним стилем спілкування. 
3 цього визначення можна зробити висновки про те, що нормативна лексика - це унормована лексика, яка може вживатися у будь яких видах мовлення і яка $є$ нейтральною стосовно будь-якого мовця.

Питання «унормованості» постає гостро, адже лише зараз українське суспільство почало робити акцент на нормативність звертань до вразливих прошарків суспільства у ЗМI, а значить, новий правопис ще не регламентував найбільш нейтральну лексику стосовно них.

Можна чітко виділити такі категорії та такі найрозповсюдженіші ненормативні звертання (табл. 1.):

Таблиця 1. Найрозповсюдженіші ненормативні звертання до вразливих верств населення

\begin{tabular}{|c|l|}
\hline Уразлива група & \multicolumn{1}{|c|}{ Найрозповсюдженіші ненормативні } \\
звертання
\end{tabular}

Чим менш вивченою та актуальною у ЗМК є проблема ненормативної лексики, тим більш розповсюдженими $\epsilon$ такі звертання. Проблемою $\epsilon$ не лише використання, а й розповсюдженість таких звертань у засобах масової комунікації, що сприяє популяризації їх у лексиконі звичайного мовця. Прикладом $є$ слово «негр», яке вже давно вважається неприйнятним для ЗМК та ділової лексики, але часто використовується у побутовому спілкуванні та літературі. Прикладом можна вважати книгу Ірени Карпи «3 роси, 3 води і 3 калабані», де навіть у описі книги $є$ слова «Мемуари зірки, за яку жоден літературний негр не взявся б писати автобіографію!».

Ненормативна лексика стосовно етнічних та расових меншин $є$ найменш вживаною, так як тема расизму є ангажованою через криміногенність настроїв на території України.

Частіше за все нетолерантні вислови стосовно цієї групи населення можна почути на ТБ або прочитати у пресі. Наприклад, журналіст парламентської газети «Голос України» розгнівав мережу расистськими висловлюваннями у статті, що має заголовок «Сврей - клоун-президент та «Беленюк - негр» [1]. У тернопільській інтернет-газеті «Про все» вийшла стаття із заголовком «Негр 3 Конго напав у Тернополі на поліцейського» [8]. Складається враження, що в регіональних ЗМК основною задачею $є$ побудова вигідних настроїв у окремої групи реципієнтів. 
Активність ксенофобських рухів за часів незалежної України можна датувати 2001 роком, коли у Вінниці забили насмерть руандійця. Відтоді рівень толерантності суспільства до національних та етнічних меншин знижувався щороку на 3,5 разів [5]. На думку деяких дослідників, станом на 2003 рік більш ніш половина населення мала ксенофобні настрої [10].

Більш криміногенною ситуація стала після 2005 року, коли почалися активні рухи організацій скінхедів, що пропагували ідеї звільнення України від нац-, етнічних меншин, проводячи марші, закриті збори та концерти гуртів із музикою неонациського спрямування.

Також негативний вплив на толерантність суспільства мають і події «Революції Гідності», які збільшили чисельність праворадикальних організацій, що також в більшості випадків вважають «звільнення України» частиною свого завдання.

Хоча Закон України «про засади запобігання та протидії дискримінації в Україні» існує з 2013 року, у ньому чітко не прописано, які слова, вирази $\epsilon$ дискримінаційними для вразливих верств населення [3].

Нормативною альтернативою ксенофобним назвам, на нашу думку, можуть стати офіційно регламентовані відповідники, укладені історично (табл. 2):

Таблиця 2. Нормативні відповідники до ксенофобних звертань

\begin{tabular}{|c|c|}
\hline Ксенофобні звертання & Нормативні відповідники \\
\hline жиди & євреї \\
\hline москалі & росіяни \\
\hline чорні, негри & афроамериканці \\
хохли & українці \\
\hline цигани & роми \\
\hline
\end{tabular}

На цей час процес регламентування антидискримінаційної лексики лише розпочато. Так, МОН України розпочато у 2018 році перевірку шкільної літератури на наявність ксенофобної лексики, що може дати поштовх до створення чіткого списку назв [6].

Прикладів ненормативних висловів на тему сексуальної орієнтації і гендерної ідентичності, на нашу думку, найбільше у сучасному медіапросторі. Якщо расова дискримінація частіше за все існує через обмеженість знань людей у деяких сферах, то в цьому випадку ненормативні вислови використовуються навмисне для створення потрібних настроїв у соціумі.

Прикладом вживання негативно забарвленої лексики у сучасних виданнях $\epsilon$ стаття на новинному порталі «Obozrevatel» 3 таким заголовком: «Нетрадиційна сексуальна орієнтація вашої дитини» [9]. Формулювання «Нетрадиційна сексуальна орієнтація» є некоректним, бо поняття «традиційності» є розмитим та некоректним. Також у самому тексті статті присутні такі слова: «Але що ж робити, якщо дитина не така як усі в сексуальному плані?», які також $\epsilon$ некоректними стосовно гомосексуалів, бо акцентують увагу на стереотипі про 
те, що подібні стосунки існують лише у сексі. Гомо-, бісексуальність $є$ не лише сексуальним потягом, а й романтичними відносинами між людьми.

Можна виділити дві основні причини такого вживання ненормативної лексики у публікаціях про ЛГБТ+ людей:

1) необізнаність;

2) актуальність гомофобії в Україні.

3) Історія ставлення українського суспільства до ЛГБТ+ людей доволі неоднозначна.

Канонічна православна церква вважала і вважає одностатеві контакти гріхом, а у влади, що панувала на теренах України, не прослідковується чіткої позиції.

Перший антигомосексуальний закон ввів Петро I, взявши за основу німецький воєнний устав. Глава 3 , стаття 5 «Московського військового статуту» проголосила заборону зв'язків військових однієї статі [12].

1835 року на мешканців всієї Російської імперії поширив заборону Микола I у главі 4 розділі 9 «Зведення законів Російської імперії» [13]. Закони існували аж до Жовтневої революції, після якої переслідування припинилися, але не надовго.

Кримінальна відповідальність за «мужеложество» з'явилася в Радянському Союзі в сталінські часи - 17 грудня 1933 року опублікована Постанова ВЦВК, що стала законом 7 березня 1934 року [12].

За правління Л. Брежнєва почалися перші протести проти закону, але лише через два тижні після розвалу СРСР Горбачов підписав відміну кримінальної відповідальності [5].

Після цього почалася відкрита кампанія зі зміни ставлення людей до ЛГБТ + спільноти, у якій брали участь газети, журнали, та відбулися різноманітні акції щодо підтримки представників ЛГБТ+ [11].

Проте все ще $\epsilon$ нагальною проблема регульованості інформації, яку можливо отримати про ЛГБТ + спільноту. Особливо це актуально для підлітків, що лише проходять етап прийняття себе, своєї сексуальної орієнтації та гендерної ідентичності.

Як зазначалося вище, чіткого й регламентованого словника нормативної лексики стосовно ЛГБТ+ людей не укладено. Незважаючи на те, що у деяких сучасних виданнях і зазначають тлумачення слова «гомосексуалізм» [14], чіткого трактування навіть таких базових слів як «гей» чи «лесбійка» не існує.

Також немає чіткого поняття, як слід писати абревіатуру спільноти. Американські журналісти та ЛГБТ + - активісти долучають «К+» до абревіатури для позначення «queer personas» (квір персона - загальний термін на позначення ЛГБТК+, тобто людей, що не є гетеросексуальними або цисгендерними) LGBTQ/ЛГБТК+, але в офіційному правописі, прийнятому 2019 року, не регламентовано написання цієї абревіатури.

Єдиним альтернативним і незастарілим варіантом пошуку нормативних альтернатив $\epsilon$ використання робіт ЛГБТ+-активістів та дослідників цієї теми. Однією $з$ найповніших робіт є, на нашу думку, проект «Як писати про ЛГБТ. 
Курс для журналіста» громадської організації «Інсайт» за підтримки Article 19 [17].

Незважаючи на те, що Закон України «про внесення змін до деяких законодавчих актів України щодо застосування терміна «особа з інвалідністю» та похідних від нього» регламентував чітке формулювання звертання, ЗМК все ще продовжують використовувати слова «інвалід», «людина 3 особливими потребами» або «колясочник» у своїх статтях [4].

Так, на інтернет-порталі «Zik» опубліковано статтю, що має такий заголовок: «У Новояворівську відбувся фестиваль для людей з особливими потребами «Політ з одним крилом» [16]. Визначення «особливі потреби» не $\epsilon$ коректним та може стосуватися не лише людей з інвалідністю, а й людей 3 непереносимістю лактози або людей, що хочуть додаткову подушку в літаку.

Єдиним терміном, регламентованим законом України, $є$ «людина 3 інвалідністю» [4], проте у деяких сучасник словниках є навіть опис поняття «інвалід», наприклад у такому як СУМ [15]. Вживання поняття «інвалід» можна пояснити довгою відсутністю регламентованої назви групи людей, об'єднаних одним діагнозом. Так, ще й досі активно вживається у просторічній лексиці фахова термінологія на кшталт «аутист», «даун», «шизик» і так далі.

Появу ж термінів «людина 3 особливими потребами» та «людина 3 обмеженими можливостями» можна пояснити намаганням встигнути за європейськими мовами, що вже почали швидко підлаштовуватись під інклюзивні віяння.

Але ніякі з цих термінів не можна вважати доцільними для вживання, окрім регламентованого Законом України «людина 3 інвалідністю». Також не варто акцентувати увагу на діагнозі людини без особливої потреби у контексті повідомлення, оскільки це може завдавати моральної шкоди особі.

Отже, нормативна лексика - це унормована лексика, що може вживатися у будь-яких видах мовлення і яка $є$ нейтральною стосовно будь-якого мовця. Проблема «нормативності» є актуальною сьогодні, оскільки більшість меншин не мають регламентованої законом чіткої термінології.

Тема расової та етнічної дискримінації $є$ однією з найангажованіших у ЗМК, бо має яскраво виражений криміногенний фактор. Альтернативою $\epsilon$ історично усталені слова.

Дискримінація за сексуальною орієнтацією та гендерною ідентичністю $є$ найбільш розповсюдженою та може бути навмисною для підтримання окремих настроїв у соціумі. Має історичне та релігійне підгрунтя. Нормативна лексика стосовно таких меншин не регламентована. Нейтральним джерелом можна вважати дослідження активістів та лінгвістів у цій сфері.

Люди 3 інвалідністю - єдина група серед зазначених, що має регламентовану «термінологію», але іiі все ще не використовують у ЗМК. «Інвалід», як найпоширеніше неправильне позначення, виникло в результаті утворення назви від діагнозу.

\section{Список літератури}

1. Загальна декларація прав людини. URL: https://zakon.rada.gov.ua/laws/show/99 5_015/conv. 
2. «Еврей - клоун-президент» и «Беленюк - негр»: журналист парламентской газеты разгневал сеть расистскими высказываниями. URL:https://www.unian.net/society/10581048-evrey-kloun-prezident-i-belenyuknegr zhurnalist-parlamentskoy-gazety-razgneval-set-rasistskimi-vyskazyvaniyami.html.

3. Негр з Конго напав у Тернополі на поліцейського.URL: https://provse.te. ua/2017/08/nehr-z-konho-napav-u-ternopoli-na- politsejskoho/.

4. Закон РСФСР от 27.10.60 «Об утверждении уголовного кодекса РСФСР» (вместе с «Уголовным кодексом РСФСР») https://zakonbase.ru/zakony/27-101960-ot-1960-10-27-ob-utverzhdenii/statja-121.

5. Паніна Н. Неподолана дистанція. Критика, 2003. № 7-8.

6. Закон України «Про засади запобігання та протидії дискримінації в Україні». URL : https://zakon.rada.gov.ua/laws/show/5207-17.

7. Люди з інвалідністю, яких не існує, та 40 \% українських дітей, що не можуть зробити завдання 3 батьками, - MOH пояснює, для чого потрібна антидискримінаційна експертиза підручників.

URL

: https://mon.gov.ua/ua/news/negri-zhidi-ta-cigani-lyudi-z-invalidnistyu-yakih-neisnuye-ta-40-ukrayinskih-ditej-sho-ne-mozhut-zrobiti-zavdannya-z-batkami-monpoyasnyuye-dlya-chogo-potribna-antidiskriminacijna-ekspertiza-pidruchnikiv.

8.Нетрадиційна сексуальна оріснтація вашої дитини URL : https://www.obozrevatel.com/mamaclub/vozrastnaja-psihologija/material / netraditsiyna_seksualna_orintatsiya_vasho_ditini-6151.html.

9. Постановление от 1 апреля 1934 года о дополнении уголовного кодекса РСФСР

154-A

URL

http://www.libussr.ru/doc_ussr/ussr_3977.htm?fbclid=IwAR0tF6F2nVglI6PQZW4X SkmlftGW13a4oMhj51GVMxzeQVwREn157V7gU0Q.

10. Свод законов уголовных. Книга первая. // Свод законов Российской империи, издание 1832 года. Тип. ІІ отделения Собственной Е. И. В. канцелярии, 1832. Т. $\mathrm{XV}$.

C.

213.

URL

http://unipersona.srcc.msu.ru/site/research/zajonchk/history_sprav/0001-0301.htm 11. Про внесення змін i доповнень до Кримінального i Кримінальнопроцесуального кодексів Української РСР.

URL

: http://www.libussr.ru/doc_ussr/ussr_3977.htm.

12. Словник української мови: в 11 тт. / АН УРСР. Інститут мовознавства; за ред. І. К. Білодіда. К.: Наукова думка, 1970-1980. Т. 2. С. 122.

13. Як писати про ЛГБТ. Курс для журналістів http://www.insightukraine.org/uploads/files/on-line_kurs_ukr_web.pdf.

14. Закон України «Про внесення змін до деяких законодавчих актів України щодо застосування терміна «особа з інвалідністю» та похідних від нього». URL: https://zakon.rada.gov.ua/laws/show/2581-19.

7. Мартиненко О. А. Расизм та ксенофобія як нове фонове явище злочинності в Україні.

URL

file://C:/Users/HP/Downloads/

Telegram\%20Desktop/VKhnuvs_2008_43_14.pdf.

15. «У Новояворівську відбувся фестиваль для людей з особливими потребами «Політ 
https://zik.ua/news/2019/06/11/u_novoyavorivsku_vidbuvsya_festyval_dlya_lyudey_ z_osoblyvymy_potrebamy_polit_1591105.

16. Тлумачення із «Соовника української мови» https://www.slovnyk.ua/index.php?swrd=\%D1\%96\%D0\%BD\%D0\%B2\%D0\%B0\% D0\%BB\%D1\%96\%D0\%B4. 


\title{
РОЗВИТОК КОНКУРЕНТНОГО ЗАКОНОДАВСТВА УКРАЇНИ В УМОВАХ СВРОПЕЙСЬКОЇ ІНТЕГРАЦЇ̈
}

Каверіна Віта Василівна

студентка групи Пр-301

Національний авіаційний університет

\author{
Мілімко Лариса Василівна \\ к.ю.н., доцент, доцент кафедри \\ господарського, повітряного та космічного права, \\ Національний авіаційний університет \\ Київ, Україна
}

Україна стоїть на порозі змін. I ці зміни, безпосередньо, пов'язані 3 європейською інтеграцією. Для того, щоб наша держава мала можливість увійти до складу Свропейського Союзу вона повинна пройти ряд реформ та нововведень. I, звісно, ці нововведення не могли не торкнутися господарського законодавства, а зокрема конкурентного. Тому питання імплементації норм європейського конкурентного права в національне законодавство України $\epsilon$ насущним питанням. I чим ближче Україна до членства в СС, тим більше вимог в цій сфері вона повинна виконати.

Аналіз останніх досліджень свідчить про те, що питанням розвитку українського конкурентного законодавства в процесі євроінтеграції приділяють увагу багато науковців. До них належать: О. Бакалінська, П. Верболюк, В. Грабовський, Л. Біла, О. Безух, С. Валітов, Н. Корчак, К. Смирнова та ін.

Понад п’ять років пройшло з моменту укладення Угоди про асоціацію, отже, саме час підвести підсумки процесу імплементації положень Угоди до конкурентного законодавства України.

Відповідно до Угоди Україна і ЄС узгоджують національні законодавства 3 питань конкуренції; обмінюються інформацією стосовно власних схем допомоги; не застосовують будь-яких заходів, що можуть спотворити торгівлю між країнами; у рамках Комітету з питань співробітництва проводять консультації 3 проблем конкуренції; утримуються від надання державної допомоги підприємствам з виробництва товарів або надання послуг, які спотворюють або загрожують спотворити конкуренцію; надають допомогу в розробці правил конкуренції. Крім того, відповідно до ст.ст. 254-255 Угоди Україна зобов'язалася привести чинне конкурентне законодавство у відповідність із законодавством Європейського Співтовариства. Гармонізація конкурентного законодавства України до вимог і стандартів СС $є$ провідним напрямом його розвитку [1].

Разом $з$ тим зазначимо, що норми, які підлягають імплементації в чинне конкурентне законодавство України містяться не тільки в розділі 
$\mathrm{X}$ «Конкуренція», а й в інших частинах Угоди, зокрема, забезпечення умов розвитку конкуренції в енергетичному та газовому секторі, вдосконалення правової регламентації в сфері публічних (державних) закупівель, захисту прав інтелектуальної власності, зокрема в сфері правової охорони географічних позначень та ін. [2].

Вимоги щодо адаптації Українського конкурентного законодавства до правил конкуренції СС можна згрупувати відповідно до сфери правового регулювання на чотири види, а саме: правовий режим антиконкурентних узгоджених дій, контроль за концентрацією, діяльність державних монополій та державну допомогу.

Першою умовою удосконалення матеріальних норм українського законодавства $\epsilon$ його наближення в сфері регулювання режиму винятків із антиконкурентних вертикальних угод. Статтею 256 Угоди про асоціацію передбачено адаптацію Регламенту № 330/2010, відповідно до якого вертикальна угода між підприємствами може підпадати під виключення із загальної заборони. Зокрема це вертикальні угоди про купівлю або продаж товарів або послуг, які укладені між неконкуруючими підприємствами, між певними конкурентами або певними асоціаціями рітейлерів товарів. Вона також включає в себе вертикальні угоди, що містять допоміжні положення про передачу прав інтелектуальної власності або їх використання [4].

В Угоді про асоціацію наголошено на необхідності усунення прогалин в українському законодавстві щодо правового регулювання блокових виключень для угод щодо передачі технологій. Зокрема, Регламентом № 316/2014 визначається, що угоди про передачу технологій стосуються передачі прав, що охороняються ліцензією.

Ще одним напрямом удосконалення норм конкурентного законодавства $\epsilon$ удосконалення механізму контролю за концентрацією суб'єктів господарювання. Угода про асоціацію містить додаткові вимоги щодо удосконалення правового регулювання контролю за концентраціями.

26 січня 2016 року було внесено зміни до Закону України «Про захист економічної конкуренції». У чинній редакції цього Закону визначено, що концентрація може бути здійснена лише за умови попереднього одержання дозволу Антимонопольного комітету України, якщо: - сукупна вартість активів або сукупний обсяг реалізації товарів учасників концентрації за останній рік перевищує 30 мільйонів євро, і при цьому вартість активів або обсяг реалізації товарів в Україні не менш як у двох учасників концентрації перевищує 4 мільйони євро у кожного, або - сукупна вартість активів або сукупний обсяг реалізації товарів в Україні суб'єкта господарювання, щодо якого набувається контроль або хоча б одного із засновників створюваного суб'єкта господарювання за останній рік перевищує 8 мільйонів євро, і при цьому обсяг реалізації товарів хоча б одного іншого учасника концентрації, за останній рік, у тому числі за кордоном, перевищує 150 мільйонів євро. Також в новій редакції Закону України «Про захист економічної конкуренції» з'являється спрощена процедура розгляду заяв про надання дозволу на концентрацію [3].

Ще одним зобов'язанням України є імплементація Регламенту Ради $6 C$ 
№ 1/2003. Основні запропоновані нововведення полягають у тому, що суб'єкти господарювання, які уклали договір, повинні самостійно пересвідчитися в тому, що договір відповідає конкурентному законодавству.

Стаття 258 Угоди містить зобов'язання протягом 5 років 3 моменту набуття нею чинності узгодити діяльність державних монополій, які займаються господарською діяльністю, відповідно до принципу недискримінації та добросовісної конкуренції суб'єктів господарювання та їх товарів [4].

Угода про асоціацію найбільше уваги приділяє зобов'язанням щодо необхідності заповнення прогалин в українському законодавстві в сфері державної допомоги. Ст. 262 Угоди про асоціацію містить загальне правило, відповідно до якого «будь-яка допомога, що надається Україною або державамичленами Євросоюзу через державні ресурси, яка викривляє або загрожує викривленню конкуренції шляхом створення переваг для певних підприємств чи виробництв, є несумісною із ефективним функціонуванням Угоди тією мірою, якою вона може вплинути на торгівлю між сторонами». Значним проривом в цьому напрямі стало прийняття у 2014 році Закону України «Про державну допомогу суб'єктам господарювання» [4].

Одним із завдань адаптації чинного конкурентного законодавства до вимог Угоди про асоціацію $є$ забезпечення прозорості та прогнозованості рішень антимонопольних органів, зростання прозорості діяльності Антимонопольного комітету України, що забезпечується публікацією прийнятих конкурентним відомством рішень. 3 весни 2016 року антимонопольний орган, у зв'язку 3 внесенням парламентом відповідних законодавчих змін, повинен публікувати рішення протягом 10 днів після їх прийняття, надаючи всю інформацію, крім тієї, що має обмежений доступ. Цей крок суттєво поліпшив «сприйняття» Антимонопольного комітету України як національними, так і міжнародними експертами, відкривши діяльність органу для суспільства [2].

Отже, виконуючи зобов'язання відповідно до Угоди про асоціацію 3 Європейським Союзом, Україна багато чого вже зробила. Як визначено в роботі, зазнала змін діяльність Антимонопольного комітету України, було імплементовано низку актів СС, що стосуються питань конкуренції, контролю за концентрацією та внесено багато змін до законодавства, окремі з яких ще не набрали чинності. Але процес адаптації ще не завершився, а швидше стоїть на середині шляху до досягнення своєї мети.

\section{СПИСОК ЛІТЕРАТУРИ}

1. Бакалінська О.О. Проблеми i перспективи розвитку конкурентного законодавства України. Часопис Київського університету права. 2013. № 3. С. 17 21.

2. Бакалінська О.О. Розвиток Українського законодавства і права України в умовах європейської інтеграції: веб-сайт. URL: https://coordynata.com.ua/rozvitokkonkurentnogo-zakonodavstva-i-prava-ukraini-v-umovah-evropejskoi-integracii

3. Про захист економічної конкуренції: Закон України від 11.01.2001 p. № 2210-III // URL : https://zakon.rada.gov.ua/laws/show/2210-14\#Text (дата звернення $-11.02 .2021)$.

4. Про ратифікацію Угоди про асоціацію між Україною, з однієї сторони, та 
Європейським Союзом, Свропейським співтовариством з атомної енергії і їхніми державами-членами, з іншої сторони : Закон України від 16.09.2014 № 1678-VII // URL: https://zakon.rada.gov.ua/laws/show/1678-18\#Text (дата звернення 11.02.2021). 


\title{
ПРОБЛЕМИ ЗАХИСТУ ПРАВ СУБ'СКТІВ ГОСПОДАРЮВАННЯ
}

\author{
Мельник Вероніка Сергіївна, \\ студентка групи Пр-303
}

\author{
Мілімко Лариса Василівна, \\ к.ю.н., доцент, доцент кафедри \\ господарського, повітряного та космічного права, \\ Національного авіаційного університету \\ Київ, Україна
}

Захист прав суб'єктів господарювання $є$ одним із особливих видів господарсько-правових відносин, які засновуються на принципах конституційності. Законодавець встановив, що держава гарантує дотримання прав та законних інтересів усіх суб'єктів господарювання, які є учасниками господарських відносин та здійснюють господарську діяльність, реалізуючи господарську компетенцію, а також наділені господарськими правами та обов'язками, мають відокремлене майно і несуть відповідальність за своїми зобов'язаннями в межах цього майна, крім випадків, передбачених законодавством [4].

Учасники господарювання характеризуються наявністю особливих прав $\mathrm{i}$ обов'язків, дотримання і виконання яких гарантують належний та швидкий розвиток господарської системи держави. В основу цього питання покладаються приватні інтереси суб'єктів, а посягання на такі інтереси призводять до порушення системи господарювання і як наслідок економічного розвитку країни в цілому, тому питання захисту прав суб'єктів господарювання стоїть гостро і навіть існує проблема в ефективності застосування правових норм, які регулюють захист учасників а також суб'єктів господарських відносин.

Дана проблема правового захисту суб'єктів господарювання досліджувалася у різних наукових роботах як вітчизняних науковців так і зарубіжних: В. К. Мамутова, А. Г. Бобкової, Г. Л. Знаменського, І. В. Голованя, О. В. Олейнік, І. Г. Побірченка, Н. О. Саниахметової. Але, не зважаючи на чисельність наукових досліджень, питання про застосування суб' єктами господарювання інструментів захисту своїх прав та інтересів не досить досконало вивчено та потребує подальшого дослідження.

Незважаючи на швидкий та удосконалений 3 кожним разом розвиток господарського законодавства, що регулює діяльність суб'єктів господарювання, необхідно зазначити, що нині існує досить багато відносин у сфері підприємництва та господарювання, які зовсім не врегульовані законом або іншими нормативно правовими актами, або їх регулятивний вплив $є$ досить слабким. Також невиправдана часта зміна законодавства, викликана його невисоким рівнем, неправильним співвідношенням законів і підзаконних актів, відсутністю гнучкості і належного регулятивного потенціалу [5]. На сьогодні, 
основну роль у регулюванні захисту інтересів суб'єктів господарювання виконує Господарський кодекс України. Серед великої кількості статтей, що регулюють всю господарську систему, потрібно звернути увагу на статтю 20 даного закону. Зокрема, у частині 2 зазначеної статті, визначається право кожного суб'єкта господарювання та споживача на захист прав і законних інтересів, а також формулюються способи захисту прав та законних інтересів зазначених суб'єктів. Після прочитання цієї статті, слід зауважити, що право кожного суб'єкта господарювання та споживача на захист своїх прав і законних інтересів $\epsilon$ загальним і може бути використано названою категорією суб'єктів незважаючи на те, чи передбачено це нормативно-правовим актом, яким врегульовано відносини, що виникають у зв'язку з реалізацією такого права чи законного інтересу [1, с.59]. Також слід зазначити про основні способи захисту прав і законних інтересів учасників господарських правовідносин, це:

- визнання наявності або відсутності прав;

- визнання повністю або частково недійсними актів органів державної влади та органів місцевого самоврядування, які пригнічують здійснення суб'єктами господарювання свої прав;

- відновлення становища, яке існувало до порушення прав та законних інтересів суб'єктів господарювання;

- припинення незаконних дій,які порушують права та інтереси;

- відшкодування збитків за завдану шкоду;

- застосування штрафних санкцій, оперативно-господарських або адміністративно-господарських;

- установлення, зміни і припинення господарських правовідносин тощо.

Наведений вище перелік способів захисту прав і законних інтересів учасників господарських-правовідносин не $\epsilon$ вичерпним, а тому можна зазначити, що захист прав може здійснюватися за допомогою інших способів, передбачених законодавством [4]. Проте і на цьому етапі існує проблема, яка відкривається в наступному: українським законодавством не передбачено всіх дієвих способів захисту прав, які б на реальному рівні могли б захищати права та інтереси суб'єктів господарювання. Тому, на жаль, на сьогоднішній час, суди, органи державної влади та суб'єкти господарювання обмежені лише тими способами захисту, які прямо прописані в законодавчих актах, та для яких передбачений механізм реалізації [3, с.27]. Отже, існує реальна необхідність у вдосконаленні правового механізму виконання вимог та норм, передбачених ГК України. I в даному аспекті, для вирішення цієї проблеми, найдоцільнішим є використання досвіду зарубіжних країн, які пройшли досить тривалий шлях розвитку у сфері захисту прав суб'єктів господарювання. Таку позицію висвітлив В. Петруня, який відзначив, що використання зарубіжного досвіду та прийняття дієвих змін до ГК України підвищить ефективність захисту суб'єктів господарювання. Але й самі суб'єкти повинні активно боротися 3 порушеннями закону 3 боку державних органів та захищати свої права, використовуючи всі зазначені способи захисту прав, які надані їм відповідним законодавством. Проте у цій справі існує чимало специфічних труднощів, у тому числі суто юридичного 
характеру, подоланню яких може сприяти використання поступового практичного досвіду та відповідного наукового забезпечення [2, с. 521].

Враховуюче вище наведене, а також всі позиції, можна дійти до висновку, що на сьогоднішній день існує гостра проблема практичного застосування норм, що регулюють основні способи захисту суб'єктів господарювання. I основна роль в цьому питанні належить ГК України, який охоплює всі сфери господарської діяльності. Окрім зазначеного положення, правозахисні норми містяться і в інших нормативних актах України: Конституції України, Цивільному кодексі, Трудовому кодексі тощо. Але з помітним розвитком економічного потенціалу нашої держави, питання вирішення господарських спорів та захисту прав суб'єктів господарювання, є одним із пріоритетних завданням українського законодавства.

\section{СПИСОК ВИКОРИСТАНИХ ДЖЕРЕЛ:}

1. Лаврін О. Захист прав суб’єктів господарювання, його форми та способи / О.Лаврін // Підприємництво, господарство та право. -2002. -№ 11. -С. 59.

2. Петруня В. В. Проблема ефективності використання способів захисту прав суб'єктів господарювання / В. В.Петруня // Актуальні проблеми держави і права. -2012. -№ 63. - С. 520-527.

3. Про форми захисту прав суб'єктів господарювання // Українське комерційне право. -2007 . - № $8 .-80$ с.

4. Господарський кодекс України: Закон України від 16 січня 2003 р. [Електронний ресурс]. - Режим доступу: http://zakon3.rada.gov.ua/laws/show/43615

5. Мізіна Т. О. Проблеми захисту прав суб'єктів підприємницької діяльності I T. О. Мізіна. - [Електронний ресурс ]. Режим доступу: http://www.confcontact.com/2008oktInet_tezi/ur_mizina.php 


\title{
РЕКЛАМА В ГОТЕЛЬНО-РЕСТОРАННІЙ СПРАВІ ЯК ІНСТРУМЕНТ ПРОСУВАННЯ ПОСЛУГ
}

\author{
Бортников Євгеній Геннадійович, \\ доцент, кандидат геол.-мін. наук, \\ доцент кафедри туризму і готельно-ресторанної справи, \\ Запорізький національний університет
}

Бадло Ніка, студентка

Незважаючи на певну стагнацію, пов'язану з пандемією коронавірусу, загалом готельний бізнес нині позначений зростанням. Попит на якісний відпочинок стимулює попит на послуги готелів та ресторанів - і в Україні, i за їі межами. Понад 80\% потенційних споживачів готельних послуг шукають інформацію за допомогою провідних пошукових систем українського інтернету: Googl (92,27\%), Yandex (5,67\%), bing (0,58\%), Yahoo! (0,53\%) [1]. Пошук здійснюється на сайтах численних туроператорів та безпосередньо. Для готелів та ресторанів реклама в пошукових системах дає змогу:

- по-перше, розповісти про свої послуги «з перших вуст»;

- по-друге, залучити клієнтів без посередників (турфірм і туроператорів).

Реклама готелів у пошукових системах стає все актуальнішою і потребує до себе все більшої уваги. Насамперед, така реклама дешевша від традиційної зовнішньої реклами, до того ж, на порядок ефективніша від усіх інших видів реклами [2].

Відтак стає зрозумілим, чому реклама готелів та ресторанів в інтернеті набуває такого розвитку. Вона починається з необхідності створення власного якісного інформативного сайту, якому необхідне просування - і через пошукові системи, і з використанням інших видів реклами в інтернеті (медійна, контекстна реклама, influence-маркетинг, контент-маркетинг, діджитал-маркетинг тощо) [3].

Усе більша кількість постачальників готельних послуг з'являється в цьому секторі, що створює значну конкуренцію серед готелів. Звичайно, існує безліч механізмів продажу готельних послуг i залучення клієнтів, але, мабуть, найефективнішим і простим на сьогодні є реклама.

Реклама, зокрема, в сфері готельного та ресторанного справи, покликана вирішувати такі завдання:

- надавати населенню інформацію про місце, форми, методи обслуговування, вартість та терміни виконання замовлень;

- упливати на формування попиту на послуги, щоб збільшити обсяг їх реалізації та знизити вплив сезонності;

- формувати естетичні смаки клієнтів. 
Будь-яка ефективна реклама повинна містити такі компоненти: оригінальне сценарне й композиційне рішення; високу естетичну й стилістичну виразність; служити маркетинговим інструментом [4].

Особливості реклами готельної та ресторанної справи:

- неособистий характер;

- одностороння спрямованість;

- інформаційна насиченість;

- громадський характер;

- комплексність тощо.

Отже, реклама - це те, що дає змогу споживачем дізнатися про появу нового продукту або його вдосконалення; рекламою користуються, тією чи іншою мірою, всі підприємства - від малого бізнесу до організацій, які вже не залежать від неї. Наприклад, ресторани швидкого харчування McDonald's, які поширені по всьому світу і, здавалося б, реклами не потребують. Однак компанія відзначилася оригінальними рекламними ідеями по всьому світу, які часом просувають окремий продукт або акцію [5].

Рекламу також розглядають щодо іiі впливу на цільову аудиторію, концентрації на певному сегменті, охоплення певної території, за джерелами фінансування та залежно від засобів поширення. Реклама готелю або ресторану невід'ємний атрибут готельного бізнесу. Завдяки рекламі люди можуть дізнатися про існування готелю.

Розглянемо види і способи просування готелю в інтернеті. Просування готелю (або, по-іншому, «пошукова оптимізація сайту» або «розкрутка» сайту готелю) - це процес виведення посилання на сайт готелю в ТОП-10 за результатами пошуку в пошукових системах Google i Яндекс. Такий метод просування готелю дасть безліч переходів на сайт готелю або ресторану, але сам процес виведення сайту в ТОП-10 займе від двох до чотирьох місяців. Для цього доведеться попрацювати над змістом сайту і розміщенням зовнішніх посилань.

Контекстна реклама готельно-ресторанних послуг - найбільш ефективний метод реклами готелю в інтернеті. Контекстна реклама готелю та ресторану в ньому - це коротке текстове оголошення, яке показується праворуч і під пошуковим рядком у відповідь на певний запит користувача. Така реклама готелю показується не всім користувачам, а тільки тим, які «поставили» потрібне нам питання пошуковій системі. Особливо продуктивна контекстна реклама готелю для інформування та залучення клієнтів за допомогою акцій i спецпропозицій (наприклад, «три доби проживання за ціною двох» або «сніданок у подарунок» «Молодятам - святкова вечеря»), оскільки запускається за лічені години. Перевага такої реклами готельних послуг полягає ще і в тому, що оплата береться тільки за перехід на сайт готелю. Контекстна реклама готелю англійською мовою (у пошукових системах Google i Yahoo) може залучити клієнтів з усього світу.

Банерна реклама готелю або ресторану - ще один потужний інструмент залучення клієнтів. Банер - це графічна або анімаційна картинка, яка прив'язується до ключових слів і показується тільки у відповідь на потрібний 
рекламодавцю запит. Відповідно, ефективність такого виду просування готелів ще вища.

Реклама готелю чи ресторану на форумах - ще один метод, який не можна ігнорувати. Постаючи перед вибором, люди вивчають різні спеціалізовані форуми, де читають відгуки та питають поради для того, щоб зважити, послугами якого готелю скористатися, - це робить форуми відмінним місцем для реклами готельних послуг. Для початку на подібному форумі варто зареєструватися, а потім уже вступати в обговорення, залишати коментарі та давати поради. Очевидна перевага полягає в тому, що менеджер готелю виступає в ролі досвідченого користувача, до порад якого дослухатимуться потенційні клієнти [6].

Таким чином, реклама готельно-ресторанного бізнесу має свої особливості, завдання, цілеспрямованість, що робить ії не настільки простим явищем, адже створити ефективну й виграшну рекламу не так просто, як може здатися.

Готельно-ресторанний бізнес останні кілька років показує непогані темпи розвитку не тільки в Україні, а й у світі. Одним з найважливіших факторів конкурентоспроможності є реклама. Готель або ресторан, чия рекламна кампанія буде більш привабливою, отримає перевагу в цій боротьбі. Очевидно, що серед різноманітних рекламних носіїв переміг інтернет, причому і Україні, і в усьому світі. Це закладено в специфіці самого бізнесу, задовольнити запити якого здатна тільки всесвітня мережа $з$ ії майже безмежними можливостями.

\section{References:}

1. Юдін А. Найпопулярніші пошукові системи в 2019. URL: http://surl.li/nlri.

2. Яка реклама найбільш ефективна? URL: http://surl.li/nlrj.

3. Ефективна реклама: на які інструменти варто витратити гроші. URL: http://surl.li/nlrl.

4. Вимоги до рекламних матеріалів. URL: http://surl.li/nlrml.

5. Креативная реклама McDonald's. URL: http://surl.li/nlro.

6. Кучечук Л. Інтернет-реклама як інноваційний елемент комплексу маркетингових комунікацій підприємств готельного бізнесу. URL: http://surl.li/nlrp.... 


\section{ПЕРСПЕКТИВНЕ ПЛАНУВАННЯ ІННОВАЦИЙНОГО РОЗВИТКУ ЗАКЛАДУ ЗАГАЛЬНОЇ СЕРЕДНЬОЇ ОСВІТИ}

Юшкіна Олена Миколаївна, заступник директора $з$ навчально-виховної роботи

Криворізька загальноосвітня школа I-III ступенів Криворізької міської ради Дніпропетровської області

Концепція інноваційного розвитку Криворізької загальноосвітньої школи IIII ступенів № 103 систематизує і конкретизує організаційно-педагогічні засади інноваційної діяльності 33СО, закладені в сучасному законодавстві України, нормативних і програмних документах органів державної влади, i, разом 3 іншими стратегічними документами у галузі освіти, є основою для інноваційного розвитку школи, а також подальшої розбудови нормативно-правової, науковотеоретичної і методичної бази у цій сфері. Концепція розроблена з урахуванням, 3 одного боку, необхідності дотримання вимог держави до модернізації сучасного 33СО з метою підвищення доступності й якості освітніх послуг $\mathrm{i}, 3$ іншого - активізації діяльності закладу щодо організації i здійснення інноваційного розвитку. Концепція базується на духовних $\mathrm{i}$ суспільних цінностях, які склалися в культурному просторі України впродовж багатьох століть, наголошує на необхідності їх збереження і втілення в процесі інноваційного розвитку З3СО.

Виходячи з основних положень стратегії Концепції, було визначено її мету, структуру, специфіку.

Мета Конщепйї - визначення основних напрямів і чинників переходу $33 \mathrm{CO}$ 3 режиму функціонування в режим керованих інноваційних змін, а саме: змін педагогічної системи школи, iї компонентів (освітнього, дидактичного, виховного, управлінського, матеріально-технічного тощо) та їх структурних елементів, які приводять до якісно нового рівня загальної середньої освіти, суттєво поліпшують результати діяльності закладу освіти.

Стратегія Конщепиії - закладання основ стійкого інноваційного розвитку З3СО як провідного чинника підвищення якості загальної середньої освіти та розвитку освітньо-педагогічної практики.

Концепція складається з аналітичної та стратегічної частин. У першій, аналітичній, частині сформульовано освітні і соціально-педагогічні проблеми сучасного ЗЗСО. Ці проблеми спроектовані на існуючий стан інноваційного розвитку загальної середньої освіти в Україні. Надано характеристику основних позитивних і негативних тенденцій, які відмічаються в закладі освіти, адекватні відповіді на які можливі в умовах переходу $33 \mathrm{CO}$ з режиму функціонування до режиму інноваційного розвитку.

Друга, стратегічна, частина окреслює ключові перспективні цілі, основні стратегічні пріоритети, визначає напрями і можливі варіанти розв'язання проблем, визначає і обгрунтовує ключові механізми практичного впровадження Концепції. 
Особливість Концепції полягає в аналізі освітніх проблем, визначенні напрямів, провідних об'єктів і шляхів розв'язання цих проблем як через нормативно-організаційні механізми i функціональні методи управління інноваційними процесами в 33СО, так і на основі визначення організаційнопедагогічних умов, що забезпечують оптимальність інноваційного розвитку окремого ЗНЗ, а також надання рекомендацій щодо створення цих умов.

Реалізація Концепції сприятиме створенню програми інноваційного розвитку на рівні окремого З3СО, забезпеченню скоординованої діяльності місцевої влади, громади, підприємців, освітян і науковців, учнів та їхніх батьків - усіх зацікавлених учасників процесу інноваційного розвитку $33 \mathrm{CO}$. Результатом реалізації Концепції має стати утвердження моделі інноваційного розвитку 33СО, підвищення ефективності використання інтелектуального потенціалу педагогів i конкурентоспроможності випускників, досягнення сталого інноваційного розвитку сучасного закладу освіти. Розробка Концепції спонукає переглянути головні компоненти шкільної освіти: її призначення, зміст, критерії ефективності форм та методів навчання, роль шкільного підручника, функції вчителя.

Задля створення сучасного освітнього середовища необхідно:

- інтенсифікувати всі рівні освітнього процесу, підвищити його ефективність та якість за рахунок використання інформаційно-комунікативних технологій;

- побудувати відкриту систему освіти, що забезпечить кожній дитині власну траєкторію самоосвіти;

- систематизувати інтеграцію предметних галузей знань;

- розвивати творчий потенціал учнів, їх здібності до комунікативних дій, впроваджуючи інтерактивні та активні форми роботи;

- розвивати уміння експериментально-дослідницької діяльності та культуру навчальної діяльності;

- формувати інформаційну культуру учнів;

- реалізувати соціальне замовлення, обумовлене інформатизацією сучасного суспільства (підготовка фахівців у галузі інформатики та обчислювальної техніки, підготовка користувача засобів нових інтерактивних технологій).

Вирішення цих задач, можливе у разі використання в роботі навчального закладу моделі організації сучасного освітнього середовища.

При складанні перспективного плану варто керуватися певними орієнтирами, які враховують усі складові освітнього процесу.

Підставами для розробки плану $\epsilon$ необхідність удосконалення якості освітніх послуг, які надає заклад та вироблення освітньої та наукової стратегії 3 урахуванням якісних змін в українській державі.

Нормативно-правова база включає перелік законодавчих, директивних, нормативних документів, які регулюють зміст освітньої діяльності та зміни у здійснені освітнього процесу.

Мета передбачає створення умов для забезпечення доступної та якісної освіти відповідно до вимог суспільства, запитів особистості й потреб держави та забезпечення ефективного управління розвитком загальноосвітнього 
навчального закладу.

Завдання (на перспективу) полягає у створенні механізмів державногромадського регулювання якості освіти у школі шляхом:

- чіткої координації діяльності органів управління освітою та громадського інституту школи;

- переходу на систему незалежного оцінювання начальних досягнень учнів;

- забезпечення морального та матеріального стимулювання професійної самореалізації педагогічних кадрів, підвищення їхнього соціального статусу, професійного та загальнокультурного рівня, фахової майстерності;

- розвиток профільного навчання;

- запровадження освітніх інновацій, інформаційних педагогічних технологій;

- створення сприятливих умов до пошуку, підтримки та розвитку обдарованих дітей і молоді;

- підтримки дітей і молоді з особливими потребами;

- формування в учнівської молоді навичок здорового способу життя, розвиток дитячого та юнацького спорту і туризму;

- приведення матеріально-технічного стану школи у відповідність із потребами сучасної освіти;

- розвиток міжрегіонального та міжнародного партнерства, тощо.

Термін реалізації плану складає 5 років.

Етапи реалізації плану:

- організаційно-проектувальний етап: розробка Концепції розвитку школи; визначення основних стратегій, заходів і механізмів розвитку; втілення ресурсів (людських, матеріальних, фінансових) реалізації плану);

- аналітико-практичний етап: практична реалізація інноваційних складових проектів плану; організація моніторингового спостереження за результатами; координація дій;

- завершальний eman: аналіз результатів моніторингу перспективного плану; поширення позитивного досвіду; вивчення перспективи подальшої роботи.

Ресурсне забезпечення плану_включає розробку та реалізацію механізмів залучення додаткових фінансових і матеріальних ресурсів: (цільових соціальних проектів; інвестицій; благодійних внесків тощо); підвищення ефективності використання бюджетних та позабюджетних коштів; прозорість використання фінансів у загальноосвітньому начальному закладі.

Очікувані результати передбачають:

- забезпечення умов для здобуття доступної та якісної освіти відповідно до вимог суспільства, запитів особистості й потреб держави.

- системний моніторинг реалізації плану, участь батьків і громадськості у незалежному оцінюванні якості освіти. 
У планах повинно мати місце: наступність дій при досягненні мети, аналіз недоліків і конкретні заходи щодо їх усунення. Форма перспективного плану $є$ довільною.

Реформування системи освіти, яке наразі відбувається в Україні передбачає чітке бачення перспектив інноваційного розвитку закладу загальної середньої освіти. Інноваційний розвиток сучасного закладу загальної середньої освіти (далі - 33СО) - це цілеспрямований і незворотний процес, що забезпечує якісні зміни, перехід 33 СО до нового якісного стану. Інноваційний розвиток закладу освіти здійснюється переважно за допомогою цілеспрямованого внесення в його діяльність якісно нових елементів, їх взаємозв'язків i характеристик. Передумовою, умовою і змістом цих змін виступають інновації та нововведення, що забезпечують оптимальний і сталий розвиток $33 \mathrm{CO}$.

Здійснення інноваційного розвитку закладу загальної середньої освіти передбачає зміни світоглядних позицій:

- перехід від розуміння загальної середньої освіти як сфери споживання, трансляції і здобування знань - до сфери творення, а саме: особистісного розвитку учнів, освоєння і компетентного використання випускниками здобутої середньої освіти для розв'язання життєвих завдань;

- зміну домінуючого ставлення до загальної середньої освіти як до витратної галузі - на ставлення до освіти як одного із стратегічних ресурсів економічного і соціального розвитку України.

Для цього, з урахуванням специфіки системи загальної середньої освіти, необхідно погоджувати напрями експериментальних досліджень та інноваційної діяльності 33СО з пріоритетами державної і регіональної освітньої, наукової, науково-технічної та інноваційної політики.

Під час розробки перспективного плану роботи школи обов'язково враховуються існуючі та потенційні можливості педагогічного колективу; завдання, які колектив виконуватиме протягом спланованого періоду, найефективніші засоби для виконання запланованих завдань.

Найважливішим завданням планування, особливо перспективного, $\epsilon$ прогнозування. Прогнозування повинно забезпечити розв'язання поставленої стратегічної мети за допомогою наукового передбачення на основі аналізу внутрішніх і зовнішніх зв'язків навчального закладу, вивчення тенденцій розвитку. Прогнозування $є$ найважливішим інструментом прийняття стратегічних управлінських рішень. Планування, в тому числі й перспективне, повинне мати такі етапи: скрупульозна та об'єктивна оцінка стану справ у навчальному закладі; визначення мети (основної, проміжних і другорядних) i способів тї досягнення; i, нарешті, вибір методів оперативного контролю.

Основні недоліки традиційного перспективного панування в тому, що вимоги до майбутніх результатів визначаються 3 позиції сьогодення, а не 3 позицій перспективи. Бажані результати чітко не фіксуються; заходи, внесені до планів, погано пов'язуються і координуються між собою, виступаючи часто як незалежні один від одного; вони також погано ув'язуються з ресурсним 
забезпеченням.

Саме в перспективних планах мають бути визначені основні напрями педагогічного пошуку. Необхідно навчитися передбачати в перспективі зміни й урахувати їх.

При складанні перспективного плану варто керуватися певними орієнтирами, які дозволяють визначитися з пріоритетними складовими перспективного плану розвитку школи.

Важливими є наступні принципи планування:

- вибір й конкретизація заходів;

- конкретність визначення часу та виконавців;

- розумний баланс у забезпеченні функціонування та внесенні необхідних змін.

Отже, перспективний план повинен бути:

- чітким, логічним, зрозумілим;

- гнучким, що реагує на зміни в середовищі;

- визначеним у просторі й часі, розрахованим на певний період;

- мати конкретні заходи;

- мати інструментарій для виконання цих заходів;

- зважати на ресурсне забезпечення цих заходів;

- визначати виконавців і відповідальних;

- бути спрямованим на зміни в навчальному закладі;

- мати чітку мету - розвиток навчально-виховного закладу.

Обгрунтовано складений план $є$ мотиваційним стимулом колективу. 3 метою оптимального здійснення планування складати перспективний план роботи школи найдоцільніше на п'ять років.

Зміст і форми перспективного плану можуть бути різними, оскільки їх вибір зумовлюється не лише загальними педагогічними завданнями, але й показниками економічного та соціального розвитку конкретного адміністративно-територіального району, особливостями кожної школи.

Формування перспективного плану вимагає певного аналізу чи дослідження:

- процесу міграції населення;

- демографічних процесів;

- глибокого та всебічного аналізу навчально-матеріальної бази;

- прогнозування змін у навчально-виховному процесі;

- завдання щодо трудового, економічного, естетичного та фізичного розвитку учнів;

- питання виховання національної свідомості школярів, культури поведінки, дисципліни;

- профорієнтаційної роботи з урахуванням потреб виробництва, села, району, побажань учнів та їхніх батьків, перспектив розвитку міста чи села та ін. 


\section{СПИСОК ВИКОРИСТАНИХ ДЖЕРЕЛ}

1. Боумен К. Основы стратегического менеджмента: Пер. с англ. М.:Юнити, 2005.-323c.

2. Вознюк В.С. Маркетинг освітніх послуг [Навчальний посібник] / Василь Вознюк. Луцьк : Волинська книга, 2007. - 64c.

3. Інноваційний освітній менеджмент: навч.посіб. - К.: Главник, 2006.

4. Кредісов А.І., Панченко С.Г., Кредісов В.А. Менеджмент для керівників. - К.: Т-во "Знання", КОО, 1999. - 556с.

5. Литвинова Н. П. Маркетинг образовательных услуг/Н.П. Литвинова, Н.Г.Подшибякина, В.В.Шереметова-Санкт-Петербург: Издательство ТИСБИ, 2002.- $62 \mathrm{c}$.

6. Мороз І. В. Менеджмент і маркетинг в освіті [Навчально-методичний посібник] / І. В. Мороз. - К.: Освіта України, 2009. - 192 с.

7. Оболенська Т.Є. Маркетинг у сфері освітніх послуг : автореф. дис. на здобуття наук. ступеня доктора економічних наук: 08.06.02 - «підприємництво, менеджмент та маркетинг» / Оболенська Тетяна Свгеніївна. - Харківський державний економічний університет, 2002. - 33c.

8. Панкрухин А.П. Маркетинг образовательних услуг [Електронний pecypc]/А. П. Панкрухин. - Режим доступу : http://mou.marketologi.ru/

9. Педагогический маркетинг в управлении развитием образовательных систем / [П. И. Третьяков, С. И. Захаренков, М. В. Туберозова, Н. А. Шарай]. - М.: Издательство УЦ «Перспектива», 2010. - 232 с.

10. Томпсон А.А., Стрикленд А.Дж. Стратегический менеджмент. - М.: ЮНИТИ, 2005.-456с.

11. Тарасюк Г.М., Шваб Л.І. Планування діяльності підприємства: Навч. посіб. - К.: Каравела, 2006.-432с. 


\title{
PERIOPERATIVE KORREKTUR VON BLUTFLUSSSTÖRUNGEN BEI PATIENTEN MIT EINSEITIGEM PATHOLOGISCHEN NIERENHEBEL UND IHRER REHABILITATION IM POST-OPERATOR
}

\author{
Barannyk Serhiy \\ Doktor der medizinischen Wissenschaften, \\ Professor der Abteilung für Allgemeine Chirurgie \\ Medizinische Akademie Dnipropetrowsk des Gesundheitsministeriums der
} Ukraine

Ekhalov Vasily Kandidat der medizinischen Wissenschaften, außerordentlicher Professor der Abteilung für Anästhesiologie, Intensivmedizin und Notfälle FPO Medizinische Akademie Dnipropetrowsk des Gesundheitsministeriums der Ukraine

\section{Barannik Constantine}

Kandidat der medizinischen Wissenschaften, Assistent der Abteilung für Chirurgie №1

Medizinische Akademie Dnipropetrowsk des Gesundheitsministeriums der Ukraine

Dnipro, Ukraine

\begin{abstract}
Aktualität. Bei der Analyse von Literaturquellen haben frühere eigene Studien überzeugend bewiesen, dass eine einseitige Schädigung des gepaarten Nierenorgans durch einen pathologischen Prozess den Zustand der Durchblutung im Nierenparenchym beeinflusst. Letzteres führt nicht nur zu einer Verletzung des Funktionszustands der betroffenen Niere, sondern führt auch zur Entwicklung pathologischer morphologischer Veränderungen im Nierengewebe. Die gegenüberliegende Niere ist jedoch ebenfalls negativ betroffen. Letzteres wird zu einem negativen Grund für die Verlangsamung kompensatorisch-adaptiver Reaktionen auf die Wiederherstellung der Funktion des gepaarten Organs. Selbst die Niere, die nach Entfernung des Betroffenen verbleibt, kann die Gesamtfunktion nicht vollständig kompensieren und ist nicht "gesund". Die Nieren sind aufgrund ihrer funktionellen und anatomischen Merkmale ein hervorragendes Modell für die Untersuchung der Hämodynamik, mit dem mithilfe der Doppler-Bildgebung der Nierenarterien der Grad der Organschädigung bei systemischen Erkrankungen bestimmt werden kann. Die Durchblutung in ihnen ist die wichtigste regulierte Variable, die es den Nieren ermöglicht, sich an Veränderungen der Stoffwechselprozesse anzupassen und jederzeit den für sie erforderlichen Blutfluss aufrechtzuerhalten. Eine Störung des Blutflusses in
\end{abstract}


beiden Nieren bei ihrer einseitigen Niederlage wird vor allem durch den pathologischen Einfluss einer Krankheit auf die betroffene Niere und die Entwicklung durch einen reno-renalen Reflex eines stetigen Krampfes von Gefäßen eines Parenchyms einer gegenüberliegenden Niere (insbesondere in) verursacht Fälle einer akuten Krankheit). Die Freisetzung von vasoaktiven Substanzen in den Blutkreislauf verursacht eine Reihe von Gefäßreaktionen. Abwechselnde Vasokonstriktion und Vasodilatation stören den Verlauf adäquater adaptiver Reaktionen auf die Wiederherstellung der Durchblutung der Nieren. Der zusätzliche Effekt der Operation wirkt sich auch auf die angemessene Wiederherstellung der gesamten Nierenfunktion aus. Es gibt zwei Möglichkeiten, den Zustand der Durchblutung positiv zu beeinflussen: Verbesserung der rheologischen Eigenschaften des Blutes und Verhinderung oder Verringerung des Gefäßkrampfes des Nierenparenchyms.

Das Ziel der Studie. Entwicklung und klinische Anwendung einer Methode zur perioperativen Korrektur des Nierenblutflusses bei Patienten mit einseitiger Nierenschädigung.

Material und Forschungsmethoden. Eine klinische Studie wurde an 108 Patienten im Alter von 18 bis 65 Jahren durchgeführt, um Veränderungen des Blutflusses zum Nierenparenchym bei verschiedenen Arten der einseitigen Pathologie zu bestimmen, für die eine chirurgische Behandlung durchgeführt wurde. Unter den nosologischen Einheiten einer Urolithiasis gab es 51 Fälle, obstruktive Uropathie - 38 Fälle, Strikturen eines Ureters - 11, andere - 8 Fälle. Um die Auswirkungen altersbedingter Veränderungen in den Nierengefäßen auszuschließen, wurden ältere Menschen nicht in die Studie aufgenommen. Alle Patienten wurden einer RadioisotopRenographie und einer Doppler-Untersuchung der Nierenarterien unterzogen, um den Kreislaufstatus des Nierenparenchyms zu bestimmen. Umfragen von 12 klinisch gesunden Patienten wurden zur Kontrolle herangezogen. Die Patienten wurden in 2 Vergleichsgruppen eingeteilt. Patienten der Gruppe I (58 Personen), die eine traditionelle Behandlung gemäß den Protokollen der medizinischen Versorgung für eine bestimmte Pathologie erhalten haben. Patienten der Gruppe II (50 Personen), bei denen zusätzlich Maßnahmen zur perioperativen Verbesserung des Blutflusses im Parenchym beider Nieren durchgeführt wurden.

Alle Patienten wurden mit Hilfe des Philips HD11xE-Geräts einer DopplerUntersuchung der Nierenarterien unterzogen, um den Zustand der Durchblutung des Nierenparenchyms zu bestimmen. Um den Zustand der Nierenhämodynamik zu bestimmen, wurden Indikatoren wie die maximale systolische arterielle Flussrate (Vmax) und die endgültige diastolische Geschwindigkeit (Vmin) bewertet. Bei der Analyse von Doppler wurden auch die folgenden Indizes bestimmt: Widerstandsindex (IR), Pulsationsindex (PI), systolisch-diastolisches Verhältnis (DM). Die quantitative Analyse der Renographie bestimmte die Dauer des Gefäßsegments (20-60 s); Zeit bis zum Erreichen des maximalen Niveaus der Kurve Tmax (3-5 min), Halbwertszeit von 131I-Hippuran aus den Nieren - T1 / 2 (8-12 min).

Resultate und Diskussionen. Die Doppler-Untersuchung der Nierenarterien der betroffenen Niere und des Gegenteils ermöglichte es, die folgenden Veränderungen in der Durchblutung ihres Parenchyms festzustellen. Somit wurde in allen Fällen die Läsion durch eine stetige Abnahme des systolischen Blutflusses in der Arterie der 
betroffenen Niere bestimmt, die in ihrem distalen Teil am ausgeprägtesten war, was auf vorherrschende Veränderungen in den Arterien des Nierenparenchyms hinweist. Wenn Vmax in Höhe der Nierenarterie auf $0,80 \pm 0,13 \mathrm{~m} / \mathrm{s}$ (Kontrolle - 0,87 $\pm 0,03$ $\mathrm{m} / \mathrm{s}$ ) reduziert wurde, betrug Vmin in Höhe des Hauptstamms 0,25 $\pm 0,12 \mathrm{~m} / \mathrm{s}$ (Kontrolle - 0,32) $\pm 0,06 \mathrm{~m} / \mathrm{s}$ ). Das systolisch-diastolische Verhältnis (SD) betrug $3,60 \pm 0,23$. und fast 1,5-mal höher als die Kontrollanzeige $(2,70 \pm 0,23)$. Änderungen traten auch mit dem Widerstandsindex (IR) auf, der ebenfalls anstieg und auf der Ebene der Nierenarterie 0,69 $\pm 0,09$ betrug (Kontrolle - 0,63 $\pm 0,05$ ). Der Pulsindex (PI) betrug 1,37 $\pm 0,06$ (Kontrolle - 1,27 $\pm 0,06$ ), was ebenfalls seinen Kontrollwert übertrieb. Die Zunahme des peripheren Gefäßwiderstands bei einseitigem Nierenversagen, insbesondere bei akuter Obstruktion, ist mit einem erhöhten Druck im Beckensystem verbunden, der eine Zunahme von Prostaglandinen und anderen vasoaktiven Substanzen hervorrufen kann, die wiederum eine Vasokonstriktion verursachen, die ebenfalls unterstützt wird durch Reizung. Gefäßendothel und zusätzliche Stimulation der Prostaglandinfreisetzung. All dies kann während der Doppler-Untersuchung festgestellt werden.

Die Untersuchung der Hämodynamik auf der Ebene des Parenchyms der betroffenen Niere zeigte die folgenden Veränderungen. Somit wurde Vmax in den Segmentarterien der betroffenen Niere um fast $20 \%$ - auf 0,42 $\pm 0,05 \mathrm{~m} / \mathrm{s}$ (Kontrolle - 0,52 $\pm 0,05 \mathrm{~m} / \mathrm{s}$ ) und auf der Ebene der Interlobararterien um fast 10\% - reduziert bis $0,24 \pm 0,04 \mathrm{~m} / \mathrm{s}$ (Kontrolle - 0,34 $\pm 0,04 \mathrm{~m} / \mathrm{s}$ ). Gleichzeitig nahmen auch die Indikatoren für einen Widerstandsindex und einen Pulsindex ab. Auf der Ebene der Segmentarterien betrug der IR-Wert 0,47 $\pm 0,08$ (Kontrolle - 0,60 $\pm 0,04$ ) und 0,41 \pm 0,08 (Kontrolle - 0,58 \pm 0,05) auf der Ebene der Interlobararterien des Parenchyms. Der PI lag auf der Ebene der Segmentarterien - 0,95 $\pm 0,09$ (Kontrolle - 1,23 $\pm 0,09$ ) und 0,83 $\pm 0,08$ (Kontrolle - 1,17 $\pm 0,08$ ) auf der Ebene des Parenchyms der Interlobararterien. Die relative Abnahme des Index im Vergleich zum Widerstandsindex auf der Ebene der distalen Nierenarterie ist mit der Abgabe von Blut durch arteriovenöse Shunts verbunden. Bestimmte Veränderungen des Nierenblutflusses bei einseitigen einseitigen Läsionen korrelierten mit dem Grad der Läsion und dem Alter der Patienten (unter Berücksichtigung altersbedingter Veränderungen der Blutgefäße mit einer Abnahme ihrer Elastizität).

Die renographische Untersuchung ergab fast ähnliche Veränderungen der Verschlechterung des Blutflusses in der betroffenen Niere. Somit betrug die Dauer des Gefäßsegments $67 \pm 2,4$ s (normal - 20-60 s), die Zeit bis zum Erreichen des maximalen Niveaus der Kurve Tmax $8 \pm 1,1$ min (normal - 3-5 min), die Halbwertszeit von 131IHippuran aus den Nieren - T1 / $224 \pm 3,2$ min (Norm - 8-12 min).

Es ist bekannt, dass die gegenüberliegende Niere aufgrund einer Reihe von kompensatorisch-adaptiven Veränderungen in ihrem Gefäßbett und dementsprechend einer Erhöhung der Funktionsbelastung den Hauptteil der Gesamtfunktion der Nieren übernimmt. Die gegenüberliegende Niere ist aber auch vom reno-renalen Reflex betroffen, der die kompensatorische Anpassung ihres Blutflusses beeinträchtigen kann. Die Bestimmung des Hämodynamikzustands der Nierenniere zeigte die folgenden Werte. Vmax in Höhe der Nierenarterie wurde auf $0,90 \pm 0,16 \mathrm{~m} / \mathrm{s}$ (Kontrolle - 0,87 $\pm 0,03 \mathrm{~m} / \mathrm{s}$ ) erhöht, und Vmin in Höhe des Hauptstamms betrug $0,38 \pm 0,11 \mathrm{~m} / \mathrm{s}$ 
(Kontrolle -) 0,32 $\pm 0,06 \mathrm{~m} / \mathrm{s}$ ). Der Anstieg der Blutflussrate war von Natur aus kompensatorisch ausgeprägt. Mit dem Widerstandsindex und dem Pulsindex traten geringfügige Änderungen auf. Somit stieg die IR leicht an und war gleich der Nierenarterie 0,57 $\pm 0,16$ (Kontrolle - 0,63 $\pm 0,05$ ). Der PI betrug - 1,55 $\pm 0,08$ (Kontrolle - 1,27 $\pm 0,06$ ). Letzteres weist auf eine gewisse Diskrepanz zwischen der Gesamtkapazität des Blutstroms der gegenüberliegenden Niere und der kompensatorischen Erhöhung der Blutflussgeschwindigkeit hin.

Die Untersuchung der Hämodynamik auf der Ebene des Parenchyms der gegenüberliegenden Niere zeigte die folgenden Veränderungen. Somit war Vmax in den Segmentarterien der gegenüberliegenden Niere auf $0,58 \pm 0,06 \mathrm{~m} / \mathrm{s}$ erhöht (Kontrolle - 0,52 $\pm 0,05 \mathrm{~m} / \mathrm{s}$ ), und auf der Ebene der Interlobararterien stieg diese Zahl weniger deutlich an und betrug 0,35 $\pm 0,04 \mathrm{~m} / \mathrm{s}$ (Norm - 0,34 $\pm 0,04 \mathrm{~m} / \mathrm{s}$ ). Änderungen im Widerstandsindex wurden ebenfalls festgestellt. Auf der Ebene der Segmentarterien betrug die IR 0,31 $\pm 0,06$ (Kontrolle - 0,60 $\pm 0,04$ ) und blieb auf der Ebene der Interlobararterien ebenfalls unverändert - ebenfalls - 0,31 $\pm 0,06$ (Kontrolle - $0,58 \pm 0,05)$. Änderungen werden auch in PI vermerkt. Auf der Ebene der Segmentarterien betrug sein Wert - 0,62 $\pm 0,04$ (Kontrolle - 1,23 $\pm 0,09$ ) und 0,63 \pm 0,09 (Kontrolle $-1,17 \pm 0,08$ ) auf der Ebene der Interlobararterien des Parenchyms. Die Abnahme des Resistenzindex entspricht der relativen Nichtübereinstimmung der Gesamtkapazität selbst des kompensatorisch reorganisierten Blutflusses der gegenüberliegenden gesunden Niere. Die kompensatorische Steigerung seiner Funktion ist jedoch auf eine intensive Zunahme der Stoffwechselprozesse zurückzuführen. Der aussagekräftigste Indikator war der Widerstandsindex.

Unter Berücksichtigung des oben Gesagten haben wir das folgende Schema einer perioperativen Methode zur Korrektur des Blutflusses in beiden Nieren bei einseitigen Läsionen entwickelt und getestet, die eine Operation erfordern. Alle Patienten in der Versuchsgruppe erhielten eine Behandlung gemäß den Protokollen der medizinischen Versorgung entsprechend der Art der Krankheit. Der chirurgische Eingriff wurde in ausreichender Menge durchgeführt, um den pathologischen Prozess und seine Folgen mit intraoperativen Maßnahmen zur Wiederherstellung des Funktionszustands der betroffenen Niere zu beseitigen. Unter Berücksichtigung der erhaltenen Ergebnisse der klinischen Erforschung des Blutflusses, experimenteller Daten zur Modellierung pathologischer Zustände mit anhaltender Störung des Blutflusses und der Urodynamik wurden die Bedingungen der größten Durchblutungsstörung bestimmt: 3., 7.-10., 14 Tage. Um den Krampf der Gefäße des Nierenparenchyms zu beseitigen, verschrieben Medikamente, die zur Gruppe der sympatholytischen Substanzen gehören und keine adrenolytischen Wirkungen hervorrufen. Sie wurden 3 Tage vor der Operation und 2 Wochen nach der Operation angewendet. Die Ernennung von Antikoagulanzien vor der Operation und für 3 Tage nach der Operation war obligatorisch. In der postoperativen Zeit für 2 Wochen verschrieben Disaggreganten. In der postoperativen Fernperiode von bis zu 3-4 Monaten wurden den Patienten Phytopräparationen angeboten, die entzündungshemmend, krampflösend und antiseptisch wirken. Um die Qualität der Wiederherstellung des Blutkreislaufs im Nierenparenchym nach vollständiger Aktivierung der Patienten nach einer Operation von 10 bis 14 Tagen zu kontrollieren, wurde die Untersuchung des Blutflusses unter Verwendung einer 
Ultraschall-Doppler-Untersuchung oder einer Radioisotop-Renographie durchgeführt. Die entwickelte Methode wird zur Behandlung von 50 Patienten mit einseitiger Nierenschädigung eingesetzt.

Nach perioperativer Korrektur des Nierenblutflusses bei Patienten mit einseitiger Nierenschädigung über 10 bis 14 Tage war eine Abnahme der IR an der Nierenarterie der betroffenen Niere auf 0,64 $\pm 0,24$ gegenüber 0,69 $\pm 0,09$ bei einem Anstieg des Widerstandsindex der Segmentarterien zu verzeichnen auf $0,50 \pm 0,16$ gegenüber 0,47 $\pm 0,08$ und an den interlobulären Arterien $0,45 \pm 0,24$ gegenüber $0,41 \pm 0,08$. Diese Daten deuten auf eine Verbesserung des Blutflusses hin, diese Verbesserung hing jedoch eher mit den Folgen einer chirurgischen Behandlung zur Beseitigung des pathologischen Prozesses zusammen. Änderungen in der Rate der gegenüberliegenden gesunden Niere waren wie folgt. An der Nierenarterie betrug ihr Wert 0,55 $\pm 0,14$ gegenüber dem Anfangswert von 0,57 $\pm 0,16$, an den Segmentarterien - 0,29 $\pm 0,24$ gegenüber $0,31 \pm 0,06$ und an den interlobulären Arterien - 0,29 $\pm 0,16$ gegenüber 0,31 $\pm 0,06$. Das heißt, die Veränderungen zeigten systematisch eine Verbesserung des Blutflusses um 7-8\%.

Schlussfolgerungen. Die medikamentöse Korrektur des Blutflusses in den Nieren von Patienten mit einseitigen Läsionen in der perioperativen Phase ermöglicht nicht nur eine Verbesserung um 7-8\%, sondern schafft auch günstige Bedingungen für angemessene adaptiv-kompensatorische Reaktionen zur Wiederherstellung des Funktionszustands von beide Nieren.

\section{Referenzenliste:}

1. Баранник С.І., Стусь В.П., Бараннік К.С. Хвилеподібна відповідь судинних реакцій нирок на їх однобічне ураження. Південноукрайнський медичний науковий журнал. 2017. №17(17) червень. С. 8-10.

2. Квятковський Є.А., Хархота В.Б. Становище ниркової гемодинаміки єдиної нирки за даними ультразвукової доплерометрії. Урологія. 2000. T. 4. №4. C. 41-44.

3. Люлько О.В., Пепенін С.В., Світличний Е.О. Морфологічні та функціональні механізми адаптації єдиної нирки, яка залишилася після видалення контралатеральної. Медичні перспективи. 2001. T. VI. №4. С. 87-91.

4. Стусь В.П., Бараннік К.С. Компенсаторні можливості протилежної нирки при різних видах однобічного порушення кровообігу в експерименті. Південноукраӥнський медичний науковий журнал. 2015. №10(10) січень. С. 86-88.

5. Стусь В.П., Бараннік К.С. Функціональний стан і компенсаторнопристосовні можливості парного органа - нирок в умовах однобічного ураження або єдиної нирки, що залишилася після нефректомії (огляд літератури). Урологія. 2016. №1 (76). C. 5-16.

6. Stus V., Trofimov M., Barannik K. Medicamentous correction of the kidneys blood-groove in perioperatione the period. The XVIII European Society of Surgery (ESS) Meeting \& The 17th Spring Annual Congress of the Lebanese Society for General Surgery (LSGS). 2014. P. 53.

7. Патент на корисну модель №111114 України «Спосіб медикаментозної корекції порушеного кровотоку нирок при однобічному їх ураженні у періопераційному періоді» / В.П. Стусь, С.І. Баранник, В.В. Схалов, К.С. 
Бараннік. Заявка № u201608456; подана 01.08.2016; вид. 25.10.2016. Опубл. 25.10.2016, Бюл. №20. 


\section{ВІКОВІ ОСОБЛИВОСТІ ПАЦЕНТІВ 3 ХВОРОБАМИ ЦНС ТА СПЕЦИФІКА РОБОТИ ФАХІВЦЯ 3 ФІЗИЧНОЇ ТЕРАПІЇ 3 РІЗНИМИ ВІКОВИМИ ГРУПАМИ}

\section{Єрназарова Ярослава Ярославівна}

магістр з фізичної терапії, реабілітолог Медичний реабілітаційний центр "Прометей”

“Взаємовідносини медичного працівника і хворого - це не просто обмін інформацією, це - частина лікування" [1, с.11], подібна думка на сьогодні стабільно закріпилася у різних практиках лікування та реабілітації пацієнтів.

Перше, з чого починається реабілітація - це налагодження контакту. Не має значення, скільки років пацієнтові - 5, 17, 33, 51, 68, 80 - без контакту не буде довіри, а без довіри пацієнт не почне максимально віддаватися задля найкращого результату реабілітації. Важко сказати, з якою віковою категорією легше всього встановлювати контакт, тут все дуже індивідуально. Проте без такого контакту ефективність взаємодії з пацієнтом буде мінімізована.

Під час різних практик періоду навчання, а також у роботі з особливими дітьми та взаємодії з їхніми батьками у Медичному реабілітаційному центрі “Прометей” (м. Київ, Україна) для мене стало очевидним: не варто боятися ані пацієнтів, ані їх родичів, що ними опікуються. Навіть якщо медик або реабілітолог спочатку психологічно не готовий працювати з особливими дітьми, в яких, наприклад, ДЦП або інші серйозні діагнози, йому доведеться шукати емоційний контакт задля ефективної взаємодії у лікуванні та реабілітації. Не варто боятися посміхнутися дітям, заговорити до їх батьків, поцікавитися їх анамнезом та очікуваннями, з якими вони прийшли. Також конкретно у нашій практиці не слід боятися працювати 3 різними патологіями - наприклад, гіпотонічним або спастичним станом м'язів пацієнтів, їх контрактурами, комплексними складними станами. У нашому центрі всі розуміють, що незалежно від патології діти залишаються дітьми - вони сміються, якщо їх лоскотати, їм подобаються яскраві кольори, цікаві історії, казкотерапія тощо. 3 батьками таких дітей також важливо встановити певну довіру, і для цього фахівцю з фізичної терапії потрібно значно більше психологічних знань, аніж забезпечує вища освіта у галузі фізичної терапії.

Фізичний терапевт має бути в певній мірі і психотерапевтом. "Психотерапія $\epsilon$ одним 3 основних компонентів реабілітаційної програми" [2]. Різні захворювання, різні стани, різні прогнози - це те, з чим він стикатиметься щоденно. Він матиме справу з різними віковими категоріями людей і повинен буде враховувати особливості цих вікових груп. Не секрет, що люди літного віку значно менше вмотивовані, що батькам хворих дітей дуже складно морально, що чим складніша патологія, тим важчим і довшим буде процес часткової або повної реабілітації. У всіх цих ситуаціях хороший фахівець із фізичної терапії буде дуже тонко виконувати певну психотерапевтичну функцію, адже він матиме те, чого не матиме більша частина інших медичних працівників, а саме 
- тілесний контакт, і це варто обов'язково використати для встановлення довіри та стійкого психоемоційного зв'язку.

Сучасні українські лікарі-дослідники Л.Танцура, О.Сгоркіна, В.Мартинюк, М.Пітик та інші приділяють чималу увагу особливостям захворювань нервової системи у дітей, оскільки і перебіг хвороб, і лікування дитячого організму мають свою специфіку порівняно з дорослими [3]. Проте, незалежно від видів і форм патологій, діти є відкритішими для психоемоційної взаємодії, аніж люди літнього віку. Тому під час роботи з дітьми варто враховувати наступне:

1. загальну ефективність реабілітації дітей підвищує ігрова форма занять або процедур;

2. для дітей надто важливо, аби їх сприймали як особистостей, а не як носіїв певної патології;

3. діти відкриті до сприйняття ритму, музики, звуконаслідувань;

4. діти більш підвладні несвідомим реакціям у відповідь на комфортну/некомфортну атмосферу у закладі в цілому.

У людей похилого віку майже завжди наявна поліморбідність, спад фізичних якостей (наприклад, зниження сили та витривалості, збільшення часу відновлення). Нерідко це суттєво ускладнює процес реабілітації, адже варто враховувати багато вікових особливостей та змін організму, усі показання i протипоказання: «це призводить до гіпердіагностики, поліпрагмазії, невиправданого збільшення вартості лікування, відсутності позитивної динаміки терапії. Звісно, всі ці фактори підвищують навантаження лікаря і при цьому не приносять очікуваного полегшення пацієнтові» [4]. Втім, головним аспектом $€$ наявність бажання покращити свій стан та готовність брати у цьому безпосередню активну участь. Проте у більшості пацієнтів, наприклад, після перенесеного інсульту - в 30-67\% випадків - розвиваються психоемоційні розлади, а постінсультна депресія в рази збільшує летальні наслідки перенесеного інсульту [5].

У навчальному посібнику “Основи фізичного виховання людей різного віку” зазначено: "з віком погіршується діяльність нервової системи, знижується подразнення кори головного мозку, зменшується рухливість нервових процесів. Фізична активність активує нервову систему, пришвидшує проходження нервових процесів" [6, с.105]. Наприклад, лише людям літнього віку властива ізольована систолічна гіпертонія - підвищується тільки систолічний тиск.

Старіння загалом є руйнівним процесом, що невідворотно призводить до зниження фізіологічних функцій організму людини та спричиняє в ньому вікові дегенеративні зміни. У цей період людина стає “особливо захищеною i вразливою, загострюються наявні і виникають нові соматичні та психічні захворювання" [7].

Варто враховувати наступні фізіологічні особливості людей похилого віку:

1. зниження компенсаторно-пристосувальних реакцій;

2. порушення складних форм психічної діяльності;

3. розлади емоційної сфери;

4. когнітивні розлади тощо.

Найтиповішими захворюваннями похилого віку 3-поміж нервових та 
судинних хвороб справедливо вважають енцефалопатію (атеросклеротичну хронічну недостатність мозкового кровообігу на тлі атеросклерозу i гіпертонічну - хронічну недостатність мозкового кровообігу на тлі артеріальної гіпертензії), гострі порушення мозкового кровообігу, хворобу Альцгеймера та хворобу Паркінсона. Суттєве збільшення статистичних показників нейродегенеративних захворювань у світі частково пояснюється тим, що у розвинених країнах суттєво збільшується середня тривалість життя: «У $2001 \mathrm{p}$. доля осіб похилого віку у соціумі склала $60 \%$ з прогнозованим збільшенням до $71 \%$ до 2040 р. Така тенденція неминуче призводить до збільшення у популяції кількості осіб із віковими захворюваннями» [8].

Т.Хомзазюк і Ю.Кротова називають вік одним із факторів, що впливають «на рівень інвалідизації, якість життя і соціальну адаптацію пацієнтів» [9]. Л.Міщенко вважає вік суттєвим фактором ризику щодо виникнення систолічної $\mathrm{AГ:} \mathrm{«з} \mathrm{віком} \mathrm{знижується} \mathrm{активність} \mathrm{ренінангиотензивної} \mathrm{та}$ симпатоадреналінової систем, що регулюють рівень АТ в організмі, жорсткість судин підвищується, при цьому активність реніну у плазмі крові знижується, внаслідок чого підвищується САТ» [10].

Н.Бачинська поділяє спектр когнітивних порушень при старінні на наступні групи:

1. Легкі когнітивні порушення (зміни, пов'язані з віком, синдром легких когнітивних порушень, вікова когнітивна дисфункція);

2. Помірні когнітивні порушення (синдром помірних когнітивних порушень;

3. Тяжкі когнітивні порушення (деменція) [11].

Відтак фізична реабілітація хворих людей похилого віку має свою специфіку, оскільки після 45 років хвороби людини починають акумулюватися (йдеться не про арифметичне накопичення хвороб, а про індивідуальний набір хвороб у кожної людини). Зазвичай, пацієнти старше 60 років мають мінімум 5 хронічних хвороб одночасно. При цьому можуть не збігатися також паспортний і біологічний вік людини.

Для всіх захворювань нервової системи у людей літнього віку характерною $\epsilon$ малосимптомність, чим суттєво ускладнюється діагностика.

Утім, попри традиційне уявлення про «вікозалежний характер хвороби Паркінсона» [12], випадки захворювання молоді істотно частішають, у зв'язку з чим навіть йдеться про окрему підгрупу - «хвороба Паркінсона 3 раннім початком»: відрізняються механізми розвитку хвороби, клінічна картина, перебіг, реакція на протипаркінсонічні препарати. У ранньому віці розвитку цієї хвороби практично виключається позитивна динаміка i в такому випадку пацієтові важливо надавати кваліфікований психологічний супровід.

Таким чином, медик або реабілітолог має бути підготовлений до психологічної взаємодії з різновіковими пацієнтами та тими, хто опікується хворими людьми. Бажано щоб у випускників відповідних спеціальностей університетів був сформований відповідний набір компетентностей, оскільки зараз фахівцеві доводиться або працювати на інтуїтивному рівні, або займатися додатковою самоосвітою. 


\section{Список використаних джерел:}

1. Назар ПС, Шахліна ЛГ. Загальний та спеціальний догляд за хворими 3 елементами фізичної реабілітації: навч. посіб. К.: Олімпійська література; 2006. 240c.

2. Самойленко ВБ, Яковенко НП, Петряшев IO та ін. Медична і соціальна реабілітація: підручник. К.: ВСВ «Медицина»; 2018. 464 с.

3. Колесник М. Захворювання нервової системи у дітей: сучасні підходи до діагностики та терапії. Украӥнський медичний часопис: Актуальні питання клінічної практики. 2019;1:20-23.

4. Полякова Д. Современный подход к терапии психосоматических заболеваний с помощью препарата седаристон. Український медичний часопис: Актуальні питання клінічної практики. 2019;4:49-51.

5. Ошевенский ЛВ, Крылова ЕВ, Уланова ЕА. Изучение состояния здоровья человека по функциональным показателям организма: методические указания. Новгород: Нижегородский ГУ имени Н.И.Лобачевского; 2007. 67с.

6. Литовченко ГО, Козерук ЮВ, Лазаренко МГ, Трояновська ММ. Основи фізичного виховання людей різного віку: навч. посіб. К.: Кондор-Видавництво; 2016. 224c.

7. Маруненко IM, Тимчик ОВ. Медико-соціальні основи здоров'я: навч. посіб. для студ. вищ. навч. закл. К.: Київськ. ун-тет імені Бориса Грінченка; 2013. $316 \mathrm{c}$.

8. Осадчий О. Базисная терапия болезни Альцгеймера: современные тенденции. Український медичний часопис: Актуальні питання клінічної практики. 2019;1:79-82.

9. Хомазюк ТА, Кротова ВЮ. Фактори ризику когнітивних порушень при артеріальній гіпертензії. Український медичний часопис: Актуальні питання клінічної практики. 2019;2:34-36.

10. Колесник М. Артериальная гипертензия в практике семейного врача: выбор правильной тактики терапии. Украӥнський медичний часопис: Актуальні питання клінічної практики. 2019;3:3-4.

11. Марчук М. Когнітивні порушення: критерії, формулювання діагнозу і терапевтична практика. Украӥнський медичний часопис: Актуальні питання клінічної практики. 2019; 2:8-9.

12. Стасенко Т. Лікування захворювань нервової системи: сучасний погляд на клінічні аспекти. Украӥнський медичний часопис: Актуальні питання клінічної практики. 2018;5:23-26. 


\section{ЦИТОКИНОВЫЙ ДИСБАЛАНС И ИММУНОРЕАКТИВНОСТЬ НЕКОТОРЫХ СУБПОПУЛЯЦИЙ ЛИМФОЦИТОВ ПРИ ГЕПАТОСПЛЕНОМЕГАЛИИ РАЗЛИЧНОЙ ЭТИОЛОГИИ}

Климова Елена, д. биол. наук, проф., зав. диагностической лаборатории ГУ «Институт общей и неотложной хирургии им. В.Т.Зайцева» НАМН Украины

Кордон Татьяна к. биол. н., с. н. с. диагностическая лаборатория ГУ «Институт общей и неотложной хирургии им. В.Т.Зайцева» НАМН Украины

Дроздова Лариса к. биол. н., с. н. с. диагностическая лаборатория ГУ «Институт общей и неотложной хирургии им. В.Т.Зайцева» НАМН Украины

Введение. Селезенка является самым крупным периферическим лимфоидным органом, выполняющим различные функции - фильтрации крови, элиминации антигенов, кроветворении и депонировании кровяных клеток. [1]. Как лимфоидный орган иммунной системы, селезенка нередко вовлекается в патологические процессы, происходящие в организме. [2]. Увеличение размеров селезенки может являться следствием инфицирования организма, генетически детерминированных метаболических нарушений. Одновременное увеличение размеров печени и селезенки - гепатоспленомегалия - встречается достаточно часто при циррозе печени. Вовлечение селезенки в патогенез цирроза печени обусловлено анатомическим участием обоих органов в портальном кровообращении [3].

У пациентов с гепатоспленомегалией имеет место выраженная клиническая гетерогенность, при этом молекулярные и клеточные механизмы метаболических нарушений, степень обратимости метаболических расстройств остаются до конца не изученными. Прогрессирующее повреждение печени и селезенки могут быть связаны с наличием хронического воспалительного процесса на фоне инфицирования антигенами различной природы с последующим нарушением иммунореактивности и иммунорезистентности. Остается неизвестным, какова роль функциональной активности различных 
звеньев иммунного ответа у пациентов с различными этиологическими факторами гепатоспленомегалии.

Целью работы было изучение механизмов иммунологической дисрегуляции продукции цитокинов, иммуноглобулинов и изменения экспрессии класстеров дифференцировки $\mathrm{CD}$ субпопуляций Т- и В-лимфоцитов у больных с гепатоспленомегалией различной этиологии.

Материалы и методы. Материалом для исследования служили форменные элементы и сыворотка крови 73 пациентов с гепатоспленомегалией, поступивших на лечение в клинику ГУ «Институт общей и неотложной хирургии им. В.Т. Зайцева НАМН Украины» по поводу кровотечения из варикознорасширенных вен (ВРВ).

Bсе пациенты были разделены на три группы. В группу I объединили 32 пациента с циррозом печени на фоне вирусных гепатитов В или С; в группу II объединили 32 пациента с циррозом печени на фоне персистенции герпетических вирусов - цитомегаловируса (CMV) и вируса Эпштейна-Барра (VEB); в группу III объединили 9 пациентов с циррозом печени на фоне наследственно обусловленного дефекта ферментов лизосом.

Экспрессию кластеров дифференцировки CD22+ В-лимфоцитов исследовали методом люминесцентной микроскопии с помощью непрямого иммунофлуоресцентного анализа, используя моноклональные антитела, меченые FITC-красителем.

Определение концентрации сывороточных иммуноглобулинов IgA, IgM, IgG проводили методом иммуноферментного анализа (ИФА) с использованием наборов реагентов «Вектор-Бест».

Определение содержания цитокинов (интерлейкина-1 $\beta$ (ИЛ-1 $\beta$ ), интерлейкина-2 (ИЛ-2), интерлейкина-4 (ИЛ-4), интерлейкина-6 (ИЛ-6), интерлейкина-10 (ИЛ-10), фактора некроза опухолей альфа (ФНО- $\alpha$ ), фактора роста эндотелия сосудов (VEGF) и интерферона- $\gamma$ (ИНФ- $\gamma)$ ) в сыворотке крови обследуемых лиц проводили методом ИФА с использованием соответствующих наборов реагентов (ЗАО «Вектор-Бест», Новосибирск).

Оценку экспрессии кластеров $\mathrm{CD}^{+} \mathrm{HLA}^{-\mathrm{DR}}{ }^{+}-$маркера поздней активации лимфоцитов, $\mathrm{CD}^{+} \mathrm{CD}^{+}-\mathrm{T}$-хелперов, $\mathrm{CD} 3{ }^{+} \mathrm{CD} 4^{+} \mathrm{CD} 25^{+}-$активированных $\mathrm{T}$ хелперов, $\mathrm{CD} 3^{+} \mathrm{CD} 4^{+} \mathrm{CD} 25^{+} \mathrm{CD} 127^{-}$регуляторных Т-лимфоцитов, $\mathrm{CD} 3{ }^{+} \mathrm{CD} 4^{+} \mathrm{CD} 28^{+}-$костимулирующих молекул проводили методом проточной цитофлюориметрии с использованием соответствующих моноклональных антител и красителей FITC, PE, PC5, PC7 («Beckman Coulter», США).

Результаты. У пациентов с циррозом печени на фоне вирусов гепатита В или C (группа I) содержание В-лимфоцитов, экспрессирующих кластер дифференцировки CD22+, был снижен $(8,0 \pm 2,0) \%$, при этом в группах II и III уровень CD22+ В-лимфоцитов был повышенным: соответственно $(19,8 \pm 2,2)$ и $(15,2 \pm 4,0)$ относительно референтных значений - $(9,0 \pm 4,5) \%$.

Концентрация IgA в сыворотке крови пациентов группы I была достоверно повышена и составила $(4,12 \pm 3,5)$ г/л при референтных значениях $(1,9 \pm 0,9)$ г/л. В группе II также выявили повышение IgA на 45\%, что составило 2,76士1,6 г/л. 
Выявили повышенное содержание $\operatorname{IgM}$ - на 53\% в группе I, что составило $(1,84 \pm 0,81)$ г/л, и на $91 \%$ - в группе II, что соответствовало показателю $(2,3 \pm 0,7)$ г/л при референтном значении $(1,2 \pm 0,35)$ г/л. В группе III концентрация IgA и $\operatorname{IgM}$ не отличалась от референтных значений. Содержание IgG в группах I и II было несколько выше $((14,8 \pm 1,7)$ г/л и $(14,3 \pm 3,2)$ г/л соответственно), чем в группе III $(11,8 \pm 3,1)$ г/л, но достоверно не отличалось от контроля $(11,55 \pm 3,9)$ г/л.

$\mathrm{y}$ пациентов с гепатоспленомегалией выявили снижение уровня

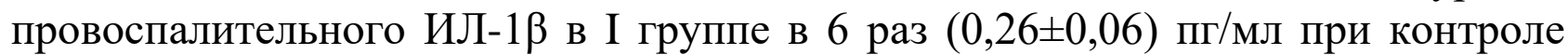
$(1,6 \pm 0,2)$ пг/мл и 3 -кратное повышение концентрации данного цитокина в группе II - $(4,35 \pm 0,21)$ пг/мл. Содержание ИЛ-2 и ИЛ-6 было повышенным во всех исследуемых группах. ИФН- $\gamma$ был достоверно высоким у пациентов гепатоспленомегалией на фоне герпесвирусных инфекций (II группа) и превышал референтные значения на 75 \%, тогда как в I и III группах данный показатель достоверно не отличался от контроля. ФНО-а был повышен у пациентов I и II групп в 4 и 10 раз соответственно, тогда как в группе III данный цитокин был значительно ниже референтных значений.

Выявили высокую концентрацию противовоспалительных цитокинов ИЛ-4 и ИЛ-10 в I группе $(1,23 \pm 0,2)$ пг/мл при референтном значении $(0,2 \pm 0,01)$ мг/мл и концентрацию ИЛ-10 во всех обследованных группах, но максимальное его значение (повышение в 7 раз) выявили так же в группе I - $(27,8 \pm 2,3)$ пг/мл при контроле 4,5 1,1 пг/мл.

Для формирования адекватного иммунного ответа на антиген с его последующей элиминацией из организма важна активация лимфоцитов популяции $\mathrm{T}$-хелперов $\mathrm{CD} 3^{+} \mathrm{CD} 4^{+}$. Количество активированных $\mathrm{T}$-клеток с фенотипом $\mathrm{CD}^{+} \mathrm{CD}^{+} \mathrm{CD} 25^{+}$у пациентов с гепатоспленомегалией I и II группы было сниженным до значения $(1,5 \pm 0,25) \%$ и $(2,6 \pm 0,75) \%$ соответственно при контроле $(3,5 \pm 0,5) \%$, а в группе III выявили увеличение количества активированных Т-хелперов в 1,2 раза.

В I и II группах пациентов выявили снижение количества регуляторных Tregклеток CD3+CD4+CD25+CD127- продуцентов ИЛ-10 до значения $(1,9 \pm 0,1) \%$ и $(2,3 \pm 0,2) \%$ соответственно при контроле $(4,5 \pm 1,5) \%$.

Экспрессия костимулирующих молекул CD3+CD4+CD28+ была снижена в I группе (HCV/HBV) на 46\%, в группе II (CMV/VEB) - на 34\%. Наиболее выраженным снижение (в 2 раза) выявили в группе III пациентов с гепатоспленомегалией на фоне врожденных ферментопатий.

При исследовании экспрессии HLA-DR II класса на T-клетках - рецептора, участвующего в трансдукции сигнала активированными Т-лимфоцитами, выявили разнонаправленные изменения - в группе I увеличение экспрессии маркера поздней активации лимфоцитов CD3+HLA-DR+ в среднем на $63 \%$, у пациентов группы II и III выявили снижение экспрессии CD3+HLA-DR+ на 56\% и $45 \%$ соответственно. гепатоспленомегалии выявили различные механизмы иммунологической 
дисрегуляции продукции цитокинов, иммуноглобулинов на фоне изменения экспрессии кластеров дифференцировки СD Т- и В-лимфоцитов.

2. $\mathrm{У}$ пациентов группы I с гепатоспленомегалией вирусной $\mathrm{HBV} / \mathrm{HCV}$ этиологии на фоне сниженного содержания CD22+-B-лимфоцитов выявили двукратное увеличение концентрации $\operatorname{IgA}$; высокую концентрацию противовоспалительных цитокинов ИЛ-4 и ИЛ-10 и снижение их продуцентов регуляторных Т-лимфоцитов $\mathrm{CD} 3{ }^{+} \mathrm{CD} 4{ }^{+} \mathrm{CD} 25^{+} \mathrm{CD} 127^{-}$.

3. У пациентов группы II с гепатоспленомегалией вирусной CMV/VEB этиологии выявили гуморальную сенсибилизацию Th2-зависимого антителообразования, что характеризовалось повышенным содержанием IgM и их продуцентов - CD22+-В-лимфоцитов; сниженной супрессорной активностью $\mathrm{CD} 8+-\mathrm{T}$-лимфоцитов, высоким содержанием провоспалительных цитокинов ИЛ$1 \beta$, ФНО- $\alpha$, что свидетельствует о хроническом воспалительном процессе с формированием аутоиммунного компонента.

4. У пациентов группы III c генетически детерминированной гепатоспленомегалией на фоне нормального содержания сывороточных иммуноглобулинов IgA, IgM, IgG выявили повышение экспрессии CD22+-Bлимфоцитов, сниженное содержание провоспалительного ФНО- $\alpha$, повышенный уровень ИЛ-6 и фактора роста сосудов VEGF.

5. Выявленные в исследуемых группах пациентов особенности иммунореактивности свидетельствуют о различных механизмах формирования гепатоспленомегалии, зависящих от триггерных факторов, что должно учитываться при выборе направленной персонифицированной иммунокоррегирующей терапии в комплексном консервативном лечении пациентов с гепатоспеномегалией.

\section{Список литературы}

1. Mebius R.E. Structure and function of the spleen / R.E. Mebius, G. Kraal // Nat Rev Immunol. - 2005. - V5(8). -P. 606-616.

2. Михеева О.М., Ли Е.Д., Селеванова Г.Б., Кузнецов О.О., Ефремов Л.И. Цирроз печени // Клиническая геронтология. 2010. № 1-2. С. 39 - 47.

3. Петров В.Н., Лапотников В.А. Цирроз печени // Российский семейный врач. 2011. С. 46-51. 


\section{ПЕРЕБІГ ВАГІТНОСТІ НА ФОНІ РОЗСІЯНОГО СКЛЕРОЗУ (ОГЛЯД ЛІТЕРАТУРИ)}

Курташ Наталія Ярославівна,

К.мед.н., доцент кафедри акушерства та гінекології ім.І.Д. Ланового Івано-Франківського національного медичного університету

Кравчук Інна Валеріївна

К.мед.н., доцент кафедри акушерства та гінекології ім.І.Д. Ланового Івано-Франківського національного медичного університету

Ласитчук Оксана Миколаївна

К.мед.н., доцент кафедри акушерства та гінекології ім.І.Д. Ланового Івано-Франківського національного медичного університету

Розсіяний склероз (РС) - це аутоімунне захворювання, яке переважно вражає жінок дітородного віку, що може свідчити про потенційний вплив статевих гормонів на нервову, ендокринну та імунну системи .

Відомо, що РС частіше зустрічається серед жінок і на нього впливають гормональні зміни, які жінки відчувають протягом життя[1,2].

Метою нашого дослідження був огляд літературних джерел останніх десяти років щодо виявлення кореляції між впливом вагітності та гормональних факторів на розвиток та перебіг РС. Розглянемо результати, що стосуються етіології, патофізіології захворювання на експериментальних моделях, узагальнимо результати клінічних випробувань, а також наслідки для управління прогресуванням захворювання та ризиком для плода. Узагальнимо набір рекомендацій щодо лікування РС у жінок дітородного віку та у вагітних.

Матеріали та методи. Було проведено всебічний огляд наукових публікацій у базі даних PubMed, використовуючи пошук за ключовими словами для «розсіяного склерозу», «ЕАЕ» «вагітності», «гормональних факторів», «лікування» та пов'язаних термінів. Ми розглянули досягнення, представлені на засіданні Свропейського комітету з лікування та досліджень розсіяного склерозу (ECTRIMS), а також рекомендації міжнародних експертів.

\section{Результати дослідження.}

Розсіяним склерозом переважно страждають жінки (70\%); 90\% жінок з РС відчувають перші симптоми до 50 років, i, за оцінками, 20\% -33\% цих жінок матимуть дітей після діагностики. Недавні епідеміологічні дослідження повідомляють про збільшення захворюваності на РС у дорослих жінок, що призводить до збільшення співвідношення жінок та чоловіків із 2: 1 до 3: 1 за останні 30 років. Згідно з датським реєстром, захворюваність на РС серед жінок подвоїлася з 1990 р. [2,3]. 
Той факт, що співвідношення жінок і чоловіків зросло в багатьох областях, але різними темпами [2,3] може свідчити про те, що розвиток хвороби включає епігенетичні фактори, тобто взаємодію між генами та такими іншими факторами, як навколишнє середовище, [3] змін у способі життя (контрацепція, дієта, ожиріння, куріння, вплив сонячного світла, дефіцит вітаміну D) [4], старший вік при народженні першої дитини, молодшого віку настання менархе або менше вагітностей протягом життя жінки [5].

Кілька досліджень, як на тваринних моделях експериментального алергічного енцефаломієліту (ЕАЕ), так і на людях показали вплив статевих гормонів на експресію захворювання, прогноз та активність. Такі висновки мають значення для вагітності та для розробки методів лікування PC. Дослідження на тваринних моделях ЕАЕ показали, що естрогени, зокрема $17 \beta$-естрадіол $\quad(\mathrm{E} 2) \quad$ та естріол $\quad(\mathrm{E} 3)$, прогестерон та тестостерон мають протизапальну та нейропротекторну дію, як на індукторній, так і на ефекторній стадіях перебігу захворювання [6,7]. Ці протизапальні ефекти опосередковані рецепторами естрогену альфа (ER- $\alpha)$ та бета (ER- $\beta)$, які рівноправно експресуються в $\mathrm{CD}^{+} \quad \mathrm{CD} 25^{+}$регуляторних $\mathrm{T}$ клітинах , регуляторних В-клітин, і дендритних клітин. Важливість В-клітин для індукованого Е2 захисту демонструється тим фактом, що захисний ефект зникає при елімінації В-клітин [7,8]. Захисні ефекти Е2 в ЕАЕ також залежать від, так званого, рецептора 30, що пов'язаний 3 G-білком (GPR30) [9]. Тестостерон може діяти через андрогенні рецептори або після того, як він перетворюється в естрогени за допомогою ER або GPR30 . Експериментальні дослідження показали, що андрогени можуть викликати в центральній нервовій системи (ЦНС) процеси ремієлінізації після cuprizone-індукованої демієлінізації [10].

Деякі нейропротекторні ефекти естрогенів в EAE опосередковуються ER- $\alpha$, експресованим в астроцитах, а дія лігандів ER- $\beta$ може запобігти демієлінізації та стимулювати ремієлінізацію; лікування лігандами ER- $\beta$ може мати захисний ефект на мікроглію, запобігаючи запаленню ЦНС. Прогестерон бере участь у захисті аксонів і ремієлінізація, тоді як тестостерон може відновити синаптичну передачу в гіпокампі[11].

Жінки, які планують зачаття, стикаються з численними занепокоєннями, включаючи вплив РС на фертильність, ризик передачі РС нащадкам, вплив ліків від РС на плід, вплив вагітності на прогресування захворювання , вплив РС на стан матері здатність доглядати за своєю дитиною та соціально-економічне навантаження на сім'ю[10,12,13].

За рекомендаціями FDA (США) слід уникати прийому кортистероїдів протягом I триместру через розвиток вад розвитку плода, зокрема розщеплення піднебіння. Високі дози метилпреднізолону відносно безпечні для лікування рецидивів РС протягом II-III триместрів, тому рекомендується знизити дози через можливість розвитку легкого лейкоцитозу та імунодепресію у новонароджених[14]. 
Лікування РС під час вагітності повинно бути адаптоване до потреб кожного паціснта 3 урахуванням таких змінних, як вік, прогресування захворювання, клінічна та рентгенологічна стабільність, попередні рецидиви, інвалідність, ризики припинення лікування, ризики збереження лікування та переваги пацієнта[15,16].

У виняткових випадках вагітним жінкам продовжується модифікована терапія, враховуючи співвідношення користь/ризик і індивідуальним підбором препарату і дози[17].

У експериментальних тварин, які отримували більші дози IFN- $\beta$, ніж люди, абортивні ефекти препарату посилювались залежно від дози протягом I триместру, тож препарат слід припинити негайно після встановлення факту вагітності. Два дослідження, що аналізують невелику кількість пацієнтів з РС, які завагітніли під час прийому IFN- $\beta-1 \mathrm{a}$ та IFN- $\beta-1 \mathrm{~b}$ повідомляють про більшу, ніж очікувалося, частоту викиднів. Однак подальші дослідження з більшими зразками не змогли підтвердити ці результати[6]. Ці дослідження повідомляють про низьку частоту вад розвитку плода (аналогічні показникам серед загальної популяції). Однак недостатньо даних, щоб виключити зв'язок між лікуванням IFN- $\beta$ та рідкісними патологіями плода $[18,19]$.

Деякі із серії вагітних жінок, які отримували IFN- $\beta$, демонструють незначне збільшення кількості передчасних пологів та гіпотрофію плоду. Ці висновки не підтверджені результатами інших серій[20].

Глатирамер ацетат FDA класифікує, як і попередній препарат, як такий, що має негативний вплив при вагітності. Проте його профіль безпеки є більш сприятливим, оскільки жодних змін, пов'язаних із застосуванням препарату, не спостерігалося на моделях тварин. Молекула не може проходити через плаценту або виводитися в грудне молоко через високу молекулярну масу. Дослідження вагітних жінок, які отримували глатирамер ацетат, у тому числі понад 400 пацієнтів, показали безпеку препарату та повідомили про відсутність вад розвитку плода $[14,16]$. Однак, враховуючи малу кількість вагітних жінок, які отримували препарат, не можна виключати ризик вад розвитку плода, тому цей препарат слід застосовувати з обережністю.

Наталізумаб ліки з категорії ризику під час вагітності. Препарат асоціюється iз збільшенням частоти викиднів у тварин. Пацієнтам слід припинити застосування наталізумабу мінімум за з місяці до початку планування вагітності через виявлені гематологічні зміни (тромбоцитопенія та гемолітична анемія у 8 3 кожних 9 живонароджених)[18].

Терифлуномід та фінголімод $є$ препаратами з вираженим тератогенним ефектом на моделях тварин, тому протипоказані під час вагітності [15] .

Диметилфумарат токсичний для плода та викликає проблеми з яєчками, низьку масу тіла при народженні та поведінкові зміни у експериментальних тварин[16].

Мітоксантрон слід припинити під час вагітності через його потенційну тератогенність. Препарат також може спричинити безпліддя, передчасну недостатність яєчників та аменорею, особливо у жінок старше 35 років [10]. 
Наявної інформації щодо симптоматичного лікування РС недостатньо для надання обгрунтованих доказів щодо використання цих препаратів під час вагітності, за винятком протиепілептичних препаратів. Баклофен, оксибутинін, амантадин і клоназепам, симптоматичні препарати, які часто використовуються при РС, класифікуються за категоріями ризику вагітності $\mathrm{B}, \quad \mathrm{C}$ або $\mathrm{D}$. Загалом рекомендується припинення симптоматичного лікування до зачаття[20].

Клінічне дослідження перорального естріолу, що включало 10 жінок із рецидивуючо-ремітуючою РС, показало поліпшення уражень, що посилюють гадоліній на МРТ. Результати цих досліджень вказують на нейропротекторну та імуномодулюючу дію естрогенів у жінок. [21].

Вплив оральних контрацептивів на запалення також оцінювали за допомогою МРТ. Одне дослідження включало 149 жінок, які отримували підшкірний IFN- $\beta$-1a, яким випадковим чином було призначено отримувати або IFN- $\beta-1 \mathrm{a}$, IFN- $\beta-1$ а плюс 20 мкг етинілестрадіолу та 150 мкг дезогестрелу (група 3 низькими дозами естрогену), або IFN- $\beta$-1а плюс 40 мкг етинілестрадіолу та 125 мкг дезогестрелу (група 3 високими дозами естрогену) [19]. Група, яка отримувала високі дози естрогенів, продемонструвала зменшення кількості нових уражень протягом 2-річного періоду спостереження. Ці результати вказують на те, що оральні контрацептиви, що містять високі дози естрогенів, можуть посилити вплив IFN- $\beta[19,21]$. Епідеміологічні дані показали, що естрогенвмісні оральні контрацептиви не збільшують ризик розвитку PC; швидше, вони затримують початок захворювання. Ще одне дослідження лікування прогестероном та естріолом при PC протягом післяпологового ефективність терапії статевими гормонами , періоду проаналізувало 10 мг номегестролацетату та плацебо протягом 12 тижнів, і не виявило різниці між групами частоти рецидивів протягом післяпологового періоду[22].

Висновки. Епідеміологічні зміни захворюваності на РС вимагають подальших досліджень; нові клінічні дані можуть призвести до нових стратегій профілактики та лікування РС. Однак результати не завжди є послідовними і часом суперечливі. Це може відображати методологічні проблеми, такі як невеликі вибірки, неоднорідні популяції та незрозумілі фактори (супутні захворювання, спільне лікування, сімейний анамнез та вік матері). Майбутні дослідження повинні розглянути наслідки вагітності та лікування РС під час вагітності на перебіг захворювання, використовуючи реєстри пацієнтів, отримані $з$ незалежних національних баз даних, та проаналізувати довгостроковий вплив на матерів та їх дітей. Одне з питань реєстрацій державчленів полягає у складності поєднання наборів даних для створення великих міжнародних когорт зі спільною демографічною та клінічною інформацією.

Подальші дослідження необхідні для визначення механізмів дії та потенційних позитивних та негативних наслідків різних фармакологічних методів лікування захворювання. 


\section{Список літератури:}

1. Evaluation of reproductive health in female patients with multiple sclerosis in Polish population/Journal of Clinical Neuroscience, Volume 53, 2018, pp. 117-121

2. R.R. Voskuhl, S.M. Gold/Sex-related factors in multiple sclerosis susceptibility and progression//Nat Rev Neurol, 8 (2012), pp. 255-263

3. J. Sellner, J. Kraus, A. Awad, R. Milo, B. Hemmer, O. Stüve/The increasing incidence and prevalence of female multiple sclerosis - a critical analysis of potential environmental factors//Autoimmun Rev, 10 (2011), pp. 495-502

4. F. Mirzaei, K.B. Michels, K. Munger, E. O’Reilly, T. Chitnis, M.R. Forman, et al./Gestational vitamin $\mathrm{D}$ and the risk of multiple sclerosis in offspring//Ann Neurol, 70 (2011), pp. 30-40

5. P.A. McCombe, J.M. Greer/Female reproductive issues in multiple sclerosis//Mult Scler, 19 (2012), pp. 392-402

6. D. Baker, W. Gerritsen, J. Rundle, S. Amor/Critical appraisal of animal models of multiple sclerosis//Mult Scler, 17 (2011), pp. 647-657

7. S. Bodhankar, C. Wang, A. Vandenbark, H. Offner/Estrogen-induced protection against experimental autoimmune encephalomyelitis is abrogated in the absence of B cells//Eur J Immunol, 41 (2011), pp. 1165-1175

8. S. Bodhankar, A.A. Vandenbark, H. Offner/Oestrogen

treatment of experimental autoimmune encephalomyelitis requires $17 \mathrm{p}$-oestradiol-receptor-positive $\mathrm{B}$ cells that up-regulate PD-1 on CD4+ Foxp3+ regulatory $\mathrm{T}$ cells.//Immunology, 137 (2012), pp. 282-293

9. S. Bodhankar, H. Offner/ GPR30 forms an integral part of E2-protective pathway in experimental autoimmune encephalomyeliti// Immunol Endocr Metab Agents Med Chem, 11 (2011), pp. 262-274

10.

D.H. Miller, F. Fazekas, X. Montalban, S.C. Reingold, M. Trojano/Pregnancy, sex and hormonal factors in multiple sclerosis//Mult Scler J, 20 (2014), pp. 527-536

11.

R. Hussain, M. E/Etr, O. Gaci, J. Rakotomamonjy, W.B. Macklin, N. Kumar, $e$ $t$ al./Progesterone and nestorone facilitate axon remyelination: a role for progesterone receptors//Endocrinology, 152 (2011), pp. 3820-3831

12. R.D. Spence, M.E. Hamby, E. Umeda, N. Itoh, S. Du, A.J. Wisdom, et al./Neuroprotection mediated through estrogen receptor-alpha in astrocytes//Proc Natl Acad Sci U S A, 108 (2011), pp. 8867-8872

13. Masoud Ghiasiana Mohaddeseh, NouriaAbdorreza Naser Moghadasib, Mehran Ghaffaric/ Effect of pregnancy and exclusive breastfeeding on multiple sclerosis relapse rate and degree of disability within two years after delivery/Clinical Neurology and Neurosurgery, Volume 194, 2020, Article 105829

14. B.A. Cree/Update on reproductive safety of current and emerging diseasemodifying therapies for multiple sclerosis//Mult Scler, 19 (2013), pp. 835-843

15. M.K. Houtchens, C.M. Kolb/Multiple sclerosis and pregnancy: therapeutic considerations//J Neurol, 260 (2013), pp. 1202-1214 
16. K. Hellwig, A. Haghikia, M. Rockhoff, R. Gold/Multiple sclerosis and pregnancy: experience from a nationwide database in Germany//Ther Adv Neurol Disord, 5 (2012), pp. 247-253

17.

P.I. Wang, S.T. Chong, A.Z. Kielar, A.M. Kelly, U.D. Knoepp, M.B. Mazza, M.M.Goodsitt/Imaging of pregnant and lactating patients: Part 1 - Evidence-based review and recommendations//Am J Roentgenol, 198 (2012), pp. 778-784

18.

A.L. Ponsonby, R.M. Lucas, I.A. vanderMei, K. Dear, P.C. Valery, M.P. Pende $\mathrm{r}$, et al./Offspring number, pregnancy, and risk of a first clinical demyelinating event: the Auslmmune Study//Neurology, 78 (2012), pp. 867-874

19. S. Tomczyk, B. Sperling/Pregnancy outcomes in patients exposed to intramuscular interferon beta-1a (IM IFNB 1a)//Neurology, 80 (Meeting Abstracts 1) (2013)

20.

S. Ramagopalan, I. Yee, J. Byrnes, C. Guimond, G. Ebers, D. Sadovnick/Term pregnancies and the clinical characteristics of multiple sclerosis: a population based study//J Neurol Neurosurg Psychiatry, 83 (2012), pp. 793-795

21.

E. Lu, B.W. Wang, C. Guimond, A. Synnes, D. Sadovnick, H. Tremlett/Diseas e-modifying drugs for multiple sclerosis in pregnancy: a systematic review//Neurology, 79 (2012), pp. 1130-1135

22. S. Vukusic, M. El-Etr, I. Ionescu, F. Cotton, H. Merle, C. Cornu, et al./The POPARTMUS French-Italian multicentric trial of post-partum progestin and estriol in multiple sclerosis: final results//Mult Scler, 18 (S4) (2012), p. 45

23. Evaluation of reproductive health in female patients with multiple sclerosis in Polish population/Journal of Clinical Neuroscience, Volume 53, 2018, pp. $117-121$ 


\title{
МЕТАБОЛІЧНІ ТА ГЕМАТОЛОГІЧНІ РОЗЛАДИ У ХВОРИХ НА РАК ГРУДНОЇ ЗАЛОЗИ
}

\author{
Сорочан Павло Павлович \\ канд.мед.наук, завідувач лабораторії радиаційної імунології, \\ Державна установа «Інститут медичної радіології та \\ онкології ім. С. П. Григор'єва Національної академії \\ медичних наук України», Харків, Україна
}

\section{Кузьменко Олена Вікторівна}

канд.біол.наук, старший науковий співробітник, Державна установа «Інститут медичної радіології та онкології ім. С. П. Григор'єва Національної академії медичних наук України», Харків, Україна

Прохач H.E.

канд.мед. наук,старший науковий співробітник, Державна установа «Інститут медичної радіології та онкології ім. С. П. Григор'єва Національної академії медичних наук України», Харків, Україна

Рак грудної залози (РГЗ) входить до найрозповсюдженіших форм злоякісних новоутворень серед жіночого населення України. У значної частини онкологічних хворих виявляють метаболічні розлади, які, як відомо, пов’язані 3 підвищеним ризиком розвитку та прогресування онкологічного процесу. Реакції організму хворих з метаболічними розладами на проведення протипухлинного лікування та перебіг онкологічного захворювання $\epsilon$ менш вивченими. $€$ підстави вважати, що негативні ефекти метаболічних розладів щодо ускладнень та результатів протипухлинного лікування можуть бути спричинені як безпосередньо метаболічними розладами, так і 3 тісно пов'язаними 3 ними гематологічними порушеннями.

Метою дослідження було визначення особливостей метаболічних та гематологічних розладів після променевого лікування хворих на рак грудної залози (РГЗ).

Матеріали та методи. Клініко-лабораторне обстеження проведено 45 хворим на РГЗ I-II стадій $\left(\mathrm{T}_{1} \mathrm{~N}_{0} \mathrm{M}_{0}-\mathrm{T}_{2} \mathrm{~N}_{0} \mathrm{M}_{0}\right)$. Переважали жінки віком від 51 до 60 років. Усім хворим було проведено післяопераційний курс дистанційної гамма-терапії на лінійному прискорювачі «Clinac 600C» методом дробного фракціонування. Сумарна осередкова доза складала 40-45 Гр. Обстеження проводили до лікування та після курсу дистанційної гамма-терапії.

Для проведення гематологічних досліджень венозну кров збирали в антикоагулянт ЕДТА у відношенні 9:1. Аналіз проводили на автоматичному гематологічному аналізаторі Sysmex XN-L 550 (Японія).

Для дослідження рівня інсуліну в сироватці крові визначали за допомогою 
набору реагентів для імуноферментного визначення «DRG Insulin ELISA (EIA2935)» (Німеччина, «DRG Instruments $\mathrm{GmbH»).} \mathrm{Індекс} \mathrm{інсулінорезистентності}$ (IP) (індекс НОМА) розраховували за формулою: $\mathrm{HOMA}=\frac{a \cdot b}{22,5}$,

де $a$-глюкоза крові натще, ммоль/л;

$b$ - інсулін крові натще, мкМО/мл; НОМА, ум. од.

Індекс НОМА більш ніж 2,77 ум. од. розцінювали як наявність інсулінорезистентності.

Рівень лептину визначали за допомогою набору реагентів для імуноферментного аналізу «Leptin Sandwich Elisa» (Німеччина, «DRG

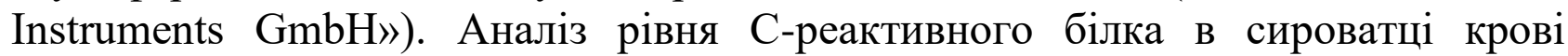
проводили на автоматичному біохімічному аналізаторі «RESPONS 910» (Німеччина). Рівнь ІЛ-6 в сироватці крові визначали за допомогою набора реагентів для імуноферментного визначення «ИФА-ИЛ-6» (Росія, ООО «Цитокин»). Статистична обробка даних здійснювалася за допомогою пакета статистичного аналізу STATISTICA 6.0.

\section{Результати та їх обговорення}

Онкологічним хворим було проведено антропометричне обстеження і на підставі отриманих даних розраховано індекс маси тіла. За IMT хворі були розділені на групи. Хворі з нормальною вагою (індекс ваги тіла від 20,0 до 24,9 кг $/ \mathrm{M}^{2}$ ) склали контрольну групу (К); хворі з ожирінням I ступеня (IMT $=30,0$ $34,9)$ - I групу, хворі з ожирінням II (IMT = 35,0-39,9) та III (IMT > 40) ступеня, відповідно, II та III групу

У більшості хворих на РГЗ наявні метаболічні розлади: збільшений індекс маси тіла (IMT) виявлено у $67 \%$ хворих. Підвищений вміст холестерину спостерігали у $73 \%$ хворих на РГЗ, інсулінорезистентність зареєстровано у $65 \%$ хворих. Доведено високу предиктивну значущість вихідного розподілу пацієнток до початку лікування. За наявності високого рівня С-реактивного білка та ІЛ-6 після протипухлинного лікування виявлено у хвороих з ожирінням III ступеня. У III групі хворих на РГЗ відмічене більш високу у порівнянні з К та I, II групами кількість нейтрофілів та еозинофілів. Доведено виражене зниження абсолютної кількості лімфоцитів у даних хворих з III ступенем ожиріння після променевого лікування. Абсолютна кількість лімфоцитів зменшувалась в 2,6 раза у хворих контрольної групи, у 3 рази у хворих із I та II ступенем ожиріння та в 3,4 раза у хворих 3 III ступенем ожиріння. Встановлено позитивний кореляційний зв'язок абсолютної кількості лімфоцитів 3 рівнем інсуліну та негативні кореляційні зв'язки з рівнями ІЛ- 6 та С-реактивного білка.

Значно вищі рівні лептина реєстрували у хворих з ожирінням (I-III групи). У хворих на РГЗ кореляційний аналіз виявив позитивний зв'язок рівня гормону з індексом маси тіла $(\mathrm{R}=0,963 ; \mathrm{p}=0,00000001)$. Дослідження останніх років припускають роль лептина/дисрегуляції рецептора лептина у розвитку онкологічних захворювань, включаючи рак грудної залози, головним чином через JAK/STAT сигнальний шлях, який модулює, ERK1/2 сигнальну передачу, експресію антиапоптотичних білків (таких як XIAP), системне запалення (ФНП$\alpha$, IL6) та експресію ангіогенних факторів та гіпоксія-індуцибельного фактора- 
$1 \alpha[1,2]$. Повідомляють також про залучення гормону до розвитку резистентності до хіміотерапевтичного лікування [3].

Отже у хворих з вираженими метаболічними порушеннями, відбуваються системні зміни, які можуть сприяти розвитку та прогресуванню онкологічного захворювання, а також розвитку резистентності до протипухлинного лікування.

\section{Список літератури}

1. Deep D., Sujoy G., Kaushik P., Pradip M., Subhankar C. Leptin and cancer: Pathogenesis and modulation. (2012). Indian J. Endocrinol. Metab.Dec;16(Suppl 3):S596-600. https://doi.org/ 10.4103/2230-8210.105577.

2. Saxena N. K., Sharma D. Multifaceted leptin network: the molecular connection between obesity and breast cancer. (2013). J. Mammary Gland Biol. Neoplasia. Dec; 18(3-4):309-20. https://doi.org/ 10.1007/s10911-013-9308-2.

3. Candelaria P. V., Rampoldi A., Harbuzariu A., Gonzalez-Perez R. R. (2017). Leptin signaling and cancer chemoresistance: Perspectives. World J. Clin. Oncol. Apr 10; 8(2):106-119. https://doi.org/ 10.5306/wjco.v8.i2.106. 


\title{
ОСОБЛИВОСТІ ЗАСТОСУВАННЯ ТРАНСКРАНІАЛЬНОЇ МІКРОПОЛЯРИЗАЦЇ̈ ГОЛОВНОГО МОЗКУ В ПРОГРАМІ РЕАБІЛІТАЦЇ̈
}

\author{
Ульяницька Н. Я. \\ кандидат біологічних наук, \\ доцент кафедри фізичної терапії та ерготерапії \\ Волинського національного університету \\ імені Лесі Українки

\section{Ребрик Юлія Юріївна} \\ аспірант кафедри фізичної \\ терапії та ерготерапії \\ Волинського Національного університету \\ імені Лесі Українки.
}

В останні роки відбулося широке впровадження новітніх методів відновлення організму людини, які використовують у різних сферах медицини. До таких методів належить - мікрополяризація мозку, що дає можливість цілеспрямованої терапії при різноманітних неврологічних патологіях.[1] . Транскраніальна мікрополяризація, при проєкційному впливі на зони головного мозку, сприяє активації зон мовлення, дій, пам'яті, апарату мовлення, зміцнює зв'язки в тканинах нервової системи і покращує роботу 1 й 2 сигнальних систем мозку, через які відбувається сприйняття й обробка всіх сигналів ззовні та формування осмислених дій у відповідь на отриманий сигнал. Прямими показаннями до мікрополяризації є патології ЦНС, реабілітація після черепно-мозкових травм. .[2]

Даний метод терапії може бути використаний щодо пацієнтів 3 різними патологіями нервової системи, такими як черепно-мозкові травми та їх ускладнення, епілепсія (терапія проводиться не у всіх центрах, оскільки ведуться суперечки $з$ приводу доцільності такої терапії при епілепсії), дитячий церебральний параліч (ДЦП), мовні патології у пацієнтів дитячого віку, головні болі та мігрені, затримка психо-неврологічного розвитку у дітей та стани пов'язані з даними порушеннями ( синдром дефіциту уваги і гіперактивності (СДУГ), мовні патології у пацієнтів дитячого віку), органічні ураження ЦНС, нейроінфекції, трансформації головного мозку в зв'язку з віком, а також психоемоційні захворювання, депресії та інші.[3]

Транскраніальна мікрополяризація $є$ одним 3 найбільш безпечних i результативних методів лікування порушень метаболічних процесів в головному мозку. Метод транскраніальної мікрополяризації дає можливість прискорити уповільнений розвиток функціональності ЦНС.[4]

Основним позитивним аспектом транскраніальної електростимуляції є те, що вона безболісна і неінвазивна. Це унікальна процедура в тому сенсі, що вона діє безпосередньо на функцію нейронів, на відміну від фармакологічних 
втручань, які повинні виконувати ряд кроків до досягнення мозку, без необхідності відкривати або вводити що-небудь. Це відкриває цілий спектр терапевтичних можливостей, які не можна використовувати традиційними методами. .[5]

Методика проведення терапії транскраніальної мікрополярізації головного мозку (ТКМП) або Transcranial Direct Current Stimulation - це безперервна дія на деякі структури головного мозку за допомогою електричного струму невеликої сили. Дія преформованих чинників така: через пару електродів, розміщених на черепі, дуже слабкий електричний струм подається безпосередньо на мозок протягом декількох хвилин. При цих струмах генерується електричне поле, яке модулює нейрональну активність. Як відомо, активація чи ні нейронів пов'язана 3 їх деполяризацією, електричним процесом, який можна модифікувати. Крім того, тип струму, який використовується в стимуляції, матиме особливі ефекти. Наприклад, відомо, що за допомогою транскраніальної електростимуляції постійними струмами нейрони змінюють швидкість їх розряду. Залежно від того, чи $є$ вона катодним або анодним, ефекти призводять до збільшення або зменшення в ньому. Ці зміни можуть тривати від хвилин до годин після стимуляції, в залежності від параметрів одного і того ж. Безперечно, що стимуляція за допомогою постійного струму здатна змінити працездатність індивідів у широкому спектрі когнітивних завдань.

Транскраніальна мікрополяризація передбачає розміщення електродів на проєкціях таких зон головного й спинного мозку як:

- $\quad$ коркова (електроди розміщуються в проєкції зон головного мозку);

- сегментарна (електроди розміщуються в проєкції зон спинного мозку).

Таким чином, транскраніальная мікрополярізація може бути використана в якості допоміжної терапії різних патологій у дітей і дорослих пацієнтів, а також застосовується як самостійний терапевтичний метод.

\section{Список літератури}

1. Основи фізичної реабілітації : [навч. посіб. для студ. вищ. мед. навч. закл. IIII рівнів акредитації] / А. М. Порада, О. В. Солодовник, Н. С. Прокопчук. Вид. 2-ге. - К. : Медицина, 2008. — 246 с. : іл., табл. ; 21 см. - Бібліогр.: с. $240-241$.

2. Сікорська М.В. Досвід застосування мікрополяризації в лікуванні хворих з неврологічними захворюваннями / Ременюк Ю.К., Душенко В,В, Мархін В.Г. // Міжнародний неврологічний журнал. - 2016. - № 3(81). - С. 159-162.

3. Яценко Е. В. Микрополяризация - эффективный неинвазивный метод нейростимуляции при органических поражениях головного мозга у детей / Е. В. Яценко // Art of medicine. - 2019. - № 2. - С. 123-127. - Режим доступу: http://nbuv.gov.ua/UJRN/artmed_2019_2_20.

4. Вадзюк С.Н. Порушення зорових функцій у підлітків 3 еметропічною рефракцією при візуальному комп’ютерному навантаженні та їх відновлення/ С.Н. Вадзюк Н.Я. Ульяницька, Н.О. Бєлікова, С.Я. Індика, Ю.С. Вадзюк, М.О. Сопіга/ Фізіологічний журнал 2018, Т. 64, № 5. С - 47-53 
5. Canadian Hypertension Education Program recommendations for the management of hypertension: blood pressure measurement, diagnosis, assessment of risk, and therapy. Can J Cardiol. Jul-Aug 2011;27(4):415-433.e1-2. 


\title{
METHODOLOGY OF IMPROVING EFFICIENCY OF SPATIAL AWARENESS FORMATION OF HIGER EDUCATION APPLICANTS DURING THE BASIC COURSE
}

\author{
Artemenko Dmytro \\ $\mathrm{PhD}$ of Technical Sciences, Associate Professor \\ Central Ukrainian National Technical University \\ Kropyvnytskyi, Ukraine
}

Artemenko Olga

$\mathrm{PhD}$ of Technical Sciences, Associate Professor Flight Academy of National Aviation University Kropyvnytskyi, Ukraine

Introduction. Nowadays, the work of a technical specialist, is related to technique and technologies, and during all the time takes place in conditions where it's necessary to develop a plan of actions, use modeling and forecasting methods, and take decisions. Information technologies put forward new requirements for a technical specialist. The result of this technical specialist training should be the ability to self-study. The achievement of which is possible only for a person with a high level of professional self-dependence, creative potential and competitiveness [1,2]. Only a specialist with a fully developed spatial awareness is able to ensure the implementation of these requirements. Spatial awareness - is type of mental activity, which ensures the formation of spatial images and their application in the process of solving practical and theoretical problems, and also acquires its development throughout life [3].

Spatial awareness begins to form in school and continues in higher education. But in modern school education, there is paid to disciplines that form the spatial awareness and this results into the fact that spatial awareness of school graduates is formed at a very low level [4].

In higher education institutions, the formation of students' spatial awareness is rested upon the discipline "Descriptive Geometry", which for the unprepared freshman seems difficult and incomprehensible. Therefore, the development of new approaches towards the formation of the spatial awareness of the future technical specialist at the beginning of training is up-to-date.

Purpose. To increase the efficiency and lay a foundation for an integrated approach for the formation of the spatial awareness of the applicant for technical education during the basic course.

We have solved the following tasks in order to achieve this goal:

1. To analyze the state and develop a model of spatial awareness formation of technical education students, as a process of mastering graphic disciplines. 
2. Give consideration to a comprehensive approach of development of the spatial awareness of students during the basic course.

Materials and methods. Spatial awareness is an individual feature that receives its highest degree of development via techniques of engineering creativity. The gained knowledge as a result of long and hard work are maintained throughout life. Since during the study of "Descriptive Geometry" there is a need for independent work of applicants with literary and reference sources, such activities set the future specialist for hard work, awareness of acquired skills, practical understanding of theoretical knowledge, which in its turn increases the desire to get better results. Receiving an independent solution to the problem, applicants experience creativity, and this attracts them to the subject, raises their interest, creates pleasure from classes.

The main direction towards a preparation for technical activities is to carry out independent graphic works and solve positional problems. The utilization of the individual tasks method during classes forms the ability to navigate in the information of the course, to gain skills of its processing and research, to learn to achieve results independently. Graphic works help to increase confidence in personal strength, knowledge, have a creative and research direction, significantly stimulate the sustainable development of spatial awareness and influence the personal qualities of the future technical specialist.

The process of development of the higher education applicant's spatial awareness at the initial stage of its obtainment can be considered as a gradual mastering of graphic direction disciplines and can be presented in the form of a model (Figure 1).

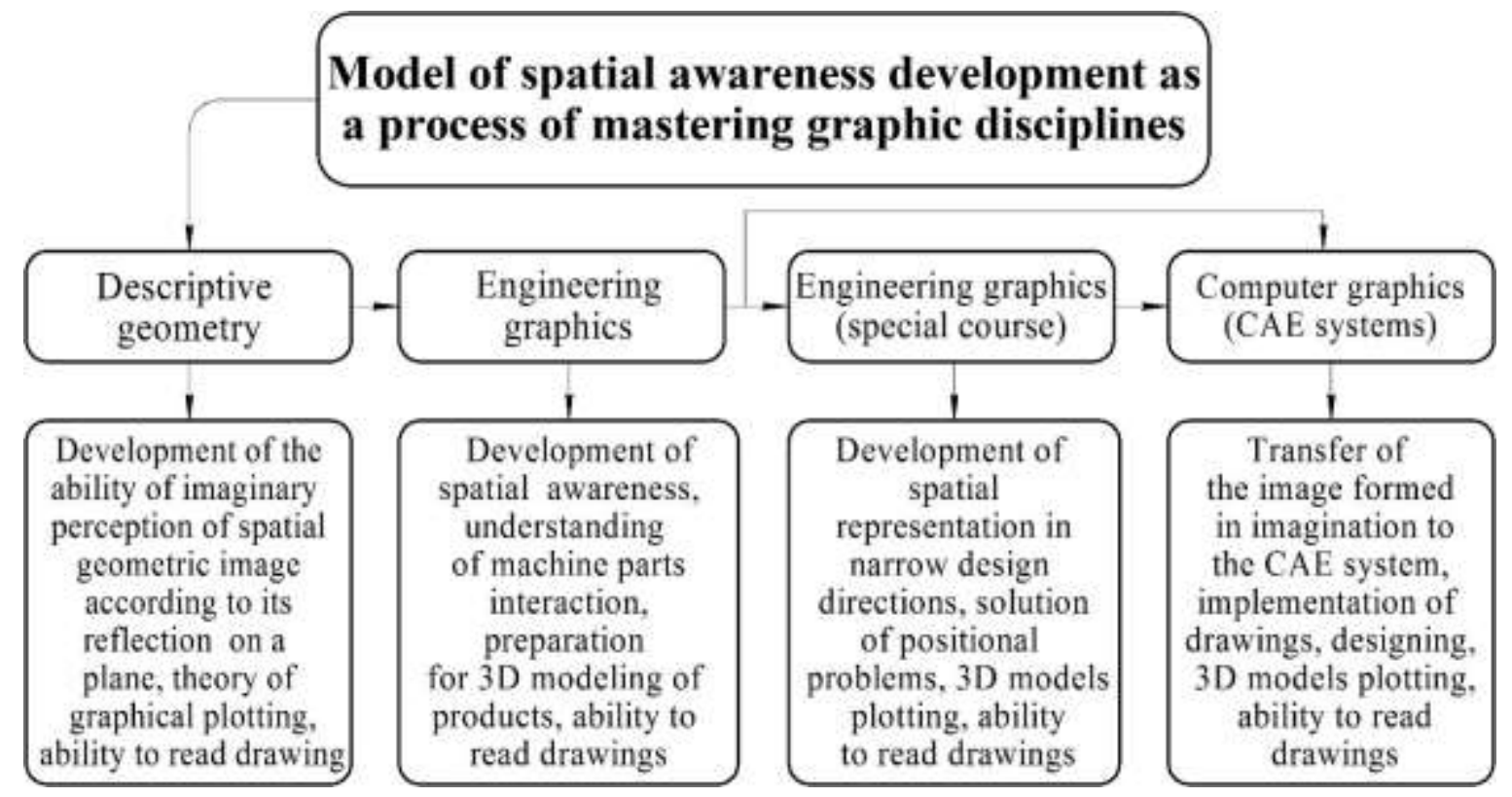

Figure 1. Model of development of spatial awareness as a process of mastering graphic disciplines

Analyzing the model, we see that the key moment is a full mastering of the first graphic discipline "Descriptive Geometry". Since it is very important to master the first topics of the course, in particular at this stage, it is necessary to ensure maximum clarity and visibility of all the concepts that are taught.

Results and discussion. At the initial stage of spatial awareness formation, the applicant needs: to acquire skills of graphic modeling; perform two types of images - 
on the plane (drawings in projections) and in three-dimensional space (axonometric images), to see the relationship between them [5]. In the classical course of "Descriptive Geometry" teaching, all constructions take place on a plane with a further transition to spatial constructions, which causes difficulties in the applicants' perception whose spatial awareness is poorly developed.

That's why, for greater clarity and visibility, we propose to consistently and at the same time simultaneously work on the task at once on the plane and in the spatial model. This gives the applicant the opportunity to get a clear understanding of the result of construction and the result of solving the problem.

An example of using the approach is to accomplish the task of constructing a complex drawing of a point that is located not in the first octant (has negative coordinates). To simplify the construction of point projections in any octant: it is necessary to know the location (signs) and direction of the axes for the fully-fledged first octant (they are all positive); construction begins with the direction of the axes, if the coordinate sign is negative - the axis is directed in the direction opposite to the positive value of the first octant; we explain this on the spatial model. Figure 2 shows a consecutive, in 4 steps, solving the problem of finding a point in the second octant.
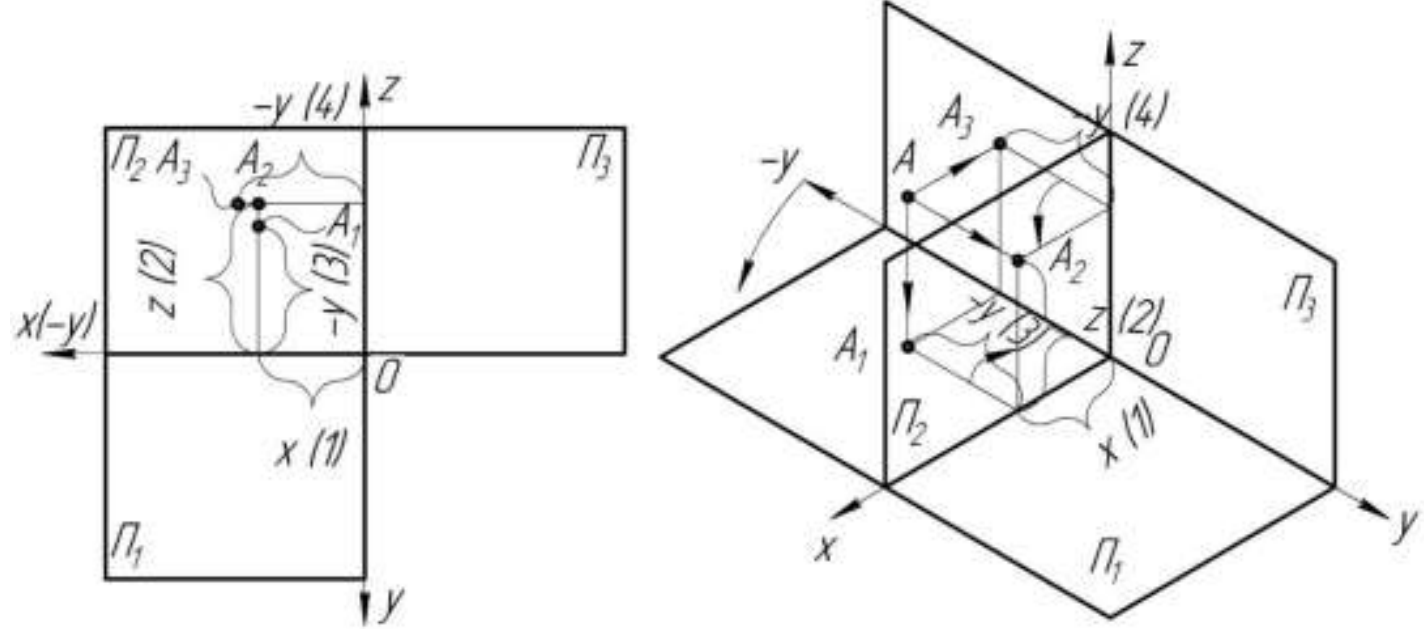

Figure 2. Spatial model and complex drawing of a point located in the second octant

The construction of the point projections begins with a front $A_{2}$ which has coordinates $(\mathrm{x} ; \mathrm{z})$. From it, on a vertical connecting straight-line will be located horizontal projection of a point $A_{1}$ with coordinates (x; y). We would like to emphasize that the attention should be paid to the fact that $A_{2}$ and $A_{1}$ are always located on the same vertical connecting straight-line because they have the same coordinate - $\mathrm{x}$. The profile projection of the point $A_{3}(\mathrm{y} ; \mathrm{z})$ is sought on the horizontal connecting straightline with the projection $A_{2}$ so far as their mutual co-ordinate is $\mathrm{z}$.

The next topic of "Descriptive geometry" is the projection of a straight-line. Let's consider the case of the straight-line location in different quadrants. The simplest and clearest is to build a level line. 


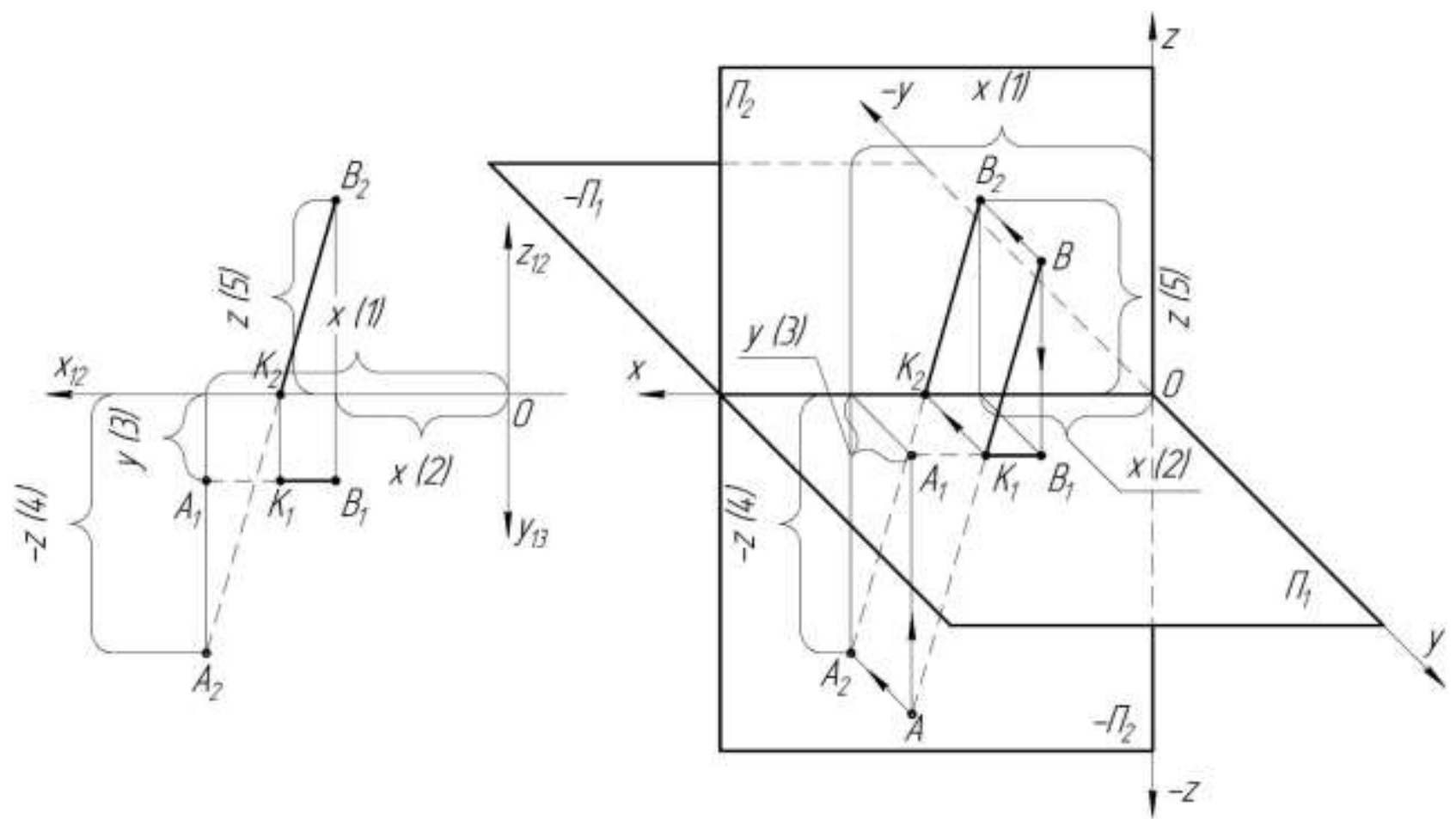

Figure 3. Complex drawing and spatial model of a straight line, which is located in different quadrants

Figure 3 shows how in 5 steps you can get a complex drawing and a spatial model of the frontal line which is in different quadrants. The obtained visual image and a complex drawing of the solution of the problem allow the applicant to acknowledge the course of construction and more fully understand and imagine the performed processes.

The suggested approach helps applicants to move more easily to the next sections of the "Descriptive Geometry" course due to simplified teaching of basic concepts and consolidating the ability to move from the spatial representation of the condition and problem solving to the representation on the plane and vice versa.

Gong forward, based on the obtained results, it is planned to improve the approach towards teaching the following sections of the "Descriptive Geometry" course.

Conclusions. As a result of the conducted research, it was defined that the main problem at the initial stage of the training of applicants in technical education is their low level of preparation. With the purpose of spatial awareness formation speed-up and faster understanding of the subject by applicants, there is suggested a comprehensive approach with a combination of complex drawing and spatial model of obtaining solutions for set problems. This approach secures high clarity and comprehensibility, and applicants have the opportunity to speed-up the formation of spatial awareness at the initial stage of studying.

\section{References:}

1. 01.07.2015. The Law of Ukraine №1556-VII "On Higher Education" (in Ukraine). - Kyiv: 72. (in Ukraine). https://ru.osvita.ua/legislation/law/2235/

2. 29.12.2004. Directory of qualifying characteristics trades workers. Volume 1. "Professions workers, that are common to all economic activities." Chapter 1 
"Professions managers, professionals, experts and technical staff" (in Ukraine). https://zakon.rada.gov.ua/rada/show/va024203-98

3. Rusinova, L.P. (2012). The development of spatial thinking in students at the beginning of the course "Descriptive Geometry". Young scientist, 3, 391-394. (in Russian). https://moluch.ru/archive/38/4430/

4. Skoriukova, Ya.H. (2017). An analysis of the current situation and ways of developing spatial thinking of students in the study of descriptive geometry. Materials of the XLVI Scientific and Technical Conference, March 22-24, 2017, 3. (in Ukraine). https://conferences.vntu.edu.ua/index.php/all-fksa/all-fksa2017/paper/view/1832/1945

5. O. Artemenko, D. Artemenko, S. Martynenko, N. Cherednychenko. Specific Nature of Spatial Awareness Formation of the Bachelor of Technical Higher Education Institution of Ukraine During the Basic Course // Journal of Technical Education and Training Vol. 12 No. 2 (2020) p. 87-98. URL: https://publisher.uthm.edu.my/ojs/index.php/JTET/issue/view/205 


\title{
USE OF GAME TECHNOLOGIES IN THE PROCESS OF FORMATION OF PEDAGOGICAL CREATIVITY OF FUTURE TEACHERS OF ART DISCIPLINES
}

\author{
Bartienieva Iryna, \\ Candidate of Pedagogical Sciences \\ Senior Lecturer at the Department of Pedagogy, \\ South Ukrainian National Pedagogical \\ University named after K. D. Ushynsky \\ Nozdrova Oksana, \\ Candidate of Pedagogical Sciences \\ Senior Lecturer at the Department of Pedagogy, \\ South Ukrainian National Pedagogical \\ University named after K. D. Ushynsky
}

The problem of formation of pedagogical creativity of future specialists has always been and will remain one of the most urgent problems of the theory and practice of pedagogical science.

The analysis of world tendencies in the field of education, in particular professional and pedagogical, testifies to the need to put forward ever higher requirements to the personality of a professional teacher, a creative teacher [1].

Problems of formation of pedagogical creativity of teachers have multifaceted coverage. Namely, this problem was considered by V. Andreev, V. Kan-Kalyk, M. Nikandrov, M. Potashnyk, S. Sysoyeva and many others. Pedagogical creativity is interpreted as an activity that generates new original solutions in the pedagogical interaction of teachers and students [2]. The pedagogical creativity of the future teacher of art disciplines is carried out and manifested during lessons, competitions, screenwriting, educational activities and more. But in the process of professional training of students in higher education, the learning process is traditional. After graduation, after becoming certified professionals, students have difficulty in performing their professional duties as a teacher of art disciplines [4].

The purpose of the study is to characterize the expediency of using game learning technologies in the process of forming the pedagogical creativity of future teachers of art disciplines.

It depends on the teacher whether students will have an interest in learning something new, how well they will learn this new, creatively use knowledge in practical life. Therefore, we believe that the introduction of disciplines «Fundamentals of pedagogical skills», «Art pedagogy», which we consider as integrative courses for professional and pedagogical training of future teachers of art disciplines should become the core, providing for the formation of creatively active teachers [2 ].

The educational process should take into account the trends of socio-economic development of society, especially the psychology of youth, and methods and forms of 
learning to implement in practice: the principles of initiative, individualization, independence, competition, creative approach to knowledge. Students should effortlessly strive for systematic, fruitful educational and creative activities. It is established that game competitions in most cases give a much greater effect in increasing the creative activity of students than their external motivation. Therefore, to implement these requirements, a significant place in the pedagogical activities of the teacher should be occupied by game teaching methods. The game method is characterized by three main features: 1) determines the purpose aimed at the content of education to be mastered; 2) provides a type of educational and cognitive activities; 3 ) determines the nature of the interaction between teacher and students [2].

If we analyze the activities of man from the standpoint of modern science, it turns out that the game in it occupies a leading place and is one of the needs of man. At the biogenic level - is the need for movement activity, at the psychophysiological - the need for emotional saturation, at the creative - the need to overcome, to express the will. The educational process, built on the basis of game teaching methods, helps to intensify the cognitive activity of students, to realize the creative components of personality development. A. Makarenko noted: «... in the game a person actively acts, thinks, builds, combines, models human relationships». Under these conditions, she performs various roles in the game: organizer, performer, creator, finds the conditions to identify their abilities and vital activity [4].

Compared to other forms of learning, game methods have the following positive aspects: high efficiency in the acquisition of knowledge and the formation of skills and abilities; the ability to cooperate is formed; learning motives are formed; developing humane relations between students; educational and creative activity (planning, reflection, control, self-control) develops. In the didactic game, learning tasks are indirect, which ensures their effectiveness. K. Ushinsky wrote: «... in the game all aspects of the human soul are formed: its mind, its heart and will» [4].

Didactic game is a way of interaction between teacher and students, due to the game situation, which leads to the implementation of didactic tasks and learning goals. The purpose of didactic games is to intensify the process of cognition of the student audience, to delve into the content of the discipline being studied; to develop skills of collective interaction, to gain experience of creative activity, and also to define a level of preparation of future teachers of art disciplines.

In modern conditions of secondary school reform, the need and importance of the use of didactic games in the system of educational work is beyond doubt for teachers and methodologists, as well as for teachers-practitioners. However, the practical implementation of this requirement in the pedagogical experience of teachers of art disciplines encounters obstacles. This is due to many reasons, among which the main, in our opinion, is the lack of scientifically sound guidelines for the use of game teaching methods in the classroom.

Analysis of the results of purposeful observations shows that didactic games, as a rule, are used sporadically, without a detailed method of processing them.

The success of this work, as evidenced by the results of the study, is determined by a set of interrelated didactic conditions that ensure the effective use of didactic games in the classroom, namely: 
1. The use of didactic games in lessons should be the norm of pedagogical practice, because this type of educational work activates various spheres of human life: intellectual, volitional, emotional.

2. Before each lesson with the students, the teacher should think of a lesson, which should consist of several small, carefully thought-out parts, united by a common theme and purpose, with the obligatory use of game moments. The story, conversation, search work should be combined with a didactic game, a situation of success, the use of means of interest (clarity, surprises).

3. The teacher directs the process of cognition in the right direction, if not oversaturated the process with entertaining techniques; changes the activities in the lesson; uses clarity; feasible independent work for children; correctly evaluates students; selects cognitive tasks according to the capabilities of students.

4. As it turned out, most teachers have difficulty in selecting a variety of visual aids for frontal and individual use. It is necessary to create sets of handouts for individual work and in a group (usually in pairs) for each topic from different disciplines, because the use of didactic material is stimulating for the emergence of positive emotions from the perception of the form of the task. This equipment saves time, quickly switches children's attention from one type of activity to another, teaches them self-control.

5. Underestimation by teachers of the importance of an individual differentiated approach to the organization of student learning through didactic play reduces cognitive activity and, as a consequence - mental fatigue of children. Thus, the problem of differentiation in education is acute. It is advisable, in particular, to use special didactic games for students with a high intellectual level. On the other hand, separate didactic games are needed for students who need special attention from the teacher.

6. Some teachers do not follow psycho-hygienic norms when using didactic games and visual methods in the educational process, which leads to excessive emotional overload of children. Therefore, it is important to conduct games systematically and purposefully in each lesson, starting with elementary game situations, gradually complicating and diversifying them as students accumulate knowledge, develop skills, develop logical thinking, cultivate intelligence, independence, ie such qualities. intellectual sphere, which characterize the creative personality.

We implemented the idea of using world-famous intellectual games («KVK Competition», «Brain Ring», «What? Where? When?», etc.) in the educational process as a separate element of educational and creative activities of students in the current, intermediate or final control of knowledge in the study of the discipline «Fundamentals of pedagogical skills», «Pedagogy of art», used different types of didactic games.

Thus, the use of didactic games in the study of the discipline «Fundamentals of Pedagogical Skills», "Art Pedagogy» not only stimulates, encourages students to acquire knowledge in the process of such activities, but also forms the pedagogical creativity of future teachers of art disciplines.

Conclusions. The use of the game method in the educational process, which is the main at all stages of the current, intermediate, final control of knowledge very effectively affects the formation of pedagogical creativity of future teachers of art disciplines. Implementation of the training system involves the maximum expansion of creative elements of future professionals through the use of game forms of control 
(didactic games), the implementation of the principles of individualization, competition, pedagogy of cooperation.

\section{References}

1. Kondrashova L.V. Imitation and game training in high school: A textbook. Krivoy Rog, 2001. 194 p.

2. Scherban P.M. Educational and pedagogical games: Textbook. manual. Kyiv: Higher School, 1993. S. 40-42.

3. Yavorskaya G.Kh. Game in didactic models of educational process in high school. Odessa: NIRIO ONVD, 2000. 114 p.

4. Yarmachenko M.D. Current issues of pedagogical science. Kyiv: «Knowledge», 1978. $48 \mathrm{p}$. 


\title{
THE DEVELOPMENT OF SOFT SKILLS IN THE CONTEXT OF TEACHING FOREIGN LANGUAGES
}

\author{
Buchynska Tetiana \\ $\mathrm{PhD}$, Associate Professor \\ West Ukrainian National University
}

The requirements for future specialists in all areas have been significantly changed in terms of increasing the importance of the information component of modern society. That is why it is very important to identify which skills will be important in the nearest future. Nowadays the labor market is increasingly using computer technology, which perfectly copes with well-structured tasks. But the universities have to prepare the specialists who will think better and more efficiently than computers, who will use their creativity and emotional intelligence. That is why soft skills play an important role in nowadays educational process. Integrating the usage of soft skills in the process of teaching will help to bridge the gap and foster the development of personal and interpersonal skills. In this fast-paced, globalized world, soft skills are becoming increasingly more critical for businesses and major differentiator for employability and are considered the skills of the 21-st century. In terms of Ukraine's integration into Western society, communication in foreign languages acquires special significance. If we analyze the teaching methods used in foreign language teaching in higher educational establishments, it becomes clear that the advantage still remains for tasks that require routine actions, and a much smaller percentage of tasks require students to solve poorly structured tasks or difficult organized communication. Thus in the context of teaching foreign languages soft skills should play the major role as the student must be able to solve the problems, to work in teams and be able to use the foreign language i.e. to communicate effectively. A lot of CEOs say they find soft kills more important and difficult to master than the knowledge they can master in the workplace. Given the growing demands of the modern labor market, the most relevant way to improve the employment skills of graduates and increase their adaptation to the needs of the labor market is to develop their soft skills [2; 4].

The list of flexible soft skills includes a large number of personal, communicative and managerial qualities, namely: networking and teamwork, analytical skills, digital competence, flexibility and adaptability, organization and negotiation, leadership and ability to delegate, ability to explain ideas and persuade others, ability to listen to other people, conflict resolution, emotional intelligence (ability to understand emotions), empathy, tolerance, ability to take responsibility, work in critical conditions, global competence, time management, public skills speeches and self-presentations and cross cultural communication. The teaching of foreign languages acquires special relevance and significance in the context of the development of soft skills. The purpose of mastering this discipline in higher education is the formation of universal competencies such as the ability to communicate orally and in a written form in a foreign language, to solve problems of interpersonal and intercultural interaction, the ability to work in an intercultural team, tolerant social, ethnic, religious and cultural differences. In this 
context the methods such as case study, debates and discussions, project-based learning can be used which have the potential to equip students with the core skills through reallife scenarios and different learning experiences. Thus, it is obvious that in addition to the formation of foreign language competence a lot of attention must be payed to master such flexible skills and abilities of the 21-st century as teamwork, communication and emotional intelligence $[1 ; 3 ; 5]$.

Summarizing the above we come to the conclusion that the modern labor market puts soft skills on the first place, among which the knowledge of foreign language plays a leading role. Low foreign language proficiency and a lack of soft skills are serious barriers to employment. Language learning outcomes should support mobility and personal growth. In order to provide the professionals with soft skills and meet the requirements of employers for qualified staff capable of performing a number of work-related tasks, it is important to ensure proper language learning in all levels of education. Thus students are given the opportunity to develop leadership, communication, critical and creative thinking, time management, team building skills. These are the skills that provide the professional and life success of each individual and the prosperity of the whole society.

\section{References:}

1. Baily, F., \& Lene, A. (2013). The personification of the service labor process and the rise of soft skills: A French case study. Employee Relations, Vol. 35.2013, p.79-97.

2. Chin, S., Anantharaman, R., \& Tong, D. (2015). Emotional intelligence and organizational performance: A framework. Global Business \& Management Research, Volume 7, p.37-43.

3. Coyle, D., Hood, P., Marsh, D. 2010. CLIL. Content and Language Integrated Learning. Cambridge University Press.

4. EC Special Eurobarometer 417. "European area of skills and qualifications", Report. JJune 2014. http://ec.europa.eu/public_opinion/index_en.htm

5. Mehisto, P., Marsh, D., Frigols, M.-J. 2008. Uncovering CLIL. Content and language Integrated Learning in Bilingual and Multilingual Education. Macmillan Books for Teachers. 


\title{
DIGITAL DIDACTICS: AIM, PRINCIPLES, ASSESSMENT
}

\author{
Golub Tetiana, \\ PhD., Associate Professor \\ National Technical University of Ukraine \\ "Igor Sikorsky Kyiv Polytechnic Institute"
}

The global transition to digital education testifies to the active growth of the digitalization process relevance. Formation of a successful digital education is one of the most significant policy priorities in many countries all over the world. We will share the principles of effective integration of digital technology into the educational process.

Digitalization is a mutual transformation of the educational process formed under modern conditions and by modern technical means implemented to educational process. The aim of such a transformation is to use the capabilities of digital technologies in educational process with maximum efficiency. In turn, the goal of developing technologies in the field of education is their complete adaptation and the most convenient integration to educational environment for the most comfortable solution of educational tasks.

There are three components of the digital society that give rise to the need for digital didactics:

- digital generation (a new generation of learners);

- digital technologies (that form the digital environment and develop in it);

- digital economy (and the new requirements for personnel generated by it).

Digital economy is the main source of educational goal-setting. Digitalization of economic sphere noticeably changes the educational area, shifting the focus to the need to form a complex of new digital competencies, regardless of the profession or speciality being acquired. This complex, in addition to the IT-competencies, which ensure the readiness of the employee to use computer and digital technologies, includes a wide range of other professional and universal competencies, the content of which is significantly transformed under the influence of digitalization.

Digital didactics is a branch of pedagogy aimed at organizing the education in the context of digitalization of society. It uses the principles and basic concepts which are traditional for didactics but transforms and supplements them adapting to modern digital realities. Digital didactics is the basis for development of modern teaching methods and strategies.

Access to the best educational institutions and specialists in all areas of expertise. Open educational resources of universities, research centres and institutions, electronic libraries become available to everyone. Nowadays a teacher can use a huge amount of ICT tools and information resources, but this does not always mean that he/she is using the necessary pedagogical approaches developed for their application. Many digital technologies have didactic properties like interactivity, multimedia, hypertext, personal orienting, etc., which make it possible to use them for creating an educational process considering the peculiarities of the digital society (Golub, 2020) 
In the digital age, a revision of traditional approaches to education is required: the reconceptualization of didactics and pedagogy, which is a prerequisite for the effective use of ICT in educational levels. According to M. Choshanov, digital pedagogy should be based on the following four principles:

- genuine individualization of learning,

- expanding experience,

- deepening knowledge,

- learning in a global context (Choshanov, 2013).

The aim of changes in educational process organization in the terms of digitalization is to increase its pedagogical performance. It can be achieved, first of all, due to the individualization of teaching - the transformation of a single and common educational process for all into a set of individual educational routes based, on the one hand, on the personal educational needs and requests of students, on the other, on their individual psychological and pedagogical and medical (for students with disabilities) features. Digital technologies are able to provide an almost infinite number of areas of training individualization, including by:

- content,

- the rate of mastering the educational material,

- the level of complexity,

- the method of material presenting,

- the educational activities organization forms,

- the study group composition,

- the external assistance,

- the degree of openness and transparency, etc.

It is important to implement all these areas simultaneously, which allows teacher to customize the educational process for each student.

Effectiveness assessment of digital learning is carried out in three directions:

- inclusive assessment,

- personal digital footprint,

- multi-level monitoring.

Digital technologies make educational assessment a continuous, personalized process, if necessary, complex (generalizing) or, on the contrary, selective. The most important characteristic of this process is operational feedback, which provides the student with information as for the quality of learning action he/she has just completed and, if necessary, with point recommendations on how this action should be corrected (included assessment). Information about the quality and effectiveness of the educational activities performed is transparent for the teacher and other subjects of the educational process.

The stages of consolidation and control (current assessment) of learning outcomes are integrated, ensuring a successful solution to the problem of complete assimilation. At the same time, the leading ones are the diagnostic, formative and motivating functions of educational assessment. In addition, inclusive assessment can be used to form and develop students' reflexive self-assessment skills. 
A significant part of professional skills formation can be fully automated using the technology of inclusive assessment. At the same time, for the final assessment of professional and general competencies, just computerized forms of assessment are not enough; an expert assessment is required, carried out by qualified specialists.

The technology of digital footprint is of great importance in digital didactics, which makes a longitudinal approach to become the norm of the educational process, in a cumulative mode, tracking individual indicators of development and educational results of a student, recorded in the process of included assessment. Big Data technology allows to monitor the educational process at the levels of:

$>$ a study-group, course, department, university, educational network; an educational program, educational module, etc.

It becomes possible both to track the dynamics of changes and to carry out a comparative analysis. The data obtained can be used for the operational improvement of the educational process.

The digitalization of education will result in effective education based on individual educational processes and continuous monitoring of the students' activities. Digitalization significantly expands the possibilities of using group and individual forms of work, ensures the full assimilation of professional knowledge and skills and significantly affects the development of inclusive education. Digital didactics implies a systematic solving of educational problems by means and methods of modern society remaining the essence of education to be the same.

\section{References:}

1. Golub, T. (2020) Immersive technologies in education. Modern engineering and innovative technologies. 11(2). P. 102-105.

2. Tchoshanov, M. (2013) Engineering of Learning: Conceptualizing e-Didactics. UNESCO Institute for Information Technologies in Education. 194 p. URL: https://iite.unesco.org/pics/publications/en/files/3214730.pdf. 


\title{
EDUCATIONAL TECHNOLOGY IN VOCATIONAL GUIDANCE OF SENIOR SCHOOL STUDENTS AS A CONDITION OF EFFECTIVE VOCATIONAL SELF- DETERMINATION
}

\author{
Ohrimenko Zarina \\ PhD in Pedagogy, \\ Head of the Laboratory for Education of Readiness for the Labor Market \\ Institute of Problems on Education of the of the NAES of Ukraine
}

Contemporary labor market is in the process of transformation and drastic changes, - that is the global world problem in the context of vocational guidance work with students. Some professions disappear, others have just arisen; many professions are undergoing modifications due to automatization and mechanization of professional activities. The previous experience of industrial revolution, namely a lot of new jobs, vacancies, new professions and business possibilities and high demand for new qualified workers, has not justified itself. Today's realities have proved that new technologies did not bring about new working places.

That is why the author of the article agrees that contemporary young people have to be ready to labor market changes as constant and unpredictable. As Sabina Žagar [1] argues, education system is stable, thus it is not ready to react to challenges so quickly. The researcher states that modern education faces a fundamental problem in terms of its tradition and mission in society: What should students study? For knowledge obtained in school should be useful all lifelong. Thus, school vocational guidance has a new challenge - to prepare students to an effective creative professional life under contemporary conditions.

In this light, the need of vocational guidance for students seems to be of high importance. Vocational guidance remains one of the most efficient mechanisms of assistance for a person in terms of his ไher choice of profession, profession change, or looking for a job.

Vocational guidance can also be viewed as an important instrument of forms, methods, and means that takes into account a person's individual characteristics, interests, and potential. Besides, labor market needs and requirements, and professional career management are also included in the list of vocational guidance.

Vocational guidance work at school in Ukraine is an integral part of the educational process aimed at:

- formation of skills of choosing a professional career that corresponds to his ไher abilities and inclinations, psychological features and labor market needs,

- increasing a person's competitiveness on the labor market,

- high productivity of the labor market.

However, it should be noted that vocational guidance of late in Ukraine is marked by old content, is mostly fragmentary and sometimes formal. These vices can be attributed to a number of factors, in particular: 
- lack of academic hours in curricula,

- teachers are not prepared to vocational guidance work with students

- Etc.

The factors noted above has a negative impact on the process of students' selfdeterminations, the consequence of which being retardation of vocational selfdetermination. Senior school students are trying to go to any higher educational institution in order to understand their professional interests better, get a better orientation in the labor market, and only then make a conscious choice of an activity. It often results in a change of professional activity after graduation or an aspiration to get another education.

The empirical research has proved the abovementioned facts. The results of the questionnaire on individual vocational self-determination of senior school students are as follows:

Among 230 students of general educational establishments -

$14 \%$ - have a completely formed system of knowledge on future profession,

$29 \%$ - have an insufficient system of knowledge on future profession,

$57 \%$ - have a superficial and non-systematic system of knowledge on future profession.

Among the interviewed, 67\% respondents answered "go to higher educational institution" when asked "What should you do in order to achieve success in your career development?", Besides, majority of students do not correspond their future working activity with their own individual characteristics; they do not know their future profession's requirements to a person's individual and psychological features; the students do not think about career values; they do not take into consideration the labor market needs in representatives of the chosen field. These results testify the fact that vocational self-determination of senior school students as for today requires a sufficient and effective vocational guidance support.

In the author's of this article view, the problem outlined can be solved through creation of a vocational guidance space aimed at assistance for a student to get a better orientation in a huge informational field under labor market instability and values transformation.

A system of educational impacts in such a space should be modelled with the students' individual and age characteristics taken into account.

Thus, school vocational guidance has to be composed of some educational technologies as a set of psychological and pedagogical suggestions that define a selection and a composition of forms, methods, and means of educational activities. The content of these forms, methods, and means should be aimed at a certain vocational guidance result. Therefore, any vocational guidance technology can be viewed as a set modes, ways, principles and methods of vocational guidance stipulated by its goals and tasks, an order of their implementation, and necessary instruments.

Diagnostic procedures, which contain criteria, indices and instruments of measuring the results of a student's vocational guidance activity results are an important element of a vocational guidance technology.

A student's position, a student's attitude, a student's activity in own selfdetermination are to be included in a vocational guidance technology described above. 
As academician Ivan Bekh [2, p. 123] argues, a technology should include a simultaneous development of education and self-education processes.

Now, a technology in vocational guidance work should be based on the methodic spectrum of a personality-oriented approach. A personality-oriented approach is composed of forms, methods and ways corresponding to:

- dialogic character of communication,

- activity and creativity,

- individual development support,

- a freedom space for a child to make independent decisions, be creative, to choose education content and means, to choose a behavior.

In Oleh Morin's point of view [3, p.12], a vocational guidance technology should perform functions such as:

- educational,

- psychological,

- developmental.

Educational function includes: future professional activity content, selfassessment of own individual peculiarities, knowledge on career algorithms.

Psychological function comprises: motives to self-development and stimuli to self-regulation of behavior.

Developmental function envisages: formation of a positive attitude to own professional future.

As we argue, the basis of the development process of a vocational guidance technology has to be an activation (actualization) of a person's value sphere. For, value orientations, on the one part, are the most important elements of a person's inner structure forming a person's stability in requirements, needs, interests and inclinations. On the other part, every professional activity is linked, to a certain extent, with requirements to a person's value orientations. It is also an environment for a person's needs to be satisfied.

As follows, a choice of one's future professional field can be an image of a person's future predicted. It can be said as well that a choice of one's life lines and selfrealization vectors is foremost a choice of dominant life values. Life goals and aspirations defining a person's future career will be formed after dominant life values have been formed. It is a development of reflection process in the context of career values content that makes possible formation of dominant life values.

As Ivan Bekh states, a student should be aware of his/her own personality that is constantly changing: "I was yesterday", "I am today", "I will be tomorrow".

In order for a subject to keep a stable aspiration to deed-activity based on positive emotional experience of ethic content (spiritual regulation), the subject has to experience this spiritual regulation, to link it with a notion about oneself, with formation of "I-image". Such a connection can be secured with help of selfconsciousness mechanism [2, p. 127].

However, one of the abovementioned technologies is an inclusion of the students' reflexive mechanisms appealing foremost to human self-consciousness and to a person's conscious creative attitude to professional values. 
It is such conditions that secure a student's self-determination as conscious knowledge of oneself, knowledge of a profession requirements and skills of corresponding one's individual features with a profession's requirements that invoke a senior student's value experiences and motivate to self-changes.

Thus, it is important for scientists and teachers to create such a technology in vocational guidance work that through interaction of the inner (a student's aspiration to self-perfection with requirements of future profession taken into consideration) and the outer educational impact (a system of vocational means) will create conditions for the determination of the inner processes of a person aimed at formation of readiness to choose a future profession.

\section{REFERENCES}

1. Žagar, S. (2019). The contemporary labour market: how to provide career guidance when we do not know exactly what future brings? Euroguidance Cross Border Seminar Skills for the future 14-15 May 2019. Bled, Slovenia, pp. 31-47.

2. Bekh, I.D. (2015). Vybrani naukovi pratsi. Vykhovannia osobystosti. Tom 1 [Selected scientific works. Education of personality. Vol.1]. Tchernivtsi: Bukrek. 840 p.

3. Morin, O. L. (2020). Doslidzhennia formuvannia profesiino-tsinnisnykh orienatsii uchniv do trudovoi diialnosti: poniatiino-katehorialny aparat [Research on formation of professional value orientations of students in terms of work activity: terms and categories]. Teoretyko-metodychni problemy vykhovannia ditei ta uchnivskoi molodi, $N$ 24, Book 2. Pp. 4-18. DOI https://doi.org/10.32405/2308-3778-2020-24-2-4-18/ 


\title{
VIRTUAL CLASSES IN DISTANCE LEARNING FOREING LANGUAGES FOR SPECIFIC PURPOSES
}

Zablotska Lyubov

Ph.D., Associate Professor

Meleshchenko Vira

Ph.D., Lecturer

Chernii Liudmyla

Ph.D., Lecturer

Ternopil Volodymyr Hnatiuk National Pedagogical University

\begin{abstract}
The article studies of the problem of effectiveness of virtual classes usage in the process of teaching foreign language for specific purpose in modern conditions of pandemic.

The practicability of multimedia technologies usage for the effective training process and the future specialists' foreign language competence formation has been proved.
\end{abstract}

Keywords: virtual classes, foreign language for specific purposes, foreign language competence.

The ability to use a foreign language by future specialists fluently, both for professional and private needs is of great importance nowadays. Moreover, the integration process of our country into the multicultural global educational and informational environment enhances the problem of the necessity of foreign language communicative competence formation for graduate university students. That is why the different aspects of the problem on formation of professional communicative competence in English as a Foreign Language (EFL) as well as English for Specific Purposes (ESP) has been the issue of numerous research papers.

Nowadays, the system of education faces the pandemic and quarantine inconveniences. In such conditions, caused by the modern reality, when the students of high educational establishments and universities are transferred on the distant form of education, the problem of usage information and innovative technologies for providing effective education has become more acute than ever.

In fact, the use of distance learning has not become a real challenge for the university teachers. Many universities began to create their own websites, providing access to electronic libraries, search engines and necessary documentation as well as a free and open-source learning management system Moodle with developed remote courses so that university teachers could combine traditional learning with some of it distant elements. 
Since spring 2020, universities all over the world have been innovating the way they deliver classes and teach students due to the innovative interactive techniques and the use of modern information means.

A virtual classroom is an online learning environment in which students and teachers interact via the technical tools provided by the software. To ensure hosting classes remotely while maintaining the functionality available in a traditional classroom environment, educational institutions use virtual classroom software, like Zoom, Google Meet, Big Blue Button, Adobe Connect, Cisco Webex Metings, Blackboard ant others.

In other words, the virtual classroom is a shared online space where the learners and the tutor work together simultaneously. Usually, these interactions take place through videoconferencing. The participants have tools to present learning content in different formats, as well as to implement collaborative and individual activities. In this type of interaction, the teacher has the particularly important role of the moderator who guides the learning process and supports group activities and discussions.

In fact, there is no a single definition of the notion "virtual class". In modern researches, two terms that are often interchanged are used. They are "Virtual Learning Environment" (VLE) and "Managed Learning Environment" (MLE). According to Margaret Rouse's (2011) opinion "A Virtual Learning Environment (VLE) is a set of teaching and learning tools designed to enhance student's learning experience by including computers and the Internet in the learning process [5]."

It is clear that distance learning cannot replace live communication with a teacher. However, in order to bring the distance learning format as close as possible to real communication, teachers were also offered various tools for organizing video conferences and online meetings, online whiteboard for real-time collaboration, instant messaging tool, participation controls, breakout rooms etc.

Such synchronous virtual classrooms have the great potential to provide significant benefit to online foreign language learning by addressing the needs of the learners as they relate to social interaction and psychological safety. They can also create a new standard in the learning experience that goes beyond the physical space of the classroom and traditional teaching methods.

Unlike asynchronous learning environment, the virtual classroom provides opportunities for self-studying; allows for instant feedback, direct teacher-student interaction, and engaging activities to increase motivation and active participation. Immediate communication favors relationship building within the group, as well as a sense of community.

Distance learning is impossible without the presence of EERs. Since the available EERs on various subjects do not cover all the necessary topics and, unfortunately, are not always high quality, teachers were presented with 10 services for creating their own EERs in the form of tests, quizzes, surveys, crossword puzzles, logic game resources, infographics, etc. Depending on the purpose of a lesson, a teacher can use the necessary service and create the EER on a particular topic [3].

Melnyk O.M. having made an overview of the most popular electronic educational resources that can be used in a virtual class points out the following: 
1. https://edpuzzle.com/ - the service that allows creating video clips with sound and text, as well as interactive quizzes and tasks for them. A teacher can voice a video, add voice comments and explanations to it, create classes and keep track of which students watched the video and how they coped with the suggested tasks.

2. https://www.liveworksheets.com/ - the service that allows converting materials in docx, pdf, jpg and png format into interactive material for selfexamination.

3. https://onlinetestpad.com/ua/ - the service that contains a designer for creating tests, surveys, quizzes, crossword puzzles, logic games, etc., as well as many readymade EERs in various subjects.

4. https://learningapps.org/ - the service that consists of a designer for creating interactive exercises and a collection of exercises developed by other teachers on various subjects and topics.

5. https://h5p.org/ - the tool for creating educational content in HTML5 format for all types of devices: computers, tablets, smartphones with many opportunities for studying educational material and assess the level of student's achievement.

6. http://www.flubaroo.com/ - the add-on to Google Forms for tests. This tool allows checking students' answers to test questions, get a report and analysis of academic achievement for each student, and send students grades with their test results with the key to the test or without it, and more.

7. http://crosswordcreator.homacosoft.com/index.htm - the program that allows creating crosswords easily.

8. https://kahoot.com/ - the online service, which allows creating electronic educational game resources, as well as quizzes, tests, surveys, etc.

9. https://www.classmarker.com/ - the test designer, which allows creating up to 100 tests per month free, add images, videos, audio files, formulas, etc.

10. https://piktochart.com/ - the tool for creating infographics on the network, which can be shared on social networks, save to a PC, get a code and links to embed infographics on a site [3].

Unlike asynchronous virtual platforms, the synchronous virtual classroom allows for immediate feedback from both the tutor and the other participants in both an individual and a general way. The key role of the tutor here is to create an atmosphere of positive feedback by guiding the group's interaction. The need for feedback, which acknowledges the positive aspects of the learners' performance and gives valuable comments and recommendations for improvement, benefits the education and progress of the students. It also builds the habit in the group of trying to maintain a positive and constructive tone. All of these factors are vital in assisting the learners to overcome their mistakes without feelings of negativity, as well as by fostering confidence and inspiring them to achieve their full potential.

Virtual classes have certain advantages. Thus, they provide personalized learning, as students are able to choose time and place for their studies and they can spend so much time as they require. Besides, such classes are considered as easily accessed by everyone from anywhere and at any time and they are affordable as well. Virtual classes enhance collaboration and communication and provide real-time teaching and learning. They introduce both students and educators to education new 
technologies; allow supplying learners with comprehensive online tutorials, improving visualization.

But, at the same time, we have to admit that there are some disadvantages of virtual classes. Among them we can name the following: lack or no control over the students or classroom; teachers find it difficult to keep under control learning atmosphere or environment; virtual classroom requires computers and constant Internet connection; students may experience lack real-time teaching experience ad, finally, there is always the risk to return to the traditional student-teacher collaboration.

\section{References:}

1. Заблоцька Л. М., Мелещенко В. О., Черній Л. В. Інноваційні методи навчання англійської мови за професійним спрямуванням у закладах вищої освіти / Інженерні та освітні технології. 2019. Т. 7. № 3. С. 85-96. doi: https://doi.org/10.30929/2307- 9770.2019.07.03.08

2. Заблоцька Л.М., Цар I.О. Використання віртуального освітнього середовища у дистанційному навчанні іноземної мови (VI Міжнародна науковопрактична Інтернет-конференція «Сучасні інформаційні технології та інноваційні методики навчання: досвід, тенденції, перспективи», Тернопіль: ТНПУ(12-13.11.2020)

3. Melnyk O.M. Overview of electronic educational resources for distance learning of Ukrainian schoolchildren // The 5th International scientific and practical conference -Actual trends of modern scientific research\| (November 8-10, 2020) MDPC Publishing, Munich, Germany. 2020. - P.191

4. Черній Л.В., Мелещенко В.О., Нагорнюк Л.С, ЗаблоцькаЛ.М., Цар I.О. Development of Journalists' Professional English Communicative Competence Using Mass Media”. Development of Journalists' Professional English Communicative Competence Using Mass Media". // Arab World English Journal (AWEJ) Special Issue on the English Language in Ukrainian Context, November 2020 Pp.234-243 DOI: https://dx.doi.org/10.24093/awej/elt3.20

5. Rouse, M. (March, 2017)/ Virtual learning environment (VLE) or managed learning environment (MLE). TechTarget. Whatls.com. Retrieved from: http://whatis.techtarget.com/definition/virtual-learning-environment-VLE-ormanaged-learning-environment-MLE 


\title{
ДЕЯКІ ПИТАННЯ ЯКОСТІ ОСВІТИ ПІД ЧАС ДИСТАНЦЙНОГО НАВЧАННЯ
}

\author{
Бубнов Ігор Васильович \\ кандидат історичних наук \\ доцент кафедри українознавства та соціальних наук \\ Одеський державний екологічний університет
}

Карантинні обмеженнями останнього часу, змусили вітчизняні виши до пошуку і впровадження різних засобів дистанційного навчання. Відразу слід визначитися із змістом поняття «дистанційне навчання». Треба чітко розуміти різницю між двома схожими термінами: «дистанційна форма освіти» i «використання дистанційних технологій» у різних формах освітнього процесу/

Дистанційна освіта передбачає можливість будь-якого громадянина, який має середню, професійну чи вищу освіту, а також здатний дистанційно виконувати необхідні завдання за допомогою відповідних освітніх технологій, у зручний для себе час навчатися та отримувати необхідні знання віддалено від навчального закладу. Такий процес навчання побудований на використанні різних комунікаційних засобів та завершується отриманням здобувачем вищої освіти відповідного сертифікату і диплому.

Якщо мова йде про «дистанційні технології в освіті», то мається на увазі використання конкретних платформ та інструментів (зокрема, Moodle, Google Classroom, Zoom, Skype тощо), які дозволяють учасникам освітнього процесу спілкуватися, виконувати і перевіряти завдання, контролювати відвідуваність, організовувати поточний і семестровий контроль тощо. Такі технології можуть бути інтегровані на будь-якому етапі опанування відповідного навчального курсу. За такої форми організації навчального процесу важливими $\epsilon$ ініціатива викладача щодо впровадження таких технологій та готовність студентів їх використовувати, а також технічна спроможність обох сторін ці технології застосовувати.

До впровадження карантинних заходів лише кілька десятків вітчизняних університетів мали сертифіковані права і формалізовані можливості щодо здійснення дистанційного навчання як форми надання освітніх послуг. Такі заклади вищої освіти вже мали: сформовані структурні підрозділи для адміністрування та консультування учасників процесу дистанційного навчання; відповідний практичний досвід; інноваційні напрацювання у сфері здійснення дистанційної освіти. Переважна ж більшість вітчизняних вишів до останнього часу обмежувалися лише використанням, тією чи іншою мірою, в навчальному процесі різноманітних дистанційних технологій. Проте, нові умови і виклики часу актуалізували використання таких технологій i систем управління навчанням (Learning Management Systems) i, при цьому, гостро поставили проблему щодо забезпечення належної якості освіти. 
Вирішення цієї проблеми потребує розв'язання низки питань технічного, організаційно-методичного, дидактично-психологічного характеру, що постали перед освітянською спільнотою.

За умов сучасної фінансової нестабільності формування необхідного інформаційного середовища, яке передбачає придбання i налаштування спеціального технічного устаткування та розгортання відповідного програмного забезпечення, стало серйозним викликом для більшості вишів. I, якщо за певних зусиль, в першу чергу матеріально-фінансового характеру, з часом це питання в цілому вирішується закладами вищої освіти, то проблема асинхронності темпів розвитку дистанційних технологій і динаміки змін у свідомості і рівні підготовки учасників освітнього процесу залишається дуже гострою.

Онлайн-навчання із використанням дистанційних технологій переконливо продемонструвало, що стандартно-традиційні підходи щодо організації навчального процесу, де викладач начитує матеріал, а студенти його слухають, вже не спрацьовують. I якщо певні адміністративні методи ще можуть хоч якось забезпечити віртуальну присутність студентів на онлайн-лекції, то їхню активність, зацікавленість і здатність ефективно сприймати нову інформацію викладач вже не здатен контролювати. Задля запобігання перетворення навчального процесу на імітацію, втримання належної уваги студентів, їх мотивування до навчання і не втрачання якості освіти, викладачі змушені знаходити, а інколи навіть винаходити, і впроваджувати нові підходи до викладання матеріалу. Це можуть бути заняття у форматі бізнес-ігор, групові дискусії з обговорення навчального матеріалу, проведення опитувань під час лекції, активне використання контенту з YouTube задля наочної демонстрації практично-прикладних фрагментів курсів тощо.

В сучасних умовах якість освіти значною мірою детермінована ступенем ефективності використання інструментарію дистанційних технологій і якістю інформаційного наповнення контенту онлайн-навчання. Це вимагає підвищення рівня педагогічної майстерності викладачів, їх цифрової освіти і культури, чого в реаліях сьогодення не можна досягти миттєво. Тому видається доцільним звернути увагу керівництва вишів на питання щодо організації роботи відповідних курсів підвищення кваліфікації співробітників, програма яких має бути зорієнтована на проблеми використання інформаційних технологій в управління навчальним процесом, розроблення і впровадження системи енавчання, створення привабливого і якісного онлайн-контенту, здійснення поточного i семестрового контролю в режимі електронних журналів i електронних відомостей. У якості обов'язкових питань в програмах таких курсів можуть стати такі проблеми як: методика проведення навчальних занять в онлайн-режимі; психолого-педагогічні аспекти комунікації зі студентами; формування внутрішньої цифрової дисципліни i культури; завдання забезпечення стандартів якості освіти тощо.

Виходячи з нагального питання про те, шо одним із ключових показників якості освіти в сучасних умовах виступає проблема працевлаштування молодого спеціаліста, закладам вищої освіти важливо враховувати погляд роботодавців на те, як дистанційна освіта впливає на якість підготовки фахівців. 3 одного боку, 
бізнесовим структурам однаково у який спосіб навчався потенційний кандидат на працевлаштування, головне - його готовність до виконання конкретних завдань на виробництві. Але, з іншого боку, для роботодавців важливо, аби процес навчання був конкурентоспроможним. Задля підтримання належного рівня якості освіти вкрай важливою $є$ конкуренція між освітніми закладами у сфері організації і запровадження дистанційного навчання, а також між освітою та іншими сферами життя. За умов цифрової трансформації (діджиталізації) сучасного світу дистанційні методи роботи стають широко розповсюдженим у багатьох сферах суспільного життя і тому класична освіта без дистанційної складової в житті молодого покоління може навіть виступати стороннім тілом

Впровадження дистанційної освіти - це також, певною мірою, цифрова трансформація і тому роботодавці можуть долучитися до цього через: участь в оновленні освітніх програм, сприяння матеріально-технічному оснащенні закладів вищої освіти, розвиток спільних дослідницьких проєктів, допомогу у підвищенні кваліфікації викладачів тощо.

Серйозною проблемою щодо забезпечення високого рівня якості освіти в системі дистанційного навчання є питання самомотивації і самоконтролю з боку студентів. Як виявилось, дистанційована від викладача форма навчання підходить далеко не всім, оскільки не у всіх студентів $є$ рівень самостійної організованості, необхідний для навчання у такому форматі. Саме відповідний мотив має забезпечити спонукання студентів до дистанційного навчання. Тому при розробленні онлайн-курсів недостатньо представити лише чітко відпрацьований навчальний матеріал, слід також формувати у студентів мотивацію, яка б сприяла їх самостійному навчанню. Серед способів підвищення мотивації студента можна виділити такі як: привабливе і цікаве технічне оформлення курсу з використанням малюнків, діаграм, схем, графіків; поділ курсу на окремі модулі із чіткими завданнями до кожного 3 них; розробка різноманітних варіантів навчальних завдань; налагодження своєчасного i конструктивного зворотного зв'язку з викладачем; провокування й підтримання духу змагання між студентами; наочна демонстрація студенту того, що він сам контролює ситуацію, що його успіх напряму залежить від зусиль, які були ним докладені. За таких умов можна підтримувати віру студента в свої сили, допомагати йому отримувати задоволення від навчання, а не сприймати його як важкий тягар [1, с.20]

Таким чином, проблема належного рівня якості освіти в умовах дистанційного формату організації навчального процесу потребує особливої уваги керівництва вишів і профільного міністерства у розв'язання низки питань фінансово-економічного, дидактичного, поведінково-методологічного i мотиваційно-психологічного характеру. Стрімкий перехід вітчизняних вишів на дистанційне навчання став великим і складним викликом, який приносить освітянському середовищу неабиякі труднощі та проблеми, але, разом з тим, це $\epsilon$ чудовим шансом зробити українську освіту більш конкурентоспроможною, гнучкою, привабливою і якісною. 


\section{Список літератури:}

1. Бубнов I.В., Мирошниченко М.I. 3 досвіду впровадження системи е-навчання у викладанні соціально-гуманітарних дисциплін // Управління якістю підготовки фахівців. Матеріали Всеукраїнської науково-методичної конференції ОДЕКУ. - Одеса: ТЕС. 2019. - С.17-21. 


\title{
ПРОБЛЕМИ НАВЧАННЯ В ПЕРІОД ПАНДЕМІЇ У ВИЩІЙ ШКОЛІ
}

\author{
Годлевська Наталія Аркадіївна, \\ К.м.н, доцент
}

\section{Старовєр Анжеліка Вікторівна,}

К.м.н., доцент

Вінницький національний медичнй університет ім.М.І.Пирогова

\begin{abstract}
Анотація. Досвід викладання практичних занять в вищому медичному навчальному закладі в умовах пандемії Covid-19 3 використанням умов наближених та адаптованих до практичної діяльності студентів з використанням платформи Microsoft Teams в on-line режимі.
\end{abstract}

Ключові слова :Covid 2019, Microsoft Teams, навчальний процес

Сучасний період пандемії в всьому світі змінив не тільки наш звичайний ритм життя але й вагомо вплинув на адаптацію до нового формату навчання особливо в вищих навчальних закладах. Особливо це має велике і вагоме значення для медичних вузів в яких не проводилась раніше заочна форма навчання. Але враховуючи складну ситуацію в світі і в Україні, в тому числі, виникла вкрай висока і життєва необхідність продовжувати навчання в таких складних і для студентів і для викладачів часи. Виникла необхідність адаптувати максимально швидко процес навчання з використанням всіх можливих наочних посібників, матеріалів, відеопрезентацій, симуляційних технологій в онлайн режимі 3 демонтстрацією і впроваджувати це в навчальний процес [1].

Процес навчання з елементами відеоматеріалів, презентацій був присутній і раніше на практичних заняттях, але така неочікувана для всіх зміна формату навчання в вищій медичній школі спонукала нас знаходити нові напрямки взаємодії, спілкування викладач та студент, до пошуку методів навчання максимально наближених до звичайного режиму навчання 3 можливістю практично бачити ті чи інші акушерсько гінекологічні методики обстеження, дослідження, маніпуляції та операції. На практичних заняттях намагались максимально розбирати нозології 3 відеонаочними матеріалами у форматі відеозаписів згідно теми практичного заняття, підготовкою презентацій студентами при яких вони займались пошуком наочного матеріалу. Обов'язково, згідно кожної теми, проводиться розбір тематичних клінічних задач з побудовою діагнозу, вибору необхідних методів обстеження та надання медичної допомоги згідно існуючим наказам та протоколам MO3 України з якими має бути ознайомлений студент. 
Нашою кафедрою в умовах пандемії та онлайн навчанням запроваджено проведення відеотрансляцій 3 моменту початку та завершення операцій які заплановані для студенства нашими професорами під час яких студенти можуть задавати питання та бачити що відбувається безпосередньо в операційній, повторювати і бачити анатомічні утворення, судини, зв'язковий апарат що $\epsilon$ кращим в засвоєнні матеріалу чим теоретичний розбір. Крім цього $є$ можливість переглядати такі відеоматеріали у запису в будь який зручний для студентів час. Важливим моментом $є$ те, що можливе навчання і починаючим викладачам, $\mathrm{i}$ аспірантам, i інтернам, і клінічним ординаторам також приєднуватись до проведення практичного заняття 3 викладачами які мають великий досвід в педагогічному процесі.[2]

Серед акушерських тем було цікаво студентам переглядати відеоматеріали періодів пологів 3 проведенням акушерських маніпуляцій та 3 коментарями свого викладача і можливості задавати питання які виникали по ходу пологів чи операцій кесарського розтину.

Різноманітність альтернативних способів надання допомоги студентам у навчанні, творчий підхід викладачів у розробці нових форм оцінювання та навчальної підтримки, а також готовність до впровадження нових технологій забезпечили позитивний вплив на навчальний процес загалом в умовах пандемії.

Однією 3 проблем яка виникла з нашого досвіду навчання є збільшення кількості пропущених занять студентами, які почали працювати в медичних закладах в зв'язку з необхідністю в медичному персоналі в умовах пандемії. Відповідно якість підготовки в таких складних умовах і так значно погіршилась по причині неможливості спілкування 3 пацієнтом, проведення необхідних зовнішніх методів обстежень акушерських та гінекологічних жінок, проведень спеціальних гінекологічних методів обстежень та проведень акушерських методів, які входять в навчальну програму та відносять до обов'язкових практичних навичок. Крім цього поясненням цьому $\epsilon$ незацікавленність студентів при звичайному спілкуванні по типу питання відповідь. Тому сучасні умови вимагають максимального зосередженння в роботі викладацького складу щодо зацікавленості до практичних занять які проходять онлайн та можливості отримувати на доступному рівні необхідну для засвоєння інформацію 3 використанням відео матеріалів по тематиці практичних занять.

Проведення занять в режимі онлайн має ряд переваг в плані можливості бути присутніми в операційній або пологовій залі, при проведенні лікувальних маніпуляцій повним складом групи без обмежень кількості студентів, максимально бачити хід оперативних втручань 3 коментарями хірургів, що не завжди $є$ повноцінним і можливим при звичайній формі навчання. Але $є$ і багато негативних моментів при такому виді навчання що має спонукати професорськовикладацький склад до пошуку можливих методів покращення навчального процесу в таких складних для всіх умовах 


\section{Список літератури}

1.Коньков Д.Г., Буртяк Н.Г. «Розгорнута аудиторія». Перспективи необхідності//Матеріали науково-практичної конференції 3 міжнародною участю «Медична симуляція - погляд в майбутнє». - 2020. - с. 4-7.

2.Марічереда, В. Г.; Могилевкіна, І. О.; Коньков, Д.Г.; Шмакова, І. П.; Рогачевський, О. П.; Борщ, В. І. Організація та проведення об'єктивного структурованого клінічного іспиту// Методичні рекомендації. - 2020. - 84 с. 


\section{ОСОБЛИВОСТІ ОРГАНІЗАЦІї ДИСТАНЦІЙНОГО НАВЧАННЯ ЗДОБУВАЧІВ ВИЩОЇ ОСВІТИ}

\section{Гончарук Віталій Володимирович,} кандидат педагогічних наук, викладач кафедри хімії, екології та методики їх навчання Уманський державний педагогічний університет імені Павла Тичини

Гончарук Валентина Анатоліївна, кандидат педагогічних наук, доцент, доцент кафедри української літератури, українознавства та методик їх навчання Уманський державний педагогічний університет імені Павла Тичини

\section{Подзерей Роман Вікторович,} викладач кафедри хімії, екології та методики їх навчання Уманський державний педагогічний університет імені Павла Тичини

Із розвитком комп'ютерної техніки, телекомунікацій та мережі Інтернет, дистанційне навчання отримало новий поштовх у своєму розвитку. У сучасних умовах модернізації системи освіти все більшу увагу приділяємо методам активного пізнання, самоосвіти, дистанційного навчання. Використання засобів IКТ в освіті дозволяє організувати і розвинути новий напрям - дистанційне навчання. Для безперервної підтримки здобувачів вищої освіти і забезпечення ефективності освітнього процесу в дистанційному навчанні розробляються спеціальні навчально-методичні комплекси, що дозволяють їм із більшим рівнем самостійності освоювати освітній контент і програмне забезпечення.

Дистанційне навчання через Інтернет стало невід'ємною частиною освіти в усьому світі. На сьогодні воно популярне в багатьох розвинених країнах Америки, Свропи та Азії. Очевидно, що у XXI ст. дистанційне навчання охопить весь світ. Українська освітня система вже активно запроваджує цю форму навчання, але вона ще і сьогодні має свої переваги й недоліки.

Дистанційне навчання розуміємо як індивідуалізований процес оволодіння знаннями, уміннями, навичками і способами пізнавальної діяльності людини, який відбувається в основному за опосередкованої взаємодії віддалених один від одного учасників навчального процесу у спеціалізованому середовищі, яке функціонує на базі сучасних психолого-педагогічних та інформаційнокомунікаційних технологій.

Завданням дистанційного навчання є забезпечення громадян можливістю реалізації конституційного права на здобуття освіти та професійної кваліфікації, підвищення кваліфікації незалежно від статі, раси, національності, соціального і майнового стану, роду та характеру занять, світоглядних переконань, належності до партій, ставлення до релігії, віросповідання, стану здоров'я, місця проживання відповідно до їх здібностей. 
Вимоги щодо самостійного вивчення навчального матеріалу конкретної дисципліни визначаються навчальною програмою дисципліни, методичними вказівками, інструкціями і завданнями, що містяться у дистанційному курсі.

Лекція - один із видів навчального заняття у дистанційному навчанні, на якому здобувачі вищої освіти отримують аудіовізуальну інформацію лекційного характеру через засоби телекомунікаційного зв'язку як у синхронному режимі, коли вони можуть отримувати інформацію від лектора і ставити йому запитання у реальному вимірі часу, так i в асинхронному, коли вони отримують аудіовізуальний запис лекційного матеріалу.

Консультація - це елемент навчального процесу, за яким здобувачі вищої освіти дистанційно отримують відповіді від викладача на конкретні запитання або пояснення певних теоретичних положень чи аспектів їх практичного застосування.

Семінар - це навчальне заняття, що заплановане програмою навчальної дисципліни, під час якого відбувається обговорення вивченої теми зі здобувачами вищої освіти.

Дискусія - це навчальне заняття, проведення якого визначається викладачем у зв'язку з необхідністю вирішення поточної проблеми, що виникла у здобувачів вищої освіти в ході навчання шляхом обговорення ії̈ студентами з викладачем та між собою.

Семінар і дискусія проводяться дистанційно у синхронному режимі (в реальному часі) з використанням телекомунікаційної мережі.

Практичне заняття - це навчальне заняття, під час якого відбувається детальний розгляд здобувачами вищої освіти окремих теоретичних положень навчальної дисципліни та формуються вміння і навички їхнього практичного застосування шляхом індивідуального виконання ними завдань, що сформульовані у дистанційному курсі.

Лабораторне заняття - форма навчального заняття, яка передбачає, що здобувачів вищої освіти особисто проводять натурні або імітаційні експерименти чи досліди 3 метою практичного підтвердження окремих теоретичних положень конкретної навчальної дисципліни, набувають практичних навичок роботи 3 лабораторним устаткуванням, обладнанням, вимірювальною апаратурою, обчислювальною технікою, методикою експериментальних досліджень у конкретній предметній галузі.

Сучасне суспільство поставило перед вищою школою всіх країн нове глобальне завдання - необхідність забезпечення доступу до вищої освіти все більш широких верств суспільства, оскільки для будь-якої країни ступінь іiі економічного і технологічного розвитку, добробуту суспільства пропорційні середньому рівню знань, умінь, навичок і кваліфікацій їі активного населення [1]. Сучасному суспільству потрібна масова якісна освіта, яка спроможна забезпечити вимоги до споживача та виробника матеріальних і духовних благ.

На сьогодні існує багато підходів до визначення поняття «дистанційне навчання». Це поняття було сформульоване такими вченими, як М. Томпсон, М. Мур, А. Кларк, і Д. Кіган. Кожен із цих авторів підкреслював окремий аспект цього методу [2]. 
Основними принципами системи дистанційної освіти $€$ гнучкість, модульність, динамічність, адаптивність, неперервність, креативність і відкритість. Вона базується переважно на самостійному отриманні необхідного обсягу знань і передбачає поєднання широкого спектру традиційних і новітніх інформаційних технологій. Використання цих технологій дозволяє здобувачам вищої освіти поповнити перелік умінь і навичок, які в подальшому визначать їх успішність у будь-якій сфері діяльності. До них відносять такі вміння і навички: самостійно планувати свою діяльність; приймати рішення, робити вибір і нести за нього відповідальність; працювати в інформаційному просторі (відбирати необхідну інформацію, структурувати i використовувати для прийняття рішення); подавати результати діяльності 3 використанням інформаційних технологій; навички самоосвіти.

Технологія дистанційного навчання в університетах використовується як в очній, так і в заочній формі навчання, що сприяє покращенню якості та доступності освіти. Дистанційне навчання (Distance Learning, Distance Education) - це така форма організації освітнього процесу, основою якої є самостійна робота людини, яка навчається. Це дає змогу навчатися у зручний для людини час та у віддаленому від викладача місці (тому дистанційне). Названий тип навчання дає змогу отримати освіту широкому колу людей, які мають певні обмеження задля очного навчання: йдеться про працюючих, військових строкової служби, інвалідів, в’язнів та ін. Значна кількість людей має вікові обмеження, через що цю форму навчання інколи називають освітою дорослих (adult education). Іншими словами, дистанційне навчання передбачає таку організацію навчального процесу, коли здобувач вищої освіти навчається самостійно за розробленою викладачем програмою і віддалений від нього у просторі чи в часі, однак може вести діалог із ним за допомогою засобів телекомунікації [1].

Останнім часом Internet завойовує все більшу популярність у вивченні тих чи інших дисциплін поряд із традиційними формами навчання. Це пов'язане із трьома обставинами: технічний розвиток Internet-технологій, що дозволяють більш дешевими та зручними засобами реалізувати будь-яку навчальну модель; простота під'єднання до мережі Internet та низька вартість під'єднання.

Із широкими можливостями дистанційного навчання можна ознайомитися на рисунку 1. 


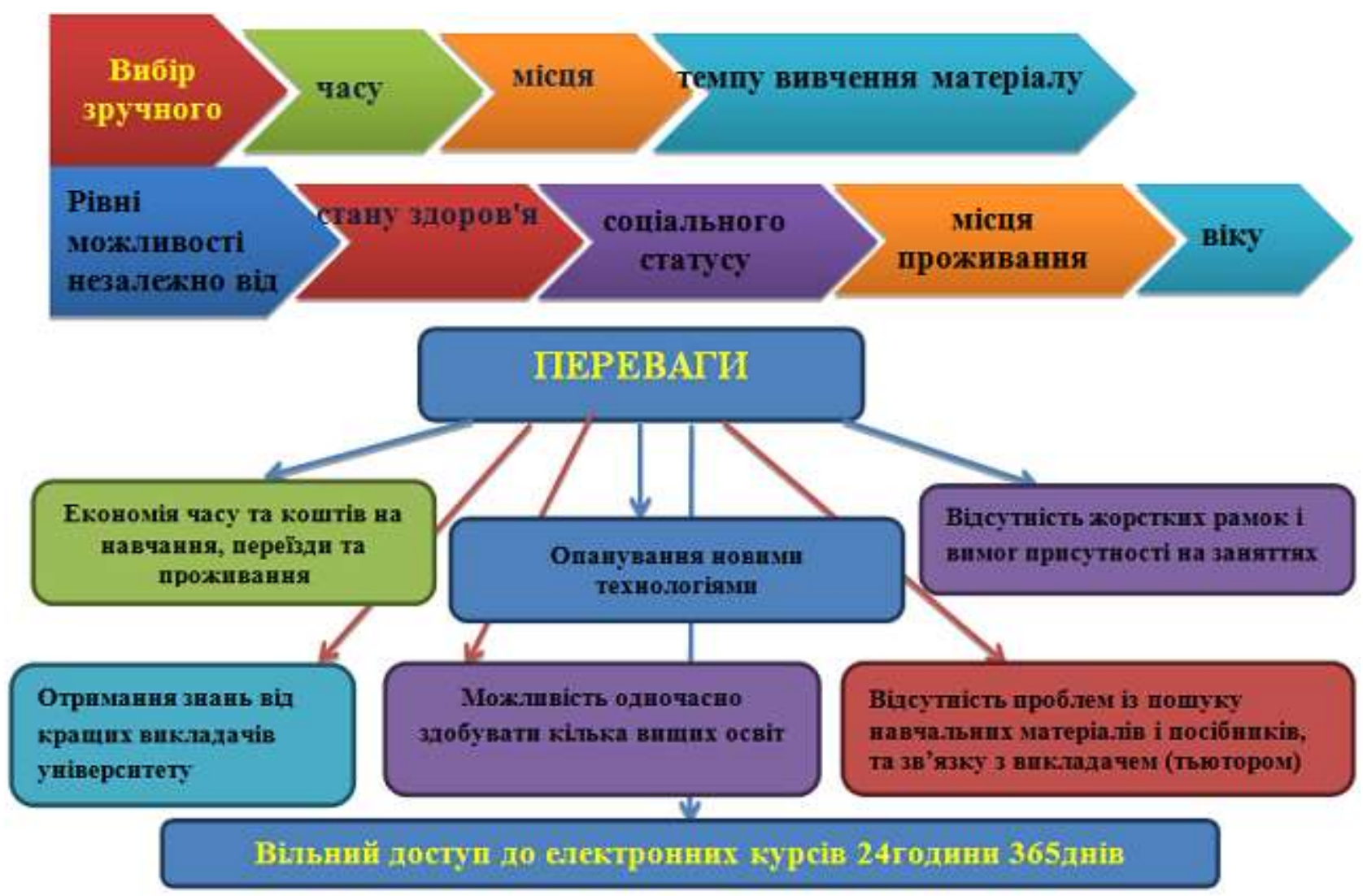

Рис. 1. Можливості дистанційного навчання

Основною передумовою виникнення дистанційної форми освіти $\epsilon$ підвищення технологічного розвитку, який сприяє поліпшенню соціальноекономічного стану. Зокрема, В. Кремень переконаний, що дистанційна форма освіти - реакція на зовнішні зміни, які відбуваються у світі (об'єктивні тенденції глобалізації світу, підвищення динаміки його соціально-економічного розвитку, бурхливий розвиток інформаційних і телекомунікаційних технологій) [3].

У результаті проведеного дослідження виділено переваги і недоліки дистанційного навчання здобувачів вищої освіти:

\section{Переваги:}

- можливість до засвоєння максимального обсягу необхідних знань, які не можуть бути включені у звичні аудиторні форми;

- розширення кола осіб, здатних отримати необхідну вищу освіту, а саме осіб з особливими потребами в розвитку;

- здатність до навчання осіб у віддалених важкодоступних регіонах за допомогою баз необхідних рефератів;

- здатність до централізації освітнього процесу різних регіонів;

- стирання кордонів між очною та заочною формами навчання;

- задоволення клієнтів в отриманні підготовки в комфортних для них умовах.

Недоліки:

- недостатній контроль над засвоєнням здобувачами вищої освіти одержуваних знань;

- «теоретизація» навчання, зведення навчального процесу до механістичних прийомів і методів; 
- неможливість формування повного уявлення про зміст навчальної дисципліни,

- можливість хакерського вторгнення в електронну базу даних.

Було зроблено такі висновки:

1. Необхідна зміна структури дистанційного навчання для досягнення іiі більшої ефективності.

2. Введення електронної версії рейтингової системи.

3. Застосування практичних відеопосібників під час проведення теоретичного курсу.

4. Посилення захисту і контролю над головними комп'ютерними базами й електронними центрами.

У кінцевому результаті успішне вирішення проблеми удосконалення дистанційної освіти в Україні сприятиме підвищенню якості і рівня доступності вищої освіти, інтеграції національної системи освіти в наукову, виробничу, соціально-суспільну та культурно-інформаційну інфраструктуру світового співтовариства. В умовах пандемій, стихійних лих та інших катаклізмів дистанційна освіта вже займає належне їй місце, іiі використовують в усіх закладах освіти. Тому треба спрямувати всі зусилля на ії підтримку та розвиток, постійно дбати про ії вдосконалення.

\section{Список літератури:}

1. Триндаде А.Р. Информационные и коммуникационные технологии и развитие человеческих ресурсов. Дистанционное образование. 2000. № 2. C. 5-9.

2. Хассон В. Дж., Вотермен Е. К. Критерії якості дистанційної освіти. Вища освіта. 2004. № 1. С. 92-99.

3. Татарчук Г. М. Институционализация дистанционного обучения: социологический аспект. Образование. 2000. № 1. С. 63-72. 


\title{
ПРОБЛЕМИ ФОРМУВАННЯ ПИСЕМНОГО МОВЛЕННЯ У ДІТЕЙ ІЗ ТЯЖКИМИ ВАДАМИ МОВЛЕННЯ
}

\author{
Журба Тетяна Анатоліївна, \\ вчитель початкових класів вищої кваліфікаційної категорії \\ Новоушицької спеціальної школи
}

Закон України “Про освіту” визначає всебічний розвиток дитини як особистості, розкриття ii талантів, розумових, інтелектуальних, культурних здібностей та потенціалу як основну мету сучасної освіти [1]. Важливу роль на шляху досягнення цієї мети відведено початковій ланці освіти, адже саме на цьому етапі навчання в учнів формуються основи наукового світорозуміння, визначаються способи навчальної діяльності. У зв'язку з цим, період навчання школярів у початкових класах $є$ фундаментом для засвоєння в наступні роки широкого спектру наукових знань та навичок, застосування їх на практиці.

Згідно 3 Національною доктриною розвитку освіти у XXI столітті, вдосконалення системи освіти й виховання у відповідності до принципів гуманізації та індивідуалізації передбачає максимальне врахування особистісних та психофізичних особливостей дітей й створення таких умов освіти, які б сприяли своєчасному й повноцінному розвитку всіх сторін особистості дитини та iii успішному навчанню [2]. Отже, актуальною проблемою української педагогічної теорії і практики $є$ реалізація прав дітей 3 порушеннями у психофізичному розвитку, у тому числі й дітей 3 тяжкими порушеннями мовлення.

Особливістю дітей з тяжкими порушеннями мовлення є стійке комплексне порушення мовлення, яке, як правило, супроводжується неврологічною та психопатологічною симптоматикою, а також різними відхиленнями психічної діяльності. Вирішення практичних питань мовленнєвого розвитку дітей 3 тяжкими порушеннями мовлення грунтується на Конституції України (254к/96ВР), законі України "Про державні соціальні стандарти і державні соціальні гарантії" (2017-14) та інших нормативно-правових актах, що регулюють правовідносини у цій сфері, та міжнародних договорах України, згода на обов'язковість яких надана Верховною Радою України [3, с.12].

Виявлення та усунення різних порушень мовлення необхідно проводити на ранніх етапах навчання та виховання, оскільки правильне мовлення $є$ однією 3 важливих передумов подальшого повноцінного розвитку дитини та процесу навчання в цілому. На сьогодні особливого значення набуває пошук інноваційних шляхів формування писемного мовлення у дітей 3 тяжкими порушеннями мовлення, що реалізували б напрями, визначені в " Концепції лінгвістичної підготовки аномальних дітей дошкільного навчання" [4].

Інтенсифікація навчально-виховного процесу дітей 3 тяжкими вадами мовлення вимагає впровадження низки заходів щодо вдосконалення системи їх навчання і виховання у відповідності до сучасних умов розбудови нашої 
держави. Вирішення цієї важливої психолого-педагогічної проблеми $\epsilon$ надзвичайно актуальним завданням і у спеціальній школі для дітей із тяжкими вадами мовлення, де рівень засвоєння знань значною мірою обумовлює якісне оволодіння усіма навчальними дисциплінами, збагачення знаннями про оточуючу дійсність [5]. Неповноцінна або часткова мовленнєва діяльність негативно впливає на формування у дітей із тяжкими вадами мовлення інтелектуальних та сенсорних навичок, що пояснюється взаємозв'язком мовленнєвих порушень з іншими сторонами їх психічного розвитку.

Діти з тяжкими вадами мовлення у цілому мають повноцінні передумови для оволодіння мовленнєвими навичками, але первинний вроджений недорозвиток їхнього мовлення зумовлює деякі специфічні особливості мислення, або ж відставання в розвитку образного мислення. Такі діти не можуть самостійно оволодіти аналізом, синтезом, порівнянням, їм властива ригідність мислення. Недостатність словотворчих умінь і навичок у дітей даної категорії, на жаль, констатується лише супутно, а несформованість граматичних процесів як операцій з мовними знаками розглядається лише в деяких дослідженнях (Б. Гриншпун, С. Соботович, В. Ковшикова та ін.) [6].

Мовленнєва діяльність людини є системою, що включає чотири види мовленнєвих дій: розмова (власне, експресивна діяльність), слухання (імпресивна мова), письмо та читання. Писемне мовлення являє собою не тільки фіксацію змісту мовлення за допомогою спеціальних графічних знаків, але й обов'язково передбачає передачу висловлювання за допомогою писемного тексту, тобто породження мовлення на письмі. Процес письма відноситься до найбільш складних усвідомлених форм мовної діяльності. Саме тому однією 3 основних задач корекційно-попереджувального навчання дітей молодшого шкільного віку є оволодіння письмовим мовленням [7].

Для формування автоматизованих навичок письма неабияке значення мають такі передумови, як сформованість усного мовлення, вільне володіння ним, здатність проводити аналіз і синтез слова; сформованість просторового сприйняття і просторових уявлень, а саме: орієнтування в поняттях "ліворуч", "праворуч", у схемі власного тіла і у просторі; розвиток тонкокоординованих рухів рук; сформованість зорово-моторних (здійснення зв'язку між тим, що бачить, i тим, що записує) і слухо-моторних (зв'язок між тим, що чує, і тим, що записує) координацій; сформованість довільної діяльності, вміння регулювати власні дії, застосовувати вольові зусилля [7].

Саме у процесі вивчення рідної мови у дітей із тяжкими вадами мовлення починають формуватися спеціальні мовні знання, поповнюється їхній словниковий запас та виробляються навички усного й писемного мовлення. При розробці системи педагогічно-методичної роботи, спрямованої на формування дитячого мовлення в умовах глибокого його недорозвинення, принципове значення має врахування закономірностей розвитку мовлення дітей, які нормально говорять, що дозволяє визначити вимоги до розвитку тих або інших рівнів мовленнєвої діяльності на різних етапах iï формування. Необхідно також враховувати рівень розвитку патологічного мовлення, його особливості й потенційні можливості оволодіння дітьми мовою у процесі корекційного впливу. 
Навчання правильному мовленню дітей із тяжкими вадами мовлення носить практичну мовленнєву спрямованість. Це означає, що головним завданням $\epsilon$ формування мовленнєвих умінь і навичок у процесі мовленнєвої діяльності. 3 метою розвитку таких умінь і навичок у початкових класах школярі отримують елементарні уявлення (спочатку в практичному плані) про засоби мови (фонетичні, лексичні, граматичні), які необхідні для мовленнєвого спілкування. 3 цією ж метою учнями засвоюються мовні (лінгвістичні) знання, виробляються уміння й навички, що сприяють оволодінню мовленням [8].

Традиційно вважається, що навчання усному мовленню прямо пов'язане із розвитком писемного мовлення. Під формуваннями писемного мовлення розуміють процес формування в учнів умінь і навичок побудови писемного висловлювання, викладення думок у писемній формі. Метою підготовчого періоду до навчання писемному мовленню є формування у дітей елементарних технічних і графічних умінь. У ході підготовчого періоду діти мають засвоїти та вдосконалити вміння 3 написання певних графічних форм, їх назви, які $\epsilon$ складовими навичками письма.

В ході підготовки дітей до оволодіння письмом, педагог зобов'язаний враховувати те, що такі діти не вміють активно спостерігати та аналізувати певне графічне зображення, а відповідно і не можуть самостійно його відтворити. Особливо це стосується дітей з тяжкими вадами мовлення, у яких саме ця риса гальмується. Діти 3 тяжкими вадами мовлення часто відволікаються, забувають, 3 чого почали, а відтак швидко втрачають інтерес до цього заняття, це все $\epsilon$ прямим наслідком різного роду відхилень психічної діяльності та психоневрологічних особливостей індивідуума.

Основний метод підготовки дитини 3 тяжкими порушеннями мовлення до оволодіння самостійним писемним мовленням - гра, оскільки саме гра сприяє активізації розумової діяльності та залученості до навчального процесу в цілому. Учителі та логопеди можуть використовувати різні ігрові методи навчання, і це можуть бути ігри-заняття, чи ж то ігри-вправи.

Таким чином, взаємозв'язки і взаємов'язаність розвитку усного і писемного мовлення та його механізми в природньому їх розвитку зумовлюють дотримання визначеної послідовності у формуванні мовленнєвої готовності дітей з тяжкими вадами мовлення. Наявність у молодших школярів із тяжкими вадами мовлення певних мовленнєвих та психофізіологічних порушень викликає специфічні утруднення, які гальмують оволодіння знаннями 3 мови, стають причиною неграмотності таких учнів. Діти 3 тяжкими вадами мовлення потребують особливо продуманої системи подання нового матеріалу. На сьогодні критично важливим стає пошук нових обхідних шляхів, які мають забезпечити повноцінне сприймання й подальше відтворення здобутих знань.

Отже, формування мовленнєвої готовності до оволодіння писемним мовленням дітей із тяжкими вадами мовлення залежить від здатності розуміти лексичні й граматично-семантичні значення мовних одиниць, що забезпечується в умовах спеціально організованого, насиченого мовленнєвого середовища. 


\section{Список літератури}

1. Закон України Про освіту (Відомості Верховної Ради (ВВР), 2017, № 38-39, ст.380) [Електронний ресурс] . - Режим доступу: https://zakon.rada.gov.ua/laws/show/2145-19\#Text

2. Указ Президента України № 347/2002 від 17.04.02 року «Про Національну доктрину розвитку освіти». [Електронний ресурс] . - Режим доступу: http://osvita.ua/legislation/other/2827/

3. Э.Э. Фигередо. Психолого-педагогическая характеристика дошкольников с ОНР: Автореферат. - М.: Педагогика, 1989. - 17

4. Н.О. Никашина. Логопедическая помощь учащимся с речевым недоразвитием // Недостатки речи у учащихся начальных классов массовой школы. - М.: Просвещение, 1965. - С.25-29

5. В.І. Захарченко. Мовленнєве спілкування у грі. / В.І. Захарченко // Дошкільне виховання, № 12, 2000. - С.35-39.

6. О.В. Ревуцька. Збагачення лексичного запасу молодших школярів із тяжкими порушеннями мовлення у процесі засвоєння словотворчих засобів. Монографія, 2007, $181 \mathrm{c.}$

7. К.В. Комаров. Методика обучения русскому языку в школе для детей с тяжелыми нарушениями речи. - М.: Просвещение, 1982. - 160 с.

8. В.І. Захарченко. Мовленнєве спілкування у грі. / В.І. Захарченко // Дошкільне виховання, № 12, 2000. - С.35-39. 


\section{ТЕОРЕТИЧНІ ОСНОВИ РОЗУМІННЯ ПОНЯТТЯ ФОЛЬКЛОРНОГО СИМВОЛУ В ПОЧАТКОВІЙ ШКОЛІ}

\section{Здіховська Тетяна Вікторівна,}

доцент,

Волинський національний університет імені Лесі Українки

\section{Свиріпа Ірина Андріївна,} магістр,

Волинський національний університет імені Лесі Українки

Українська система символічного відображення світу належить до найдавніших і найбагатших систем традиційної культури, бо це водночас інструмент пізнання, метод вираження реальності та прихованих скарбів духовності. У світі символів людина живе з прадавніх, доісторичних часів - із періоду пізнього палеоліту, але i до наших днів проблема походження, виникнення символу достатньо в світовій теоретичній думці не досліджена.

Теорії символу беруть початок від античності. Символ досліджували ще Арістотель і Платон, І. Кант і Г.В. Гегель. Відтоді й донині погляди на його природу, функції, роль і місце в житті людей досить суперечливі, неоднозначні. В українській теоретичній думці проблемою символіки займалися Г. Сковорода, М. Костомаров, О. Потебня.

Вивчення української фольклорної символіки розпочалося в першій половині XIX ст. Цікаві спостереження з цього погляду зустрічаємо в працях М. Максимовича, I. Срезневського, О. Бодянського та ін. Найпомітнішими дослідженнями зазначеної проблеми в той період стали магістерська дисертація М.Костомарова "Про історичне значення руської народної поезіі” (1843) та монографія О. Потебні “Про деякі символи в слов'янській народній поезії” (1860).

Пізнання символіки, вивчення її дітьми - органічна потреба в задоволенні духовних, культурних запитів, вдосконаленні внутрішнього світу й приведенні його до гармонії із зовнішнім. Тому осмислення символів, фольклорної символіки зокрема, на нашу думку, допоможе врятувати цивілізацію від морального спустошення і деградації.

Проблема походження, виникнення символу достатньо у світовій теоретичній думці не досліджена. Дехто з учених, скажімо, вважає, що символізм виник тоді, коли занепадали первісні релігії. Зрештою, кожен жест, звук, слово були в певному розумінні символічними й нерідко залишаються такими й досі. Слово «символ» у сучасної людини викликає не тільки ряд абстрактних понять чи конкретних уявлень, асоціацій, образів, а й відчуття магічного, таємничого, загадкового. У перекладі з грецької слово символ означає «з'єднувати», «зливати», «зв’язувати»; «знак, пізнавальна ознака» [2, с. 217]. 
С. Я. Срмоленко розуміє народнопісенний символ із погляду лінгвофольклористики як „слово, яке завдяки традиційному вживанню в фольклорних формулах, завдяки стійким асоціаціям набуває додаткового узагальненого значення, додаткової емоційної оцінки. Зміст його прочитується однозначно незалежно від контексту" [3, с. 21].

Найвиразніша риса фольклорного словника - символічність і абстрактність. Лексеми, що входять до цього словника, майже втрачають номінативне значення і набувають нового змісту в межах іншої системи, пов'язаної безпосередньо 3 картиною світу. Наприклад, хата, дiм - не тільки позначають житло, й центр свого світу, замкнений, захищений простір, що забезпечує при цьому вихід назовні й контакти із зовнішнім світом. Колодязь - не лише водний резервуар, а межа свого й чужого світу. Б. М. Путілов зазначав, що фольклорна картина світу створена внаслідок семантичного перекодування нефольклорного матеріалу (міфологічного й етнографічного) через систему фольклорних кодів шляхом узагальнення, типізації і перекладу культурних смислів на мову поетичної символіки [6, с. 122].

В українському пісенному фольклорі образи-символи - це особливий спосіб відтворення дійсності. Слова-символи пісенного фольклору відтворюють різні етапи формування народнопоетичного сприйняття категорії простору. У пісенних текстах символи корелюють із контекстом ритуальної, етнографічної української культури. На думку В. В. Кононенка, образно-символічного змісту набувають передовсім назви на позначення явищ і предметів повсякденного життя, що відбивають прикмети навколишнього середовища, побуту, культури, традиції та звичаї. Показово, що носіями відповідних символічних категорій часто виступають назви не абстрактних понять, а реалій, які повсякчас супроводжують людину [5, с. 3-5].

Пізнання символіки якнайширшим колом читачів - органічна потреба в задоволенні духовних, культурних запитів, вдосконаленні внутрішнього світу й приведення його до гармонії із зовнішнім.

Найбільш багата і поетична фольклорна символіка, що являє собою сукупність, систему особливих умовних образів культури, які відображають погляди українців на світ, об'єктивований у їхніх ідеалах та уявленнях.

Обряди і традиції, пов'язані з деревами, травами, зіллям і квітами, доносять відгомін язичницьких уявлень наших предків про навколишню природу i базуються як на реальних, так і на уявних властивостях рослин.

Особливе місце займали рослини-символи. Кожна рослинка мала багато народних назв, часто дуже влучних, поетичних. Багато 3 тих «імен» $\mathrm{i}$ тих спостережень чи легенд, що за ними стояли, забулося. Усе мало значення: від вікового дерева, до билинки під ногами. До всього зверталися у замовляннях, про все складали легенди, пісні, казки. Не все збереглося у століттях. Ось, наприклад, вишня - одна 3 корисних і поширених рослин, одне 3 найстаріших дерев в Україні. Це дерево є символом матері, рідної землі, дівчини - нареченої [1, с. 21].

У фольклорній творчості нашого народу відбита шана до рослини, замилування нею. Іноді навіть гумористичні інтонації звучать, як-от у загадках: 
«Чого ти став та дивишся? Зірви мене - поживишся!»; «Сиджу на дереві кругла, як куля, червона, як кров, добра, як мед».

Спостереження над життям улюбленого в народі дерева породили прикмети: «Якщо з вишні листя опаде до 14 жовтня, до Покрови, зима буде тепла, якщо ж до цього таки дня вишня зелена, зима буде люта»; «Поки листя 3 вишень не обсиплеться, скільки б снігу не випало - ненадовго: відлига зжене» $[4$, c. 47].

Вишня у народній творчості переважно образ жіночий. 3 нею насамперед асоціюється почуттєвий світ дівчини, і взагалі тривожна, очікувальна й неповторна пора дівування. 3 вишнею порівнюється краса дівчини, ï молодість незайманість: Ой, вишенька, черешенька, вишенька, вишенька, Мушу я придивитися, чи ти молоденька.

Вишня кучерява як і приворотний знак у коханні: Ой вишенька, черешенька, Зверху кучерява, Дівчинонька козаченька Та й причарувала.

3 вишнею пов'язували і повір'я. Наприклад, в деяких місцевостях України дівчата з метою гадання про заміжжя пересаджували взимку молоді вишеньки в діжки і тримали їх у теплій хаті.

Прекрасне дерево символізує материнство: Ой у саду вишня ягідки зродила, Я з тобою, мій миленький, діточок сплодила.

Сирітство: Осталась сирітонька, Як вишенька зелененька.

При згадці про вишню на пам'ять одразу ж приходить така близька і люба серцю, кожному знайома поезія Тараса Шевченка: Садок вишневий коло хати, Хрущі над вишнями гудуть.

Ознайомлення учнів 3 народнопоетичними символами на уроках у початковій школі дає змогу розширювати та поглиблювати знання школярів про рідну країну, природу, злити в єдиний процес пізнавальну та виховну функції уроків читання.

Вивчення у школі народних символів, що втілюють у собі глибоку духовність, культурно-історичну пам'ять, $є$ одним з етапів прилучення школярів до глибин народної мудрості. Синівські почуття любові до рідного народу, отчого краю споконвіку виховували в дітей символи - обереги етнічної пам'яті (калина в лузі, верба над ставом, тополя край дороги і т.д.), які в своїй сукупності символізують рідний край, землю, природу. Вони зігрівають серце, збагачують душу, надихають на творчу працю і подвиги. На жаль, підростаюче покоління мало знає про народні символи. А тому доброю нагодою у цьому плані стануть уроки літературного читання.

Організовуючи роботу над художнім твором, учитель детально продумує кожний етап уроку, кожний вид роботи. Знаючи, що для правильного сприймання змісту школярам необхідно мати певний запас життєвих уявлень, учитель веде підготовчу роботу. Крім того, у мовлення учнів вводяться нові слова і вислови з тексту. Зауважимо, що не слід виходити за межі твору; нове тлумачення роз'яснювати, не відступаючи від змісту. Нехай учень усвідомить одну сторону поняття. Іншим разом осмислить щось нове в ньому та поступово збагне повністю. 
Основний зміст творів, які дають відомості про той чи інший символ, розкривається в народних і літературних матеріалах-оповіданнях, віршах, легендах, піснях, переказах, прислів'ях, притчах, казках.

Робота над розвитком мовлення учнів - невід'ємна частина кожного етапу уроку читання. Скажімо, під час читання тексту вчителем учні отримують завдання стежити за мовою твору, виявляти незрозумілі слова і вислови, а потім брати посильну участь у розкритті їх значення. Під час аналізу змісту оповідань шляхом зіставлення близьких або протилежних за значенням слів словотворчого аналізу, виявляється смислова роль слова. Відповідаючи на запитання вчителя та переказуючи зміст твору, учні закріплюють нові слова 3 тим, щоб використовувати у власній мовній практиці.

Велику можливість збагатити знання дають вірші. Саме через них можна ознайомити учнів з рослинами-символами. Мова вірша ритмічно організована, більш емоційна й експресивна, ніж мова прози. Підготовка й читання поетичного твору мають певні свої закономірності.

Найперше, на що звертається увага дітей, - це ритмічність мови та гармонія звуків. Першокласникам важко зрозуміти усю складність і особливість ліричних творів, проте педагог має в доступній формі розкрити їм, що якраз у ліриці поет прагне показати красу української землі, природи.

Звичайно, у таких віршах відображені прості картини природи, які не завжди перегукуються 3 настроєм дітей. I все ж у переважній більшості - це барвисті й емоційні мініатюри, що можуть бути зразками в роботі над виразним читанням пейзажної лірики.

Під час бесіди за змістом легенди варто звернути увагу школярів на ту частину твору, яка розповідає про походження символу. Так, при читанні легенди «Тополя, Гранат і Кипарис» саме з такого абзацу діти дізнаються, що тополя - символ дівочої краси, символ сумної дівчини:

Слід відмітити, що багато учнів при завданні пояснити значення слова “символ”, просто перераховують символи. Тому вчитель повинен так пояснити значення слова «символ».

- Які народні символи ви знаєте?

Ознайомлення учнів 3 народнопоетичними символами на уроках у початковій школі дає змогу розширювати та поглиблювати знання школярів про рідну країну, природу, злити в єдиний процес пізнавальну та виховну функції уроків класного читання.

Вивчення у школі народних символів, що втілюють у собі глибоку духовність, культурно-історичну пам'ять, $є$ одним з етапів прилучення школярів до глибин народної мудрості. Синівські почуття любові до рідного народу, отчого краю споконвіку виховували в дітей символи - обереги етнічної пам'яті (калина в лузі, верба над ставом, тополя край дороги і т.д.), які в своїй сукупності символізують рідний край, землю, природу. Вони зігрівають серце, збагачують душу, надихають на творчу працю і подвиги. На жаль, підростаюче покоління мало знає про народні символи. А тому доброю нагодою у цьому плані стануть уроки читання. 
Завдання школи - виховати в дітей органічну потребу в читанні, а учень здатний сприймати те, що веде його в світ пізнання, що цікаве йому. Школяр уважно працюватиме на уроці, якщо вчитель потурбується насамперед про те, щоб він самостійно справлявся із завданнями, які викликали б жваву зміну уявлень, сприяли роз'ясненню понять, відкривали щось нове.

Розвиток мовлення молодих школярів $є$ складовою частиною рідної мови, провідним принципом іiі опанування. На кожному уроці вчитель дбає про збагачення словникового запасу дитини, працює над виробленням уміння вживати слова у правильній граматичній формі, вдосконалює діалогічне мовлення, закладає основи зв'язного монологічного мовлення.

Роботу над символікою тих чи інших рослин доцільно проводити і в позаурочний час, наприклад, під час проведення тематичної екскурсії на лоні природи. Можна запропонувати тему «Ознайомлення учнів зі світом польових квітів і трав». До цієї теми має добре підготуватися сам учитель: знати назви рослин і вміти коротенько розповідати про їх символіку.

Наприклад, демонструючи волошку, вчителька має повідомити іiї літературну назву і місцеву, бо в народі ії інколи називають блаватом:

- На наших полях волошка росте 3 давніх часів, переважно серед озимих культур - пшениці, жита. Це однолітня рослина 3 сухуватим стебельцем. Листочки в неї вузькі, нагадують весельця. Цвіте переважно у червні-липні. Сині волошки - чудові медоноси. Їх також використовують у народній на науковій медицині. Здавна людям волошки до душі, про них складено чимало пісень. Волошками й нині заквітчують традиційні іменні снопи. Наприклад, на Україні був звичай - останній сніп у жнива прикрашали волошками, приносили в хату i ставили на почесне місце. Волошка - це символ простоти і ніжності.

Таким чином, ми знайомимо дітей з символікою квітів і трав, виховуємо любов до природи, своєї місцевості, рідної землі, Батьківщини.

Отже, вчителям початкових класів потрібно вже 3 перших днів ознайомлювати учнів з символами, розповідати, як ставились до них наші предки. I лише тоді діти усвідомлять свою громадянську роль спадкоємців народних цінностей та традицій української культури.

\section{Література:}

1.Берегова О. Символи слов'ян. СПБ. : Диля, 2007. 432 с.

2.Дмитренко М. К. Українська фольклористика : Історія, теорія, практика. Київ : Ред. часопису «Народознавство», 2001. 258 с.

3.Срмоленко С. Я. Нариси з української словесності. К. : Довіра, 1999. 430 с.

4.Кириченко Г. М. Уроки народознавства у початкових класах. Початкова школа. 2013. 6. С. 46-47.

5.Кононенко В. І. Символи української мови. Івано-Франківськ : Плай, 1996. $272 \mathrm{c}$.

6.Символ. Литературный энциклопедический словарь / под общей ред. В. М. Кожевникова, П. А. Николаева. М., 1987. 378 с. 


\title{
УКРАЇНСЬКА ШКОЛА ТА ІНКЛЮЗИВНА ОСВІТА
}

\author{
Оріакхі Сінтія Осасере Олоту, \\ Студентка 3 курсу спеціальності «Початкова освіта» \\ Педагогічного інституту \\ Київського університету імені Бориса Грінченка
}

Характерними рисами глобалізації в галузі освіти є уніфікація знань, загальне прагнення країн світу до досягнення високої якості освіти. Освіта стає ключовою детермінантою економічних результатів та світового потенціалу $[2,161]$.

Актуальність проблеми інклюзивної освіти пов'язана з тим, що число дітей, котрі потребують корекційного навчання, значно росте. На сьогодні в Україні понад 1 млн. таких діток, що становить 12\% від загальної кількості дітей у нашій країні.

Реалії сьогодення вказують на те, що суспільство має нагальну потребу в розвитку інклюзивної освіти, створенні умов для забезпечення доступної та якісної освіти дітям із психофізичними порушеннями. Питання інтегрованого (інклюзивного) навчання та виховання дітей 3 особливими потребами в загальноосвітніх закладах стала предметом вивчення вітчизняними й зарубіжними вченими В. Бондаря, Л. Байди, І. Білозерської, Л. Даниленко, К. Кольченко, А. Колупаєвої, І. Луценко, М. Сварника, Н. Софій, О. Патрикеєвої, П. Таланчука, В. Шинкаренко.

В основу інклюзивної освіти покладена ідеологія, яка виключає будь-яку дискримінацію. Через обмеження у спілкуванні, самообслуговуванні, пересуванні розвиток цих дітей значною мірою залежить від задоволення їхніх потреб іншими людьми, а це становить багатогранний процес соціальнопедагогічної інтеграції та процесу інклюзії, зокрема.

Інклюзивна освіта - це значний крок до визнання поваги до особистості кожної дитини, прийняття іiі індивідуальності й неповторності, забезпечення іï подальшого повноцінного та гідного життя в суспільстві.

Але у наш непростий час важливою, необхідною передумовою забезпечення ефективності навчання дітей у школі є співпраця вчителів, батьків, соціальних педагогів, практичних психологів. На результативність комплексної роботи в класі впливає координованість діяльності усіх членів команди, особливо якщо навчаються діти з інклюзією.

Батьки є безпосередніми учасниками команди супроводу, відповідно вони отримують інформацію про розвиток дитини, іiі здібності та успіхи ніби зсередини. Проте для кращого розуміння не тільки базових, а й специфічних потреб власної дитини відповідно до особливостей іiі розвитку доцільним $\epsilon$ розширення кола спілкування, краща обізнаність батьків [1, с.74] та можливість надання їм більшої дієвої підтримки. Таку допомогу вони можуть отримати у школі.

Інклюзивна освіта у школі дає можливість усім учням у повному обсязі брати участь у житті класу. 
Переваги інклюзивної освіти:

- діти навчаються разом у звичайній школі;

- поліпшується моторний, мовний, соціальний, емоційний розвиток дитини;

- діти отримують можливість жити разом з батьками;

- оволодіння новими вміннями та навичками відбувається функціонально.

- навчання проводиться з орієнтацією на здібності та інтереси дітей;

- у дітей $є$ можливість для налагодження дружніх стосунків з ровесниками;

- діти з особливими потребами отримують ефективну освіту, щоб жити повноцінним життям.

В Україні система інклюзивної освіти знаходиться на початковому етапі розвитку. У шкільних класах навчається до 30 учнів, троє з яких можуть бути дітьми 3 особливими освітніми потребами. За кожним таким учнем має бути закріплено асистента, основним завданням якого $є$ допомагати як своєму підопічному під час та поза уроками.

«Вивести на високий рівень» цю систему можна лише за умови вирішення фінансових і кадрових, а також подолання соціальних проблем.

Однак, школам не вистачає ресурсів і кваліфікованих спеціалістів.

На підставі зазначеного можна зробити висновок, що важливо розвивати й удосконалювати інклюзивне навчання, домагатися забезпечення умов, які передбачають задоволення індивідуальних потреб осіб із порушенням здоров'я, іншими словами, надання потенціалів для навчання подібних категорій громадян у загальноосвітніх навчальних закладах. Ми зобов'язані створити таку інфраструктуру освіти, такі умови життя, щоб учень із вадами психофізичного розвитку не відчував неповноцінності й зумів задовольнити свої потреби.

Найголовніше - пам'ятайте, що запорука ефективної організації інклюзивного навчання, як і будь-якої корисної та нової справи, - співпраця та партнерство із усіма долученими до неї людьми.

\section{Список літератури:}

1. Кучманіч І. Класифікація особливих потреб дитини в контексті системного підходу [Електронний ресурс] / І. Кучманич, Л. Опанасенко // Проблеми сучасної психології : електронне наукове фахове видання. - Електронні дані. [Кам'янець-Подільський : Кам'янець-Подільськ. нац. ун-т ім. Івана Огієнка, Ін-т психології ім. Г.С. Костюка НАПН України : Аксіома, 2018] . - No 42. - Режим доступу: http://journals.uran.ua/index.php/2227-6246/article/view/156442/155808.

2. Супрун Д. М. Management - a component of psychologists' professional training (Менеджмент - складова професійної підготовки психологів). Навчально-методичний посібник для студентів, слухачів магістратури та практикуючих психологів. Київ, 2019. 390 с. 


\title{
ОСОБЛИВОСТІ ЗАБЕЗПЕЧЕННЯ ЯКОСТІ МЕДИЧНОЇ ОСВІТИ
}

\author{
Радзієвська Ірина Володимирівна \\ кандидат педагогічних наук \\ Черкаська медична академія
}

Розбудова незалежної Української держави спонукала до нового бачення розвитку ії інтелектуального уособлення та потенціалу, викликала і прискорила значні зміни в суспільному житті, що, в свою чергу, актуалізувало складні психолого-педагогічні проблеми і чинники розвитку всієї національної системи освіти. Ця система стає камертоном становлення держави в XXI сторіччі. Переглядаються та переосмислюються фундаментальні складові освіти: освітні та науково-методичні засади, організаційна структура управління тощо.

Науковці розглядають сучасне суспільство в якому знання, рівень інтелектуального розвитку його членів стає стратегічним ресурсом, важливим фактором розвитку економіки, надає новий статус освіті і пред'являє до неї нові вимоги. Основною умовою здійснення професійної світи студентів $\epsilon$ iї безперервність та послідовність проведення після одержання потрібного обсягу практичних знань, умінь та навичок відповідно до різних освітніх рівнів. Метою професійної освіти є: закріплення теоретичних знань на основі практичного навчання; оволодіння сучасними методами і формами надання медичної допомоги; освоєння нових технологій; формування професійних умінь i навичок для прийняття самостійних рішень; виховання потреби у систематичному оновленні своїх знань для їх практичного застосування; психологічна адаптація до конкретних умов фахової діяльності.

Велика увага в закладах вищої медичної освіти приділяється також змісту освіти та засобам навчання. Зміст освіти відображено у державних стандартах освіти та освітніх програмах, що освітаннім часом інтенсивно впроваджуються у освітній процес освітніх закладів, на їх основі розробляються навчальні програми та науково-методичне забезпечення освітнього процесу (засоби навчання).

Засоби навчання - це різноманітні матеріали і знаряддя освітнього процесу, завдяки яким більш успішно і за коротший час досягаються визначені цілі та програмні результати навчання [1]. До засобів навчання належать: підручники, навчальні посібники, дидактичні матеріали, технічні засоби (ТЗН), обладнання, навчальні кабінети, лабораторії, ЕОМ, засоби масової комунікації [2]. Засобами навчання можуть також слугувати реальні об'єкти та споруди. Дидактичні засоби, як і методи, форми, є частиною педагогічної системи. Вони виконують такі основні функції: інформаційну, засвоєння нового матеріалу, контрольну. Вибір засобів навчання залежить від дидактичної концепції, мети, змісту, методів і умов навчального процесу. Тобто, ми говоримо про матеріальнотехнічну базу закладу освіти та науково-методичне забезпечення освітнього процесу: відповідність матеріально-технічної бази вимогам освітньої програми і 
динаміка ії оновлення; забезпечення нових технологій навчання технічними засобами; рівень використання матеріальної бази в освітньому процесі і рівень забезпечення навчально-лабораторним оснащенням; наявність інноваційного обладнання та інших технічних засобів, що створюються у закладі освіти та використовуються в підготовці спеціалістів; взаємодією випускових кафедр 3 закладами охорони здоров'я, організаціями, установами і використання їх баз та кадрового потенціалу для підготовки фахівців.

Одним 3 найважливіших компонентів освітнього процесу постають методи навчання. Без відповідних методів діяльності неможливо реалізувати мету i завдання навчання, досягнути засвоєння здобувачами певного змісту навчального матеріалу: методи організації і здійснення пізнавальної діяльності; методи стимулювання і мотивації; методи контролю і самоконтролю за ефективністю навчально-пізнавальної діяльності.

Основними формами навчання у вищих медичних закладах освіти є лекції, семінарські заняття, лабораторні заняття, практичні заняття (доклінічна, клінічна (підсумкова та переддипломна практики); додаткові форми - факультативні заняття, гурткова, наково-пошукова, дослідницька, секційна робота, різноманітні конкурси професійної майстерності, олімпіади, спортивні змагання тощо.

Освіта в своїй якісній характеристиці - це не тільки цінність, система чи процес [3]. Це ще й результат, фіксуючий факт присвоєння державою, суспільством та особистістю всіх тих цінностей, які народжується в процесі освітньої діяльності, які важливі для економічного, морального, інтелектуального стану «споживачів продукції» освітньої сфери - держави, суспільства, кожної людини, всієї цивілізації в цілому.

Останнім часом також склалось особливе розуміння вітчизняної системи оцінки якості освіти. Оцінка якості розглядається як сукупність організаційних і функціональних структур, що забезпечують засновану на єдиній концептуальнометодологічній базі оцінку освітніх досягнень і виявлення чинників, що впливають на програмні результати навчання.

В контексті проблеми забезпечення якості освіти цілком обгрунтовано виникає проблема управління якістю освіти. Створення нової моделі сталого розвитку держави має будуватися 3 урахуванням закону випереджаючого розвитку якості освітніх систем і якості управління ними. Необхідність створення загальнодержавної системи якості освіти підтверджується вітчизняним і зарубіжним досвідом.

До основних освітніх тенденцій, що створені в останнє десятиліття в галузі якості освіти, можна віднести наступні:

1) змінилося розуміння якості освіти;

2) проблеми управління якістю освіти та його забезпечення розглядаються в комплексі;

3) розвиваються нові методики і засоби оцінки якості освіти;

4) використовуються багаторівневе системне моделювання при плануванні досліджень якості освіти та багатоаспектний моніторинг при аналізі результатів; 
5) при постановці освітніх цілей і оцінці результатів більш широко розуміються освітні досягнення, які розглядаються як компетенції;

6) проводяться широкомасштабні моніторингові дослідження якості освіти на національному та міжнародному рівнях;

7) результати моніторингу якості освіти стають основою для прийняття управлінських рішень.

У вищих медичних закладах освіти України створені внутрішні системи оцінювання якості освіти. Оцінювання якості освіти передбачає оцінку якості освітніх досягнень студентів та оцінювання якості освітнього процесу в закладі. В сучасному розумінні освітні досягнення складаються 3 предметних знань $\mathrm{i}$ умінь, застосування предметних знань і умінь на практиці; міждисциплінарних умінь; комунікативних умінь; вміння працювати з інформацією за допомогою и комп'ютера; співпрацювати і працювати в групах; вчитися вирішувати виробничі проблеми. Очевидно, що рубіжний та підсумковий контролі знань не забезпечують повну інформацію за перерахованими показниками, оскільки вони оцінюють тільки частину освітніх досягнень студентів - предметні знання та уміння.

При цьому можна застосовувати наступні моніторингові дослідження:

1) порівняння результатів по рокам, можливість змістовної інтерпретації результатів;

2) наявність факторів, що дозволяють пояснювати отримані результати;

3) сумісність системи оцінювання 3 інституційними показниками якості освіти;

4) порівнянність показників; використання взаємодоповнюючих показників;

5) загальні підходи до обробки та аналізу даних.

Тут мова йде про комплекс засобів діяльності в галузі охорони здоров'я на різних вікових етапах. Формування узагальнених засобів діяльності дозволить випускникам застосовувати їх в будь-якій роботі незалежно від спеціалізації. Узагальнені способи діяльності можна назвати компетенціями.

Проблема формування компетенцій, які необхідно формувати в процесі навчання, виникла в освіті не так давно. Крім того, існують різні підходи до визначення поняття «компетенції» і різні підстави для їх кваліфікації [4].

В медичній освіті виділяють наступні основні ознаки функціональної грамотності: готовність підвищити рівень освіти на основі усвідомленого вибору програм загальної та професійної освіти; здатність до вибору професії, орієнтації в політичному житті суспільства, готовність до життя в сучасному світі, орієнтації в його проблемах, цінностях, моральних нормах, розуміння особливостей життя в регіоні, орієнтація в можливостях цьому житті для забезпечення власної безпеки; здатність до комунікативної діяльності в незнайомому середовищі, в тому числі - до спілкування з представниками інших національностей і культур.

Отже, це питання, орієнтація в яких стає обов'язковою умовою для загальної адаптації особистості до соціокультурного середовища.

За думкою учених-педагогів, термін «компетенція» служить для позначення інтеграційних характеристик якості підготовки випускника, категорії результату 
освіти [5]. Під компетентністю розуміється інтегральна характеристика якостей особистості, результат підготовки випускника до діяльності в певних галузях. Розмежовуючи поняття «компетентність» i «компетенція», слід звернути увагу на те, що обидві дефініції включають в себе пізнавальний, мотиваційно-ціннісний i емоційно-вольової компоненти. Разом 3 тим компетентність - категорія ситуативна, оскільки виражається в готовності до здійснення будь-якої діяльності в конкретних професійних ситуаціях.

Отже, інституційна система оцінки якості освіти дозволить оцінити рівень освітніх досягнень здобувачів на різних освітніх ступенях навчання та сформулювати систему оцінювання якості для різних користувачів - студентів, випускників та викладачів вищих медичних закладах освіти.

\section{Література:}

1. Болюбаш Я.Я. Організація навчального процесу у вищих закладах освіти. Київ: ВВП «Компас», 1997.

2. Малежик М.П., Закатнов М.В., Сергієнко В.П. Засоби і технології продукування навчальних інформаційних ресурсів. Науковий часопис НПУ ім. М.П. Драгоманова : збірник наукових праџь. Київ : НПУ ім.. М.П. Драгоманова. №8 (15). 2010. С. 29-35.

3. Гершунский Б.С. Готово ли современное образование ответить на вызовы XXI века? Педагогика. № 10. 2001. С. 3-12.

4. Radziievska I.V. Pedagogical framework of competency oriented education of future medical specialists. Научные труды SWorld. T. 3, № 46. 2017. C. 36-45.

5. Зимняя И.А. Ключевые компетентности как результативно-целевая основа комптентностного подхода в образовании. Авторская версия. Москва : Исследовательский центр проблем качества подготовки специалистов, 2004. $42 \mathrm{c}$. 


\title{
СОЦАЛЬНО-ПЕДАГОГІЧНА РОБОТА ПРАЦІВНИКІВ ОРГАНІВ ПРОБАЦІЇ ЩОДО ВИПРАВЛЕННЯ ТА РЕСОЦАЛІЗАЦІЇ ЗАСУДЖЕНИХ
}

\begin{abstract}
Суліцький Вадим Володимирович
кандидат психологічних наук, доцент Інститут людини Київського університету імені Бориса Грінченка

Іванів Софія-Емілія Андріївна студентка V курсу
\end{abstract} Інститут людини Київського університету імені Бориса Грінченка

За даними прокуратури міста Києва та Київської області, протягом 2020 року обліковано 15,64 тис. кримінальних правопорушень. Серед 4548 виявлених осіб, які вчинили злочини, 21,2\% раніше ставали на злочинний шлях, із яких кожний другий мав незняту або непогашену судимість, 6,4\% вчинили злочин у групі, 6,6\% знаходились у стані алкогольного сп'яніння; 9,5\% - жінки, 1,9\% неповнолітні. Питома вага працездатних осіб, підозрюваних у вчинені злочинів, які на момент учинення злочину не працювали і не навчалися, становила 71,6\%, безробітних - 7,6\% [1]. Порівняльний аналіз наводиться у таблиці. 1. Така ситуація стає загрозливою не тільки для кожного громадянина держави, але й для суспільства загалом, і негативно впливає на внутрішню безпеку держави.

Таблиця 1.

Порівняльний аналіз стану злочинності в Києві та Київській області

\begin{tabular}{|c|c|c|c|}
\hline Показник & $\begin{array}{c}\text { Станом на } \\
01.01 .2020 \text { року }\end{array}$ & $\begin{array}{c}\text { Станом на } \\
01.01 .2021 \text { року }\end{array}$ & Примітка \\
\hline $\begin{array}{c}\text { Порушено } \\
\text { кримінальних } \\
\text { порушень }\end{array}$ & 18671 & 15640 & $<$ на 17,7\% \\
\hline $\begin{array}{c}\text { Видано підозр у } \\
\text { вчиненні злочинів }\end{array}$ & 4548 & 6012 & $>$ на 32,2\% \\
\hline $\begin{array}{c}\text { Кількість осіб, які } \\
\text { вчинили кримінальні } \\
\text { правопорушення віком } \\
\text { від 18 до 35 років }\end{array}$ & 3984 & 4765 & $>$ на 19,6\% \\
\hline $\begin{array}{c}\text { Особи, які вчинили } \\
\text { злочин та мають } \\
\text { базову середню освіту } \\
\text { віком від 18 до 35 } \\
\text { років }\end{array}$ & 3044 & 3988 & $>$ на 31\% \\
\hline
\end{tabular}

Варто зазначити, що розвиток демократичного суспільства дедалі більше залежить від утвердження толерантності, гуманності в стосунках між людьми. 
Соціум став значну увагу приділяти дотриманню прав людини, зокрема в органах пробації, а також проявляти зацікавленість у поверненні до повноцінного життя людей, які вчинили кримінальне порушення та були притягнуті до кримінального покарання, що не пов'язане з позбавленням волі.

Соціально-педагогічна наука розглядає проблеми профілактичної роботи серед осіб, які перебувають у конфлікті з законом і знаходяться на обліку в уповноважених органах філіях Державної установи «Центр пробації», з позицій виправлення та ресоціалізації. Останнім часом чимало науковців зверталися до дослідження цього питання. Так, І. Богатирьов, О. Дука у своїх статтях розглядають питання реформування кримінально-виконавчого кодексу України щодо не пов'язаних 3 позбавленням волі видів покарання; С. Архипова, Ю. Резнік, О.Сушко пропонують заходи щодо вдосконалення діяльності Державної установи «Центр пробації; Ю. Бойко-Бузиль, Н. Максимова, I. Пахомов приділяють увагу соціально-педагогічному супроводженню осіб, які перебувають на обліку в органах пробації; К. Ануфрієва, О. Суботенко, О. Янчук пропонують алгоритм оцінки ризиків осіб, які перебувають на обліку в органах пробації [2-5].

Визначальним чинником демократичного розвитку української держави були та залишаються права і свободи людини. Дотримання й охорона прав громадян, зокрема, засуджених, а також ефективна ресоціалізація колишніх злочинців є одним 3 основоположних критеріїв, що говорять про цивілізованість і рівень правової культури будь-якої держави, а також свідчать про активну європейську орієнтацію України. Отже, в умовах демократизації та гуманізації суспільства, державна політика країни має бути спрямована на забезпечення прав і свобод людини, а її законодавство приведено відповідно до міжнародних норм, стандартів i направлене на диференціацію виконання покарань та індивідуальний підхід як до засуджених, так і до осіб, які звільнились 3 місць позбавлення волі.

Функції ресоціалізації важко переоцінити. Вони покликані забезпечити: відновлення та подальший розвиток у засуджених корисних соціальних зв'язків; налагодження стосунків із суспільством; формування всебічно розвинутої особистості, яка здатна об’єктивно оцінювати себе та навколишній світ; виховання поваги до національних і загальнолюдських цінностей.

Частина 2 ст. 6 Кримінально-виконавчого кодексу України закріпила поняття ресоціалізації як «свідоме відновлення засудженого в соціальному статусі повноправного члена суспільства; повернення його до самостійного загальноприйнятого соціально-нормативного життя в суспільстві» [6].

Основними завданнями служби пробації є сприяння в наданні комплексної допомоги відповідно до потреб осіб, які перебувають у конфлікті із законом. Такі заходи спрямовані на те, щоб людина у майбутньому не вчиняла повторних кримінальних правопорушень. Зокрема, як показує європейська практика, інститут пробації акцентує свою увагу саме на безпеці суспільства. Суть пробації полягає також у встановленні нагляду за засудженим із покладенням на нього певних зобов'язань i обмежень, без ізоляції його від суспільства. Уся діяльність пробації та, зокрема, функція соціально-виховної роботи 3 правопорушниками спрямована на попередження нових кримінальних правопорушень. Але, варто зазначити, що у 
жодній країні світу ніхто не може гарантувати, що така діяльність забезпечить 100\% утримання суб'єктів органів пробації від вчинення нового злочину. Наразі у світі не існує жодного інструменту, який гарантував би повне виправлення всіх засуджених. Проте, існують різні способи впливу на кримінальну особистість, що мають високу ефективність, і які використовуються працівниками органів пробації.

Отже, працівники пробації $є$ постійними путівниками, помічниками та наставниками таких людей, які перебувають у конфлікті із законом. Працівник пробації набуває статусу учасника кримінального процесу 3 відповідними обов'язками та правами. Він також має право отримувати безкоштовно від будь-якого органу інформацію, необхідну для виконання завдань пробації, а також, з метою здійснення нагляду, має право відвідувати у будь-якому місці та на будь-якій території осіб, до яких застосовано пробацію, або викликати їх і отримувати від них пояснення. Невиконання законних вимог персоналу органу пробації тягне за собою відповідальність, встановлену законом. Серед працівників пробації $\epsilon$ не лише соціальні працівники, а й юристи та психологи, їх вводять до складу персоналу кожного підрозділу з метою підвищення ефективності виконання завдань пробації.

Робота з засудженим базується на вивченні його кримінальної історії, особистості та способу життя. Під час дослідження й аналізу виявляються проблемні аспекти, що у комплексі ймовірно зумовили вчинення ним кримінального правопорушення (як приклад може бути відсутність роботи, освіти, законних джерел доходів, складна ситуація в родині, вплив оточення, різного роду залежності, психологічні особливості тощо). Таким чином, одним із завдань працівників пробації можна вважати мотивування осіб, які вчинили кримінальне правопорушення, до змін на краще та на готовність вести правослухняний спосіб життя. В результаті цієї діяльності до суспільства повертається повноцінна людина, яка не порушує законодавство, працює, сплачує податки, створює сім'ю.

Працівники служби пробації проводять аналіз різних сторін життя засудженого, який показує, де саме в умовах життєдіяльності або особистісному розвитку були проблеми, які, скоріше за все, призвели до вчинення кримінального правопорушення, та на що треба вплинути, з метою мінімізації цих ризиків. Для працівників відповідних служб розроблені спеціальні інструменти оцінки ризиків вчинення повторного кримінального правопорушення, тобто тих ризиків, що визначають рівень небезпеки засудженого для суспільства.

Слід зауважити, що є чинники ризику (закономірності), які треба враховувати при застосування соціально-педагогічних і психологічних методів у роботі 3 засудженими. Перша закономірність - чим довший термін першого покарання у засудженого, тим йому важче, після його відбування, адаптуватися до політичних, економічних, соціальних змін у суспільстві, і коєфіцієнт вірогідності повторного повернення в місця позбавлення волі складає 0,87. Відповідно, особливу увагу треба приділяти засудженим, які вперше вчинили кримінальне правопорушення. Друга закономірність - рівень повторної та рецидивної злочинності серед засуджених пропорційно збільшується з кількістю судимостей у них не залежно від виду покарання. Як видно з наших досліджень, після першої судимості повторне кримінальне правопорушення вчиняє кожний сьомий колишній засуджений, після другої - кожний четвертий, після третьої - кожний 
третій, після четвертої - кожний другий, після п'ятої - 90\% від загальної кількості звільнених від покарання, встановленого судом. Третя закономірність: кожна наступна судимість засудженого пов'язана з попередньою однорідністю вчиненого ним кримінального правопорушення, але 3 більш важкими наслідками. Наприклад: перша судимість - крадіжка; друга - крадіжка, грабіж; третя - крадіжка, розбій; четверта - розбій, тяжкі тілесні пошкодження тощо. Четверта закономірність: засуджені проходять через такі етапи психологічного звикання до умов, які змінилися, незалежно від кількості судимостей, як: дезадаптація, адаптація, десоціалізація, ресоціалізація, соціалізація. Чим частіше засуджений притягується до кримінальної відповідальності, тим розмитій у часі етапи його психологічного звикання. Закономірність п’ята: однією із головних причин повторної і рецидивної злочинності є небажання работодавців брати на підприємства колишніх засуджених. Так, наприклад, рівень працевлаштування колишніх засуджених, за нашими даними, складає 23\%. Закономірність сьома: паралельно процесу ресоціалізації у процесі відбування покарання ми спостерігаємо процес підвищення «кримінальної кваліфікації» засуджених. Вивчення особових справ засуджених дає підставу зробити висновок, що кожний наступний склад злочину відрізняється від попереднього більш складною "професійною трансформацією" та способом реалізації злочинних задумів. Закономірність восьма: успіх процесу ресоціалізації залежить від участі в ньому не тільки працівників органів пробації, установ виконання покарань, але й різних суспільних, громадських, державних організацій, які надають соціальні послуги.

Таким чином, працівник служби пробації здійснює професійну діяльність, яка призначена забезпечити реалізацію державної політики у пенітенціарній сфері через виконання завдань і функцій, визначених Кримінально-виконавчим кодексом України та законом України «Про пробацію». Професійна діяльність працівників служби пробації має сприяти забезпеченню безпеки суспільства шляхом виправлення засуджених, запобігання вчиненню ними повторних кримінальних правопорушень, формуванню в державі системи справедливого правосуддя та скорочення кількості осіб, що вчиняють повторні кримінальні правопорушення.

\section{Список літератури:}

1. Електронний ресурс. Статистична інформація про стан злочинності в Україні. URL: https://old.gp.gov.ua/ua/statinfo.html (дата звернення 12.03.2021 року).

2. Максимова Н.Ю. Становлення соціальної роботи з засудженими в місцях позбавлення волі. Вісник Чернігівського національного педагогічного університету. Педагогічні науки. Чернігів, 2013. №108.1. С. 87 - 91.

3. Пахомов І.В. Особливості духовного виховання засуджених та персоналу ДКВС України. Труди Київської Духовної Академї Київ : Київська Духовна Академія, 2017. С. 333-341.

4. Супрун М. О. Сучасний стан проблеми підліткової девіації у соціальнопедагогічному контексті. Науковий часопис Національного педагогічного університету імені М.П. Драгоманова : Корекиійна педагогіка. Київ, 2015. Вип. 29. C. 244-249. 
5. Яковець I.C. Негативні наслідки для суб’єктів пробації в разі укладання угоди: проблеми практичного тлумачення. Вісник Пенітенціарної асоиіації України. Київ, 2008. № 2. С. 168-174.

6. Електронний peсурс. Кримінально-виконавчий кодекс України. URL: https://zakon.rada.gov.ua/laws/show/1129-15\#Text (дата звернення 12.03.2021 року). 


\title{
ДИСТАНЦЙНЕ НАВЧАННЯ В СИСТЕМІ СУЧАСНОЇ ШКІЛЬНОЇ ОСВІТИ
}

\author{
Яренчук Людмила Георгіївна \\ кандидат педагогічних наук \\ доцент кафедри технологічної \\ і професійної освіти та \\ загальнотехнічних дисциплін \\ Ізмаїльського державного \\ гуманітарного університету
}

Стратегічною метою державної політики є підвищення доступності якісної освіти, що відповідає вимогам інноваційного розвитку економіки. До числа пріоритетних напрямків модернізації системи освіти включена завдання широкомасштабного i комплексного впровадження інформаційних i комунікаційних технологій (IКТ). Цьому сприяють прийняті в Законі України «Про освіту» поправки, що закріплюють статус електронного навчання i дистанційних освітніх технологій (ДОТ). Відповідно до внесених змін в освітніх установах різного рівня з'являється можливість здійснення освітньої діяльності на основі дистанційних форм.

Незважаючи на те що довгий час було відсутнє нормативне регулювання, дистанційне навчання (ДН) впроваджувалося в умовах дослідноекспериментальної діяльності. Сьогодні склалися і реалізуються наступні напрямки застосування ДОТ в сучасних школах: дистанційне навчання дітей 3 обмеженими можливостями здоров'я; організація дистанційного контролю навчальних досягнень учнів; реалізація дистанційних освітніх технологій в додатковій освіті; організація профільного навчання із застосуванням ДОТ; проведення дистанційних уроків для пропускають шкільні заняття дітей 3 причин хвороби і в період карантину; дистанційна підтримка обдарованих дітей та науково-дослідницької діяльності учнів; організація шкільних систем віртуального спілкування; впровадження ДОТ в очне навчання (технології змішаного навчання) i ін.

Можливість реалізації дистанційного навчання в освітньому процесі забезпечується готовністю педагогів застосовувати ДОТ у своїй професійній діяльності, оцінювати потенціал і ефективність дистанційних форм роботи 3 учнями для вирішення дидактичних завдань. Це актуалізує спеціальну підготовку вчителів в області організації i методики ДО, оволодіння комунікаційними засобами і технологіями роботи в інформаційно-освітньому середовищі.

Дидактичної основою технологій ДО $є$ активна самостійна навчальна діяльність учнів, отже, професійна компетентність педагога в процесі дистанційного навчання проявляється в умінні планувати, організовувати, контролювати продуктивну самостійну роботу; мотивувати учнів до різним видам самостійної навчальної діяльності 3 використанням засобів ІКТ; 
моделювати предметне зміст в мультимедійної, інтерактивній формі; забезпечувати варіативність способів викладу, освоєння і закріплення досліджуваного навчального матеріалу з урахуванням індивідуального підходу [1, c.27].

Для успішного виконання даних функцій підготовка і перепідготовка вчителів повинні проводитися в двох взаємопов'язаних напрямках: дидактичні основи дистанційного навчання та інформационно-комунікаційні технології в дистанційному навчанні.

Дидактика дистанційного навчання передбачає знання організаційних особливостей освітнього процесу в умовах ДО, способів розвитку мотивації і пізнавального інтересу учнів в ДО; володіння освітніми технологіями в умовах ДО; вміння організувати самостійну навчальну роботу учнів 3 навчальним матеріалом дистанційного курсу; вміння забезпечувати підтримку оптимального зворотного зв'язку з учнями в ДО і ін.

Професійна підготовка в області ІКТ повинна забезпечити: формування умінь розробляти електронний навчально-методичний комплекс дистанційного курсу; володіння програмними інструментами для створення інтерактивних, мультимедійних електронних освітніх ресурсів (ЕОР) і умінь використовувати готові ЕОР; володіння засобами комп'ютерної комунікації.

Сучасні тенденції розвитку ДОТ пов'язані із застосуванням технологій Web 2.0, заснованих на спільній діяльності користувачів мережі: вики - технологія колективного створення web-pecypсів; блоги - ресурси для online публікацій i відкритого обговорення доповідей, рефератів, статей, авторських матеріалів; подкастинг - технологія, забезпечує можливість опублікування мультимедійної інформації та ін.

Сучасні дидактичні і технологічні рішення ДО орієнтовані на застосування систем дистанційного навчання (СДН), які забезпечують автоматизацію управління освітнім процесом і віддаленого спілкування між усіма його учасниками, єдину технологічну платформу для розміщення освітнього контенту i вирішення основних дидактичних завдань. Таким чином, обов'язковим компонентом професійної підготовки в області ДН є знання функціоналу та володіння інструментарієм СДН, що передбачають застосування технологій Web.2.0 для організації продуктивної взаємодії учнів [2, c.36].

Безперервна система підготовки вчителів до роботи в умовах ДН передбачає наступні компоненти: на етапі вузівської підготовки - вдосконалення професійної підготовки майбутніх вчителів за рахунок розробки та впровадження спеціальних дисциплін; застосування ДОТ у професійній підготовці майбутніх вчителів і в підвищенні кваліфікації практикуючих вчителів (опосередковане оволодіння ДНТ); курсова підготовка та перепідготовка педагогічних кадрів в області ДН на етапі підвищення кваліфікації; створення і підтримка інтегрованої інформаційної освітнього середовища «школа - педвуз», що містить необхідну дидактичну забезпечення ДН; створення творчих методичних об'єднань дистанційних педагогів; проведення регулярних конференцій, семінарів та круглих столів, присвячених проблемам ДН. 
У державному освітньому стандарті вищої освіти третього покоління за напрямом «Педагогічна освіта» приділяється увага важливій складовій професійної підготовки - професійної компетентності, яка передбачає готовність випускників застосовувати сучасні методики та технології навчання на основі IКТ, здатність організації навчально-виховного процесу на основі інформаційного освітнього середовища, здатність проектувати і розробляти методичне забезпечення освітнього процесу в умовах ДН [3, с.31].

Протягом останніх трьох десятиліть використання сучасних технічних засобів стало глобальним явищем освітньої та інформаційної культури, яка змінила підхід до утворення в багатьох країнах світу.

У нашій країні тільки в останнє десятиліття інформаційні освітні технології отримали інтенсивний розвиток, але вже впевнено стали завойовувати своє місце в освітньому процесі разом з традиційними формами навчання. Серед них все частіше ми починаємо говорити про дистанційне навчання, одному з найбільш вільних і простих методів навчання.

Дистанційне навчання як нова форма навчання i, відповідно як нова форма освіти активно формується і розвивається в нашій країні. Мета його дати учням елементи універсального освіти, що дозволяє їм адаптуватися до мінливих соціально-економічних умов і успішно інтегруватися в системі світової та національної культур. Це навчання будується на основі сучасних інформаційних технологій, які дозволяють швидко і гнучко координувати мінливі потреби учня.

Під дистанційним навчанням у середній школі слід розуміти освітню систему на основі комп'ютерних телекомунікацій 3 використанням сучасних педагогічних та інформаційних технологій. Дистанційне навчання - спосіб організації процесу навчання, заснований на використанні сучасних інформаційних і телекомунікаційних технологій, що дозволяють здійснювати навчання на відстані без безпосереднього контакту між викладачем і учням. Технологія дистанційного навчання полягає в тому, що навчання і контроль засвоєння матеріалу відбувається за допомогою комп'ютерної мережі Інтернет, використовуючи технології on-line i off-line.

Необхідність в такому методі навчання обумовлена різними факторами, серед яких можна назвати: потреба в інтерактивній взаємодії учнів і викладачів; робота 3 дітьми - інвалідами або часто хворіють; при заочній (екстернатної) формі навчання; виконання проектів і дослідних робіт; робота з обдарованими дітьми (індивідуальні додаткові завдання підвищеного рівня); захоплюючі завдання 3 метою повторення (кросворди, ребуси і ін.).

Технології дистанційного навчання дозволяють вирішувати ряд істотних педагогічних завдань: створення освітнього простору; формування в учнів пізнавальної самостійності і активності; розвитку критичного мислення, толерантності, готовності конструктивно обговорювати різні точки зору.

Дистанційне навчання не настільки впевнено і інтенсивно, але все ж входить і в середню освіту.

Виділяються наступні основні напрямки (моделі) впровадження електронного дистанційного навчання в систему загальної освіти: підвищення якості загальної освіти в малокомплектних школах; забезпечення доступності 
загальної освіти для дітей-інвалідів та дітей 3 обмеженими можливостями здоров'я, дітей, що мають поведінкові проблеми; забезпечення доступності загальної освіти для дітей, що мають тимчасові обмеження можливостей здоров'я і не мають можливості регулярно відвідувати освітні установи (які перебувають на госпіталізації в медичних установах, санаторії, будинки і т.п.); забезпечення доступності якісної загальної освіти на профільному рівні; забезпечення можливості продовження освітнього процесу в умовах запровадження карантину; забезпечення можливості додаткової освіти; забезпечення можливості навчання 3 окремих предметів 3 використанням дистанційних технологій; забезпечення можливості отримання загальної освіти 3 використанням дистанційних технологій (наприклад, учні, які тимчасово перебувають в іншому від основного місця проживання місті тривале відрядження батьків, участь в спортивних змаганнях і творчих і інтелектуальних конкурсах і т.п.); забезпечення можливості досить зручно готуватися до вступу до обраного вузу, використовуючи технології дистанційного навчання, де основним іспитом з математики прийнятий ЄДІ [4, с.77].

Для вчителів також відкриваються унікальні можливості підвищення кваліфікації не тільки за місцем проживання, а й у наукових центрах країни, можливість через віртуальні методичні об'єднання обмінюватися досвідом 3 колегами 3 інших регіонів, активно брати участь в форумах віртуального методичного об'єднання.

Розробка і реалізація інформаційних освітніх технологій і методів навчання, в тому числі дистанційних, позначено одним з основних заходів у державній програмі розвитку освіти, що забезпечують розвиток системи освіти в інтересах формування гармонійно розвиненої, соціально активної, творчої особистості і в якості одного 3 факторів економічного і соціального прогресу суспільства. Вважається, що поширення дистанційних освітніх технологій в результаті реалізації вищеназваної програми дозволить забезпечити входження в міжнародне інформаційне та комунікаційне простір.

Під дистанційними освітніми технологіями розуміються освітні технології, реалізовані в основному із застосуванням інформаційно-телекомунікаційних мереж при опосередкованому (на відстані) взаємодії учнів і педагогічних працівників.

Навчання з використанням дистанційних освітніх технологій (ДОТ) - одна 3 форм електронного навчання, при якому:

учень: вибирає форму навчання з використанням ДОТ, планує час вивчення матеріалу, планує послідовність вивчення матеріалу.

повинен: вивчити матеріал освітньої програми, досягти необхідних результатів навчання.

учитель: організовує освітній процес з використанням ДОТ, розробляє і надає навчальні матеріали, проводить формує i підсумкове оцінювання, консультує, надає допомогу,иє відповідальним за досягнення які навчаються планованих результатів. 
Навчання $з$ використанням ДОТ може застосовуватися системно, для вивчення цілого курсу однієї або декількох навчальних дисциплін або не постійно, а в зв'язку з виниклою необхідністю, наприклад:

При вивченні окремих тем курсу: для диференційованого або індивідуального навчання, для слабких учнів або дуже сильних учнів; навчання в окремі тимчасові проміжки (при тривалій хворобі, неможливість відвідувати школу в зв'язку з погодними явищами і т. п.).

При дистанційному навчанні важливим аспектом $\epsilon$ спілкування між учасниками навчального процесу, обов'язкові консультації викладача. При цьому спілкування між учнем і викладачем відбувається віддалено, за допомогою засобів телекомунікацій. У практиці застосування дистанційного навчання використовуються методики синхронного і асинхронного навчання $[5$, c.110].

Методика синхронного дистанційного навчання передбачає спілкування учня і викладача в режимі реального часу - on-line спілкування.

Методика асинхронного дистанційного навчання застосовується, коли неможливо спілкування між викладачем і учням в реальному часі - так зване offline спілкування.

3 розвитком дистанційного навчання, коли спілкування між учнем i викладачем відбувається не лицем до лиця в навчальній аудиторії, а переважно за комп'ютерним терміналом на різних кінцях мережевого кабелю, про синхронних i асинхронних методиках дистанційного навчання заговорили 3 точки зору застосування тих чи інших методик для підвищення ефективності навчання та здатності до навчання. При цьому різні методики навчання припускають різне навантаження на кожного з учасників навчального процесу дистанційного навчання.

Так, синхронна методика дистанційного навчання передбачає активну взаємодію викладача і учня i, таким чином, велике навантаження і на учня, i на викладача (тьютора). Викладач виступає свого роду "тягачем", що залучає i "тягне" за собою своїх учнів.

При асинхронній методиці дистанційного навчання більше відповідальності за проходження навчання покладається на учня. Тут на перший план висувається самонавчання, індивідуальний темп навчання, регулювання цього темпу навчання. Викладач (тьютор) при асинхронної методикою дистанційного навчання виступає консультантом, але в меншій мірі, ніж при синхронній методикою дистанційного навчання.

Останнім часом більшість фахівців прийшли до висновку, що найбільшої ефективності при дистанційному навчанні можна досягти при використанні змішаних методик дистанційного навчання. Термін "змішане дистанційне навчання" має на увазі, що програма навчання будується як 3 елементів синхронної, так і з елементів асинхронного методики навчання.

Виділяють основні форми дистанційного навчання: Відеолекції (of-line), online лекції (Skype технологіï); Відеоконференції (of-line, on-line), форуми, дискусії; 
Чат (відчути) - заняття (консультації, поточний оцінювання, ділові ігри, підсумкове оцінювання) - навчальні заняття, здійснювані з використанням чаттехнологій. Чат-заняття проводяться синхронно, тобто всі учасники мають одночасний доступ до чату. В рамках багатьох дистанційних навчальних закладів діє чат-школа, в якій за допомогою чат-кабінетів організується діяльність дистанційних педагогів і учнів.

Вебінари (on-line семінари, тренінги, практичні заняття) - дистанційні уроки, конференції, семінари, ділові ігри, лабораторні роботи, практикуми та інші форми навчальних занять, що проводяться за допомогою засобів телекомунікацій та інших можливостей мережі Інтернет. Для веб-занять використовуються спеціалізовані освітні веб-форуми - форма роботи користувачів з певної теми або проблеми з допомогою записів, що залишаються на одному з сайтів 3 встановленої на ньому відповідною програмою. Від чатзанять веб-форуми відрізняються можливістю більш тривалої (багатоденної) роботи і асинхронним характером взаємодії учнів і педагогів [19, с.115].

Для реалізації навчання з використанням елементів в ДОТ, необхідні наступні засоби управління: Сайт школи: електронний журнал, щоденник; Net школа.

Навчальний контент: сайт вчителя, ЦІОР, ЄК ЦОР, КМ школа, ресурси Інтернету.

Сервіси Інтернету: E-mail, сервіси колективної роботи:

- зберігання, спільне редагування документів;

- блог, сайт вчителя - методичні ресурси вчителя;

- ресурси створення карт знань, роботи з геокартами, мережеві інтерактивні дошки.

При системному навчанні 3 використанням ДО до організації процесу навчання пред'являються певні вимоги:

- спеціально розроблений мультимедійний інтерактивний навчальний контент курсу, система курсів навчання,

- аппаратурно-програмне забезпечення управління навчальним процесом,

- організаційна структура (диспетчер, мережеві методисти, вчителі, тьютори),

- служба технічної підтримки (мережевий адміністратор, програмісти, інженери та лаборанти для обслуговування техніки, програмного середовища, навчального процесу),

- комплекс нормативних документів [6, с.204].

Таким чином, організувати спілкування з учнями по електронній пошті, створити блог і розмістити там завдання для дітей, створити таблицю для фіксування результатів виконання завдань і надати доступ до неї всім учням, організувати в блозі обговорення будь-якої теми - це повинні вміти всі вчителі.

Крім того, кожен вчитель, який працює з використанням елементів в ДОТ, повинен вміти створювати і використовувати дистанційні навчальні курси.

Дуже корисна могла б бути дистанційна форма навчання для системи профільного навчання. 3 іiі допомогою можна було б організувати профільне навчання не тільки по чотирьох певним МО напрямками, але і по багатьом i багатьом іншим, які б дозволили учням краще познайомитися 3 тією областю знання, яку вони вибрали для себе. 
Дистанційна форма навчання могла б виступити серйозним конкурентом для всякого роду репетиторства при вступі до вищих навчальних закладів.

Нарешті, дистанційна форма навчання могла б дати можливість учням ліквідувати прогалини в знаннях або навпаки поглибити свої знання в цікавих для них областях.

Безсумнівно, дистанційна освіта має свої переваги. Вона допомагає:

- вчитися людям з фізичними вадами, які мають індивідуальні риси i неординарні особливості;

- вирішувати психологічні проблеми учнів;

- знімати часові та просторові обмеження і проблеми;

- правильно оцінити і розрахувати свої сили, організувати свою діяльність;

- розширювати комунікативну сферу учнів і педагогів;

- проявляти свої здібності до творення, реалізувати потребу фантазувати, вигадувати, творити.

\section{Список літератури:}

1. Агапонов С.В. и др. Средства дистанционного обучения. Методика, технология, инструментарий. СПб.: БХВ-Петербург, 2003. - 336 с.

2. Бакушин А.А. Инновационные процессы в технологиях обучения. М.: Гардарики, 2005. -288 с.

3. Андреев А.А. Введение в дистанционное обучение // Компьютеры в учебном процессе. М.: Интерсоциоформ, 1998. № 2. С.25-68.

4. Ананьев Б.Г. Психология педагогической оценки // Избр. психол. труды: в 2 т. М.,1980. T.2. -330 c.

5. Беляев К.В. Средства индивидуализации дистанционного профессионального обучения // Журнал «Дополнительное профессиональное образование». № 5. 2005. - С.110-122.

6. Беспалько В.П. Образование и обучение с участием компьютеров (педагогика третьего тысячелетия). М. МПСИ, 2002. - 352 с. 


\section{ОСНОВНІ ПРИНЦИПИ РЕКЛАМНОГО ТЕКСТУ}

\section{Григоров Степан Станиславович}

студент

Национальный технический университет Украины «Киевский политехнический институт имени Игоря Сикорского» (КПИ)

На сьогоднішній день реклама всюди: на вулицях, по телевізору, в Інтернеті тощо. Ї̈ї настільки багато, що лінгвісти почали вивчати рекламні тексти, аби дослідити їхній ефект, а також перспективи розвитку. Серед науковців, які приділили увагу і продовжують дослідження рекламного дискурсу можна виокремити С. Ю. Тюрину, Т. В. Колісниченко, С.В. Столярську та інших.

Актуальність нашої роботи зумовлена популяризацією маркетингового дискурсу у різних сферах життя людини. У цій площині, рекламні тексти виступають інструментом реалізації подібного дискурсу, методом його відтворення у реальному житті за тих чи інших обставин.

Мета нашої роботи полягає у визначенні основних принципів рекламного тексту 3 метою поглиблення знань про вплив та особливості, пов'язані з ним.

Перед тим, як перейти до головного питання нашої роботи, варто визначити, що ж таке рекламний текст. На думку С. Ю. Тюриної, це $\epsilon$ текст, поглиблений у ситуацію рекламного спілкування. Рекламний текст може мати такі особливості, як аудіовізуальний характер, або будь-яку іншу форму відтворення [1].

Додаючи до слів С. Ю. Тюриною, варто підкреслити вислів “будь-яку" форму, адже у сучасному світі, цифровому світі, нові середовища реалізації рекламного або маркетингового дискурсу з'являються у різних сферах життя людини.

3 приводу основних принципів рекламного тексту, варто замислитися, чому ж такі тексти приділяють увагу читачів, глядачів, слухачів тощо. Що ж саме змушує людей звертати свою увагу на той чи інший банер на вулиці, або ж рекламу на екрані телевізора?

По-перше, будь-яка реклама завжди є лаконічною. Якщо це банер, то має бути вмістким. Існує так зване правило "мінімакса", а саме мінімум слів максимум інформації.

По-друге, конкретність, адже реклама повинна бути спрямована на конкретний продукт. Наприклад, продуктом може бути, як марка машини, так i його модель.

По-трете, зрозумілість тексту. Він повинен бути спрямований на певну аудиторію. Наприклад, якщо це молодь, то варто застосувати молодіжний сленг, якщо це працівники банківського сектору, то відповідне професійне арго. 
Четвертою вимогою $є$ виразність, адже текст повинен бути таким, щоб його запам'ятали. Лінгвістичні вирази, каламбури, гра слів ідеально пасують для виконання цієї умови.

П'ятим пунктом $\epsilon$ оригінальність, адже саме вона допомагає тексту виокремитись серед інших. До цього пункту також належить особливість форми, а також інформативність.

Переходячи до прикладів, у нашій роботі було використано 3 рекламних тексти французькою мовою за довільними вимогами, аби уникнути упередження:

- “d'ego - d'eco" - “від его - від еко” (дослівний) - використання паронімів у французькому оригіналі. Схожість двох слів, а також їхня семантична різниця є доволі оригінальними. Рекламний текст з лінгвістичної точки зору складається з 2 висловів, тобто є лаконічним. Рекламний текст містить такий вираз на позначення мотивів вчинків людини [2, с. 10].

- "Nous travaillons chaque minute à ce que vous ne perdiez une seule" - "Mu працюємо кожну хвилину, аби ви не втратили ні однӧ” - Влучний вислів у рекламі інтригує потенційного клієнта обіцянкою. Лаконічність вислову, оригінальність побудови фрази, простота сенсу, направленість на один продукт - принесли успіх рекламному тексту [3].

- “Du jamais bu!” - “Такий ви ще не куштували!” - Представлений у рекламі вираз є переробкою сталого французького виразу "Du jamais vu”, який перекладається як “Той, який ще не бачили”. Маркетинговий хід, зроблений у рекламі напою, є доволі оригінальним, лакончним та зрозумілим [4].

Отже, рекламний дискурс стає більш розпоширеним не тільки у побуті, але й у науковому полі: вчені вивчають різни аспекти рекламних текстів, досліджують їхні особливості. У роботі було наведено 5 основних принципів рекламних текстів, які, на нашу думку, є основними при сприйнятті реклами у лінгвічстичній площині. Серед них лаконічність, зрозумілість, оригінальність, виразність і конкретність. Також було наведено приклади, які відповідають наведеним пунктам і мають (або мали) маркетинговий успіх.

\section{Список литературы:}

1. Тюрина С. Ю., О понятиях рекламный дискурс и рекламный текст. Іваново: “Вестник ИГЭУ”, 2009. 3 с.

\section{Джерела ілюстративного матеріалу:}

2. Bilan 2009 Publicité et Langue Française [Електронний ресурс] : (файл) / ARPP (Autorité de régulation professionnelle de la publicité). - Електрон. Дані (1 зображення). - 2009. - Режим доступу: https://www.arpp.org/IMG/pdf/bilan_2009_new_logo-3.pdf (дата звернення: 14.03.2021).

3. Uber célèbre ses 5 années en France [Електронний ресурс] : (веб-сторінка) / LLLLITL. - Електрон. Дані (1 зображення). - 2017. - Режим доступу: https://www.1lllitl.fr/wp-content/uploads/2017/09/uber-avancer-avec-vous-5-ans-francepublicite-communication-affichage-ddb-paris-3.jpg (дата звернення: 14.03.2021).

4. Pinterest [Електронний pecypc] : (веб-сторінка) / Pinterest. - Електрон. Дані (1 зображення). $\quad$ - $2012 . \quad$ - $\quad$ Режим доступу: https://www.pinterest.fr/pin/313844667763347741/ (дата звернення: 14.03.2021). 


\title{
К ВОПРОСУ О ХРОНОТОПАХ В ПОВЕСТИ Н. В. ГОГОЛЯ «МАЙСКАЯ НОЧЬ, ИЛИ УТОПЛЕННИЦА»
}

\author{
Павельева Анна Константиновна, \\ к. филол. н., доцент, доцент кафедры \\ германской филологии и перевода \\ Национального университета \\ «Полтавская политехника \\ имени Юрия Кондратюка»
}

Особенности художественного времени в повести «Майская ночь, или утопленница» подчеркиваются уже самим ее названием, ведь, выбрав его, автор подчеркнул, что временная протяженность событий, описанных в повести, имеет особое значение, так как суточное время - ночь - пора господства тайных сил. У Гоголя это время фантастическое, время чудес, ведь именно ночью утопленницы водили хороводы, покойник с галушкой в зубах «таскался» к покойной теще винокура т.д.

Хронотоп ночи у Гоголя один из самых сложных. В нем сливаются воедино космическое, суточное, календарное, мистериальное, идиллическое время с пространством открытым, земным и космическим, реально видимым и воображаемым, близким и удалённым. Образ времени и пространства украинской ночи в гоголевской повести «оживает», приобретая черты полноценного «персонажа»: «необъятный небесный свод раздался, раздвинулся еще необъятнее. Горит и дышит он. Земля вся в серебряном свете; и чудный воздух и прохладно-душен, и полон неги, и движет океан благоуханий. Божественная ночь! Очаровательная ночь! Недвижно, вдохновенно стали леса, полные мрака, и кинули огромную тень от себя. Тихи и покойны эти пруды; холод и мрак вод их угрюмо заключен в темно-зеленые стены садов. Девственные чащи черемух и черешен пугливо протянули свои корни в ключевой холод и изредка лепечут листьями, будто сердясь и негодуя, когда прекрасный ветреник - ночной ветер, подкравшись мгновенно, целует их. Весь ландшафт спит. А вверху все дышит, все дивно, все торжественно. А на душе и необъятно, и чудно, и толпы серебряных видений стройно возникают в ее глубине. Божественная ночь! Очаровательная ночь! И вдруг все ожило: и леса, и пруды, и степи. Сыплется величественный гром украинского соловья, и чудится, что и месяц заслушался его посереди неба... [1, с. $50-51]$. Ночь, которую видит Левко во сне, кажется еще более очаровательной: «ночь казалась перед ним еще блистательнее. Какое-то странное, упоительное сияние примешалось к блеску месяца. Никогда еще не случалось ему видеть подобного. Серебряный туман пал на окрестность.... [1, с. 62].

Повесть «Майская ночь, или утопленница» открывается хроникальнобытовым хронотопом - описанием так называемой «улицы». Это молодежные гуляния вроде «вечерниц», только под открытым небом. Продолжались они приблизительно с 7 и до 10-11 вечера, весело и с музыкой. Пора «улицы» 
начиналась с ранней весны и до поздней осени, когда с приходом холодов гуляния («вечерницы») переносились в хату. «Звонкая песня лилась рекою по улицам села ***. Было то время, когда утомленные дневными трудами и заботами парубки и девушки шумно собирались в кружок, в блеске чистого вечера, выливать свое веселье в звуки, всегда неразлучные с уныньем» [1, с. 45], - пишет Гоголь. Изображаемое мыслится автором как существующее всегда, поэтому хроникально-бытовой хронотоп обладает большой степенью абстрактности. Хотя место действия точно не названо или вымышлено (село ***), в повести создан образ универсального или всеобщего пространства, который, несомненно имеет реальный аналог: это обобщенный образ «малороссийского» села со всеми его постройками, жителями, обычаями и нравами. Тем не менее, принимая во внимание народные традиции, мы можем с уверенностью сказать, что это время, около 8-9 часов вечера, когда «парубки» и «дивчата» собирались после рабочего дня на отдых - «в блеске чистого вечера» это. То есть зная календарное время (май) и время захода солнца в этом месяце, можно вычислить, когда начинается фабульно-сюжетное время.

Хроникально-бытовое время (изображение уклада жизни украинского села) воспроизводит в данной повести не динамику, а статику. Это и свидания в саду, и «улица», и проделки парубков, и манера поведения головы с односельчанами и односельчан с ним, и его вечные пересказы проводов царицы: «и с той поры голова, об чем бы ни заговорили с ним, всегда умеет поворотить речь на то, как он вез царицу и сидел на козлах царской кареты [1, с. 52]).

Суточное время у Гоголя имеет ярко выраженную характерность - переходы из временного плана в пространственный: «... задумавшийся вечер мечтательно обнимал синее небо, превращая все в неопределенность и даль» [1, с. 45]. Ганна выходит из хаты «обвитая сумерками», а «сизый туман» «одевает» винокура. Эти примеры говорят о том, что пространство у Гоголя также обладает повышенной насыщенностью.

Следует заметить, что пространство Украины у Гоголя замкнутое: «...необъятно синело теплое украинское небо, завешенное снизу кудрявыми ветвями...» [1, с. 48]. То есть украинское небо мыслится как купол, накрывающий благодатную землю. Так, еще в повести «Сорочинская ярмарка» Гоголь описывает небо, как «голубой неизмеримый океан, сладострастным куполом нагнувшийся над землею» [1, с. 11]. В обоих случаях наблюдается также авторская интенция расширить границы этого замкнутого пространства (небо - необъятное и неизмеримое). Но это пространство не бесконечно и досягаемо: «задумавшийся вечер» и лес «обнимали» небо. В повести «Сорочинская ярмарка» Гоголь называет небо океаном, а в повести «Майская ночь, или утопленница» пруд сливается в поцелуе с ночным небом, преобразовываясь в единое фантастическое пространство.

Пространство повести в мифологическом смысле трехуровневое. Это земной мир людей, мир божественный - небесный и мир подводный - инфернальный. Изображение «человеческого пространства», в противовес «водяному» (нечистому пространству утопленниц) даётся в зеркальном отражении. Левко и Галя смотрят на небо, а оттуда «ангелы божии поотворяли окошечки своих 
светлых домиков на небе» и глядят на них. К тому же, Левко косвенно подтверждает близость этих пространственных пластов историей о том, как перед светлым воскресеньем архангелы ставят для Бога лестницу, которая тянется от неба до земли. При этом «все нечистые духи полетят стремглав и кучами попадают в пекло», то есть в подземное пространство. В данной повести роль «низшего уровня» исполняет пруд.

Повесть «Майская ночь, или утопленница» характеризуется изображением «nараллельных пространств». В то время, как Левко с Ганной любуются звездным небом, Каленик заблудился и был направлен в хату головы. В то время, как парубки переодевались и разучивали срамную песню про голову, тот заканчивал свой ужин с винокуром. Пока Левко с товарищами проказничали, убегали от головы и десятских и пока парубок во сне помогал утопленнице, Ганна безмятежно спала, облокотившись на подоконник. Смысл времени суток в повести индивидуализирован и варьирован: девушка сладко спит, в то время как представителей власти и парубков ночь пролетает в маскараде и погонях, пьяный Каленик все шатался по селу.

Подверженность пространства нечистой силе в этой повести увеличивается. Выясняется, что ведьма может «портить» не только бытовое, «человеческое» пространство, но и мифологическое (подводное) пространство неупокоенных душ. «Сотникивна» не может из-за неё свободно плавать, а тонет и падает на дно. Если в повестях «Сорочинская ярмарка» и «Вечер накануне Ивана Купала» нечистая сила деформировала только земное и воздушное пространство, то в данной повести ведьма негативно влияла и на подводный мир утопленниц.

Изображение субъективного времени персонажей - Ганны и Левка позволяет автору индивидуализировать героев, показать их темперамент и характер. Так, Левко говорит Гале: «мне и часу не видать тебя горько». Девушка укоряет его в нетерпеливости и вспыльчивости: «уже и рассердился». В то же время она тоскует, «два месяца только в стороне родной, и уже соскучилась» $[1$, c. 47]. Галя не спешила выходить к возлюбленному, который томился неизвестностью. Они по-разному воспринимают время. Здесь наблюдается связь между интенсивностью бега времени в глазах героев и их душевным состоянием - страстной влюбленностью Левка, и спокойной влюбленностью Гали.

Фабульно-сюжетное время имеет двойственный характер. Это тёплая майская ночь и ночь, когда «давно» в заброшенном, обросшем мхом доме жил сотник с дочерью. В рассказе Левка наблюдается динамизация времени, подчеркивающая трагичность судьбы «сотникивны», злобность её мачехиведьмы и силу её чар. Так, автор только упоминает о том, что в первую ночь после свадьбы (в мистическое, бесовское время) молодая жена сотника превратилась в кошку и попыталась задушить свою падчерицу. Два дня она не выходила из светлицы. На третий день появилась с перевязанной рукой, на четвертый - отец запретил дочке появляться в панских покоях, а на пятый день он уже выгнал её из дому, и «сотникивна» утонула. То есть, с начала деформации ведьмой идеального семейного пространства дома сотника до момента его полного разрушения прошло всего пять дней. 
«С той поры» панночка «всякую ночь» собирает утопленниц и угадывает среди них ведьму. Таким образом, эти два пласта сюжетного времени (настоящее для Левка и Ганны и давнее прошлое, когда произошла эта история) сливаются в фантастическом времени майской ночи.

В отличие от повести «Сорочинская ярмарка», где мотив порога означает переход Параски в новую, счастливую жизнь, в повести «Майская ночь, или утопленница» порог является барьером между надежным пространством дома, и небезопасным - улицы. Так, переступая порог, Галя вынуждена терпеть поцелуи парубков и признания головы; а свояченица дважды оказывается схваченной и запертой.

Хронотоп дороги в данной повести выполняет дескриптивную функцию. Он намеренно «растянут» для описания событий, происходящих в то же время в другом месте и для характеристики героев. После того, как Левко уходит домой, к его Ганне приходят другие ухажеры. В то время как Каленик добирается к хате головы, повествователь успевает описать это «важное лицо на селе». Рассказчик сознательно «растягивает время», знакомя читателя с сельским головою: «покамест Каленик достигнет конца пути своего, мы, без сомнения, успеем коечто сказать о нем» $[1$, с. 52]. Нужно заметить, что пьяный мужик был недалеко от дома головы, на который ему указали «дивчата», и идти к нему было, несомненно, недолго. Но повествователь успел охарактеризовать за это время полжизни сельского головы: «Но мы почти все уже рассказали, что нужно, о голове; а пьяный Каленик не добрался еще и до половины дороги...» [1, с. 52]. Пьяному мужику этот недолгий путь показался чрезвычайно длинным: «Вишь, как растянул вражий сын, сатана, дорогу! Идешь, идешь, и кониа нет!» [1, с. 56].

Мотив сна играет в данной повести особую роль. Во сне пространство изменилось до неузнаваемости, заброшенный господский дом предстал перед Левком новехонькой постройкой, «в каком-то ясном величии». События, происходящие во сне, сопровождаются дымкой, пространственной вуалью. Вся окрестность была окутана «тонким серебряным туманом», а что касается утопленниц, то «тело их было как будто сваяно из прозрачных облак и будто светилось насквозь при серебряном месяце...» [1, с. 64].

Сон в повести «Майская ночь, или утопленница» является не просто иным, ирреальным пространством, реализующимся только ночью. Сон у Гоголя «пропитан» подсознательным. Во сне сбывается самое сокровенное желание Левка: он получает записку от комиссара, которая способствует его скорой женитьбе. В то же время, со сном в этой повести связаны мотивы отмщения, воцарения справедливости. Так, мачеха-ведьма, долго мучившая «сотникивну», наконец была наказана, и душа утопленницы обрела покой.

Следует отметить, что сон Левка заканчивается в полночь. Полночь - апогей в деятельности нечистой силы, время, которому приписывалась особая мистическая значимость. Примечательно, что как раз в это время бесы начинали шалить, а приключения парубка закончились до наступления этих таинственных минут. Это подчеркивает «безгрешность» Левка, его бескорыстность. В отличие от Петруся (героя повести «Вечер накануне Ивана Купала), который в полночь пустился искать сокровища, Левко расстался с утопленницами до полуночи и не 
просил у них выгоды для себя. Таким образом, читатель может быть уверен в чистом и безмятежном счастье Левка и Ганны (в противовес добытому нечистыми способами благополучию Грицька и Параски или Петруся и Пидорки). Настоящее время как бы предвещает героям счастливое будущее.

Примечательно, что мотив сна у Гоголя также очень сложен. Герою не просто привиделись чудеса, но пространственные преобразования он увидел в пруду. Красавица-утопленница также является парубку сначала в зеркальном отражении, когда Левко любуется её отображением в воде. Таким образом, автор плавно вводит в повествование ирреальное мифологическое пространство владения низших мифологических существ (вроде водяных и русалок) и духов.

Новаторство Гоголя в пространственно-временной сфере имеет разнообразные формы выражения. Художественное время повести завершенное. Повесть заканчивается не просто победой героя или обещанной свадьбой, но блаженным сном: «...чрез несколько минут всё уже уснуло на селе», кроме пьяного Каленика, пытающегося найти свою хату. Ирреальное, мифологическое время переходит в суточное в традиционном его значении - ночь как время отдыха и успокоения.

Среди хронотопических мотивов и образов в повести следует выделить также хронотоп дороги, хронотоп садка, являющегося местом свиданий, хронотоп окна (у окна Левко умоляет Ганну выйти к нему и в окне появляется красавицаутопленница). Хронотоп двери является символом ограждения от опасности. Например, Ганна захлопывает дверь перед парубками, а голова - перед свояченицей, принятой за сатану. Примером хронотопа является дверная ручка, которую боится выпустить из рук робкая Ганна и которую быстро и ловко поворачивает хитрый голова, изловчившись таким образом поймать проказника в вывороченном тулупе. Перечень хронотопов повести будет неполным без хронотоп пруда (угрюмого и унылого пристанища утопленниц) и заброшенного дома (места злодеяний ведьмы и тоски «сотникивны»).

\section{Литература:}

1. Гоголь Н. В. Вечера на хуторе близ Диканьки. Миргород. - Харьков: Прапор, 1987. - 347 с.

2. Бовсунівська Т. В. Містична каузальність гоголівських сюжетів / Тетяна Володимирівна Бовсунівська // Українська мова та література. - 1999. - № 12. С. $6-7$.

3. Бондаренко Ю. Хронотопічний аналіз тексту у світлі філософськоісторичних підходів до вивчення літератури / Ю. Бондаренко // Українська мова і література в школі. - 2007. - № 4. - С. $21-24$.

4. Заманова И. Ф. Пространство и время в художественном мире сборника Н. В. Гоголя «Вечера на хуторе близ Диканьки»: дис. ... канд. филол. наук : 10.01.01 / Ирада Фуадовна Заманова. - Орёл, 2000. - 186 с.

5. Мацапура В. И. Н. В. Гоголь : художественный мир сквозь призму поэтики / В. И. Мацапура. - Полтава : Полтав. літератор, 2009. - 304 с.

6. Павельева А.К. Художественное время и художественное пространство в повести Н.В. Гоголя «Майская ночь, или утопленница». Стратегї̈ розвитку та 
пріоритетні завдання філологічних наук: Матеріали всеукраїнської науковопрактичної конференції, $19-20$ жовтня 2018 р. Запоріжжя : Класичний приватний університет, 2018. С. 28 - 32.

7. Павельева А.К. Об актуальности исследования категорий художественного времени и художественного пространства в первых циклах Н.В. Гоголя. Наука і техніка сьогодення: пріоритетні напрямки розвитку України та Польщі: матеріали Міжнародної мультидисциплінарної конференції, 19 - 20 жовтня 2018 р. Польща, м. Воломін : Z. Gloger Wolomin International and Regional Cooperation University, 2018. T. 1. C. $169-172$. 


\title{
НАЗВИ РЕМІСНИКІВ ТЕКСТИЛЬНОГО РЕМЕСЛА У СХІДНИХ НІМЕЦЬКИХ ДІАЛЕКТАХ ХІV-XVII СТОЛІТЬ
}

\author{
Пиц Тарас \\ кандидат філологічних наук, доцент \\ Львівський національний університет \\ імені Івана Франка
}

Реміснича термінологія - важлива та невід'ємна частина словника кожної мови. 3 поширенням Магдебурзького права ремісники організовувалися в цехи, отримували захист від утисків можновладців і конкуренції сільських ремісників, які переселялися до міст, а також мали право самостійно регламентувати виробничу діяльність (обирати продукцію, визначати якість, встановлювати ціни), запроваджували і використовували нові технічні прийоми, ремісничі інструменти, пристрої. Внаслідок цього відбувається членування галузей ремесел на споріднені. Усі ці нововведення відображаються також у мові: виникають нові назви на позначення виробів, інструментів, процесів виробництва, а також - ремісників.

Друга світова війна почасти зруйнувала мовну картину Центральної Свропи. Зникає частина німецькомовного ареалу: нижньопрусський, верхньопрусський i східнопомеранський діалекти. Майже повністю зникає сілезький говір. Із їхнім зникненням в середині ХХ ст. втрачається не лише «живий» матеріал для їхнього дослідження, але й зникає саме та частина німецькомовного ареалу, що була реальним «мостом» для поширення запозичень у слов'янські мови не лише зі східних, але й інших німецьких діалектів та західноєвропейських мов. Єдиним шляхом вивчення різних груп лексики та мовних явищ зниклих говорів залишаються пам'ятки цих діалектів, словники апелятивної, ономастичної лексики та лінгвістичні атласи. Відповідно вивчення і реконструювання частково чи повністю зниклих німецьких говорів становить чималий інтерес для сучасного мовознавства, що й обгрунтовує актуальність цього дослідження.

Сілезькі назви текстильників, які лягли в основу відпрофесійних прізвиськ, розглядалися дослідниками серед інших назв ремісників в ономастичних студіях Г. Райхерта [12] і Г. Балова [1-4]. Назви ремісників в історичних назвах вулиць м. Бреслау виявив Г. Маркграфом [11]. Окремі нотування саме назв ремісників, що займалися текстильними ремеслами, знаходимо у працях Г. Корна [9] і В. Юнгандреаса [8]. Про назви нижньопрусських ремісників дізнаємося 3 монографії Т. Гірша [7], а також зі словників нижньопрусського діалекту Г. Фрішбіра [6] та В. Ціземера [14]. Матеріалом для збору східнопомеранських назв ремісників слугували дослідження О. Блюмке [5] та Г. Лемке [10]. Також назви вулиць, пов'язані 3 давніми професіями та ремеслами всієї Німеччини, досліджував Е. Фолькманн [13]. Водночас відсутнє окреме спеціальне дослідження давніх назв ремісників текстильних ремесел (а також інших галузей ремісництва) колишніх східних німецьких діалектів чи одного з них зокрема. 
У проаналізованій науковій літературі виявлено 32 назви ремісників, які займалися текстильними ремеслами. Виробленням вовняного сукна та полотна займався 21 ремісник, виготовленням ниток, шнурів, канатів - 11. Від назв ремісничих виробів утворено 17 назв текстильників (Bändler, Breittuchmacher, Gewandscherer, Kabeldreher, Leinenweber, Posamentierer, Reeper, Reepschläger, Schleierer, Schmuckler, Schnurer, Schnurmacher, Seiler, Stricker, Tuchscherer, Wollenweber, Züchner, Zwirner); матеріалу, з якого виготовлені вироби - 5 (Garnzieher, (Tuch)knappe, Tuchmacher, Wollenschläger, Wollner); назви виконуваної дії - 6 (Bleicher, Färber, Kämmer, Walker, Wäscher, Weber); загальної характеристики виробів - 2 (Breittuchmacher, Schöneweber) назви кольору - 1 (Schwärzer); заводу (красильні) - 1 (Rodeler). 13 ремісничих найменувань утворено за допомогою суфікса -er, інші - його варіантів -ler (Bändler, Schmuckler, Rodeler), -ner (Wollner, Züchner), -ierer (Posamentierer). Другими твірними основами у різнокореневих назвах ремісників слугують -schläger (Reepschläger, Wollenschläger), -weber (Leinenweber, Schöneweber, Wollenweber), -scherer (Gewandscherer, Tuchscherer), -macher (Breittuchmacher, Schnurmacher, Tuchmacher), -zieher (Garnzieher), -knappe (Tuchknappe), -dreher (Kabeldreher).

Засвідчені форми фіксації назв ремісників фіксують також історичні зміни у системі консонантизму і вокалізму: а) послаблення голосних у афіксах (webirweber, Bleichir-bleicher); б) підняття о > u (wollenwebir-wullenweber); в) синкопу (czichener-Züchner); г) дисиміляцію із зникненням приголосного (lyn(n)enweberlynnewebir, wullenwebir-wulwewer); д) контрактацію (wollinsleger-wollensleer, cabildreger-Kabeldreher); е) зміну $\mathrm{w}>\mathrm{b}$ (wulwewer-wullenwebir); є) зміну свн. $\mathrm{s}$ перед $1>$ sch (reepsleger-Reepschläger).

Крім цього виокремлено 6 синонімічних рядів: Wollner-WollenschlägerKämmer „той, що чистить і розпушує вовну“; Bleicher-Wäscher „той, що вибілює полотно“; Scherer-Gewandscherer-Tuchmacher „той, що завершує приготування полотна“; Schnurer-Schnurmacher „той, що виготовляє шнури“; Seiler-Stricker „виробник легких тросів, канатів тощо“; Reeper-Reepschläger „виробник важких обсмолених тросів, линв, канатів“.

\section{Список літератури}

1. Bahlow H. Liegnitzer Namenbuch: Familiennamen, gedeutet aus den Quellen des Mittelalters / Hans Bahlow. - Lorch : Weber, 1975. - 160 S.

2. Bahlow H. Mittelhochdeutsches Namenbuch nach schlesischen Quellen: Ein Denkmal des Deutschtums / Hans Bahlow. - Neustadt an der Aisch : Degener \& Co, 1975. - $182 \mathrm{~S}$.

3. Bahlow H. Schlesisches Namenbuch / Hans Bahlow. - Kitzingen : Holzner, 1953. - $147 \mathrm{~S}$.

4. Bahlow H. Studien zur ältesten Geschichte der Liegnitzer Familiennamen / Hans Bahlow // Mitteilungen des Geschichts- und Altertumsvereins für die Stadt und das Fürstentum Liegnitz. - Liegnitz : Krumbhaar, 1926. - Bd. 10. - S. 102-162.

5. Blümcke O. Die Handwerkszünfte im mittelalterlichen Stettin / Otto Blümcke // Baltische Studien. - Stettin : Herrcke \& Lebeling, 1884. - S. 81-247. 
6. Frischbier H. Preussisches Wörterbuch: ost- und westpreußische Provinzialismen in alphabetischer Folge / Hermann Frischbier. - Berlin : Enslin, 18821883. - Bd. I-II.

7. Hirsch Th. Danzigs Handels- und Gewerbsgeschichte unter der Herrschaft des Deutschen Ordens / Theodor Hirsch. - Wiesbaden : Sändig [Nachdr. von 1858], 1969. $-344 \mathrm{~S}$.

8. Jungandreas W. Zur Geschichte der schlesischen Mundart im Mittelalter / Wolfgang Jungandreas. - Breslau : Maruschke \& Berendt, 1937. - 586 S. + LXIV S.

9. Korn G. Schlesische Urkunden zur Geschichte des Gewerberechts insbesondere des Innungswesens aus der Zeit vor 1400 / Georg Korn. - Breslau : Josef Max \& Comp, 1867. - 137 S.

10. Lemcke H. Die älteren Stettiner Straßennamen im Rahmen der älteren Stadtentwicklung / Hugo Lemcke [2. neu erarb. Aufl. von G. Fredrich]. - Stettin : Saunier, 1926. -92 S.

11. Markgraf H. Die Straßen Breslaus nach ihrer Geschichte und ihren Namen / Hermann Markgraf. - Breslau : Morgenstern, 1896. - 244 S.

12. Reichert H. Die deutschen Familiennamen nach Breslauer Quellen des 13. und 14. Jahrhunderts. - Breslau : M. \& H. Marcus, 1908. - 192 S. + IX S.

13. Volckmann E. Alte Gewerbegassen: deutsche Berufs-, Handwerks-, und Wirtschaftsgeschichte älterer Zeit / Erwin Volckmann. - Würzburg : Memminger Verlagsbuchhandlung, 1921. - 354 S.

14. Ziesemer W. Preußisches Wörterbuch: Sprache und Volkstum Nordostdeutschlands / Walter Ziesemer. Königsberg, Pr. : Gräfe und Unzer, 19351944. - Bd. I-II. 


\title{
АТРАКТИВНА ФУНКЦЯ ДІАЛЕКТИЗМІВ У ЗАГОЛОВКОВИХ КОМПЛЕКСАХ СУЧАСНИХ IHTEPHET-3MI
}

\author{
Савчук Руслана Любомирівна, \\ кандидат філологічних наук, \\ доцент кафедри журналістики, \\ Прикарпатський національний університет \\ імені Василя Стефаника
}

Сучасний медійний текст активно послуговується різними лінгвістичними засобами, що сприяє стиранню меж між функціональними стилями української мови, адже тяжіє до використання розмовної лексики (діалектизмів, жаргонізмів, просторічних слів). Це зумовлено насамперед його ключовою функцією привернути увагу реципієнтів, вплинути на суспільну свідомість чи підсвідомість.

Перше враження (уявлення) про написане формує назва статті. Саме «від “правильного" номінування тексту залежатимуть погляди, емоції, зацікавлення, вподобання, ціннісні орієнтири адресата, а головне - чи буде прочитаним журналістський матеріал» [1, с. 163].

Так, потужним стилістичним, комунікативно-прагматичним, інтелектуальнокогнітивним та оцінно-образним ефектом у сучасних текстах ЗМІ (назвах статей) наділені лінгвоодиниці, що маніфестують місцевий колорит. Однак, як засвідчує фактичний матеріал, діалектна лексика в заголовкових комплексах досліджуваних інтернет-видань насамперед виконує атрактивну функцію, сприяє приверненню читацької уваги.

Простежимо на деяких прикладах: Усе про срчит, бамбіріння та гачі: на Прикарпатті презентували словник гуиульської говірки («Репортер», 30.12.2019), Ахій, єрчит та гачі: на Прикарпатті презентували словник гуиульської говірки («Версії), 31.12.2019) тощо. Зазначимо: у названих текстах автори все ж подають дефініцію використаних діалектизмів, тому реципієнт, щоб зрозуміти представлені слова, «повинен» прочитати журналістський матеріал. Наприклад: єрчит - варіантна форма слова «єрований», від якого також походять «ярований», «єрчита», «їрчіта», що означає елемент декору кептаря, притаманний Верховинському району (кептар - «гуцульський короткий кожушок без рукавів» [2, с. 45]); бамбіріння («бамбіріні», похідне від «бамбіріня») - замовляння, «бамбірити» - міфологічні слова, вислови, які за народними уявленнями мають чаклунську силу, чинять вплив на когось, лікують хвороби тощо; гачі - штани, вишиті $з$ домотканого полотна й пофарбовані у червоний або чорний колір («Репортер», 30.12.2019).

У публікації інтернет-видання «Версії» представлено тільки пояснення слова aziй (у формі фотографії сторінки зі словника «Гуцульська діалектна лексика та фраземіка в українській художній мові»): агій уживається для висловлення обурення, роздратування («Версії», 31.12.2019). 
Таким чином, бажання читача декодувати смислове наповнення окреслених діалектних слів уже $є$ потужним мотиватором до прочитання тексту статті.

Наведемо ще приклади використання діалектизмів, які у заголовках сучасних інтернет-3МІ реалізують атрактивну функцію: У Франківську показали соборну коляду та гуиульський плєс («Місто», 07.01.2020), Гуиульська коляда і плєс увійшли у національний реєстр нематеріальної культурної спадщини людства ЮНЕСКО («Місто», 14.01.2020). Як бачимо, дешифрування лексеми плєс буде зрозуміле тільки із контексту статті. Слід зазначити, що «плєс є важливою частиною коляди ще з язичницьких часів. Це своєрідний зимовий ритуальний танець. Колядники пританцьовують навколо церкви, а потім - біля хат і під хатами, вітаючи в такий спосіб хати і людей, які там живуть» [3]. Гуцульська коляда 3 плєсом - це насамперед унікальний приклад безперервної співочої традиції у Карпатах. Ця коляда $\epsilon$ втіленням душі гуцулів, частиною їхнього генетичного коду [3].

Частотністю в регіональних медіазаголовках насамперед відзначаються лексичні діалектизми (етнографізми) - бринза (биндза), бануш (банош), трембіта (трембітарі, трембітання), тазда, таздиня, гуиули та ін. Порівняймо: Гуцульська овеча бринза (бриндзя) отримала свідоцтво про реєстрачію географічного зазначення («Місто», 07.12.2019), Без фети, але з гуцульською бриндзею: в Україні набув чинності закон про захист географічних брендів («Версії», 05.01.2020); Міськвиконком дав добро на рекордний бануш в ІваноФранківську («Версії», 02.01.2020), В Івано-Франківську зробили казан для рекордного баноша («Галичина», 10.01.2020); В Івано-Франківську шукають трембітарів для встановлення рекорду з наймасовімого трембітання («Місто», 09.19.2019); Святвечір: як гуцулки-газдині ювелірні «голубиімізинчики» готують («Версії», 06.01.2020), Як порядні галищькі таздині та тазди готуються до Великодня: традииї̈, прикмети та звичаї на Прикарпатті («Версїі», 24.04.2019); Гуцули гуляють: як в Яремче святкують День міста («Галицький кореспондент», 28.07.2019), Автентичний одяг, коляда: гуцули дивували надвірнянців своєю культурою («Версії», 08.01.2020) тощо. Зауважимо, що публіцисти у текстах уникають пояснення використаних етнографізмів, очевидно, спираючись на фонові знання читачів. Декодувати семантичне наповнення репрезентованих мовних одиниць можуть тільки реципієнти, які мешкають на території Прикарпаття, або є вихідцями з цього регіону, іншим читачам доведеться звертатися до словника.

Розглянемо дефініції наведених діалектизмів, звернувшись до словників гуцульських говірок: бринза (биндза) - харчовий продукт, приготовлений із вистояного потовченого і посоленого переважно овечого сиру [2, с. 57]; бануш (банош) - страва $з$ кукурудзяного борошна, зварена на сметані з овечого молока або на свіжих вершках [2, с. 43]; трембітар (трембітаник, трембітачь, трумбітач, тримбіташ) - той, хто грає на трембіті (трембіта - духовний музичний інструмент - дерев'яна труба до 3 метрів довжини, зроблена зі смерекового дерева, обвита березовою корою) [4, с. 188], трембітання - гра на трембіті; тазда - «1. господар; добрий господар; 2. порядна, чесна людина, господар дому, голова родини; 3. чоловік» [4, с. 51], таздиня (таздині) - «1. 
господиня; 2. порядна чесна жінка; 3. дружина» [4, с. 51]; гуцули - етнографічна група українців, які живуть у гірській місцевості західної України [2, с. 95]. Таким чином, використання діалектної лексики у досліджуваних назвах спричинене прагненням журналістів зацікавити цільову аудиторію, продемонструвати мовну оригінальність, відтворити етноспецифіку регіону Прикарпаття.

Отже, здійснений аналіз дозволяє констатувати: діалектизми у складі медіазаголовків виконують насамперед атрактивну функцію, служать актуалізаторами уваги реципієнта. Вдале вербальне оформлення заголовка сучасного медійного тексту здатне впливати на свідомість реципієнта, скеровувати його думки, погляди в русло авторських установок, а головне підвищити читабельність тексту.

\section{Список літератури:}

1. Савчук Р.Л. Стилістичні засоби у заголовках сучасних медіатекстів: психолінгвістичний аспект. Актуальні питання гуманітарних наук: міжвузівський збірник наукових праць молодих вчених Дрогобицького державного педагогічного університету імені Івана Франка / [редакт.-упорядн. М. Пантюк, А. Душний, І. Зимомря]. Дрогобич : Видавничий дім «Гельветика», 2020. Вип. 34. Том 4. С. 161-170. DOI https://doi.org/10.24919/2308-4863/34-4-24

2. Гавука П. Д. Тлумачний словник гуцульських говірок. Косів : Писаний Камінь, 2017. 296 с.

3. Криворівня. Гуцульська коляда попри заборони. Ukrä̈ner. 13 травня 2019 p. URL: https://ukrainer.net/kryvorivnia/

4. Гуцульські говірки : короткий словник / Iн-т українознавства ім. І. Крип'якевича НАН України ; уклад.: Г. Гузар, Я. Закревська, У. Єдлінська, В. Зеленчук, Н. Хобзей ; відп. ред. Я. Закревська. Львів : 1997. 232 с.

Bepciï. URL: http://versii.if.ua/

\section{Інтернет-ресурси:}

Галицький кореспондент. URL: http://gk-press.if.ua/

Галичина. URL: http://www.galychyna.if.ua/

Місто. URL: https://mi100.info

Репортер. URL: http://report.if.ua/ 


\title{
ДО ПИТАННЯ САНСКРИТСЬКОГО ПОХОДЖЕННЯ ЮАНСЬКОї ДРАМИ ЦЗАЦЗЮЙ
}

\author{
Shcherbakov Yaroslav, \\ $\mathrm{PhD}$, senior lecturer, \\ Borys Grinchenko Kyiv University
}

Питання індійського походження китайської драми залишалася малодослідженою до початку XX ст. Вперше це питання було висвітлено у роботі Сюй Дішаня «Вплив принципів будови санскритської драми на китайську», що було опубліковане у 1927 році [1]. Статтю Сюй Дішаня значною мірою можна назвати прямим продовженням наукової роботи Ван Говея «Історія сунського та юанського театру» [2], що побачила світ у 1912 році, за рік після падіння останньої китайської імперії Цін. За часів маньчжурської колоніальної імперії, найкращими представниками якої були імператори Кансі, Юнчжен i Цяньлун, китайські науковці приділяли не надто багато уваги жанрам народної літератури, мабуть, за виключенням китайського народного роману та епічних сказань центральної Азії. Аналіз театральних постанов та театралізованих дійств, лібрето та сюжетів вважався недостойним високого звання літератора, як i в Свропейських країнах за часів раннього просвітництва. Зрештою, XIX ст. століття двобію романтики та реалізму у літературах Свропейських країн, стало століттям, коли Європа випередила Китай, і вже не європейській вільнодумець Вольтер змальовував імперію Цін як ідеальну країну, а вчення Конфуція як ідеальну релігію, а китайський автор став поглинутий пошуком коріння народної прози. Китайський театр та драматургія виявилися прогалиною як для азійського, так і для європейського науковця. Ван Говей у 1912 році спробував дещо ліквідував цю прогалину, написавши роботу «Історія сунського та юанського театру». Ця наукова праця була написана мовою веньянь, носила реферативний характер, у роботі найстараннішим образом були зібрані усі відомості щодо історії китайського театру та драми, які можна знайти у давньокитайській літературі та історичних хроніках. Але це дослідження не розкривало найголовнішого питання: чому китайська літературна драма з'явилася настільки пізно для щонайменше шести-тисячорічної китайської цивілізації, лише у XIIXIII ст. за доби імперій Цзінь та Юань, коли територія центральної та східної Азії була зруйнована через загарбницьку війну Чингісхана ? Чому структура Юанської драми цззазцюй була одразу настільки складною, драми включали у 
себе від 4 до 6 актів дії, пролог та епілог ? Чому понад 500 драм изаизюй були написані в умовах розваленої економіки та суспільства ?

Єдиною можливою відповіддю на це питання могло бути лише запозичення самої ідеї літературної драми з зовні, з іншої етно-культурної сфери, але якщо таке запозичення було, то як, чому і навіщо воно відбувалося ?

3 точки зору Сюй Дішаня [1], на формування Юанської драматургії сильний вплив мала санскритська драма. Санскритська драма виникла одночасно 3 буддизмом Махаяни на мержі I-II століття, та через канали поширення буддизму Махаяни розповсюдилася на території Східного Туркестану за династії Хань. Загадаємо, що ранній китайський буддизм носить назву саме Хань-буддизм. Дослідження Сюй Дішаня було першою науковою відповіддю у китайській науці на видатне археологічне відкриття німецького вченого Генріха Людерса. Людерс в 1911 році знайшов сувої з текстами санскритських драм на території Східного Туркестану та видав їх у Берліні в 1911 році, у книзі Bruchstückebuddhistischer Drame : H.Lüders, Bruchstückebuddhistischer Dramen. KleinereSanskrit-Texte». Серед буддійських текстів повністю збереглися тексти Асвагхоши Шаріпутрапракарана, драма Кальпанамандітика Кумаралати та три тексти без назви [3]. Мовою оригіналу текстів була індійська мова Брахмі доби Гупта. Ця знахідка говорить про наявність санскритської драматургії на території Китаю у першій половині I тис. д.н.е.

Наступною археологічною знахідкою, що говорить про наявність санскритської драматургії на території Китаю у зазначений період $є$ археологічна знахідка, яка була здійснена на території автономного району Східний Туркестан у місті Хамі в 1957 році. Це була повна версія тексту жанру санскритської драми натака під назвою Майтрісаміті [4]. Невеликі фрагменти цього тексту знайшов на початку століття французький археолог Ле Кок. Отже, санскритські драми, далеко не поодинокі, на території Китаю тих часів були.

Розвиток санскритської теорії походження китайської драми пропонує науковець Бен Ляо у дослідженні «Від санскритської драми до драми суизян...»[5]. Вчений вводить у науковий оббіг наступну версію походження китайської драми: санскритська драматургія мала вплив на драму тохарською мовою, остання вплинула на уйгурську драматичну традицію, а уйгурська драма вплинула на китайську літературну драму. Факти впливу уйгурської традиції на китайську ще за доби Тан наводить Айданьму Юйсаінь у статті «уйгурський театр» [6].

Теорію індійського походження китайської драми розвиває видатний дослідник Чжен Чженьдо [7,8], який говорить про паралелі в амплуа індійської та китайської драми, зокрема, жіноче санскритське амплуа Nayika паралельне 
амплуа дань, мають свої паралелі і чоловічі амплуа изін та шен. Структура драми изаизюй є паралельною структурі санскритської драми натака.

Отже, санскритський вплив на формування китайської драми изаџзюй ми можемо не тільки теоретично вбачати, але і вважати доведеним. А роль буддійського вчення у поширенні Юанської драми стала можливою за часів монгольської Юанської імперії, «ідеологією» якої було буддійське вчення.

Більш детально про результати проведеного дослідження можна прочитати у моїй авторській книзі-монографії «Китайський буддизм та драма цзащзюй доби Юань»

\section{References:}

1. Xǔdeshān. (1927). "fàn jù tǐlì jí qí zài hànjù shàng de diăn diăndī dī "xiăoshuō yuè bào", 17,1 [In Chinese]

2. Wángguówéi. (2001) Wángguó wéi wénxué lùn zháo sān zhǒng «sòng yuán xìqǔ kăo».China, Běijīng. Shāngwù yìn shūguăn. [In Chinese]

3. Lüders, H. (1911). Bruchstückebuddhistischer Dramen. Kleinere Sanskrit-Texte [In German]

4. Gěngshìmín (1982) "gŭdài wéiwú'ěr yǔ fójiào yuánshǐ jùběn 〈mílè huìjiàn jì〉 (hāmì xiěběn) yánjiū”.Wenshi,12,211-226. [In Chinese]

5. Liào bēn. (1995) nián Cóng fàn jù dào sú jiăng—duì ȳ̄ zhǒng wénhuà zhuănxíng xiànxiàng de pōuxī. wénxué yíchăn, 3,65-77 [In Chinese]

6. Ài tăn mù•yù sài yīn, lián mǐn. 1999 Wéiwú'ěr zú xìjù yìshù xúnlǐ —xiàn gěi guóqìng wǔshí zhōunián/ ài tăn mù•yù sài yīn, lián mǐn. xīnjiāng yìshù,5,118 [In Chinese]

7. Zhèngzhènduó. (2009).Chātú běn zhōngguó wénxué shǐ. Shàng.Běijīng, China: Dāngdài shìjiè chūbăn shè. [In Chinese]

8. Zhèngzhènduó. (2009).Chātú běn zhōngguó wénxué shǐ. Xià.Běijīng, China: Dāngdài shìjiè chūbăn shè. [In Chinese]

9. Shcherbakov, Y.I. (2019) The theory of the Indian Sanskrit origin of the Chinese drama of Zhuji in the context of the historical studies of the Oriental Culture. National Academy of Managerial Staff of Culture and Arts Herald - National Academy of Managerial Staff of Culture and Arts Herald, 2, 471-474. [In Ukrainian] 


\title{
FIBONACCI SEARCH METHOD TO SELECT LEARNING RATE FOR GRADIENT DESCENT OPTIMIZATION ALGORITHM
}

\author{
Solovei Olga, \\ Ph.D., Associate Professor \\ Kyiv University of Civil Building and Architecture
}

Introduction. Gradient descent is an optimization algorithm best used when analytical approach could not be used to solve minimization problem [1]. However, gradient descent algorithm employs a hyperparamer learning rate (further $\lambda$ ): when $\lambda$ is set incorrectly - the optimal solution may not be found.

Recommendations on how to select $\lambda$ in gradient descent optimization algorithm includes:1) learning rate annealing - start with a large learning rate and if the training criterion diverges, try again with 3 times smaller learning rate [2]; 2) learning rate decay $-\lambda$ is decreased according to an exponential or quadratic function of the time steps [3]; 3) scaling learning rates so that the average update is on the order of 1/1000th and some others [4].

All the mentioned methods are belonging to hyperparameters optimization algorithms [5] with the same problem to notice - the "right" value for $\lambda$ can be missed when the wrong rate is selected for new $\lambda$.

In current paper, it is proposed to consider the usage of divide and conquer algorithms, in particular Fibonacci search [6], to select $\lambda$ to be used with gradient descent optimization algorithm as an approach that allows to avoid the problem of the mentioned hyperparameters optimization algorithms.

Goal. Evaluate the feasibility to use Fibonacci search technique to find a learning rate $\lambda$ to be used with gradient descent optimization algorithm to solve unimodal linear regression problem.

Main part. The problem to study is formulated as: it is required to find $\lambda \in[0 ; 1]$ that guarantees the adjustment of linear regression parameters $\theta$ per formula (1) in order to achieve the lowest cost $J(\theta)$ per formula (2)

$$
\begin{gathered}
\theta_{j}=\theta_{j}-\alpha \frac{1}{m} \sum_{i=1}^{m}\left(\theta_{0}+\theta_{1} \cdot x_{[1][i]}-y_{i}\right) \cdot x_{i} \\
J(\theta)=\frac{1}{2 m} \sum_{i=1}^{m}\left(\theta_{0}+\theta_{1} \cdot x_{[1][i]}-y_{i}\right)^{2}
\end{gathered}
$$

where $x_{[1]}$ - a vector with observed values of independent variable; $y$ - a vector with observed values of dependent variable; $m$ - the size of vectors $x_{i} ; y_{i}$.

The evaluation of the feasibility to be performed through the sequence of the steps: 1) find $\lambda$ by learning rate annealing method; 2 ) find $\lambda$ by Fibonacci search technique; 
3) Compare cost functions and the quality of built regression models received as a result of the completion of step1 and step2.

The data set to be used in the current work is presented in columns: $x_{i}$ and $y_{i}$ from Table1.

Learning rate annealing method: the array of $\lambda$ includes values from 1 to 0 where each $\lambda_{i}=1 / 10 \cdot \lambda_{i-1}$. The gradient descent method is ran for each $\lambda_{i}$ to calculate the linear regression model parameters. The cost function (Fig 1) for $\lambda=$ $1,0.1,0.01,0.001,0.0001,0.00001,0.000001,0.0000001,0.00000001,0.000000001,0$
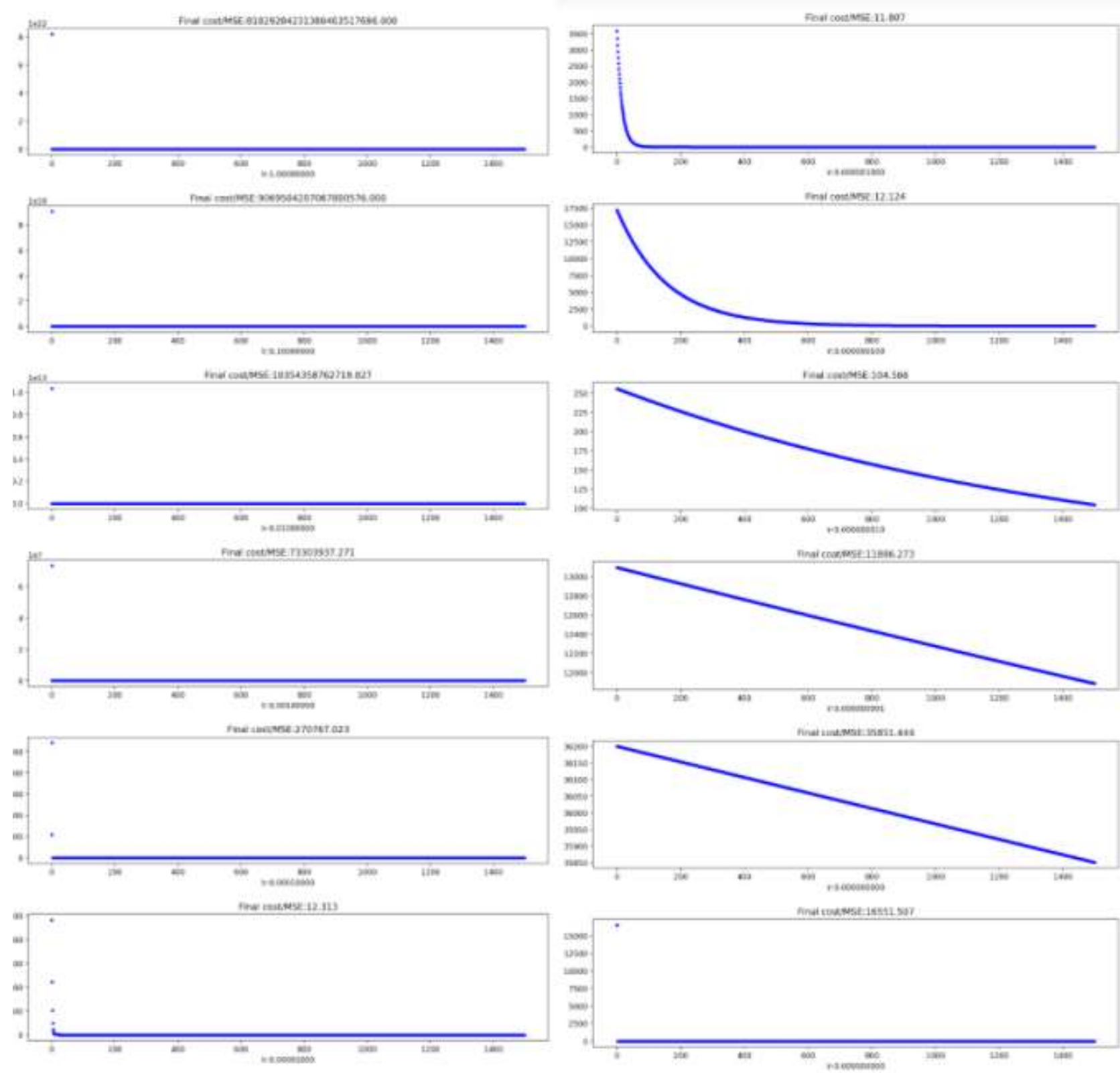

Figure 1. Cost function curves

show that smooth decrease of cost function had been achieved when $\lambda=0.000001$, the corresponding final value of cost is $J(\theta)=11.8$. Built linear regression model is 
described by equation $y=0.519+0.359 \cdot \mathrm{x}$ and has the determination rate equal to 0.93 (Table1) which is a good quality of prediction model.

Table 1

$R^{2}$ score for calculated $\theta_{0}=0.519 ; \theta_{1}=0.359$ and learning rate $\alpha=1 \mathrm{E}-05$

\begin{tabular}{|c|c|c|c|c|c|c|}
\hline & $x_{i}$ & $y_{i}$ & $\theta_{0}+\theta_{1} \cdot x_{i}$ & $\left(\theta_{0}+\theta_{1} \cdot x_{i}-y_{i}\right)^{2}$ & $\left(y_{i}-\frac{1}{n} \sum_{i=1}^{n} y_{i}\right)^{2}$ & $R^{2}$ \\
\hline 1 & 100 & 38 & 36.419 & 2.499 & 600.25 & \\
\hline 2 & 132 & 43.2 & 47.907 & 22.156 & 372.49 & \\
\hline 3 & 150 & 52.4 & 54.369 & 3.877 & 102.01 & \\
\hline 4 & 173 & 67.5 & 62.626 & 23.755 & 25 & \\
\hline 5 & 198 & 64 & 71.601 & 57.775 & 2.25 & \\
\hline 6 & 218 & 78.4 & 78.781 & 0.145 & 252.81 & \\
\hline 7 & 240 & 94 & 86.679 & 53.597 & 992.25 & \\
\hline$\frac{1}{n} \sum_{i=1}^{n} y_{i}$ & & 62.5 & & & & \\
\hline$\sum$ & & & & 163.805 & 2347.06 & 0.930 \\
\hline
\end{tabular}

Fibonacci search technique. Set interval for possible values of learning rate to be $L_{0}=[0,1]$ and the smallest interval to be $l=1 E-6$. Calculate the size of array with Fibonacci numbers to be $N=31$, where $F_{n}$ be the smallest number in array which is bigger than $\frac{\left|L_{0}\right|}{l}$. Calculate initial values for learning rates $\lambda_{k}=a_{k}+\frac{F_{N-k-1}}{F_{N-k+1}} \cdot\left(b_{k}-a_{k}\right)$; $\lambda_{k}^{\prime}=a_{k}+\frac{F_{N-k}}{F_{N-k+1}} \cdot\left(b_{k}-a_{k}\right)$. Run the gradient descent method with $\lambda_{k}$ and $\lambda_{k}^{\prime}$, compare the received cost $J\left(\lambda_{k}, \theta\right)$ and $J\left(\lambda_{k}^{\prime}, \theta\right)$. When $J\left(\lambda_{k}, \theta\right) \leq J\left(\lambda_{k}^{\prime}, \theta\right)$ then set $b_{k}=\lambda_{k}^{\prime}$ else set $a_{k}=\lambda_{k}$. Repeat calculation until $b_{k}-a_{k}>\frac{\left|L_{0}\right|}{l}$. From calculation results in Table2, can be seen that the lowest value of cost function $J\left(\lambda_{k}, \theta\right)=11.2$ was achieved when $\lambda=0.00000368$. Built linear regression model is described by equation $y=-0.662+0.365 \cdot \mathrm{x}$ and the quality corresponds to determination rate equal to 0.932 (Table3)

Table 2

Learning rate selected by Fibonacci search method

\begin{tabular}{|c|l|l|l|c|c|c|}
\hline $\mathrm{K}$ & \multicolumn{1}{|c|}{$a_{k}$} & \multicolumn{1}{c|}{$b_{k}$} & $\lambda_{k}$ & $\lambda_{k}^{\prime}$ & $J\left(\lambda_{k}, \theta\right)$ & $J\left(\lambda_{k}^{\prime}, \theta\right)$ \\
\hline 1 & 0 & 1 & 0.38196601 & 0.61803399 & $1.29 \mathrm{E}+21$ & $1.78 \mathrm{E}+21$ \\
\hline 2 & 0 & 0.38196601 & 0.14589803 & 0.23606798 & $3.66 \mathrm{E}+19$ & $5.11 \mathrm{E}+19$ \\
\hline 3 & 0 & 0.14589803 & 0.05572809 & 0.09016994 & $3.04 \mathrm{E}+16$ & $1.52 \mathrm{E}+17$ \\
\hline 4 & 0 & 0.05572809 & 0.02128624 & 0.03444185 & $4.62409 \mathrm{E}+15$ & $3.04 \mathrm{E}+16$ \\
\hline
\end{tabular}


Continuation of Table 2

\begin{tabular}{|c|c|c|c|c|c|c|}
\hline $\mathrm{K}$ & $a_{k}$ & $b_{k}$ & $\lambda_{k}$ & $\lambda_{k}^{\prime}$ & $J\left(\lambda_{k}, \theta\right)$ & $J\left(\lambda_{k}^{\prime}, \theta\right)$ \\
\hline 5 & 0 & 0.02128624 & 0.00813062 & 0.01315562 & $\begin{array}{l}8.68432 \mathrm{E}+1 \\
2\end{array}$ & $5.30978 \mathrm{E}+14$ \\
\hline 6 & 0 & 0.00813062 & 0.00310562 & 0.005025 & $\begin{array}{l}89427850.2 \\
1\end{array}$ & $1.32356 \mathrm{E}+13$ \\
\hline 7 & 0 & 0.00310562 & 0.00118624 & 0.00191938 & $\begin{array}{l}470550868 . \\
9\end{array}$ & $8.65216 \mathrm{E}+11$ \\
\hline 8 & 0 & 0.00118624 & $\begin{array}{l}0.00045310 \\
0\end{array}$ & 0.00073314 & 519647439 & 2844028050 \\
\hline 9 & 0 & 0.0004531 & $\begin{array}{l}0.00017307 \\
0\end{array}$ & 0.00028003 & 1151551.27 & 47419141.5 \\
\hline 10 & 0 & 0.00017307 & $\begin{array}{l}0.00006611 \\
0\end{array}$ & 0.00010696 & 14755.91 & 63905.19 \\
\hline 11 & 0 & 0.00006611 & $\begin{array}{l}0.00002525 \\
0\end{array}$ & 0.00004086 & 11.45 & 11.65 \\
\hline 12 & 0 & 0.00002525 & $\begin{array}{l}0.00000964 \\
0\end{array}$ & 0.00001561 & 11.34 & 12.51 \\
\hline 13 & 0 & 0.00000964 & $\begin{array}{l}0.00000368 \\
0\end{array}$ & 0.00000596 & 11.2 & 12.42 \\
\hline 14 & 0 & 0.00000368 & $\begin{array}{l}0.00000141 \\
0\end{array}$ & 0.00000227 & 11.94 & 11.37 \\
\hline 15 & $\begin{array}{l}0.0000022 \\
7\end{array}$ & 0.000003680 & $\begin{array}{l}0.00000281 \\
0\end{array}$ & 0.00000314 & 11.74 & 11.59 \\
\hline
\end{tabular}
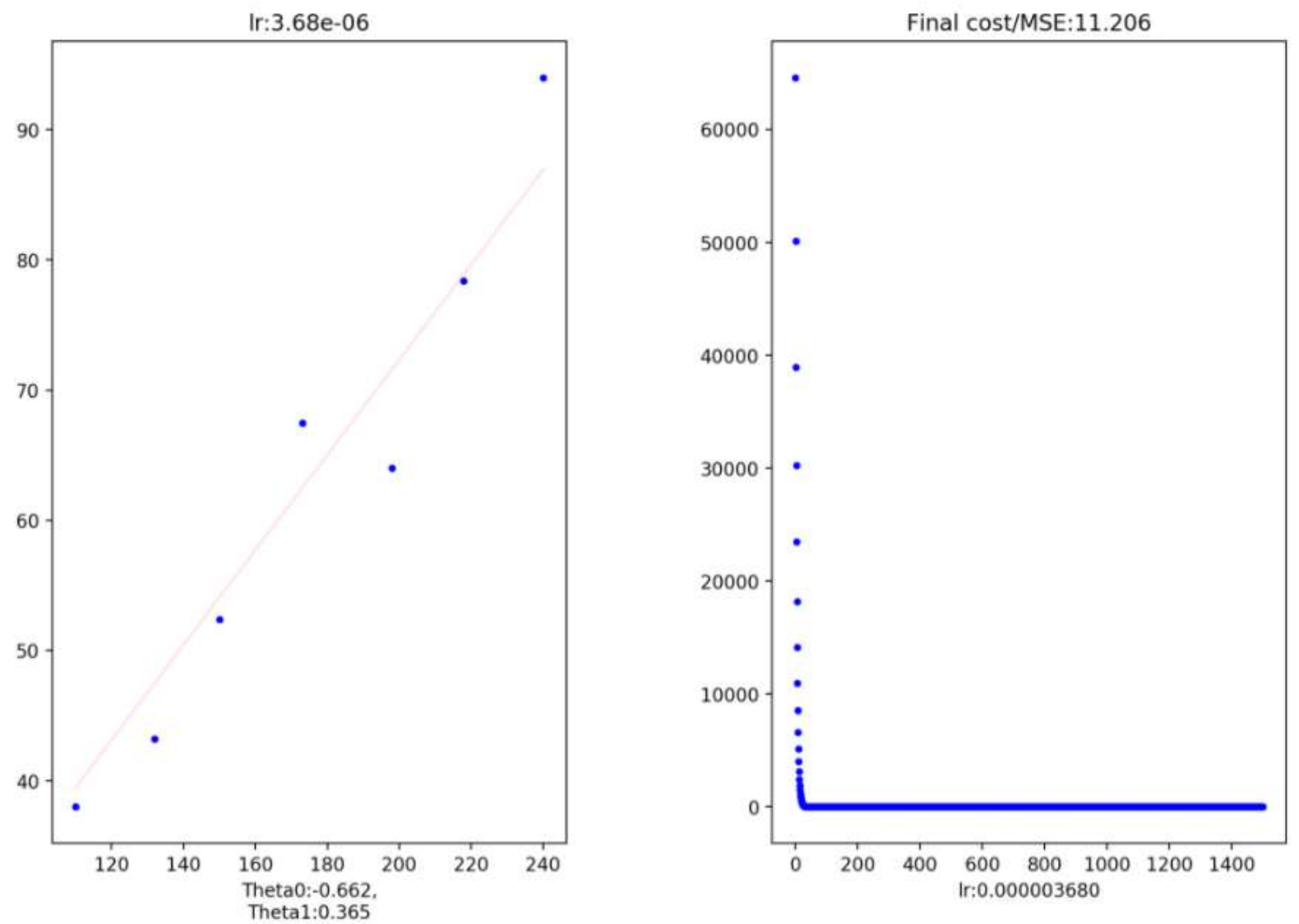

Figure 2. Prediction linear model and cost function curve for $\lambda=0.00000368$ 
Table 3

$R^{2}$ score for calculated $\theta_{0}=-0.662 ; \theta_{1}=0.365$ and learning rate $\lambda=0.0000036$

\begin{tabular}{|l|l|l|l|l|l|l|}
\hline & \multicolumn{1}{|c|}{$x_{i}$} & & $\theta_{0}+\theta_{1} \cdot x_{i}$ & $\left(\theta_{0}+\theta_{1} \cdot x_{i}-y_{i}\right)^{2}$ & $\left(y_{i}-\frac{1}{n} \sum_{i=1}^{n} y_{i}\right)^{2}$ & $R^{2}$ \\
\hline 1 & 100 & 38 & 35.838 & 4.674 & 600.25 & \\
\hline 2 & 132 & 43.2 & 47.518 & 18.645 & 372.49 & \\
\hline 3 & 150 & 52.4 & 54.088 & 2.849 & 102.01 & \\
\hline 4 & 173 & 67.5 & 62.483 & 25.170 & 25 & \\
\hline 5 & 198 & 64 & 71.608 & 57.881 & 2.25 & \\
\hline 6 & 218 & 78.4 & 78.908 & 0.258 & 252.81 & \\
\hline 7 & 240 & 94 & 86.938 & 49.871 & 992.25 & \\
\hline$\frac{1}{n} \sum_{i=1}^{n} y_{i}$ & & & & & & \\
\hline$\sum$ & & 62.5 & & & 2347.06 & 0.932 \\
\hline
\end{tabular}

Conclusions. The calculation results from Table 2 shows that with 13 interactions of Fibonacci search had been found learning rate $\lambda$ which allowed to achieve the lowest value of cost function. The way learning rate $\lambda$ is decreased in each iteration showed that the "right" value of $\lambda$ could not be missed.

The determination score of regression model built with $\lambda$ found by Fibonacci search is slightly heigher compare to determination score of regression model built with $\lambda$ defined by learning rate annealing method, which means the gradient descend solved optimization problem slightly better with $\lambda$ found by Fibonacci search method.

The aforementioned allows to propose the usage of Fibonacci search algorithm for selection of learning rate parameter $\lambda$ in gradient descent optimization algorithm when it is used to solve unimodal linear regression problem.

\section{References:}

1. An Introduction to Optimization, 4th Edition by Stanislaw H. Zak; Edwin K. P. Chong. Published by Wiley, 2013.

2. Bengio, Y. (2011). Deep learning of representations for unsupervised and transfer learning. In JMLR W\&CP: Proc. Unsupervised and Transfer Learning.

3. Hands-On Convolutional Neural Networks with TensorFlow by Giounona Tzanidou; Iffat Zafar; Nimesh Patel; Leonardo Araujo; Richard Burton. Published by Packt Publishing, 2018

4. Cho, K., Raiko, T., and Ilin, A. (2011). Enhanced gradient and adaptive learning rate for training restricted boltzmann machines. In ICML'2011, pages 105-112.

5. The Machine Learning Workshop - Second Edition by Hyatt Saleh.Published by Packt Publishing, 2020

6. Engineering Optimization, 5th Edition, by Singiresu S. Rao. Published by Wiley, 2019 


\section{IS POLITICAL POWER CONFLICTUAL OR CONSENSUAL?}

Andrushko Vladyslav,

Ph.D. student Taras Shevchenko National University of Kyiv

There is a growing body of literature that recognizes the importance of political power understanding. It is also worth mentioning that definition of political power is a classic problem in social sciences because of huge amount of scientific approaches to it. Actually, the concept of Power is a heart of our understanding of social processes. That's why it is a major area of interest within the field of sociology, psychology, linguistic, law, political anthropology, structuralism and other humanities. More recently, literature has emerged that offers contradictory findings about this ambiguous phenomenon and puts it into multidisciplinary discourse.

So, how should we define power?

Looking back at history of the term, we come to conclusion that the first thought about Power appeared in Ancient Greece due to well-known thinkers Plato and Aristotle, who used to consider the power as the ability of polis citizens to make political decisions. The Power was associated with God in the Middle Ages and with law in the Age of Enlightenment. As a result of such way of thinking, now we have a structured legal system and three branches of state power with checks and balances systems. In the $19^{\text {th }}$ century the power was perceived as a psychological or even socioeconomic concept. The classic example of the tendency is Z. Freud, who described Power through his "libido" theory. Actually, F. Nietzsche also should be mentioned in this context, as well as he illustrated this point clearly in his "will to power", which he saw as the domination of other humans as much as the exercise of control over one's environment. Regarding socio-economic view on power, we cannot avoid mentioning K. Marx and F. Engels as famous philosophers who developed a concept of "labour power" and created a new way of understanding power as a priori conflict social phenomenon.

Since the beginning of $20^{\text {th }}$ century the big number of power concepts appeared. According to K. Dowding`s research [1], each of them can be distinguished as conflictual (power always involves the clash of interests or plans and what one gains another loses), consensual (power is about bringing people together in order to gain common goals) or combined (the nature of power both conflictual and consensual). Let`s consider the most significant power definitions in the context of K. Dowding`s classification. 


\section{Defining political power (conflictual, consensual, combined)}

\begin{tabular}{|c|c|c|}
\hline Author & Definition & Generalization \\
\hline M. Weber [2] & $\begin{array}{l}\text {... "Power as the chance that one individual in a } \\
\text { social relationship can achieve his or her own will } \\
\text { even against the resistance of others"... }\end{array}$ & Conflictual \\
\hline R. Dahl [3] & $\begin{array}{l}\text {.."A has power over B to the extent that he can get } \\
\text { B to do something that B wouldn't otherwise do"... }\end{array}$ & Conflictual \\
\hline S. Lukes [4] & $\begin{array}{l}\ldots \text { "I have defined the concept of power by saying } \\
\text { that A exercises power over B when A affects B in a } \\
\text { manner contrary to B`s interests"... }\end{array}$ & Conflictual \\
\hline T. Parsons [5] & $\begin{array}{l}\text {... "Power is the capacity to mobilize the resourses of } \\
\text { the society for the attainment of goals for which a } \\
\text { general public commitment has been made"... }\end{array}$ & Consensual \\
\hline H. Arendt [6] & $\begin{array}{l}\text {.. "Power is the very condition enabling a group of } \\
\text { people to think and act in terms of the means end } \\
\text { category"... }\end{array}$ & Consensual \\
\hline S. Clegg [7] & $\begin{array}{l}\text {... "Power as being about the outcome issues enabled } \\
\text { by the rule of substantive rationality which is } \\
\text { temporally and institutionally located"... }\end{array}$ & Combined \\
\hline M. Faucault [8] & $\begin{array}{l}\text {.."Power is constituted through accepted forms of } \\
\text { knowledge, scientific understanding and truth. Truth } \\
\text { is a thing of this world. It is produced only by virtue } \\
\text { of multiple forms of constraint, and it induces regular } \\
\text { effects of power"... }\end{array}$ & Combined \\
\hline K. Dowding [9] & $\begin{array}{l}\text {.."Outcome power is the ability of an actor to bring } \\
\text { about or help bring about outcomes; but social power } \\
\text { is the ability of an actor to change the incentive } \\
\text { structures of other actors in order to bring about } \\
\text { outcomes"... }\end{array}$ & Combined \\
\hline
\end{tabular}

Associated with the conflict vs. consensus cleavage is whether power should be defined in terms of 'power over' where the 'real' meaning of power is the power of one agent over another (or the system over agents); or whether the underlying account of power should be 'power to', where power is the power to attain what one aims for and 'power over' is simply a subset, a means by which some agents attain what they aim for [9].

But according to P. Pansardi, power to and power over, despite what most of the contemporary power literature implies, cannot be described as two distinct concepts of power. They are, by contrast, best understood as two different aspects of a single, unified concept of power, which is intrinsically social and, as a consequence, able to account for the (implicit or explicit) relationality which every attribution of power involves when we talk of power in a society [10].

We agree with the statements given above. Eventually, it is worth mentioning that power shapes have been changing from day to day and there is not the only one universal approach in modern scientific discourse to describe them. 


\section{References}

1. Dowding, K. (2012). Why should we care about the definition of power? Journal of Political Power, 5(1), 119-135.

2. Beetham, D. (2018). Max Weber and the theory of modern politics. John Wiley $\&$ Sons.

3. Dahl, R. A. (1957). The concept of power. Behavioral science, 2(3), 201-215.

4. Lukes, S. (2004). Power: A radical view. Macmillan International Higher Education.

5. Parsons, T. (1963). On the concept of political power. Proceedings of the American philosophical society, 107(3), 232-262.

6. Penta, L. J. (1996). Hannah Arendt: On Power. The Journal of Speculative Philosophy, 210-229.

7. Clegg, S. R. (1989). Frameworks of power. Sage.

8. Foucault, M. (2019). Power: the essential works of Michel Foucault 1954-1984. Penguin UK.

9. Dowding, K. (2019). Rational choice and political power. Policy Press.

10. Pansardi, P. (2012). Power to and power over: two distinct concepts of power?. Journal of Political Power, 5(1), 73-89. 


\section{GEORGIEN IM ÖSTLICHEN \\ PARTNERSCHAFTSSYSTEM}

Vaja Shubitidze, $\mathrm{PhD}$ in Political Science, professor Georgian Technical University

Otar Davitashvili, $\mathrm{PhD}$ in History, professor Georgian Technical University

Edisher Japharidze,

$\mathrm{PhD}$ in Political Science, professor Georgian Technical University

Zum ersten Mal fangen die Beziehungen zwischen EU-Union und Georgien in den 1991-1992 an. Nachdem die Sowjetunion zerlegt wurde und Georgien als einen unabhängigen Staat formulierte. 1996 wurde in Luxemburg eine Vereinbarung über Partnerschaft und Zusammenarbeit (PCA) zwischen Georgien und EU-Union unterschrieben, was in sich Anfang ständiger institutioneller Beziehungen mit den modernen unabhängigen Staaten, zwecks Entwicklung beidseitiger Beziehungen und politischer Dialog meinte. Nach der Entscheidung von EU-Rat, ab 14. Juni 2004 nimmt Georgien bei der Nachbarpolitik von EU (ENP) aktiv teil. Europäische Nachbarpolitik (ENP) stellt ein Hauptmechanismus der Zusammenarbeit mit den Nachbarstaaten, liegend südlich von EU-Union dar.

Bei der Nachbarpolitik nehmen 16 Staaten teil (Algerien, Aserbaidschan, Weißrussland, Ägypten, Jordanien, Israel, Libanon, Libyen, Moldawien, Marokko, Palästina, Georgien, Syrien, Armenien, Tunesien und Ukraine). Hauptzweck von Nachbarpolitik besteht aber an Unterstützung der Stabilität, Sicherheit und Entwicklung zwischen EU-Union und Nachbarstaaten.

Durch die Entwicklung umfassender Reformen und Unterzeichnung einer Assoziierungsvereinbarung mit EU-Union im 2014, nahm Maßstabe der EU-Hilfe wesentlich zu. Moderne Modalitäten der EU-Hilfe nahm auch in Georgien zu, die Assoziierungsvereinbarung ermöglichte uns an beidseitigen Formaten der EU-Hilfe, zwecks Entwicklung des Staates und Näherung mit den EU-Standards teilzunehmen.

Östliche Partnerschaft (ENP) - Initiative, als ein neues Format der Zusammenarbeit mit den östlichen Nachbarstaaten der EU-Union (Georgien, Armenien, Aserbaidschan, Moldawien, Weißrussland, Ukraine), wurde zum ersten Mal durch Schweden und Pollen entwickelt, deren Ziel daran bestand in Hinsicht EU-Partner Durchführung EUNachbarpolitik zu unterschützen und ihre östliche Maßstäbe zu stärken. EU-Ausschuss 
veröffentlichte eine Kommunikation über die „Ost-Partnerschaft“ im Dezember 2008, aber am 19. März 2009 hat man auf der Sitzung von EU-Rat sie festgestellt.

Man muss erwähnen, dass georgische Regierung Richtung stufenweiser Integration in die EU-Union durch die volle Nutzung der neuen Möglichkeiten ,der Ostpartnerschaft" wieder aktiv arbeitet, was eine sehr wichtige Perspektive für endgültige Integration von Georgien in die EU-Union darstellt.

Die erfolgreiche Umsetzung der Ziele der Nachbarschaftspolitik ermöglichte es, die Beziehungen Georgiens zur Europäischen Union zu vertiefen und ein Assoziierungsabkommen zu schließen. Im Rahmen der Östlichen Partnerschaft als Sonderrichtung der Europäischen Nachbarschaftspolitik haben Georgien und die Europäische Union am 27. Juni 2014 das Assoziierungsabkommen unterzeichnet, das am 1. Juli 2016 in Kraft trat.

EU-Ausschuss veröffentlichte am 9. Februar 2021 jährliche Rechnung über die Assoziierungsvereinbarung seitens Georgien während 2020, und zwar: trotz der CovidPandemie ist Georgien dynamisch dem europäischen Weg gefolgt und hat seine Verpflichtungen aus dem Assoziierungsabkommen weiterhin erfolgreich erfüllt, inzwischen Näherung von Georgien mit der EU-Gesetzgebung und EU-Standards der Menschenrechtenschutz. EU-Union bestätigt offen ihre Unterstützung in den international anerkannten Grenzen gegen die territoriale Einigung des Staates und spricht über ihre aktive Teilnahme an einem Prozess der Konfliktlösung.

$\mathrm{Ab}$ 28. März 2017gilt für georgische Bürger „VISA-Liberalisierung“ - Regime der Reise ohne Visum in die Schengener Zone der EU-Union. Es war noch einen Schritt für die endgültige Integration von Georgien nach Europa.

Nachdem di georgische Regierung nach den von der OSZEanerkannten Wahlen am 31 Oktober 2020 angekundigt hatte, dass Georgien bis 2024 die Vollmitgliiedschaft in der Europaischen Union beantragen werde, verstarkete Russland durch seine ,funfte kolumne" den politischen, wirtschaflichen und militarischen Druck auf Georgian, Schaffung und Unterbrechung der integrationen des Landers in Europe, die bis heute andauert. Deshalb Die EU muss Georgien und seine fragile Demokratie schutzen. Erhohen sie den Druck auf Russland und leisten sie umfassende Hilfe fur Georgien, damiT Reset nicht ganc Georgien und seine nachste Annexion einnimmt.

\section{References:}

1. Walter Kaufmann. Der weite Weg zur $>$ Zivilgesellschaft $<\ll$, in: Aus Politik und Zeitgeschichte, (23.3.2009) 13, S. 12-18, hier besonders S. 17f;

2. Susan Stewart. The Role of International and Local NGOs in the Transformation of the Georgian- Abkhazian Conflict«, in: The Global Review of Ethnopolitics,

(März-Juni 2004) 3-4, S. 3-22

3. Annegret Bendiek. Stiftung Wissenschaft und Politik Deutsches Institut für Internationale Politik und Sicherheit Wie effektiv ist die Europäische Nachbar-

schaftspolitik? S 24 .September 2008 Berlin 
4. Michael H. Kohrs, »Geschichte als politisches Argument. Der $>$ Historikerstreit< um Berg-Karabach«, in: Fikret Adanir/ Bernd Bonwetsch (Hg.), Osmanismus, Nationalismus und der Kaukasus, Wiesbaden 2005, S. 43-63;

5. H.Kaufmann, Der weite Weg zur Zivilgesellschaft, S. 17.

6. Jürgen Gerber, Georgien. Nationale Opposition und kommunisti`sche Herrschaft seit 1956, Baden-Baden 1997, S. 15.

7. Vgl. John Mackinlay/Evgenii Sharov, »Russian Peacekeep-ing Operations in Georgia «, in: John Mackinlay/Peter Cross (Hg.), Regional Peacekeepers. The Paradox of Russian Peacekeeping, New York: United Nations University Press, 2003, S. 63.

8.Uwe Halbach, Der Countdown to war in historischer Perspektive. Konfrontation zwischen Russland und Georgien2004-2008«, in: Russland-Analysen, 192 (20.11.2009), S. 13-16

9.Nikolaus von Twickel, »Steinmeier Promotes Plan for Abkhazia«, in: The Moscow Times, 21.7.2008.

10. Ernst Piehl, Organisierte Zivilgesellschaft in Georgien, Armenien und Aserbaidschan im Kontext der Europäischen Nachbarschaftspolitik. Studie für den Europäischen Wirtschafts- und Sozialaus-schuss, Brüssel 2008, Kapitel 2.4.

11.http://gov.ge/s/10d9a

12.https://eeas.europa.eu/headquarters/headquarters-homepage/92853/2021association-implementation-report-georgia_en 


\title{
СОЦІАЛЬНА ІНЖЕНЕРІЯ
}

\author{
Свгенія Тихомирова, \\ доктор політичних, професор, \\ Волинський національний університет \\ імені Лесі Українки
}

Соціальна інженерія є спосіб організації впливу на людську діяльність, спрямований на іï перетворення за допомогою соціальних технологій. Термін «соціальна інженерія» (англ. social engineering) вперше зустрічається в роботі Р. Паунда «Введення в філософію права» в 1922 р. За іншими відомостями, сучасний зміст терміна запроповано на межі XIX-XX ст. у публікаціях 3 економіки праці британським подружжя С. і Б.Вебб [1, 39].

Більш розгорнуте обгрунтування соціоінженерной діяльності дав англійський філософ К. Поппер. Свої погляди він сформулював в 30-40-ті роки в роботах «Злидні історицизму» та «Відкрите суспільство і його вороги». К. Поппер проводив чітку грань між «утопічною соиіальною інженерією» $\mathrm{i}$ «поетапною сочіальною інженерією». Він виступав за раціональні суспільні перетворення «поетапними», «м’якими», ненасильницькими методами впливу на об’єктивну реальність з метою іiї вдосконалення [2].

Термін «інженерія» передбачає жорсткі, однозначні технології перетворювальних впливів. Фахівці вважають, що у техніці йдеться про розроблені i затверджені як документ технології (обробку металу, збірки технічного вузла і т.п.), порушення яких є неприпустимим. У словосполученні «соціальна інженерія», перше слово - «соціальна» говорить про те, що дія спрямована на людину, в ім'я людини, іiі благо, тому ні про які жорсткі методи впливу не може бути й мови. Це швидше за все різноманітний комплекс заходів, який може бути використаний $з$ урахуванням індивідуальних особливостей конкретної соціальної системи. Соціоінженерію характеризує нежорстка регламентація i алгоритмізація соціальних технологій, тісний зв’язок 3 неформальною по своїй суті поведінкою людей, орієнтація на неоднозначні вимоги до технологічного процесу, що допускає можливість творчої активності суб'єкта управління [3].

Соціоінженерная діяльність є логічно пов'язаним ланцюжком послідовних процедур:

> діагностика стану об'єктивної реальності;

$>$ соціальне прогнозування;

> моделювання соціальної конструкції і здійснення експерименту;

розробка соціального проекту нового стану соціальної реальності;

соціальне планування відповідно до проекту;

реалізація проекту за допомогою алгоритмізованих та інноваційних соціальних технологій; соціологія управління [3].

Дослідники виокремлюють соціальну інженерію як особливий напрямок практичної діяльності. Сенс цього виділення в тому, щоб підкреслити 
відмінності практичних функцій, які виконуються різними фахівцями в сфері управління, від діяльності фахівців у сфері фундаментальної науки, що виконують креативно-пізнавальну, когнітивну функцію. У той же час всі підходи в рамках соціальної інженерії спираються на різні теоретичні моделі соціальних систем (в першу чергу, організацій), використовують різний інструментарій та вирішують різні практичні завдання. Соціальна інженерія орієнтована на внесення змін в стан соціальних систем, тому особлива увага приділяється тим моделям, які описують механізм і логіку організаційних змін.

Теоретичними засадами соціальної інженерії виступають предметний i проблемний підходи. Перший розглядає соціальну дійсність як об'єктивну, детерміновану реальність, що існує за своїми законами і логікою. Це і дозволяє соціальним інженерам i управлінцям-практикам звертатися до природнонауковим схем, теоретичним концепціям і емпіричним закономірностям як джерелам прогнозування поведінки об'єкта, його характеристик. Такий погляд підкреслює передбачуваність соціальних змін, наслідки будь-якої проведеної дії. Перетворення об'єкта описується схемою: «знання природи об'єкта є основою перетворювання діяльності». На жаль, в цьому випадку спонтанна активність, свобода вибору і реалізації цілей і розробка проектів змін практично випадають 3 поля зору. У будь-якому випадку, проте, попередне напрацювання знань про природу об'єкта є необхідною умовою перетворення .

Проблемний підхід, що сформувався відносно недавно - наприкінці 60-х початку 70-х p.p. XX ст., розглядає соціальні організації як гнучкі системи взаємодії, постійно і свідомо реконструйовані їі членами. Найважливішою рисою соціального об'єкта є його активність, свобода, його здатність робити «вибір», ставити «цілі», розробляти «проекти самозмінення» і забезпечувати їх реалізацію. В основі визначення мети лежить процес виявлення і вирішення проблем, що виникають у активного соціального суб'єкта в ході його діяльності. Тут заперечується сама можливість пізнання сутності об'єкта як занадто складною і відкидається уявлення про те, що минулий стан об'єкта детермінує його майбутнє. Сама управлінська діяльність розглядається як міждисциплінарна і комплексна. У центрі уваги цього підходу виявляється проблема визначення й реалізація мети, а наслідки цієї реалізації не розглядаються.

Обидва розглянутих підходу відображають одну 3 2-х сторін соціальної реальності: 1) сферу свободи, вибору, визначення мети, яка виявляється в акті соціальної дії; 2) сферу детермінізму, закономірностей і передбачуваності поведінки і діяльності. Так, проблемний підхід зосереджує увагу на можливості людини або організації вести себе як активний суб'єкт - робити вибір, вносити зміни в області своєї життєдіяльності. Предметний підхід підкреслює, що носії соціальної реальності (людина, спільність, організація) виступають не тільки суб'єктами, але і об'єктами змін. Соціальна реальність в цьому випадку може бути описана в термінах соціального порядку, взаємозалежності, стійкості. Одним 3 найважливіших факторів, що підсилюють відмінність зазначених підходів, виступає різноманітність типів соціальних об'єктів. Ця типологія може базуватися на різних умовах: відмінності в цільових функціях організацій 
(виробничі, комерційні, соціально-благодійні тощо); технологічні відмінності характеристик (наприклад, режим роботи - змінна, сезонна і т.д.); «масштаб» соціальної освіти (наприклад, держава та іiї органи, спеціалізовані організації, цільові групи, окремі працівники) [3].

Не менш важливим є і тип розв'язуваних соиіальним інженером завдань. Зрозуміло, що орієнтація на збереження цілісності системи або на зняття соціальних напружень диктує зовсім іншу логіку дій і змін, ніж орієнтація на підвищення конкурентоспроможності організації. Комплекс соціоінженерних робіт включає в себе: дослідження - проектування та програмування впровадження та реалізації управлінських рімень. В ідеалі соціальна інженерія - це синтез раціонально-технократичних і гуманістичних ідей. Об'єктом соиіальної інженерії виступає соціально-управлінська практика, інакше кажучи, це інструмент управлінського впливу на різні інститути, організації та установи з метою їх створення, перетворення і зміни. Цьому сприяють методи соціальної інженерії - сукупність способів і засобів організації суб'єктів управління, спрямованих на підтримку стабільності і перетворення соціальних об'єктів, в тому числі на вироблення управлінських рішень і регулювання конфліктних ситуацій [3].

Одним з найбільш яскравих прикладів успішної реалізації теорії і практики соціальної інженерії є зв'язки з громадськістю, що представляють собою систему методів (технік), способів і прийомів, застосовуваних у певній послідовності для впливу на громадську думку. Адже суспільні зв'язки прагнуть конструювати ту реальність, в якій діє фірма. При цьому сама організація, відчуваючи вплив зовнішнього середовища, проходить низку перетворень і змін. Для фахівців в області соціальних комунікацій оволодіння основними методами i інструментарієм соціальної інженерії $\epsilon$ головною умовою їх успішної професійної діяльності [3].

Сьогодні соціальна інженерія стала невід'ємною частиною кібершахраїв. Мова йде про спеціальну методику маніпуляції, яка допомагає змусити людину віддати зловмисникам необхідні дані, використовуючи людські слабкості - тобто емоції та природну поведінку жертви. Існує чимало методів використання соціальної інженерії. В основі - маніпуляція людськими страхами, зацікавленістю або довірою. Жертвою соціальної інженерії можна стати як під час особистого спілкування, так і по телефону або через цифрові гаджети. Науковці вважають, що «кіберзлочинці знайшли нові способи експлуатації людського фактору - інстинктів цікавості й довіри, - які призводять до того, що люди $з$ добрими намірами потрапляють у руки зловмисників. Це може статися у формі замаскованої URL-адреси або, здавалося б, нешкідливого додатку в електронному листі. Але все, що потрібно, - це один клік, і негайно почнеться поширення шкідливої програми» [4].

Термін «соціальна інженерія» використовується для опису низько технологічних підходів, розроблених шахраями для того, щоб змусити потенційну жертву повідомити особисті дані або взяти участь у діях, які можуть зробити ії комп'ютер вразливим до атак. Це може відбуватися як через Інтернет, так і під час особистого контакту. В основу онлайнових схем соиіальної інженерії 
покладено те, що з вами в Інтернеті знайомляться на перший погляд привітні та привабливі люди (найчастіше шахраї представляються як вродлива молода дівчина, а іноді - як працівники служби підтримки клієнтів Skype). Після цього вони просять вас внести їх до списку ваших контактів. Якщо ви погодилися, вони отримують можливість відправляти вам повідомлення. У реальному світі ці люди - шахраї, а часто це навіть не реальні люди, а просто програми («боти») 3 обмеженим набором фраз у своєму скрипті, які шукають потенційних жертв для спаму чи обману [5].

Онлайнові методи охоплюють надсилання: миттєвих повідомлень, за допомогою яких вас намагаються змусити зайти на веб-сайти або завантажити файли, що містять віруси та шпигунські програми та ставлять під загрозу вашу безпеку й цілісність ваших даних; небажаних миттєвих повідомлень про продаж послуг або продуктів (спаму); миттєвих повідомлень, файлів і посилань, що містять неприпустимий або образливий вміст, який порушує умови використання Skype. Особистісні методи охоплюють: «підглядання через плече» в загальнодоступних місцях (шахрай заглядає вам через плече, коли ви вводите особисті дані). Доступ до комп’ютера, яким ви користувалися раніше, після чого не завершили сеанс роботи належним чином. Наступний користувач може видати себе за вас, і якщо ваші особисті дані все ще збережено на комп’ютері, він може отримати до них доступ [5].

\section{Список використаних джерел:}

1. Міжсекторальні взаємодії як основа публічного управління : навч. посіб. / авт. кол. : С. О. Телешун, С. В. Ситник, І. В. Рейтерович та ін. ; за заг. ред. С. О. Телешуна, д-ра політ. наук, проф. - Київ : НАДУ, 2018. - 224 с

2. Афанасьєва, М. В. Виборча інженерія в Україні. - Одеса : Юрид. л-ра, 2014. $384 \mathrm{c}$.

3. Связи с общественностью как социальная инженерия / Под ред. В.А. Ачкасовой, Л.В. Володиной. - СПб.: Речь, 2005. - 336 с.

4. Соціальна інженерія: як шахраї використовують людську психологію в Інтернеті [Електронний ресурс] - Режим доступу : https://www.radiosvoboda.org/a/socialna-inzhenerija-shaxrajstvo/29460139.htm

5. Що таке "соціальна інженерія"? [Електронний ресурс] - Режим доступу : https://support.skype.com/uk/faq/FA10921/shcho-take-sotsial-na-inzheneriya 


\title{
SOME TOPICAL ISSUES OF PSYCHOLOGICAL SCIENCE METHODOLOGY
}

\author{
Lavrinenko Vitalii \\ Candidate of Science in Psychology $(\mathrm{PhD})$, \\ senior lecturer of the Psychology Department, \\ Poltava V. G. Korolenko National Pedagogical University
}

Nowadays, psychological science, although not in a state of open methodological crisis as in the early twentieth century, but is characterized by a number of unresolved issues in the field of psychological research and cognition methodology. The existing methodological principles, formulated within different scientific schools, of course, make it possible to understand the content of the mental, to reveal the patterns of personality formation and its activities or communication, but reflect scientific, philosophical and methodological positions that are somewhat opposite. The modern psychological science methodology is diverse, such that it involves multiparadigm in the interpretation of psychic content. At the same time, today's current demands from production, education, upbringing, marketing and other areas of practice to psychological science, if they do not require it to have a single synthesized methodology, then actualize the need to harmonize the methodological positions of different schools. Therefore, this highlights the need to consider the prospects for the modern psychological science methodology development.

In fact, the situation regarding the methodology that has developed in the current psychological science reflects the formulated L.S. Vygotsky problems of this field of science in the early twentieth century, reflecting its being in a state of methodological crisis. As noted by T.V. Kornilova, S.D. Smirnov [1], in modern methodological works, the state of psychological science is assessed as pre-paradigmatic (the only paradigm has not yet been developed), and as multi-paradigmatic. The last variant presupposes a fundamental multiplicity of psychological concepts - pluralism of scientific ideas - due to the multilevel mental and irreducibility of all psychological realities to the description within a single explanatory principle. But the concept of crisis continues to be used, because behind it is dissatisfaction with the lack of a single general psychological theory. This is both pre-paradigmatic and multi-paradigmatic nature of psychological science, in fact, creates a methodological pluralism, a plurality of explanations of the mental content.

L.S. Vygotsky, describing options for the psychological science crisis exit, identified the following psychology prospects and problems.

First, it is a problem of inconsistency between the direct «given» of psychological knowledge to personality and the indirect nature of scientific knowledge, "burdened" by constructs and concepts. Criticizing the phenomenological method, L.S. Vygotsky primarily opposed the illusion of the direct «given» of psychological knowledge and the irrational way of its acceptance. 
Secondly, it is the dependence of objective knowledge on the personality inclusion in the process of experience data obtaining, or the construction of psychological reality in the course of its study. One of the variants of this topic is the reflection of those meta-approaches (as the theoretical psychology prerogatives) and new paradigms in which psychological theory seeks an empirical basis and which are overcome by formulating new tasks of psychological research.

Third, it is the idea that sounded in the late twentieth century -to unite if not theories, then the mental efforts of psychologists, standing on different theoretical platforms. Dialogue of existing approaches in order to reach the desired "inseparable unity" - a way to recreate the lost in the Soviet period, the mental space in domestic psychology. If we take into account that with the change of paradigms the criteria of what is considered scientific and what is unscientific change, the question arises how to compare theories written within different paradigms. This means that paradigms and theories differ in the way the subject is distinguished, and by research methods (subject-sensory) activities of the psychologist.

Fourth, it is no coincidence that today the question of the communicative function of the methodology of psychology is raised. As T.V. Kornilova, S.D. Smirnov says [1], the following amendments are important here:

1) it should not be about communication methodologies, but about communication between members of the scientific community. And they act not only as carriers of a certain "professional" picture of the world, but also as people who reflect, and therefore are capable of intellectual coverage and those "psychologies" whose positions they do not share;

2) the communicative function can be performed by those theories, the development of which promotes the psychological knowledge integration. It is in this vein that it is important for foreign researchers to turn to the cultural-historical concept.

Thus, the overcoming the crisis in psychology problem historical and psychological context can be reformulated into the psychology methodology context, really absorbs the achievements of previous periods, but does not limit its horizons to the achievements of one methodological direction, and provides a world of open theories. This openness is included in the characteristics of any thorough theoretical and empirical research, because a good scientific work always involves a comparison of the data obtained by a psychologist from the standpoint of other theories.

Assessing the state of modern psychological science, we can say that formulated more than 100 years ago by Vygotsky methodological problems to this day remain unresolved despite the significant accumulation of empirical data, developed methodology within different scientific and psychological approaches, and so on. In particular, the problem of psychological scientific cognition objectivity or subjectivity, its burden of categories and constructs, scientist's change of reality in the cognition process (according to given theoretical constructs), lack of dialogicity in methodologies of different scientific psychological schools, remains unsolved.

Particular importance in the light of current psychology methodological problems are issues of dialogicity and the research results large number presence in psychology in the absence of common methodological positions of its understanding. Regarding the content of these problems, we can note that the dialogicity principle is becoming 
increasingly important in epistemology, the understanding psychological phenomena methodology. In particular, in this context we are talking about the need for different scientific schools dialogicity, and the need for communication between different sciences in understanding the content of the psychic at a higher - synergistic - level, and the dialogicity between different aspects of the psyche in ontogenesis, activities, social phenomena. It is clear that the dialogicity phenomenon acquires different meanings and interpretations in these perspectives, but the overly important role of dialogicity in the understanding of the mental is obvious, because, as noted by Z.S. Karpenko [2], only under the condition of dialogic interaction, the presence of a constant double reflection, human consciousness can become integral and formed. However, the question of such dialogicity implementation remains open - as to how to implement the dialogicity of scientific approaches, dialogicity in the content of the psychic, and so on at a qualitatively high level. Therefore, the implementation of the dialogicity principle is an important methodological perspective.

At the same time, the author made an attempt to analyze indicators of dialogic consciousness of youth, which are part of informal associations, which showed a multifaceted system of connections and correlations between the structuring of social space in subcultures, interaction within subculture ideological content activity and young persons consciousness content and structural characteristics. In this case, dialogicity acted as an essential characteristic of value-meaning consciousness, which allowed adolescents to integrate the ideals of the subculture through its "semantic patterns" by conducting timeless and non-spatial dialogue between one adolescent and subculture ideas in general, not just its followers (V.A. Lavrinenko [3]).

As D.M. Borsboom, J. Dalege notice [4] an modern psychological science urgent problem is the development of interpretive schemes for analyzing the results of empirical research. In particular, they consider a complex system of connections between the theory, the phenomenon under study and empirical data, which is realized through the mechanisms of explanation and generalization. At the same time, analyzing a large number of relevant studies, we can note the general trend today to describe a large number of narrowly specialized psychological research studies without providing them with qualitative analysis and interpretation. Using the explanation of D.M. Borsboom, J. Dalege [4] can be noted that scientific data and theory and phenomenon in this area are disparate, as the description of research data increasingly takes the form of presenting large amounts of statistics, representations in the form of averages, variances, without providing such numerical patterns of qualitative interpretation. However, the provision of quantitative indicators to describe the severity of various psychological phenomena is not the purpose of psychological research, which should establish certain patterns or mechanisms, and not just state the presence or absence of certain characteristics, relationships in a particular group.

Therefore, the current psychological science problems can be defined as the need to solve classical methodological problems of knowledge subjectivity, change reality in the process of scientific knowledge, and the implementation of dialogicity in the psychology methodology, solving the empirical data and their interpretation in terms of scientific psychological theories and concepts consistency problem. 


\section{References}

1. Корнилова Т. В., Смирнов С.Д. Методологические основы психологии : учебник для академического бакалавриата. М. : Издательство Юрайт, 2016. 490 с.

2. Карпенко 3. Аксіологічна психологія особистості : монографія. Івано-Франківськ : ДВНЗ «Прикарпатський національний університет імені Василя Стефаника», 2018. 720 с.

3. Лавріненко В.А. Структурні та змістовні характеристики смислової сфери підлітків із неформальних об'єднань/ Психологія і особистість. 2020. № 1. C. 71-93.

4. Borsboom, D., van der Maas, H., Dalege, J., Kievit, R., \& Haig, B. (2020, February 29). Theory Construction Methodology: A practical framework for theory formation in psychology. https://doi.org/10.31234/osf.io/w5tp8 


\section{ПОТЕНЦІЙНІ РИЗИКИ РАННЬОЇ ВАГІТНОСТІ}

\section{Гречин Наталія Тарасівна}

студентка

Західноукраїнський національний університет

У сучасному суспільстві часто ми стикаємось 3 такими проблемами як: наркоманія, паління, алкогольна залежність, аборт. Такі явища $є$ дуже поширеними серед підлітків, оскільки оточення, цікавість, прагнення спробувати все в житті спонукають частину інфантильних неповнолітніх до девіантних дій, котрі потім спричинюють моральне опустошення, психічне напруження, тривожність, почуття провини тощо [1].

На даному етапі підліткова вагітність вже не вважається чимось винятковим, адже таких випадків $є$ безліч, проте суспільство забуло про фактори ризику цієї проблеми: психічна нестабільність як матері так і батька, не готовність брати відповідальність за життя дитини, зрештою не розуміння всієї серйозності ситуації, яка склалась, відкидання іiі [2, с. 288].

Переривання вагітності у 2018 році, за даними Міністерство охорони здоров'я України, зробило близько 400 неповнолітніх. Проте це лише офіційні дані. $\in$ ситуації коли підліток сам робить усе для аборту, вдається до народних методів і шкодить здоров'ю не лише дитини, а й своєму. Також часто трапляються суїцидальні наслідки, оскільки страх реакції авторитарних батьків, висміювання з боку однолітків, штовхають дівчинку-підлітка до крайньої форми «втечі» від небажаної ситуації [3].

Таким чином проблема ранньої вагітності є однією з найважливіших проблем суспільства, адже через малу поінформованість та не достатнє сексуальне виховання підлітки, не розуміючи цього самі, скоюють злочин і руйнують життя собі та завдають шкоди ще не народженій дитині. Можна виокремити такі групи основних ризиків ранньої вагітності:

1) біологічний;

2) соціальний;

3) психологічний.

Розглядаючи детальніше дані ризики варто виокремити такі загрози, які виникають на біологічному рівні при ранній вагітності: 1) не сформований організм часто неспроможний витримати велике фізичне навантаження; 2) максимальні ризики викидня; 3) ускладнення протягом вагітності, а саме: прееклампсія, передчасні пологи, внутрішньоутробна затримка росту плода, через які дитина не завжди народжується здоровою [4, с. 85].

На соціальному рівні виникають також не менші труднощі адже: 1) суспільство не завжди сприймає молоду матір, осуджує іiі; 2) відсутність підтримки близьких людей, зокрема батьків; 3) відсутність професії, а відтак належного економічного забезпечення; 4) відсутність соціально-побутових умов (житла і матеріального забезпечення себе і дитини) [5]. 
Зрештою не менш важливим $є$ психологічний аспект, адже: 1) не сформована та не стійка психіка майбутньої матері не дає можливості повністю охопити всю серйозність та відповідальність вагітності; 2) тиск з боку суспільства часто призводить до депресивного стану, під час якого людина вбиває і себе і дитину; 3) низька психологічна готовність стати матір'ю, несформованість емоційновольової сфери, недостатній життєвий досвід є своєрідними психологічними бар'єрами на шляху ефективного материнства [6].

Зачасту аборт $є$ рішенням, яке приймається молодою матір'ю зі своїх суб' єктивних міркувань, проте існують випадки, коли ії до цього цілеспрямовано спонукають оточуючі принизливими словами чи діями.

Отже, можна зробити висновок, що проблема ранньої вагітності є дійсно актуальною в сучасному світі, адже $є$ дуже мало заходів для того аби забезпечити здорову психологічну атмосферу матері, соціальні умови та становище не завжди можуть відповідати прожитковому мінімуму, а для людини, яка ще не досягла повноліття і $є$ психічно не стабільною ці мінімуми мають бути більш досконалими. Так, у Нью-Йорку існує превентивна програма, яка була заснована психологом Майклом Каррером. Дана програма допомагає підлітку побачити різницю між успішним дорослим життям та передчасною вагітністю, а саме включає в себе шість напрямків:

1) заняття спортом та мистецтвом;

2) робота за скороченим графіком;

3) консультування з освіти;

4) медичні та стоматологічні послуги;

5) секс-освіта;

6) ведення власних фінансів.

Дана програма налічує близько 4 тисячі учасників та охоплює 12 штатів, вона $\epsilon$ досі успішною та отримує безліч позитивних відгуків. Дівчата наголошують що завдяки програмі підліток постійно є зайнятим, він знаходить собі роботу, відкриває нові хобі та власні таланти, надихається та розвивається, а також детально вивчає сексуальну культуру та поведінку і розуміє, що на кожному етапі життя людина має своє призначення і не потрібно поспішати дорослішати [8].

Фонд Населення ООН повідомляє про те, що кожного року близько 16 мільйонів неповнолітніх дівчат народжують, три мільйони йдуть робити нелегальний аборт, що вносить неабиякі корективи у їхнє майбуття [8].

Аборт, який часто трапляється в ситуаціях ранньої вагітності не $є$ тим, що може допомогти, адже після скоєного людина переживає емоційне виснаження, морально пригнічує себе сама за скоєний вчинок, що відображається на майбутньому і несе за собою вже незворотні наслідки. Для того аби запобігати не бажаній вагітності потрібно аби сексуальна культура підлітків була дещо на іншому рівні, ніж вона є зараз, а для цього потрібно щоб батьки, освітяни, медики, відповідні молодіжні організації та адміністративні управління здійснювали просвітницько-пропагандистську діяльність щодо того як важливо бути психологічно готовим до наслідків раннього статевого життя, до чого це може призвести і які плюси та мінуси такого становища. Варто перейняти досвід 
США та поширювати іiі в усьому світі, адже описана програма дійсно дає неабиякі позитивні результати.

\section{Список літератури}

1. Абросимова 3. Б., Адамчук Д. В., Баранова О. В. Сексуальна поведінка в підлітковому середовищі. Початкова школа плюс до і після. 2004. № 3. С. 25.

2. Населення України. Народжуваність в Україні у контексті суспільнотрансформаційних процесів. Київ : АДЕФ-Україна 2008. 288 с.

3. Стець А. В Україні в 2018 році майже 400 неповнолітніх зробили аборти. Голос Америки: Суспільство, 30 березня 2019. URL: https://zaxid.net/v_ukrayini_v_2018_rotsi_mayzhe_400_nepovnolitnih_zrobili_aborti _n1478567 (дата звернення: 25.02.2021).

4. Гурко Т. А. Опыты сексуальных отношений, материнства и супружества несовершеннолетних женщин. СОЦИС. 2002. № 11. С. 83-91.

5. Гірняк А.Н. Різновиди міжсуб'єктної взаємодії та їх психологічний аналіз. Психологія і суспільство. 2017. № 4. С. 82-86.

6. Гірняк А.Н., Глова І.М. Передумови формування гармонійної міжособистісної взаємодії в молодій сім’і. Україна в умовах реформування правової системи: сучасні реалії та міжнародний досвід: матеріали IV міжнар. наук.-практ. конф., м. Тернопіль, ТНЕУ, 5-6 квітня 2019 р. Тернопіль : Економічна думка. 2019. Т. 2. С. 133-136.

7. Гірняк А.Н. Карп'як Т.М. Соціально-психологічні детермінанти делінквентності підлітків. Актуальні задачі сучасних технологій : зб. тез доп. міжнар. наук.-техн. конф. молодих учених та студентів. м. Тернопіль, 17-18 листоп. 2016. Тернопіль: ТНТУ, 2016. Т. 2. С. 318-319.

8. Рання вагітність. Голос Америки: Суспільство, 12 липня 2013. URL: https://ukrainian.voanews.com/a/1700042.html (дата звернення: 10.03.2021). 


\section{АНАЛІЗ СОЦІАЛЬНО-ПСИХОЛОГІЧНОЇ ТА СОЦІОЛОГІЧНОЇ ТЕОРІЙ ПСИХІЧНОЇ ДЕПРИВАЦІЇ}

\section{Терлецька Юліана Миронівна,}

кандидат психологічних наук, доцент, доцент кафедри педагогіки та інноваційної освіти Національний університет «Львівська політехніка»

Розвиток соціально-психологічної теорії психічної депривації відбувся завдяки працям Л. Виготського [4], М. Лісіної [8], В. Мухіної [10], Я. Гошовського [6], $\quad$ О. Алексеєнкової [1], М. Кондратьєва [7], I. Брецко [3] та ін.

Соціально-психологічна теорія психічної депривації пояснює затримання, сповільнення розвитку дитини, а також відхилення в поведінці дорослого через їхню нездатність налагодити необхідні соціально-психологічні зв'язки, які знаходяться в межах усієї соціально-психологічної системи, або внаслідок їх розриву. Відповідно до даного розуміння, соціально-психологічний розвиток дитини відбувається не лише за допомогою навчання окремим видам соціальної діяльності й не обмежується також лише зв'язком “дитина-мати” і “дитинасім'я”. Насправді дитина є складовою частиною всієї соціальної системи і завжди поступово засвоює формулу всієї іiі організованої соціально-психологічної структури з усіма іiі численними зв'язками і ролями (з поведінкою, котра відповідає певним соціальним позиціям і статусам). Разом з цим, вона вчиться виконувати не лише ті ролі, які сама поступово переймає і здійснює, а й ті, які стосуються інших осіб, наприклад матері й батька. Знання цих ролей дитина засвоює шляхом безпосередньої участі в соціальних взаємодіях - спочатку 3 матір'ю і батьком, пізніше у більш широких рамках сім’і, малій дитячій групі, шкільному класі, школі, великій соціальній групі, соціумі.

Виходячи з культурно-історичної концепції Л. Виготського, інтеріоризація, як основний механізм розвитку дитини, можливий лише за умови постійного контакту 3 дорослими. Тому обмеження «системи стосунків між дитиною певного віку та соціальною дійсністю» $є$ головною причиною виникнення затримки розвитку дитини [4]. За таких обставин соціальна “ситуація розвитку" для дитини перетворюється в “ситуацію неможливості”, що сприяє виникненню у неї загального напруження і важких афективних станів.

Головними умовами особистісного розвитку дитини М. Лісіна [8] також вважає задоволення потреб у спілкуванні, позитивні стосунки з батьками, їх виважене ставлення та ініціативні звернення до дитини як до особистості. I коли така взаємодія відбувається з дня народженням дитини, то вона відкриває власну суб'єктивність і своїх близьких людей. Відсутність таких значущих для дитини стосунків знижує ії здатність до інтеріоризації, розвитку, одним словом, гальмує розвиток особистості.

У концепції розвитку особистості, розробленій В. Мухіною, головними ii механізмами визначаються ідентифікація, яка “відповідає" за соціалізацію, 
тобто набуття індивідом своєї людської сутності, та відокремлення, котре дає можливість вибрати індивідуальний шлях формування власної індивідуальності [10]. Тому депривація головних потреб дитини, котра розвивається в умовах сирітського закладу, викликає у неї стан фрустрації, спричиняє викривлення розвитку їі особистості та структурних компонентів самосвідомості.

Якщо в соціально-психологічній структурі дитини відсутній будь-який суттєвий елемент, який визначає чітку соціальну роль (наприклад, якщо в родині відсутні батько, мати, брати і сестри, або якщо відсутнє спілкування 3 однолітками), то з цього слідує, що індивід позбавлений досвіду щодо деяких компонентів культури, які дітьми засвоюються зазвичай у взаємодії з іншими людьми. Психічна депривація може в даному розумінні розцінюватися, насамперед, як дефект у вивчені соціальних ролей, обумовлений відсутністю певного необхідного досвіду в сфері соціально-психологічної взаємодії в дитинстві.

Наслідки ж подібної депривації видно в неповній і недостатній соціалізації дитини, яка погано підготовлена для належного виконання цілої низки соціально-психологічних ролей, які будуть від неї очікуватися в суспільному житті, в тому числі у шлюбі, як батько або мати, в дружбі, у співробітництві 3 іншими людьми і под. Ї̈ здатність передбачати позиції інших людей буде обмеженою, так само як вміння робити відмінності між соціальними ситуаціями, котрі висувають різні вимоги.

В дорослого психічна депривація також спричиняє відхилення у спілкуванні, соціальній взаємодії, виконанні соціальних ролей, поведінці та ін.

Отже, соціально-психологічна теорія психічної депривації розкриває iї як явище, яке виникає в людини внаслідок незасвоєння нею змісту та значення соціально-психологічних зв'язків і соціальних ролей, які мають місце в суспільстві, в різних соціальних групах. Однак, у даній теорії не розкривається, яким чином незасвоєні соціально-психологічні зв'язки і соціальні ролі відображаються у психіці людини? Які зміни спричиняють в ії різних сферах? Як впливають на функціонування всієї психіки, а також на поведінку людини.

У соціології є теорія депривації індивіда i/чи соціальної групи, яка полягає в суб'єктивному сприйнятті й болісному переживанні матеріальної нерівності чи неможливості задовольнити свої базові потреби (виділено нами - Ю.Т.), що, безсумнівно, вказує на її розгляд як психічної депривації. У цій теорії вирізняють абсолютну та відносну депривації. Абсолютна депривація являє собою неможливість індивіда або соціальної групи задовольнити свої базові потреби через відсутність доступу до основних матеріальних благ і соціальних ресурсів. Насамперед, мається на увазі доступ до продуктів харчування, житла, освіти, медицини тощо. Відносна депривація являє собою суб'єктивне сприйняття й болісне переживання не співпадіння "ціннісних очікувань" (блага та умов життя, які, як думають люди, вони заслуговують по справедливості) i "ціннісних можливостей” (блага і умови життя, які, також на думку людей, вони можуть отримати в реальності).

Поняття “депривація" у відносному значенні в соціологію вперше ввів С. Стауффер у праці “The American Soldier” (“Американський солдат”) у 1949 
році, що базувалася на результатах емпіричного соціологічного дослідження, проведеного під час Другої Світової війни Військовим департаментом США. За С. Стауффером, депривація є одним із чинників розвитку соціальної групи $\mathrm{i}$ суспільних організацій, який суб'єктивно проявляється у вигляді невдоволеності, що переживає група відносно свого дійсного стану, а об'єктивно - як прагнення цієї групи досягнути рівня іншої, більш розвинутої чи благополучної в соціальному відношенні групи [11]. У відносному значенні поняття “депривація" використане також у роботі Р. Мертона "Social Theory and Social Structure” (“Соціальна теорія і соціальна структура”, Нью-Йорк, 1949) [9]. Подібною до відносної депривації $є$ концепція статусної неузгодженості (неконгруентності) Г. Ленські, яка розкриває статусну неузгодженість, що проявляється в розходженні у становищі індивіда (або групи) в ієрархічній організованій структурі, відображеній у термінах різних соціальних координат: рівня доходу, освіти, віку, місця в структурі влади тощо. Приклад такої неузгодженості - низький рівень прибутків за високого рівня освіти. Згідно з Г. Ленські, статусна неузгодженість має об'єктивний (як явище у суспільстві) i суб'єктивний (як усвідомлення людиною цієї неузгодженості) характер. При цьому депривація може бути визначена як розходження між очікуваннями осіб (соціальної групи) і можливостями, запропонованими суспільством для їх реалізації [12]. Для вимірювання відносної депривації використовують формулу T. Гарра: $\mathrm{RD}=\left(\mathrm{V}_{\mathrm{e}}-\mathrm{V}_{\mathrm{c}}\right) / \mathrm{V}_{\mathrm{e}}$, де $\mathrm{RD}$ - рівень депривації, $\mathrm{V}_{\mathrm{e}}$ - очікувана позиція, $\mathrm{V}_{\mathrm{c}}$ - доступна чи досягнута позиція. $\mathrm{RD}=1$ при $\mathrm{V}_{\mathrm{c}}=0$ (суспільство не надає жодних можливостей для реалізації очікувань), $\mathrm{RD}=0$ при $\mathrm{V}_{\mathrm{c}}=\mathrm{V}_{\mathrm{e}}$ (суспільство надає всі можливості для реалізації очікувань), $\mathrm{RD}<0$ при $\mathrm{V}_{\mathrm{c}}>\mathrm{V}_{\mathrm{e}}$ (досягнуто більше, ніж очікувалося) [5].

Таким чином, соціологічна теорія депривації індивіда i/чи соціальної групи розкриває ï як явище, котре полягає в суб'єктивному сприйнятті й болісному переживанні матеріальної нерівності чи неможливості задовольнити свої базові потреби. Вона поділяється на абсолютну та відносну. Однак, у соціологічній теорії психічна депривація не розкрити як явище психіки, тобто на психічному рівні.

\section{Список літератури:}

1. Алексеенкова Е.Г. Личность в условиях психической депривации: учебное пособие. СПб. : Питер, 2009. 96 с.

2. Берн Э. Игры в которые играют люди. Психология человеческих взаимоотношений. Люди которые играют в игры. Психология человеческой судьбы. Минск: ПРАМЕБ, 1992. 383 с.

3. Брецко I.I. Психоемоційне вигорання підлітків в умовах сімейної депривації : монографія. Мукачево : МДУ, 2015. 293 с.

4. Выготский Л.С. Избранные психологические произведения. Москва : Изд. АПН РСФРС, 1956. $346 \mathrm{c.}$

5. Гарр Т. Почему люди бунтуют? Санкт-Петербург : Питер, 2005. 461 с. 
6. Гошовський Я.О. Становлення образу Я в підлітків школи-інтернату в умовах депривації батьківського впливу: дис. ... канд. психол. наук: 19.00.07 педагогічна психологія, вікова психологія. АПН України, Інститут психології імені Г.С. Костюка. К., 1995. 177 с.

7. Кондратьев М.Ю. Социальная психология закрытых образовательных учреждений. Санкт-Петербург : Питер, 2005. 304 с.

8. Лисина М.И. Проблемы онтогенеза общения : монография. Москва: Педагогика, 1986. 144 с.

9. Мертон Р.К. Социальная теория и социальная структура / Пер. с англ. Е.Н. Егоровой, и др.; науч. ред. 3.В. Коганова. Москва : АСТ, Хранитель, 2006. 873 с.

10. Мухина В.С. Лишенные родительского попечительства. Москва : Просвещение, 1991. 223 с.

11. Стауффер С. Методы исследования. «Американский солдат» (1949). URL: https://socna5.at.ua/publ/1-1-0-14.

12. Lenski, Gerhard E. Power and Privilege: A Theory of Social Stratification. University of North Carolina Press, 1984. 


\title{
МОРАЛЬНА СВІДОМІСТЬ ТА СЕКСУАЛЬНА ПОВЕДІНКА МОЛОДІ
}

\author{
Федик Оксана Василівна \\ кандидат психологічних наук, доцент \\ кафедри загальної та клінічної психології \\ Прикарпатський національний \\ університет імені Василя Стефаника
}

Сучасне українське суспільство переживає не лише глибоку соціальнуекономічну і політичну кризу, а й кризу екзистенційну, морально-духовну, що характеризується втратою людьми життєвих орієнтирів та сенсу життя, руйнуванням моральних цінностей і світогляду.

Моральна сфера - складний конструкт людської психіки і поведінки, в основі якого лежить унікальне утворення — моральна свідомість. У працях Б.Братуся, Л.Іванченко, О.Дробницького, Л.Божович та інших широко висвітлювались питання природи моралі, моральної культури, еволюції моральних категорій. Складниками моральної культури, на думку дослідників, $є$ моральна свідомість і самосвідомість, які грунтуються на загальнолюдських нормах і цінностях, ідеалах і моральних принципах.

Як зазначає Р.Павелків, моральний розвиток особистості являє собою здатність людини розуміти, інтеріоризувати суспільні вимоги, засвоювати морально-етичні приписи та вибудовувати свою поведінку відповідно до них. Учений розглядає моральну свідомість як особливий конструкт психіки, що забезпечує розуміння і прийняття моральних законів та організацію людиною відповідно до них власної поведінки [1].

М.Боришевський зауважує, що моральність не можна обмежувати лише певними внутрішніми аспектами чи моментом поведінки. Вона народжується, визріває, формується та функціонує у моральній діяльності, моральній поведінці. За його розумінням, моральність є головною складовою духовності, що дає можливість особистості осмислити сенс власного життя, збагнути мету, задля якої вона живе, усвідомити свою неповторність, відповідальність за все, що робить [2].

Формувати моральну поведінку особистості як систему моральних вчинків означає формувати особистість, що володіє морально-психологічними якостями, моральною свідомістю. Формування особистості - це процес ii соціалізації, тобто засвоєння індивідом соціального досвіду в результаті цілеспрямованих виховних і стихійних впливів Ключовим фактором, який визначає рівень моральної свідомості $є$ виховання, освіта, навколишнє середовище. Слід пам'ятати, свідомість особистості неможливо розглядати окремо від суспільної свідомості, зміна якої зрештою призводить до зміни особистої свідомості окремої людини. Формуючи моральну свідомість особистості, неможливо не враховувати ті зміни, які відбулися в суспільстві [3]. 
Сьогодні молодь стоїть перед дилемою вибору орієнтирів на полюсах «добра та зла», моралі й аморальності. Саме тому процес входження молодих людей у доросле, самостійне життя, здатних не тільки контролювати себе, навколишній світ, а й творити нові моральні орієнтири та цінності, повинні бути предметом постійної уваги широкого загалу спеціалістів різних галузей. Свідоме ставлення до норм і правил моралі, їх адекватне розуміння веде не тільки до самостійності молоді в моральному виборі форм моральної активності, а й зумовлює становлення системи цінностей, ідентифікації з омріяним ідеалом дорослого майбутнього [4].

Специфіка соціалізації молодої людини полягає в тому, що вона переважно проходить крізь сприйняття й оцінку однолітків та людей, які ії безпосередньо оточують. Саме під впливом цього соціального оточення формуються, перш за все, погляди й переконання, iï ставлення до навколишньої дійсності. Безпосереднє соціальне оточення (мікросередовище) є ніби проміжною ланкою між молодою людиною й суспільством. Крізь мікросередовище, його особливості молодь своєрідно й специфічно опановує макросередовище [5].

У сфері сексуальної моралі відбуваються важливі зрушення. Хоч моральне регулювання й оцінка сексуальних стосунків не зникають, вони стають гнучкішими i реалістичнішими. В результаті, зменшується розрив між повсякденною, побутовою та офіційною мораллю i, отже, стає менше лицемірства. Звужується коло явищ, що морально оцінюються.

Сьогодні ми спостерігаєм переорієнтацію громадської думки щодо сексуальної поведінки молоді. Звичними і доступними стають еротичні шоу, сексуальні сцени, 3 іншого боку зберігається низький рівень сексуальної культури молоді. Послаблення зовнішнього соціального контролю над поведінкою молоді, соціальна терпимість «розкодовує» сексуальність, дає підстави говорити про моральну легалізацію невпорядкованих статевих зв'язків, свободи.

Зазначимо основні тенденції динаміки сексуальної поведінки - більш раннє сексуальне дозрівання і пробудження еротичних почуттів у підлітків; зниження віку сексуального дебюту; соціальне та моральне прийняття дошлюбної сексуальності і співжиття; послаблення “подвійного стандарту" різних норм i правил сексуальної поведінки для чоловіків i для жінок; емансипація сексуальної мотивації від матримоніальної; зростання кількості розлучень, дошлюбних і позашлюбних зачать і народжень, підвищення інтересу до еротики, підвищення сексуальної активності; звуження сфери забороненого в культурі й зростання суспільного інтересу до еротики; ріст терпимості щодо девіантних форм сексуальності; зростання розриву між поколіннями у сексуальних установках, цінностях і поведінці.

Поведінка, що підпорядкована системі власних моральних цінностей і $€$ їх реалізацією, свідчить про звільнення особистості від ситуативних впливів, про іiі здатність до свідомого керування своєю активністю, у тому числі і сексуальною. У зв'язку з цим моральні цінності набувають ролі внутрішнього механізму регуляції поведінки. Таке розуміння цінностей дає підстави розглядати їх не тільки як елементи мотиваційної структури особистості, а ще і як важливий 
елемент структури моральної свідомості, який виступає основою для здійснення людиною вибору тих чи інших сексуальних нормативів[6].

В юнацькому віці відбувається глибокий вибір моральної позиції. Моральна самосвідомість в цьому віці має свою специфіку. Юність привносить в моральну свідомість якість новоутворення, що звичайно, враховують попередній розвиток, але все ж є іншою, більш високою сходинкою. Дорослість полягає у внутрішньому зростанні особистості, іiі моральній та соціальній зрілості, що виявляється не лише усвідомленням своїх можливостей, а й щоденною працею над собою. Важливою ознакою морального змужніння $\epsilon$ вміння особистості володіти собою. Про моральну зрілість, моральну самосвідомість особистості, рівень ¥ї вихованості, свідчить і наявність базових інтегративних гуманістичних цінностей - відповідальність, гідність, свобода, самодостатність.

Отже, проблема формування моральних цінностей сучасної молоді повинна постійно перебувати в полі зору психологів, психологічної служби школи, навчального закладу, суспільства. Завдяки взаємодії механізмів наслідування, ідентифікації, інтерналізації, інтеріоризації, виховання та освіти відбуватиметься засвоєння молоддю системи цінностей, на основі яких сформується моральна свідомість.

\section{Список літератури:}

1. Павелків Р. В. Розвиток моральної свідомості та самосвідомості в молодшому шкільному віці: автореф. дис. на здобуття наук. ступеня д-ра. психолог. наук: спец.19.00.07 «Педагогічна та вікова психологія» / Р.В. Павелків .- К., 2005.40c.

2. Боришевський М. Й. Соціально-психологічна сутність та генеза духовності особистості / М. Й. Боришевський // Проблеми загальної та педагогічної психології. - К., 2009. - Т. 11. - Ч. 5. - С. 50-59.

3. Федик О.В. До проблеми сексуальної культури сучасної молоді./О.Федик //Вісник Прикарпатського університету. Філософські і психологічні науки.2014.-Вип.18.-С.157-162.

4. Мащак, С. О. До проблеми формування моральних цінностей сучасної молоді / С. О. Мащак // Психологічні перспективи / Волин. нац. ун-т ім. Лесі Українки, Ін-т соц. та політ. психології АПН України ; [редкол.: Л. Засєкіна (голов. ред.) та ін.]. - Луцьк, 2012. - Вип. 20. - С. 153-160.

5. Іванченко I.I. Виховання моральності особистості в умовах сучасних i модернізаційних змін. //Збірник наукових праць" Теоретико-методичні проблеми виховання дітей та учнівської молоді", Черкаси.-2010.-С.37-44

6. Кравець, В. Трансформація сексуальних цінностей на сучасному етапі розвитку України / Володимир Кравець // Україна-Свропа-Світ. - 2017 . Вип. 20 - С. 305-313. 


\title{
ОСОБЛИВОСТІ ВИКОРИСТАННЯ ВІРТУАЛЬНИХ ЛАБОРАТОРІЙ В НАВЧАЛЬНО-ОСВІТНЬОМУ ІНФОРМАЦІЙНОМУ ПРОСТОРІ
}

\author{
Кавин Ярослав Михайлович \\ доцент, к.т.н., начальник управління міжнародних зв'язків \\ Українська академія друкарства \\ м.Львів, Україна \\ Кавин Святослав Ярославович \\ аспірант, факультет міжнародних відносин \\ Львівський національний університет імені Івана Франка \\ м.Львів, Україна \\ ORCID: 0000-0002-6189-3848
}

Кавин Ольга Миколаївна аспірантка, кафедра фінансово-економічної безпеки,

Українська академія друкарства м.Львів, Україна

Інформатизація освіти вплинула на традиційні підходи у навчанні: крім залучення технічних новацій, використання інтернет-простору, впровадження інтерактивних технологій, особлива увага приділяється питанням використання спеціалізованих програмних засобів для проведення, відтворення та демонстрації різних систем та процесів. Відповідно з'явилися нові інтерактивні форми і підходи в освітньо-науковому процесі, зокрема: такі як «віртуальна лабораторія» і «віртуальний лабораторний практикум».

Віртуальна лабораторія (ВЛ) - це віртуальне навчально-наукове середовище, яке дозволяє моделювати поведінку об'єктів реального світу в комп'ютерному середовищі і допомагає в оволодінні новими знаннями та вміннями. Така лабораторія може виступати апаратом досліджень різних систем та процесів 3 можливістю побудови їх математичних моделей [6]. Використання ВЛ дає змогу не лише спостерігати за певним експериментом, а й безпосередньо брати в ньому участь, а це в свою чергу сприяє засвоєнню знань на більш свідомому та глибокому рівні. На основі цього ВЛ можна визначити, як програмно-апаратний комплекс, що дозволяє проводити досліди без безпосереднього контакту 3 реальною установкою або при повній ії відсутності [4], окрім того ВЛ - це віртуальне програмне середовище, в якому організована можливість поводження досліджень моделей об'єктів, їх сукупностей і похідних, заданих 3 певною часткою деталізації щодо реальних об'єктів, в рамках певної галузі знань [2]. 
Варто зазначити, що переваги ВЛ над реальними проявляються у наступному: можливість моделювання процесів, протікання яких принципово неможливо в лабораторних умовах; можливість проникнення в тонкощі процесів і спостереження відбувається в іншому масштабі часу; безпека при роботі 3 небезпечними речовинами чи приладами; можливість швидкого проведення серії дослідів з різними значеннями вхідних параметрів; можливість використання віртуальної лабораторії в дистанційному навчанні [5].

Окрім того, при реалізації та забезпеченні навчально-наукового процесу необхідно пам'ятати, що віртуальна модель відображає реальні процеси і явища в більш-менш спрощеному, схематичному вигляді, тому з'ясування питання, що насправді підкреслено в процесі, а що залишилося за кадром, може бути однією 3 форм завдання. Роботи такого виду можна виконувати цілком в комп'ютерному варіанті або зробити одним з етапів в ширшій роботі, яка включає також роботу з натуральними об'єктами та лабораторним обладнанням.

Невід'ємною складовою навчального процесу у сучасній освіті $\epsilon$ лабораторний практикум. Розвиток віртуального лабораторного практикуму відбувається в основному за двома напрямками, зокрема: так звані віртуальні симулятори і дистанційно виконувані лабораторні роботи. [1].

Віртуальні симулятори - це реально виконувані лабораторні роботи, під час яких визначені дані можуть бути занесені до пам'яті персонального комп'ютера та дистанційно опрацьовані на віртуально представленому комп'ютером засобі. Це так званий тренажер - інструмент, що імітує експерименти, демонстрації чи процеси. Однією 3 головних особливостей віртуальних симуляторів $\epsilon$ ïx інтерактивні можливості. Інтерактивне моделювання набуває все більшого значення як засіб для вивчення і розуміння складних ідей.

При використанні віртуальної лабораторної роботи створюється ілюзія роботи на реальному обладнанні. Причому «експериментальні» значення вимірюваних величин визначаються самостійно на реальних установках.

Дистанційно виконувані лабораторні роботи мають принципову відмінність від віртуальних симуляторів. Якщо при виконанні лабораторної роботи за допомогою віртуального симулятора $є$ можливість тільки навчатися, тобто отримувати навчальну інформацію як заздалегідь відомі результати, то виконувані лабораторні роботи являють собою автоматизовану лабораторну роботу з дистанційним керуванням. Тому основним завданням при організації віртуальних робіт $є$ автоматизація процесу вимірювання [3].

Віртуальні лабораторні роботи дають можливість отримувати реальні умови для виконання експериментальних завдань, порівнювати виміряні дані експерименту із сучасним фізичним експериментом, який проведено на дорогому науково-дослідному обладнанні, і таким чином засвоювати нові інформаційні технології.

Аналіз застосування віртуальних лабораторій в інформаційному середовищі навчально-наукових процесів дає змогу зробити наступні висновки: - віртуальні лабораторії як наочний засіб навчання мають багато можливостей та великі перспективи для застосування в навчально-виховному процесі; 
- віртуальні лабораторії дають змогу безпосередньо брати участь у віртуальному експерименті, змінювати параметри експерименту, таким чином підвищують рівень активації та інтелектуалізації навчального процесу.

\section{Список використаної літератури}

1. Галелюка І.Б. Віртуальні лабораторії автоматизованого проектування як інструмент міждисциплінарних досліджень: передумови створення // Інформаційні технології та комп’ютерна інженерія. - 2009. - №1(14). - С.3338.

2. Козловский Е.О. Виртуальная лаборатория в структуре системы дистанционного обучения / Е.О.Козловский, Г.М.Кравцов // Информационные технологии в образовании. - 2011. - № 10. - С. 102-109.

3. Кудін А.П. Програмне забезпечення реальних фізичних лабораторних практикумів / А.П. Кудін, А.О. Юрченко // Збірник наукових праць Кам’янецьПодільського національного університету імені Івана Огієнка. Серія педагогічна. - Кам'янець-Подільський: Кам'янець-Подільський національний університет імені Івана Огієнка. - 2015. - Вип. 21: Дидактика фізики як концептуальна основа формування компетентнісних і світоглядних якостей майбутнього фахівця фізико-технологічного профілю. - С. 248-251.

4. Мазур М.П. Особливості розробки віртуальних практичних інтерактивних засобів навчальних дисциплін для дистанційного навчання / М. П. Мазур, С. С. Петровський, М. Л. Яновський. // Інформаційні технології в освіті: Збірник наукових праць. -2010 . - С. 40-46.

5. Семеніхіна О.В., Шамоня В.Г. Віртуальні лабораторії як інструмент навчальної та наукової діяльності // Педагогічні науки: теорія, історія, інноваційні технології. - Суми: Вид-во СумДПУ імені А.С.Макаренка, 2011. №1(11) - C. 341-346.

6. Юрченко А.А. Виртуальные лаборатории в учебной физической среде / А.А.Юрченко // Інформаційні технології в професійній діяльності - 2016. №10. URL: http://e.itvpd.in.ua/index.php/itvpd/article/view/46 


\title{
INCREASING THE CARRYING CAPACITY OF THE PRESSING MECHANISM OF THE ROLLING STATE
}

\author{
Huz Eduard \\ student gr.8.1330 \\ Zaporizhzhia National University
}

At present, in the rolling production, the values of the forces and torques acting on the rolling mills have sharply increased, and the rolling speed has increased. The consequence of the tightening of the operating conditions of the equipment is a decrease in the service life of units and parts and an increase in the number of emergency breakdowns, leading to downtime. Losses of rolling production from accidents are quite large. The breakdown of the rolling equipment leads to downtime, sometimes large, disrupting the rhythm of the work of other shops. Therefore, an increase in the service life of equipment and a decrease in the number of breakdowns due to the correct accounting of the existing loads and the selection of the optimal safety margins of units and parts allows you to obtain a significant economic effect. [1]

One of the most critical units of a rolling mill stand is a pressure mechanism, which determines the performance of the entire rolling mill.

Installation of rolls in the vertical plane on most mills is carried out using a special mechanism with pressure screws, which is also called pressure. On all sheet, strip and swaging mills, the position of the lower roll with chocks and bearings in the working stand is constant. Therefore, the slurry between the rolls is controlled by moving only the upper roll by means of the pressing device. In order to increase the productivity of the rolling mill, the time spent on setting the top roll should be kept to a minimum. Therefore, the movement of the upper roll must take place at a high speed. However, in some mills that roll thin sheets and strip, the speed of movement of the upper roll is limited by the required accuracy of positioning the rolls in a certain position, so this speed must be very low. [2]

To ensure vertical installation of rolls in 4-roll stands of hot and cold sheet mills, three main types of pressure mechanisms are used - electromechanical, hydraulic and hydromechanical. With regard to the stands of thin-sheet rolling mills, all three types of pressure devices are mainly low-speed ones with a speed of movement of a pressure screw or a hydraulic cylinder rod in the range of 0.05-2 $\mathrm{mm} / \mathrm{s}$. This ensures the positioning of the upper rolls during rolling to regulate the roll gap. [3]

The lifting height of the rolls for low-speed electrically driven pushing mechanisms (duo and quarto mills for cold and hot rolling of sheets and strips) is no more than 100 $\ldots 200 \mathrm{~mm}$, and the speed of the upper roll is $<1.0 \ldots 0,2 \mathrm{~mm} / \mathrm{s}$, caused by the need to obtain a small value of the individual displacement (up to $0.01 \mathrm{~mm}$ ), as well as an accurate setting of the rolls. Slow-speed pushing mechanisms have bulky gearboxes with a gear ratio of $1500 \ldots 2000$. As a rule, the electric drive is two-motor, and the possibility of separate movement of the screws is provided (an electromagnetic coupling is installed between the two motors), which is especially necessary for continuous sheet rolling mills. [4] 
The rolling process is associated with high loads and forces arising from plastic deformation of the metal. These loads are transmitted through the work rolls, backup rolls, and roll bearings to the pressure screws of the pressure mechanism of the rolling mill stand. The rolling forces reach tens of meganewtons, and this requires high strength and reliability of the entire push mechanism as a whole.

From the equipment of the push mechanism, the most loaded elements are the push screw-nut and the worm together with the worm wheel, which makes it necessary to constantly increase the strength and wear resistance, to increase the efficiency of the gears in connection with the constantly growing loads. All this requires new solutions and modernization of the equipment used.

Thus, it is proposed to replace the globoid worm gear with a worm gear with a concave worm profile, which are not inferior to globoid gears in terms of load capacity, but have a higher efficiency due to geometric elements that provide a hydrodynamic effect. This transmission is built on the basis of a cylindrical worm, has a concave helicoid profile, the generators of which are respectively arcs of a circle, ellipse, hyperbola and parabola. Such a worm, in contact with the convex surface of the teeth of the worm wheel, forms contact lines of such a shape, in which the conditions for the formation of an oil wedge are significantly improved, which in turn establishes the "carrying capacity" of the pair. The increase in the load capacity of the transmission, operating under conditions of intermittent contact, creates a real reserve of strength for the possibility of reducing the width of the bronze rim of the worm wheel and switching to less expensive materials, using cast iron and graphitized steel as materials for the rims of worm wheels. [5]

\section{References:}

1. Режимы нагружения и прочность прокатных станов. / [В. М. Клименко, Л. В. Коновалов, В. С. Горелик та ін.]. - Киев: Техніка, 1976. - 173 с.

2. Королев А. А. Конструкция и расчет машин и механизмов, прокатных станов: Учеб. пособие для вузов. / А. А. Королев. - М.: "Металлургия", 1985. - 376 с.

3. Жильцов А. П. Листопрокатное оборудование: учеб. пособие / А. П. Жильцов. - Липецк: Изд-во Липецкого государственного технического университета, 2016. - 189 с.

4. Зеленов А. Б. Выбор мощности электропривода механизмов прокатных станов: Учеб.пособие / А. Б. Зеленов. - К.: УМК ВО, 1990. - 200 с.

5. Дубровский Р. И. К вопросу возможности увеличения нагрузочной способности червячных передач / Р. И. Дубровский, А. И. Сапко. // ДМетИ Запорожский филиал. - 1968. - №3. - С. 277-281. 


\title{
WAYS TO INCREASE THE RELIABILITY OF THE BALANCING DEVICE OF THE ROLLING MILL DRIVE
}

\author{
Karmazin Maksym \\ student gr.8.1330 \\ Zaporizhzhia National University
}

The gaps in the connection of the parts of the spindles and the working stand depend on each other in a certain way. Clearances in the joints of spindle parts are one of the main reasons for the appearance of clearances in the system of parts "work roll - bed legs". Spindles, as heavy-loaded mechanisms, wear out quickly, forming gaps in the joints of parts, which contribute to the development of centrifugal inertia force, change the parameters of the deformation zone, and contribute to the wear of chocks, guides and work roll supports. Due to the fact that the working stands in the system of parts "roll - stand of the bed" have gaps, in the field of which the centrifugal force of inertia moves the work rolls, the rolls are skewed relative to the rolling axis. This in the deformation zone causes deviations of the velocity vectors of the metal and rolls from the direction of the rolling speed and causes the deviation of the vectors of the peripheral velocities of the work and backup rolls. All this leads to distortion of the deformation zone and violation of the stability of the rolling process. In this case, axial forces appear, which violate the stability of the process, reduce the rolling accuracy and the operability of bearing supports, wiring and other parts of the working line. [1]

The authors in [2] cite data indicating that in the process of rolling, the roll gap, which changes in connection with the performance of technological operations, and their diameter during transshipment do not fully compensate for the weight of the spindles. This can cause deviations of 30-50\% of the dynamic factor depending on the angular position (horizontal-vertical) of the spindle blade. Thus, even the minimum weight of the spindles, uncompensated within $\pm 5 \%$, leads to a twofold opening of the gaps in one roll revolution. Angular clearances, which open depending on the elasticmass parameters of the mechanical system and the nature of the applied load, can lead to significant dynamic loads in the drive lines and emergency breakdowns, both of the spindles themselves and other equipment of the stands (work roll shanks, gear shafts, couplings, gearboxes). Thus, the imperfection of most designs of balancing devices basically provide the necessary conditions only for mounting spindles and roll couplings. [2]

The main types of balancing devices are known [3]:

- freight;

- hydraulic;

- spring.

At present, the spring balancing of the spindle devices is installed at the 1680 rolling mill of the hot-rolling thin sheet shop. To level all the shortcomings of spring balancing, where the spindle weight compensator in the event of dynamic loads are helical cylindrical springs, it is proposed to install a package of Belleville springs instead of the existing coiled cylindrical springs. 
In addition to performing purely power functions, Belleville springs can actively damp and absorb impact energy (much more efficiently than coil springs). This is due to the fact that in the process of deformation, the supporting edges of the springs slip, which leads to the appearance of significant frictional forces, and absorbing the energy of impact or vibration. Sometimes, to increase the efficiency of damping, flat washers are installed between the supporting surfaces of the plates, along which the edges slide. [4]

As a result of modernization, it is possible to increase the ability to transmit large torques and reduce the downtime of the technological line as a whole, associated with unplanned repairs from the occurrence of gaps in the joints of the spindle units under the influence of dynamic components of the technological load. Also, the proposed modernization will have a positive effect on reducing the wear of the bronze liners of the universal spindles and will reduce the downtime associated with their replacement.

\section{References:}

1. Комаров Н. Н. Шпиндели и муфты с шарнирами на телах качения для тяжелых машин (прокатных станов). Монография. / Н. Н. Комаров. Днепропетровск: Системные технологии, 1998. - 276 с.

2. Крот П. В. Проблемы разработки износостойких демпфирующих вкладышей для шпинделей листопрокатных станов / П. В. Крот, Н. В. Нижник. // Фундаментальные и прикладные проблемы черной металлургии. - 2006. - №13. - C. 298-306.

3. Машины и агрегаты металлургических заводов. Т. 3. Машины и агрегаты для производства и отделки проката: Учебник для вузов / [А. И. Целиков, П. И. Полухин, В. М. Гребеник та ін.]. - М.: Металлургия, 1988. - 680 с.

4. Жук А. Я. Теория и практика приводов. Учебное пособие в 3-х книгах. Кн.2 Гидро- и пневмопривод / А. Я. Жук, Н. К. Желябина. - Запорожье: ЗГИА, 2001. $-220 \mathrm{c}$. 


\title{
APPLICATION OF DEEP LEARNING TECHNOLOGIES FOR BIOSIGNAL PROCESSING
}

\author{
Khoma Yuriy, \\ Ph.D., Assistant Professor \\ Lviv Polytechnic National University \\ Brydinskyi Vitalii, \\ Ph.D Student \\ Lviv Polytechnic National University \\ Artemuk Serhii, \\ Ph.D Student \\ Lviv Polytechnic National University
}

Biosignals carry valuable information, and for more than a hundred years they have been used in medical diagnostics. Development of microelectronics and computer technologies positively influenced the characteristics improvement in medical diagnostics. This favored the growth of domains and tasks, where biosignal analysis discloses new possibilities. Currently various hardware is available for registration and processing of dozens of biosignals aimed to solve of different bioinformatics tasks. Among such tasks the most popular ones include 24-hour clinic monitoring, biometric identification and authentication, control of the psycho-emotional states and reactions of the person, direct interaction of the human with the technical means through the 'brain-computer' interface and bioengineering for neuro-rehabilitation.

Traditionally, for more than a hundred years, biosignals have been used in medical practice to diagnose various diseases. The most common examples are ECG and EEG, but there are dozens of less common techniques - electromyography, vibroarthrography, rheography, photoplethysmography, and others. But despite the long history of development and use in medical applications, computer processing of biosignals plays only a supplementary role in the decision-making process as a recommender software for medical doctors. On the one hand, this is due to legal restrictions related to the high cost of diagnostic errors, and on the other - the need for a large amount of additional knowledge for a comprehensive assessment of a particular situation, which is necessary to make a balanced and correct conclusion. In the near future in the field of medical diagnostics, the expert assessment of medical professionals will continue to be the main criterion for decision-making.

However, there is another, relatively new area of application of biosignals, which is characterized by full automation of the process from the acquisition and processing of biosignals, to the top-level decision determined by the final application objective. Among the most well-known and widespread are non-medical applications of computer processing of biosignals, such as biometrics, affective computer science, 
and biocomputer interfaces. Each of these areas has its own specifics and, in turn, contains a significant number of applications (user cases).

At this time, prospects have matured not only for research but also for the practical implementation and use of technologies based on the computer processing of biosignals. For example, smart prostheses, exoskeletons, portable devices for continuous 24/7 biomedical monitoring, biometric payment systems, etc. have become possible primarily due to the growth of computing power, miniaturization and reduction in the cost of microelectronic devices, the explosive development of the Internet of Things, cloud technologies and artificial technologies. This is confirmed by hundreds of publications that reflect new and new achievements in this area.

Biometrics is a branch of science and technology that aims to recognize people based on their physiological markers, such as fingerprints, voice, palm geometry, and biosignals. Biometrics is widely used in identification and authentication tasks, such as border control, e-commerce, smartphones, cars, and more.

Affective computing is a branch of science and technology that deals with the recognition of psycho-emotional (affective) states of a person, such as fatigue, stress, depression, and so on. Affective computer science is used in lie detectors, mental health monitoring, the computer game industry, personalized marketing, etc.

Neuro-computer interfaces (BCI) are information-measuring systems designed to directly exchange information, usually control commands, between the brain and a computer or robotic device. Currently, the main areas of application of BCI are the development of intelligent prostheses, exoskeletons and other systems for people with mobility issues, as well as rehabilitation after injuries, strokes, mental disorders.

The peculiarity of the tasks of processing biosignals in these applications is the complexity of their formalization due to various factors, such as the low SNR and natural variability of the biosignals in time. As a result, the efficiency of classical algorithms for digital signal processing (DSP) is rather limited.

Therefore, the question of finding new approaches to the development of models, methods, and means of processing biosignals still remains open. One of the most promising approaches in this field is the use of deep learning technologies and artificial neural networks, which have proven to be a powerful tool in solving similar problems in related fields (e.g. computer vision, speech recognition, computational genomics).

As part of the research, a methodology for processing biosignals based on the combined use of DSP and deep learning algorithms was developed and validated. This methodology is based on the following principles:

- modular approach, which allows flexible selection of only the necessary elements, depending on the type of equipment, the nature of the signal and the final application;

- use of optimized DSP algorithms to solve formal tasks (e.g. filtering or decomposition of the biosignal);

- use of deep learning algorithms to solve abstract tasks that are difficult to describ by analytical or other formal models. Typical applications are the detection and elimination of anomalies and outliers, data augmentation, patterns recognition for highlevel decision-making applications (identification of a person, stress level, etc.); 
- since training of deep learning algorithms requires the optimization of a large number of hyperparameters, a system of their automatic selection using the MonteCarlo method combined with predictive modeling based on gradient machines and decision trees is proposed;

- signal fusion to achieve more complex informational representation, for example, the combined use of heart rate and skin sweating to assess stress levels or the shape of the ECG signal and the distribution of bioimpedance for biometric identification.

The proposed methodology for building computerized systems for processing biosignals was implemented in the form of an appropriate software and hardware framework. Its use provides following advantages:

- speed and simplicity of development;

- general-purpose design patterns;

- the possibility of implementation at any of the system levels: sensor (correction of frequency errors of the frequency analyzer bioimpedance), measuring channel (filtering anomalies, elimination of parasitic effects of myograms in EEG and ECG signals), control unit, or decision making (recognition of control commands, providing/denial of access based on the results of identification);

- computational efficiency (a combination of computationally complex deep learning algorithms with optimized DSP-libraries, acceleration of selection of hyperparameters of deep learning models due to prognostic modeling);

- reliability and accuracy (increasing the reliability of identification results, reducing the number of incorrect decisions in control systems and erroneous results of emotion recognition in affective computer science).

ECG biometric identification systems is presented as an example below. DSP algorithms were used to change the sampling rate, filter low-frequency interference (breathing, body movements) and electronics noise. Then a special deep learning algorithm (based on generative neural networks) was used to detect and eliminate abnormal segments in the measurement signal (due to the movements of the electrodes, the influence of muscle contractions, and other factors). After that, the segmentation of the signal into separate intervals corresponding to each heart beat was again performed by standard DSP algorithms. At the last stage, there was a selection of optimal parameters of the network, which carried out the final identification (highlighting the individual characteristics of each user, which allowed to distinguish it from the rest).

In conclusion, it can be argued that deep learning technologies in combination with classical DSP methods (spectral and correlation analysis, FIR and IIR filtering, wavelet transforms) open new perspectives in the field of biosignal processing, as they allow to significantly improve and expand technical and operational characteristics. systems for various applications.

\section{References:}

1. Rangaraj M. Rangayyan. (2002) Biomedical Signal Analysis. A Case-Study Approach. Jhon Willey and Sons Inc. 556 pp. 
2. Singh R.R., Conjeti S., Banerjee R. (2013) Comparative evaluation of neural network classifiers for stress level analysis of automotive drivers using physiological signals // Biomedical Signal Processing and Control. Vol. 8. Pp.740-744.

3. 176. Khoma V., Pelc M., Khoma Y., Sabodashko D. (2018) Outlier Correction in ECG-Based Human Identification. In: Hunek W., Paszkiel S. (eds) Biomedical Engineering and Neuroscience. BCI 2018. Advances in Intelligent Systems and Computing, vol 720. pp 11-22. Springer.

4. Khoma Vю, Pelc M., Khoma Y. Artificial Neural Network Capability for Human Being Identification based on ECG // 23rd International Conference on Methods and Models in Automation and Robotics, Miedzyzdroje, 27-30 August 2018. IDAACS 2018.

4. Karpinski M., Khoma V., Dudykevych V., Khoma Y., Sabodashko D. Autoencoder Neural Networks for Outlier Correction in ECG-Based Biometric Identification // The 4 th IEEE International Symposium on Wireless Systems within the International Conferences on Intelligent Data Acquisition and Advanced Computing Systems. 


\section{ВИКОНАННЯ БУРОВИХ І ЕКСПЛУАТАЦІЙНИХ РОБІТ ПРИ СПОРУДЖЕННІ СВЕРДЛОВИН ГІДРАВЛІЧНОГО РУЙНУВАННЯ І ТРАНСПОРТУВАННЯ}

Ігнатов Андрій Олександрович к.т.н, доцент кафедри нафтогазової інженерії та буріння Національний технічний університет «Дніпровська політехніка»

\section{Шипунов Сергій Олександрович}

асистент кафедри нафтогазової інженерії та буріння Національний технічний університет «Дніпровська політехніка»

Кононов Микита Ігорович

лаборант кафедри нафтогазової інженерії та буріння Національний технічний університет «Дніпровська політехніка»

Навіть поверхневий аналіз прийомів і методів, що застосовуються в гірничовидобувній галузі України і інших держав з розвиненою сировинною базою, свідчить про широке застосування в процесах виймання корисних копалин капітальних гірничих виробок різної номенклатури. Проте, останнім часом спостерігається стала тенденція переорієнтації окремих ланок видобувної промисловості на застосування так званих геотехнологічних методів [1].

Необхідність використання геотехнологічного вилучення корисних копалин викликана як прагненням до скорочення витрат на процеси виймання корисних копалин з надр, так і неможливістю застосування класичних способів виконання гірничих робіт.

Геотехнологічні методи дозволяють переводити корисні копалини на місці залягання в рідкий, газоподібний або дисперсний стан 3 подальшим транспортуванням на земну поверхню за допомогою свердловин.

Свердловинний гідровидобуток (на прикладі будівельних пісків) зводиться до наступних операцій: гідророзчленовування, гідровідбій, гідропідйом, гідротранспорт [2].

Розробка родовищ за гідравлічного видобутку корисних копалин полягає у створення гірничих виробок (в даному випадку їх підкласу - свердловин), які забезпечують доступ до корисних копалин 3 поверхні і призначені для їх подальшої підготовки та розробки [3].

Будівництво геотехнологічних комплексів починається 3 буріння розвідувальних свердловин; за отриманими із їх допомогою даними, проектується техніко-технологічна схема відпрацювання родовища.

Свердловини для гідровидобутку корисних копалин, на відміну від інших, мають доволі значний діаметр 350 - 400 мм (із подальшим розширенням призабійної зони) і глибину до 200 м. 
В табл. 1 наведено орієнтовний геологічний розріз проектованої ділянки родовища будівельного піску.

Таблиця 1

Літологічна характеристика геологічного розрізу проектованої ділянки

\begin{tabular}{|c|c|c|c|c|}
\hline \multirow{2}{*}{$\begin{array}{c}\text { Шкала } \\
\text { глибин, } \\
\text { м }\end{array}$} & \multirow{2}{*}{$\begin{array}{c}\text { Укрупнена } \\
\text { літологічна } \\
\text { характеристика }\end{array}$} & \multicolumn{2}{|c|}{$\begin{array}{c}\text { Максимальна категорія } \\
\text { порід }\end{array}$} & \multirow{2}{*}{$\begin{array}{c}\text { Можливі } \\
\text { ускладнення }\end{array}$} \\
\hline & & $\begin{array}{c}\text { за } \\
\text { твердістю }\end{array}$ & $\begin{array}{c}\text { за } \\
\text { абразивністю }\end{array}$ & \\
\hline $1-3$ & $\begin{array}{c}\text { Суглинок } \\
\text { гумусований }\end{array}$ & Tn $x$ & 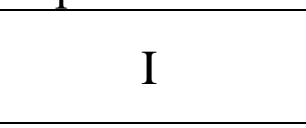 & \\
\hline $4-6$ & $\begin{array}{c}\text { Пісок } \\
\text { дрібнозернистий }\end{array}$ & II & II & Осипи, обвали \\
\hline $7-12$ & Суглинок щільний & III & II & \\
\hline $13-22$ & Глина щільна & IV & II & $\begin{array}{c}\text { Набухання, } \\
\text { звуження } \\
\text { стовбура } \\
\text { свердловини }\end{array}$ \\
\hline $23-29$ & Алеврити & IV & II & $\begin{array}{c}\text { Осипи та } \\
\text { обвалення } \\
\text { стінок } \\
\text { свердловини }\end{array}$ \\
\hline $30-34$ & Глина щільна & IV & II & \\
\hline $35-39$ & $\begin{array}{c}\text { Пісок } \\
\text { середньозернистий } \\
\text { алювіального типу }\end{array}$ & II & II & \\
\hline
\end{tabular}

Аналіз геологічної будови і умов проводки свердловин вказує на те, що ділянка проектованих робіт $\epsilon$ доволі складною 3 точки зору забезпечення раціональних умов відпрацювання родовища. Головна увага в таких умовах повинна бути приділена забезпеченню уникнення будь-яких ускладнень при спорудженні (розвідувальних і експлуатаційних) та експлуатації (добувних) свердловин.

З огляду на зазначене, конструкція розвідувальних свердловин повинна бути запроектована виходячи з умов геологічного розрізу з урахуванням виникнення можливих ускладнень в процесі буріння; вона повинна забезпечувати [4]: повне виконання геологічного завдання; надійну ізоляцію всіх проникних горизонтів і вимоги охорони надр i навколишнього середовища; мінімум витрат на спорудження. Конструкція експлуатаційних свердловин повинна мати [5]: відповідну міцність і довговічність на увесь період роботи; надійну ізоляцію всіх проникних горизонтів (згідно вимог нормативних документів з охорони надр і навколишнього середовища); мінімум витрат на одиницю видобутої продукції; сталі показники досягнення проектних режимів експлуатації; передумови проведення необхідних досліджень. 
Розробка конструкції експлуатаційної свердловини (рис. 2) здійснюється на підставі визначення кінцевого діаметру свердловини (інтервал корисної копалини).

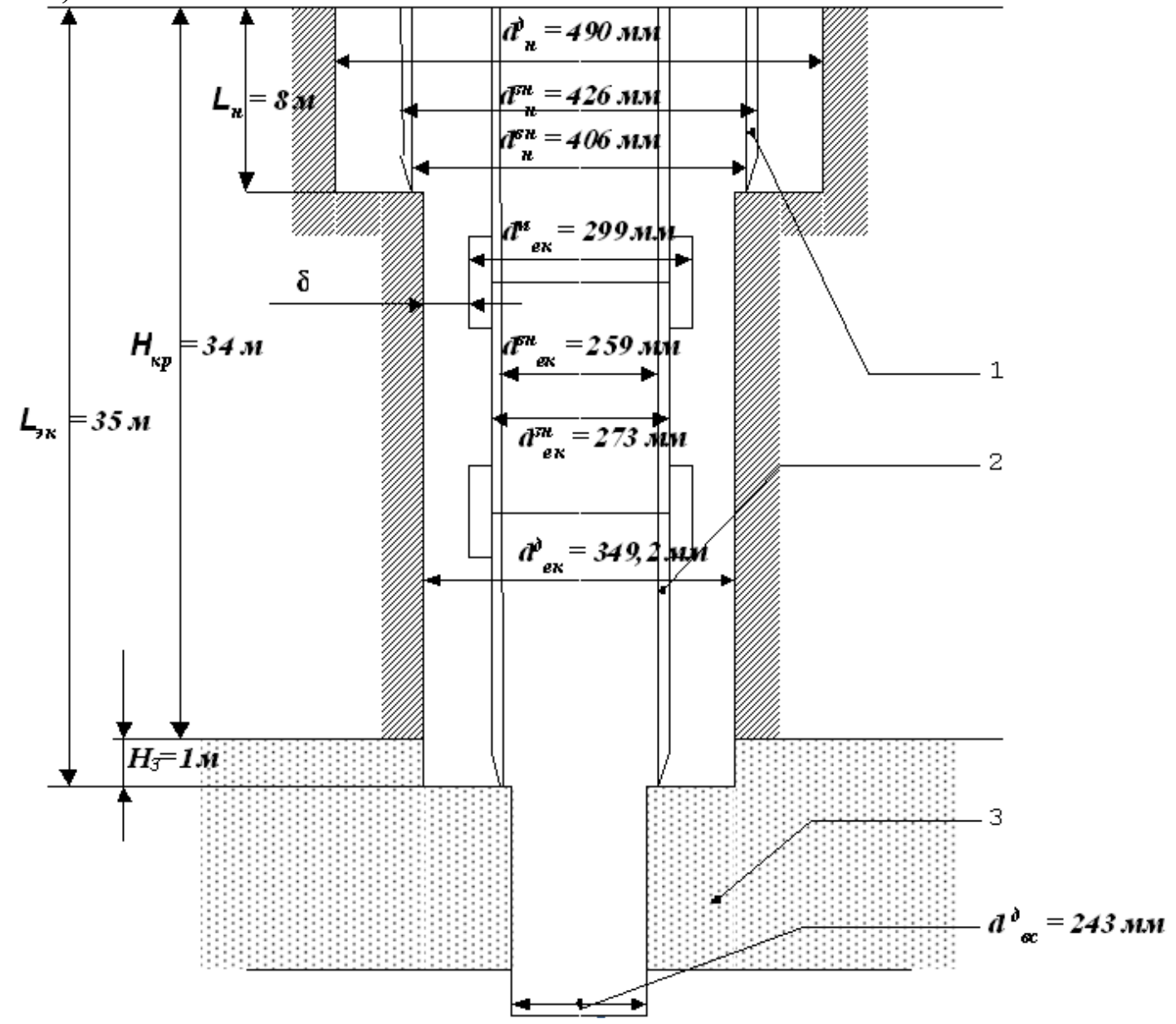

Рисунок 2. Розрахункова конструкція свердловини: 1 - направляюча труба; 2 експлуатаційна колона; 3 - продуктивний горизонт

Система взаємопов'язаних технологічних процесів свердловинного гідравлічного видобутку включає в себе такі важливі складові, як пульпоутворення i всмоктування. Причому режим останнього, практично повністю визначається результатами попереднього, тобто гранулометричним складом зруйнованої породи [6].

Зазначене викликає необхідність комплексного вирішення питання схеми відробки продуктивного масиву, доставки розмитої (зруйнованої) породи до зумпфа ерліфта, створення рухливого стану для гірської маси з урахуванням заданої (або планованої) продуктивності ерліфта.

Для того, щоб частку підняти необхідно зону всмоктування забезпечити механічними або гідравлічними розпушувачами (що зважують частку у всмоктуючому потоці). Гідравлічне розпушування гірської маси навколо всмоктуючого отвору можна ефективно використовувати при роботі підйомної труби ерліфту, зануреної в шар гірської маси. При цьому всмоктуваний потік, перш ніж він поступить в ерліфтну трубу повинен профільтруватися через шар гірської маси (рис. 2) [7]. 


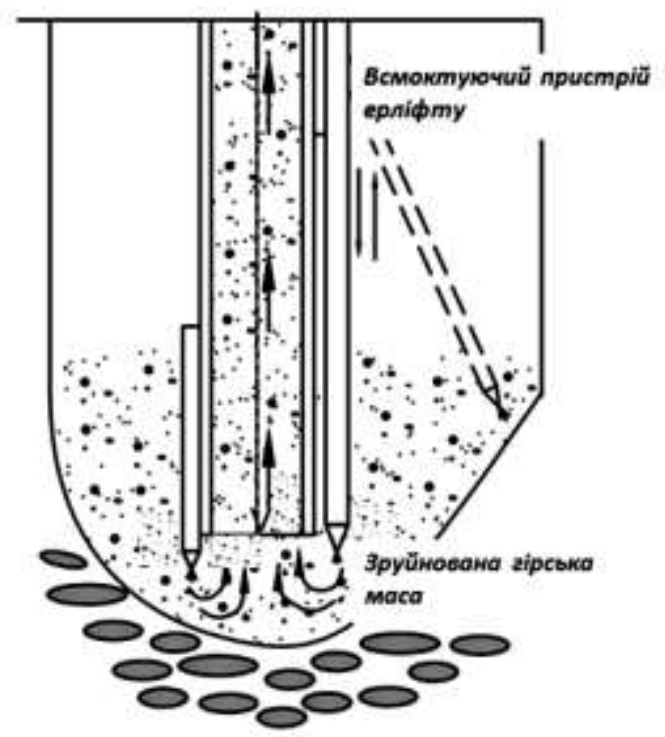

Рисунок 2. Схема ерліфтного гідротранспортування гірської маси

Швидкість фільтраційного потоку, значно більше швидкості потоку при вільному всмоктуванні, де сила потоку діє на частку з одного боку, а сила фільтраційного потоку впливає на частку з усіх боків, у тому числі і співвісної 3 силою ваги частки, тим самим зважуючи іiі, що неможливо при вільному всмоктуванні. Якщо збільшувати продуктивність ерліфта, тим самим підвищуються швидкості фільтраційного потоку від ламінарного режиму через турбулентний до руйнівних швидкостей фільтрації.

Частка піску, при взаємодії 3 потоком рідини, характеризується гідравлічною крупністю, тобто швидкістю падіння у воді. Транспортування часток зруйнованої породи характеризується абсолютною швидкістю частки $V_{4}$, яка пов'язана з середньою швидкістю потоку рідини $V_{p}$ співвідношенням

$$
V_{p}=u+V_{\doteqdot}
$$

де $u$ - швидкість осідання частки шламу в нерухомій рідині, м/с.

Оскільки одна 3 величин $V_{p}$ або $V_{\Psi}$ відома, то для визначення іншої необхідно знайти величину $u$.

Рівняння руху твердої частки складають виходячи із законів механіки: суму усіх сил, діючих на частку, прирівнюють до сили інерції. В умовах гідропідйому це зробити легко, тому, що траєкторія частки відома і напрями дії усіх сил співпадають з напрямом руху частки [8].

На тіло, яке занурюється в необмеженому об'ємі, окрім сили інерції діє сила тяжіння

$$
G_{\grave{O}}=\rho g V,
$$

і Архімедова сила

$$
P_{A}=\rho_{p} g V,
$$

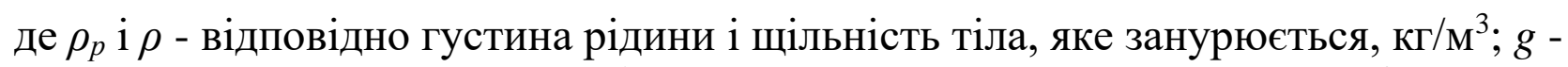

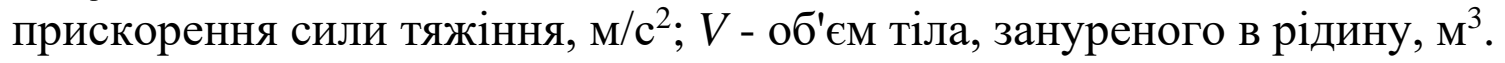

При появі відносної швидкості між тілом і рідиною виникає сила опору 


$$
R=C f \frac{\rho_{p} u^{2}}{2},
$$

де $f$ - площа проекції поверхні тіла на нормаль до вектора швидкості (міделевий переріз), м²; $C$ - коефіцієнт опору, який залежить від форми тіла і режиму обтікання; $u$ - швидкість тіла відносно рідини, м/с.

Рівняння руху тіла під дією цих сил можна записати у виді

$$
G_{T}-P_{A}-R=m_{T} \frac{d u}{d t},
$$

де $m_{T}$ - маса тіла, що рухається у рідині, кг.

Підставляючи значення для $G_{T}, P_{A}$ і $R$ в рівняння (5) отримаємо

$$
m_{T} \frac{d u}{d t}=\rho_{p} g V\left(\frac{\rho}{\rho_{p}}-1\right)-C f \frac{\rho_{p} u^{2}}{2} .
$$

При несталому русі з'являється дія сили інерції, причому розрахунки показують, що тривалість початкового періоду руху тіла із стану спокою зазвичай мала, і його можна не брати до уваги. У загальному випадку розглядають рух сталим і тому силу інерції в рівнянні (6) прирівнюють нулю, тоді

$$
\rho_{p} g V\left(\frac{\rho}{\rho_{p}}-1\right)=C f \frac{\rho_{p} u^{2}}{2} .
$$

Після перетворень з рівняння (7) отримуємо

$$
u=\sqrt{\frac{V}{f}\left(\frac{\rho}{\rho_{p}}-1\right) \frac{2 g}{C}} .
$$

Для частки кульової форми об'єм визначається по формулі

$$
V=\frac{\pi d^{3}}{6}
$$

де $d$ - діаметр кулі, м

Проекцією поверхні тіла у формі кулі на нормаль до вектора швидкості буде круг, площа якого визначається формулою

$$
f=\frac{\pi d^{2}}{4}
$$

Підставивши (10) і (9) в (8), після перетворень отримаємо

$$
u=\sqrt{\frac{4 g}{3 C} d\left(\frac{\rho}{\rho_{p}}-1\right)} .
$$

Як було показано вище, співвідношення (11) отримане з умови, що частки зруйнованої породи мають кулясту форму.

Для розрахунку гідротранспорту пропонується користуватися не залежністю $C=f(\mathrm{Re})$ для кулі, а безпосередньо залежністю величини $C$ від розміру матеріалу, що транспортується. Ця залежність знаходиться шляхом підстановки в рівняння (11) величини $u$ з виразу числа Рейнольдса 


$$
u=\frac{v R e}{d},
$$

де $v$ - кінематична в'язкість рідини, $\mathrm{m}^{2} / \mathrm{c}$.

В результаті підстановки отримаємо

$$
\tilde{N}=\frac{4 g}{3 \operatorname{Re}^{2} v^{2}} d^{2}\left(\frac{\rho}{\rho_{p}}-1\right) .
$$

Задаючись значеннями $C$ i визначаючи величини Re, можна спочатку отримати залежність $C=f(d)$ у вигляді таблиці, а потім побудувати відповідний графік.

\section{Список літератури:}

1. Фізико-хімічна геотехнологія / М.М. Табаченко, О.Б. Владико, О.С. Хоменко, Д.В. Мальцев - Д.: Національний гірничий університет, 2012. $310 \mathrm{c}$.

2. .Маланчук 3.Р., Маланчук Є.3., Корнієнко В.Я. Спеціальні технології видобутку корисних копалин. - Рівне: НУВГП, 2017. - 266 с.

3. Физико-химическая геотехнология / под общей редакцией В.Ж. Аренса. М.: Издательство МГУ, 2010. - 575 с.

4. Кудряшов Б.Б., Яковлев А.М. Бурение скважин в осложненных условиях. - М.: Недра, 1987. - 269 с.

5. Шаровар И.И. Геотехнологические способы разработки пластовых месторождений. - М.: Изд. МГГУ, 1999. - 242 с.

6. Аренс В.Ж. Скважинная добыча полезных ископаемых (геотехнология) / В.Ж. Аренс. - М.: Недра, 1986. - 279 с.

7. Скважинная гидродобыча полезных ископаемых / В.Ж. Аренс, Н.И. Бабичев, А.Д. Башкатов и др. - М.: Изд. МГГУ, 2007. - 295 с.

8. Гейер В.Г., Дулин В.С., Заря А.Н. Гидравлика и гидропривод. - М.: Недра, 1991. - $331 \mathrm{c}$. 


\title{
АСПЕКТИ ФОРМУВАННЯ СПЕКТРІВ ЧАСТОТ ВЛАСНИХ КОЛИВАНЬ ЗУБЧАСТИХ ПЕРЕДАЧ
}

\begin{abstract}
Аль-Амморі Алі, д.т.н., професор, завідувач кафедри інформаційно-аналітичної діяльності та інформаційної безпеки, Національний транспортний університет
\end{abstract}

Дяченко Петро Васильович д.т.н., доцент, доцент кафедри комп’ютерних наук та системного аналізу, Черкаський державний технологічний університет

Хафед I. С. Абдулсалам аспірант кафедри інформаційно-аналітичної діяльності та інформаційної безпеки, Національний транспортний університет

Діагностика вібрацій зубчастих передач часто виконується шляхом аналізу спектру вібрацій. При наявності великої кількості джерел вібрацій, деякі частоти можуть повторюватися від різних джерел. При збігу частот різних джерел, але різної природи такий метод дозволить 3 більшою ймовірністю зробити правильну діагностику редуктора із зубчастими передачами.

Спектральний аналіз дозволяє оцінювати якість зубчастих передач.

1. Зубчаста передача, як лінійна параметрична коливальна система. Зубчаста передача - це коливальна система 3 жорсткістю, що періодично змінюється. Такі системи звуться параметричними.

На рисунку 1 показана одна з розрахункових схем зубчастої передачі, яка застосовується для моделювання динамічних процесів в авіаційних зубчастих передачах.

Кожна пара зубів в моделі замінюється пружністю Cni, похибка профілю Fri, маса коліс J1, J2. Зв'язок між входом і виходом в такій системі встановлюється диференціальним рівнянням, описаним в роботі [1]. 


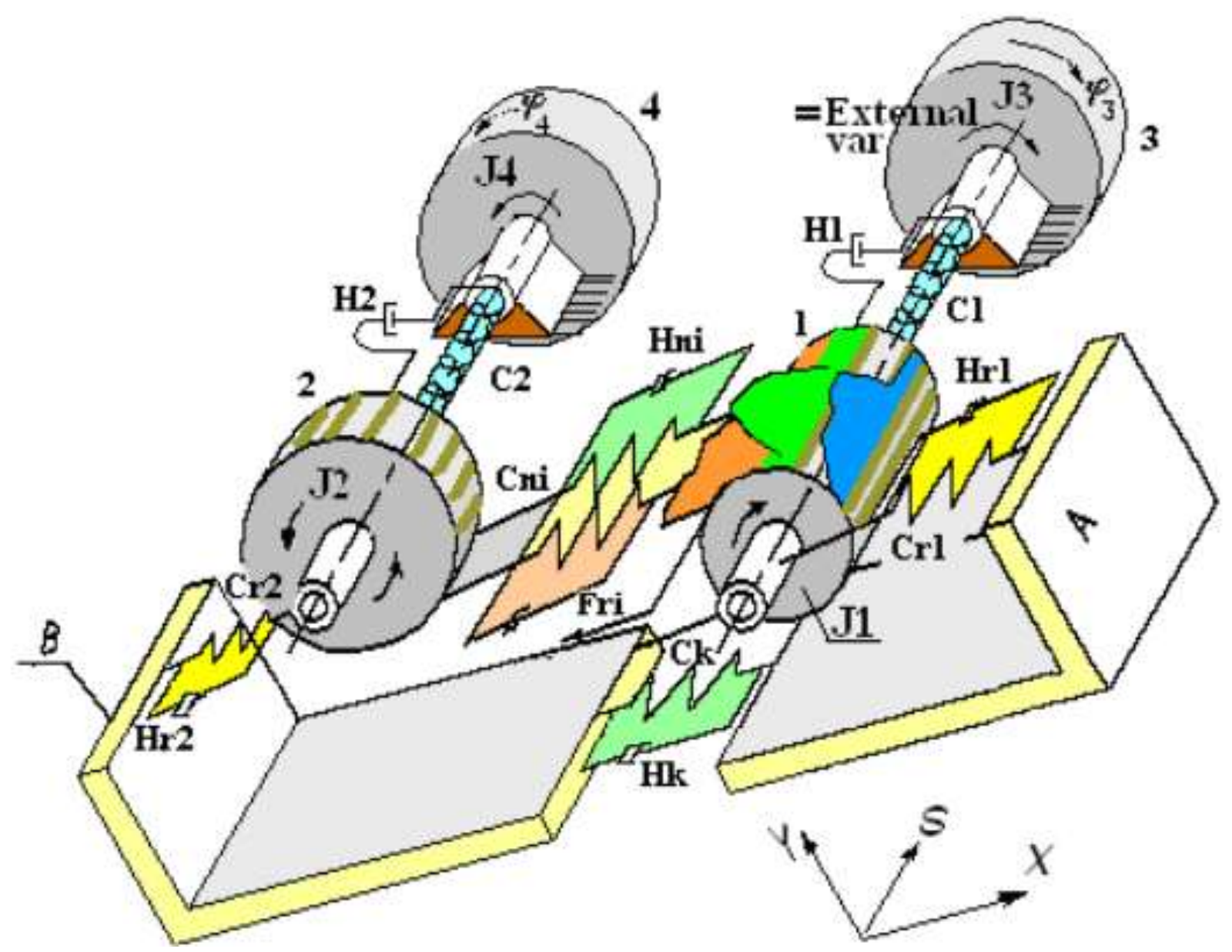

Рисунок 1 - Розрахункова схема моделювання напружень і вібрацій в зубчастій передачі з числом зубів, що періодично змінюються в зачепленні

Для цілей цієї роботи цей зв'язок може бути виражений у спрощеному вигляді:

$$
z(t)=\frac{1}{2 \pi} \int_{-\infty}^{+\infty} S(\omega) K(j \omega, t) e^{j o x} d \omega
$$

де $t$ - час; $\omega$ - частота; $z(t)=x(t)+j y(t)$ - вихідний коливальний процес. Оскільки вираз (1) записано в загальному вигляді, виходом може бути як коливання приєднаної маси $\varphi_{4}(t)$, так і коливання коліс, а також сили, що діють на пружні опори. Символом $j=(-1)^{0,5}$ позначена уявна одиниця, що дозволяє розділити коливання за ортогональними напрямками $S(\omega)$ - спектральна щільність вхідного впливу, що порушує коливальну систему зубчастої передачі. Вхідним впливом може бути як крутильне коливання $f_{3}(t)$, так і похибка профілю зубів Fni $(t) . K(j \omega, t)$ - параметрична передавальна функція коливальної системи, що моделює зубчасту передачу.

Жорсткість зубчастої передачі змінюється по складному закону тому, якщо розкласти параметричну передавальну функцію в ряд Фур'є, вона буде виражатися у вигляді

$$
K(j \omega, t)=\sum_{m=0}^{m=\infty} K_{m}(j \omega) \cos \left(m \omega_{z} t+\psi_{m}\right)
$$


де $\omega_{z}$ - частота пересполучень зубів, m - номер гармоніки зубцевої частоти; $\psi_{m}$ фаза коливань. Аргументами функції (2) є час $t$ i кругова частота. Кругова частота, що має розмірність радіан в секунду, пов'язана 3 частотою коливань, вимірюваних в герцах, співвідношенням $\omega=2 \pi f$.

Метод визначення спектрального складу коливань зубчастої передачі, як параметричної лінійної коливальної системи. Якщо вхідний вплив, наприклад коливання ведучого вала, буде періодичним, то спектральна щільність збудження $S(\omega)$ буде виражатися у вигляді

$$
S(\omega)=2 \pi \delta\left(\omega-\omega_{0}\right)
$$

де $\omega_{0}$ - частота періодичних коливань вхідного впливу;

$\delta($.$) - символ дельта функції Дірака: \delta(0)=\infty, \delta(\neq 0)=0$. Після підстановки виразів (2) і (3) в рівняння (1) множення і інтегрування узагальнених функцій виходить наступний вираз вихідного коливання:

$$
x(t)=\sum_{m=-\infty}^{m=\infty} K_{m}\left(\omega_{0}\right)\left[\cos \left(\omega_{0}+m \omega_{z}\right)\right]
$$

Вираз (4) записано спрощено в дійсній формі тільки для коливань уздовж осі $\mathrm{x}$, спрямованої уздовж лінії зачеплення.

Таким чином, гармонійний спектр коливань зубчастої передачі може містити частоту вхідного коливання, яка модулюється гармоніками пересполучення зубів.

Зубчаста передача, як нелінійна коливальна система. Нелінійні процеси в зубчастій передачі проявляються при геометричному контакті зубів. На рисунку 2 показано, як змінюється циклічна похибка при зміні кінематичної похибки.

Як випливає з результатів моделювання (рисунок 1), якщо зубчасту передачу зібрати 3 ексцентричним зміщенням осей коліс, відповідним дванадцятому ступеню точності, але самі колеса виготовити ідеально точно, то результуюча циклічна похибка буде відповідати дев'ятому ступеню точності по ГОСТ 164381.

Якщо розглядати зубчасту передачу, як параметричну систему, то в такій системі похибка коліс в зачепленні і жорсткість зубів повинні залежати від часу. Фактично функції похибки і жорсткості залежать не від часу, а від кута повороту колеса. Тому в строгому формулюванні зубчата передача - це нелінійна система. Але оскільки кут повороту пов'язаний з часом майже лінійно, багато дослідників розглядають зубчасту передачу як лінійну. Однак це передбачає, що кожному позитивному $\Delta \mathrm{t}$ має зіставлятися також позитивне $\Delta \varphi(\mathrm{t})$ при постійному коефіцієнті пропорційності між часом і кутом повороту. Очевидно, що ця умова ніколи не дотримується. 


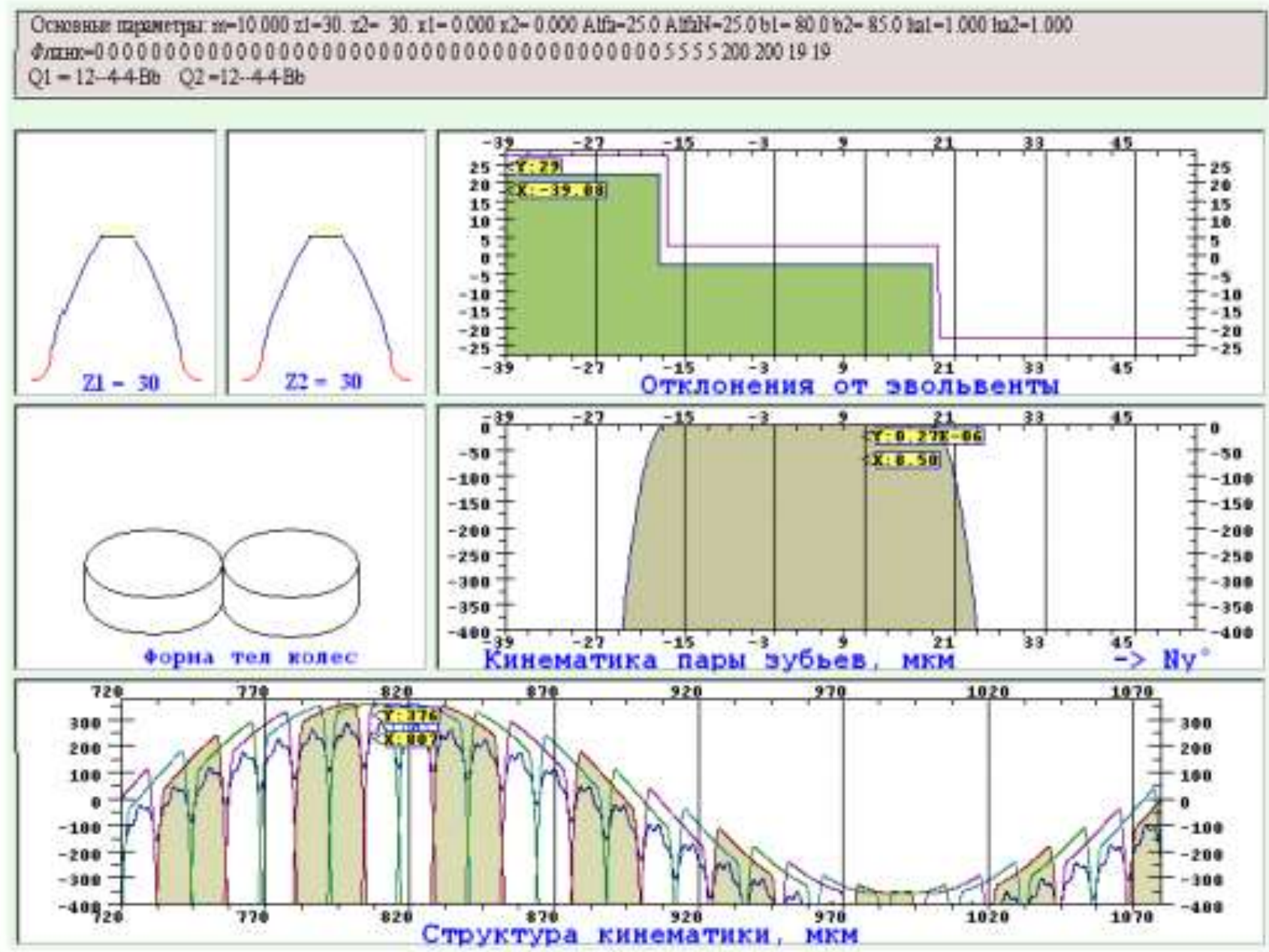

Рисунок 2 - Результат моделювання кінематичної похибки зубчастої передачі

Жорсткість зубчастої передачі це також нелінійна функція. Якщо складова жорсткості зубів лінійно залежить від навантаження, то контактна жорсткість має нелінійну залежність, особливо в фазах керамічного зачеплення.

За перерахованими причинами математична модель зубчастої передачі повинна будуватися як нелінійна. Саме така модель реалізована в комп'ютерних програмах типу AsGears.

Поблизу резонансних областей роботи передачі зуби коліс можуть розмикатися і заглиблюватися, жорсткість зубів в зачепленні при відриві зубів буде дорівнювати нулю. В цьому випадку зубчата передача $\epsilon$ вираженою нелінійної системою. 3 теорії нелінійних $[2,3]$ систем слідує, що зубчаста передача буде коливатися по наступному закону:

$$
x(t)=\sum_{m=-\infty, n=-\infty}^{m=\infty, n=\infty} K_{m}\left(n \omega_{0}\right)\left[\cos \left(n \omega_{0}+m \omega_{z}\right)\right]
$$

Так, якщо зубчата передача $z 1=z 2=30$ має частоту обертання 1500 об / хв і $\epsilon$ лінійною параметричною системою, то за формулою (4) в спектрі коливань можуть бути присутніми наступні частоти коливань: 25 Ц, 750Гц, 725Гц, 775Гц,

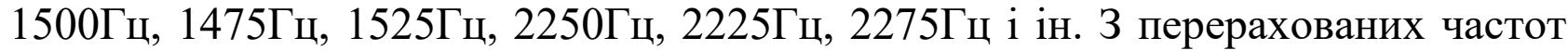
зубцевою, тобто частотою пере сполучення зубів, є частота 750Гц. Але, якщо зубчата передача коливається як нелінійна система, то крім перерахованих 
частот будуть частоти 50Гц, 75Гц, 100Гц, 125Гц, 150 Гц і ін. Такі, наприклад як 1550 Цц, 2300Гц і ін.

Таким чином, якщо користуватися якісним аналізом, то спектр можливих коливань досить широкий і щільний.

\section{СПИСОК ВИКОРИСТАНОЇ ЛІТЕРАТУРИ}

1. Yu J. Y., Shi D.W., Li,Z., Yu S. Y.,\& Zhang, Y. (2019). Experimental Study on Repairing Large Modulus Rack Cracks by Argon Arc Welding. Materials Science Forum, 943, 8-13.doi:10.4028/www.scientific.net/msf.943.

2. Uekita M., \& Takaya, Y. (2016). On-machine dimensional measurement of large parts by compensating for volumetric errors of machine tools. Precision Engineering, 43, 200 -210.doi:10.1016/j. precisioneng. 2015.07.009.

3. Wang H., Ma, G., Xu, B., Yong, Q., \& He, P. (2017). Design and application of friction pair surface modification coating for remanufacturing. Friction, 5(3), 351-360. doi:10.1007/s40544-017-0185-3. 


\title{
ОБЛІПИХА - ФУНКЦІОНАЛЬНИЙ ІНГРЕДІЕНТ ПРИ ВИГОТОВЛЕННІ ВАРЕНИХ КОВБАСНИХ ВИРОБІВ
}

\author{
Басараб Ірина Михайлівна, \\ кандидат сільськогосподарських наук, доцент, \\ доцент кафедри технології м'яса, м’ясних та олійно-жирових виробів \\ Львівського національного університету ветеринарної медицини та \\ біотехнологій імені С. З. Гжицького
}

М'ясна галузь являється важливою складовою частиною агропромислового комплексу України й одним із найбільших сигментів продовольчого ринку. Приблизно $25 \%$ продукції, що випускається м’ясопереробними підприємствами, займають варені ковбасні вироби, тому внесення в їх рецептуру функціональних інгредієнтів являється одним iз перспективних шляхів розширення асортименту продуктів функціонального призначення [1].

Споживання варених ковбасних виробів функціонального призначення дозволяє знизити дефіцит мікронутрієнтів шляхом підбирання рецептурних компонентів і введення природних концентратів біологічно активних речовин (БАР) [1, 2]. В якості джерела таких природних концентратів БАР можна розглядати ягідну культуру - обліпиху. Основним продуктом переробки ягід обліпихи являється обліпихова олія, побічним продуктом - залишаються насінини. Насіння обліпихи володія високою харчовою цінністю, але широко не використовується в харчовій промисловості $[3,4]$.

Дані про хімічний склад насіння обліпихи наведені в таблиці 1.

Таблиця 1.

Хімічний склад насіння обліпихи дикорослої

\begin{tabular}{|l|c|}
\hline \multicolumn{1}{|c|}{ Показники } & Вміст, \% \\
\hline Білок & $20,06 \pm 1,15$ \\
\hline Жир & $12,07 \pm 0,65$ \\
\hline Вуглеводи, в т.ч.: & \\
$\quad$ целлюлоза & $14,21 \pm 0,68$ \\
$\quad$ пектин & $2,46 \pm 0,05$ \\
$\quad$ крохмаль & $0,51 \pm 0,55$ \\
$\quad$ моно- і дисахариди & $1,25 \pm 0,52$ \\
\hline Мінеральні речовини & 3,3 \\
\hline Флавоноїди & $1,54 \pm 0,06$ \\
\hline
\end{tabular}

3 представлених даних випливає, що насіння обліпихи $є$ природним концентратом білків, жирів і вуглеводів. Аналіз хімічного складу насіння показав, що насіння містить значну кількість харчових волокон.

Одним із раціональних шляхів використання насіння різних культур в харчовій промисловості являється їх попереднє пророщення. Насіння обліпихи замочували при температурі (18-20) ${ }^{\circ} \mathrm{C}$ протягом 24 год. до вологості (36-38) \% i пророщували протягом 10 діб при температурі (20-25) ${ }^{\circ} \mathrm{C}$ до вологості $47 \%$. 
На рисунку 1 представлений графік пророщування насіння обліпихи в порівняльному аспекті з зернами ячменю.

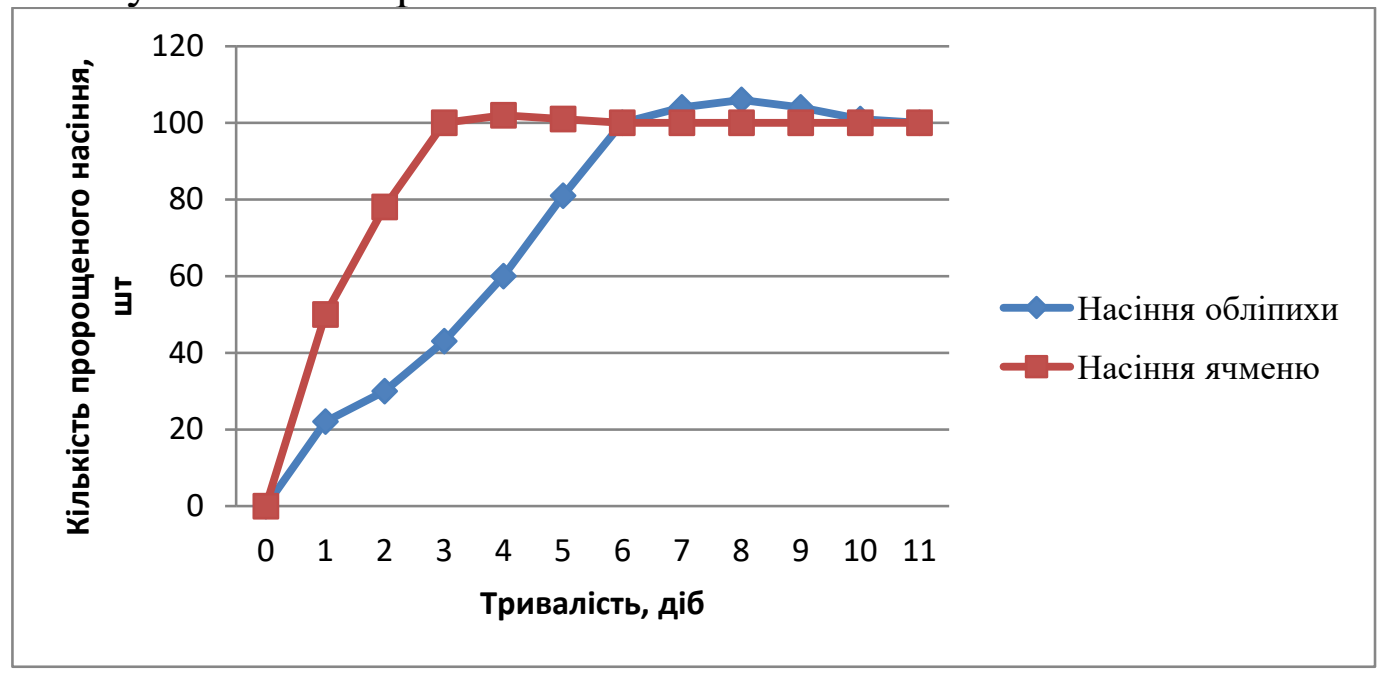

Рис. 1. Динаміка пророщення насіння обліпихи і зерен ячменю

3 даних, представлених на рисунку 1, випливає, що для насіння обліпихи енергія проростання і рівень схожості в 3 рази менше, ніж для ячменю і становить 6 днів. Це обумовлено морфологічним складом насіння, зокрема, високою міцністю оболонки, в основному складається 3 целюлози, вміст якої в обліпиховому насіння становить $18,1 \%$.

В результаті активації фізіологічних і біохімічних процесів у пророщеному насінні накопучуться БАР [5]. Тому дослідження хімічного складу i функціональних властивостей пророщених насінин обліпихи та їх застосування у технології варених ковбасних виробів $є$ доцільним.

Пророщене насіння обліпихи характеризується специфічним олійним присмаком і більш насиченим коричневим відтінком. Борошно із пророщененого насіння обліпихи (БПНО) характеризується наступними показниками: вологість - не більше 9,0 \%, зольність - не більше 3,15 \%, крупність, залишок на ситі № 067 - не більше $2,0 \%$.

Хімічний склад борошна 3 пророщеного насіння обліпихи представлений в таблиці 2.

Як свідчать дані таблиці 2, вміст білків при пророщуванні насіння обліпихи збільшується на 6,4 \% в порівнянні з їх вмістом в борошні з нативного насіння. Відзначено зменшення в БПНО кількості високомолекулярних полісахаридів целюлози - на 2,06 \%, крохмалю - на 0,86 \%, при незначному збільшенні вмісту моно- і дисахаридів на $0,56 \%$. Обліпихове насіння $є$ джерелом ліпідів. Встановлено, що при пророщування вміст ліпідів знизився на 2,4\%.

Таблиця 2.

Хімічний склад БНО і БПНО

\begin{tabular}{|l|c|c|}
\hline \multicolumn{2}{|c|}{ Показники } & \multicolumn{2}{|c|}{ Вміст } \\
\cline { 2 - 3 } & БНО & БПНО \\
\hline Волога,\% & $10,64 \pm 0,12$ & $10,21 \pm 0,94$ \\
\hline Білки,\% & $35,06 \pm 0,14$ & $41,40 \pm 0,13$ \\
\hline Ліпіди,\% & $21,40 \pm 0,75$ & $19,00 \pm 0,68$ \\
\hline
\end{tabular}




\begin{tabular}{|l|c|c|}
\hline Вуглеводи, \%, в т. ч.: & $18,21 \pm 0,61$ & $16,15 \pm 0,52$ \\
целюлоза & $3,46 \pm 0,07$ & $3,18 \pm 0,05$ \\
пектин & $1,71 \pm 0,05$ & $0,85 \pm 0,06$ \\
крохмаль & $2,29 \pm 0,07$ & $2,95 \pm 0,04$ \\
моно- і дисахариди & $6,21 \pm 0,08$ & $5,95 \pm 0,11$ \\
\hline Мінеральні речовини,\% & 478 & 464 \\
\hline Енергетична цінність, ккал &
\end{tabular}

Отже, БПНО володіє високим енергетичним потенціалом, оскільки містить значну кількість білків, жирів і вуглеводів. Воно має високу харчову цінність, яка характеризується наявністю ненасичених жирних кислот, водо- i жиророзчинних вітамінів, в тому числі антиоксидантної дії.

При формуванні структурно-механічних і функціонально-технологічних властивостей фаршевих систем особливе значення має вміст структуроутворювачів - полісахаридів в системі та їх якісний склад. 3 властивостями полісахаридів зв'язані взаємодія вуглевод-вода, вуглевод-ліпіди, тому водо- i жироутримуючі здатності являються одним із обов'язкових показників оцінки функціонального інгредієнта для виробництва варених ковбасних виробів [6].

Традиційно використовується борошно пшеничне у технології варених ковбас, особливістю якого являється висока водозв'язуюча і гелеутворююча властивості.

Результати дослідження функціонально-технологічних властивостей БПНО представлені в таблиці 3.

Таблиця 3.

Водо- і жироутримуючі здатності БПНО

\begin{tabular}{|c|c|c|}
\hline Сировина & ВУЗ,\% & ЖУЗ,\% \\
\hline $\begin{array}{l}\text { Борошно } 3 \text { насіння } \\
\text { обліпихи }\end{array}$ & $126,86 \pm 1,12$ & $72,32 \pm 1,15$ \\
\hline БПНО & $148,24 \pm 5,21$ & $80,54 \pm 1,76$ \\
\hline Борошно пшеничне & $116,17 \pm 3,14$ & $59,23 \pm 1,22$ \\
\hline
\end{tabular}

БПНО характеризується збільшенням на 21,4 \% ВУЗ і на 8,2 \% ЖУЗ, що пояснюється збільшеною кількістю білків при пророщенні насіння обліпихи та зміною структури високомолекулярних полісахаридів.

Таким чином, БПНО зв'язує воду за рахунок білкової системи i полісахаридів, у результаті чого підтримується стабільність форми варених ковбас, знижуються втрати при тепловій обробці, підвищується сочність готового продукту та збільшується вихід продукції.

\section{Список літератури:}

1. Пересічний, M.I. Технологія продуктів харчування функціонального призначення [Текст] / За ред. М.І. Пересічного. // 2008. - К: КНТЕУ. - 718 с. 
2. Доценко В.А. Теоретические и практические проблемы питания здорового и больного человека [Текст] / В.А. Доценко // Вопросы питания. - 2014. - № 6. С. 36-39.

3. Золотарева, A.M. Перспективы совершенствования производства продуктов питания на основе биологически активных веществ облепихи / А.М. Золотарева // Известия вузов. Пищевая технология. - 2003. - № 4. - С. 55-57.

4. Чиркина Т.Ф. Пути использование семян облепихи на пищевые цели / Т.Ф. Чиркина, Г.В. Габанова, А.М. Золотарева // Успехи современного естествознания. - 2004. - № 2. - С. 56-57.

5. Сімонова I.I. Удосконалення технології напівкопчених ковбас 3 використанням сочевиці та пряно-ароматичних рослин: автореф. дис. ... канд. техн. наук : спец. 05.18.04 «Технологія мясних, молочних продуктів і продуктів 3 гідробіонтів» / Сімонова Ірина Іллівна; НУХТ. - К., 2018. - 24 с.

6. Клюкина, О.Н. Исследование функционально-технологических свойств вареных колбасных изделий с порошком семян тыквы / О.Н. Клюкина, Е.В. Кунташов, Н.М. Птичкина // Хранение и переработка сельхозсырья. - 2012. № 9. - С. 35-37. 


\title{
ВИЗНАЧЕННЯ ВИМОГ ДО ОНЛАЙН СИСТЕМИ АДАПТИВНОГО ТЕСТУВАННЯ ЗНАНЬ СТУДЕНТІВ
}

\author{
Борисова Наталя Володимирівна \\ к.т.н., доцент кафедри інтелектуальних комп'ютерних систем \\ Національний технічний університет \\ «Харківський політехнічний інститут»
}

Кочусва Зоя Анатоліївна к.т.н., доцент кафедри інтелектуальних комп'ютерних систем Національний технічний університет «Харківський політехнічний інститут»

\section{Плєхова Ганна Анатоліївна}

к.т.н., доцент кафедри інформатики та прикладної математики Харківський національний автомобільно-дорожній університет

В умовах загального переходу на дистанційне навчання, викликаного пандемією, увага до систем комп'ютерного тестування знань студентів значно збільшилася. Незважаючи на те, що багато компаній пропонують власні розробки у цій сфері, мало хто з них реалізує адаптивну модель тестування, яка $\epsilon$ більш прогресивною, ніж традиційна модель, тому що адаптуючись під попередні відповіді студента, дозволяє оцінити реальний рівень його знань, через те, що проходження тестування цілком залежить від рівня компентності студента 3 питань певної дисципліни, хоча викладачеві необхідно докласти більше зусиль при підготовці такого тесту, через те, що питання необхідно розподілити за рівнями складності. Отже, здійснивши грунтовний аналіз предметної області вдалося визначити вимоги до власної системи адаптивного тестування знань студентів відповідно до категорій користувачів:

- $з$ боку викладача: велика база та різноманітність тестових завдань; можливість встановлення для питань рівня складності; можливість додавати формули, символи та малюнки у питання та відповіді; встановлення обмежень за часом для проходження тесту; обмеження доступу студентів до тестів; можливість відстроченої публікації тестів; доступність усіх результатів проходження тестів $з$ дисципліни студентами;

- 3 боку студента: можливість тестування після успішної реєстрації; перегляд усіх своїх результатів проходження тестів;

- для обох груп користувачів: видача результатів одразу; інтуїтивно зрозумілий та дружній інтерфейс.

Щодо типів питань, доступних у системі тестування, будуть доступні як питання закритого типу, так і питання відкритого типу.

Питання закритого типу:

- Чи згодні Ви з твердженням? Студенти мають обрати серед двох варіантів відповіді: Так чи Нi 
- Які показники групи Б відповідають показникам групи А? Студенти мають знайти відповідність між показниками двох груп.

- Оберіть декілька правильних відповідей із запропонованих. Студенти мають обрати декілька правильних відповідей до поставленого запитання.

- Оберіть одну правильну відповідь із запропонованих. Студенти мають обрати одну правильну відповідь до поставленого запитання.

Питання відкритого типу:

- Дайте коротку відповідь. Студенти мають вписати у відповідне поле у якості відповіді слово або словосполучення.

Як показав аналіз літературних джерел, цих типів питань цілком достатньо для формування адаптивних тестів з будь-яких дисциплін. 


\section{ОСОБЛИВОСТІ РОБОТИ ГІДРОЦИЛІНДРА ЗАХВАТНОГО ОРГАНУ}

Гулісва Наталія,

к.т.н., доцент

Луцький національний технічний університет

\section{Пастернак Вікторія,}

к.Т.Н., доцент

Луцький національний технічний університет

Самчук Людмила,

к.т.н., доцент

Луцький національний технічний університет,

м. Луцьк, Україна

Збільшення числа природних стихійних лих і різних аварій вимагає застосування універсальної техніки, призначеної для виконання складних робіт, наприклад, маніпулятора із захватом [1].

Для проектування захватного органу маніпулятора показано розрахункову схему (рис. 1), де $\mathrm{P}$ - зусилля на штоку гідроциліндра; $\mathrm{N}$ - сила для утримання об’єкта маніпулювання; 1 - відстань до центру захвату.

Для даного виду захватного пристрою відповідає рівність $\frac{\mathrm{P}_{\Perp}}{\mathrm{N}}=\frac{41}{\mathrm{~d}}$, звідки:

$$
\mathrm{P}_{\mathrm{L}}=\frac{41 \mathrm{~N}}{\mathrm{~d}}
$$

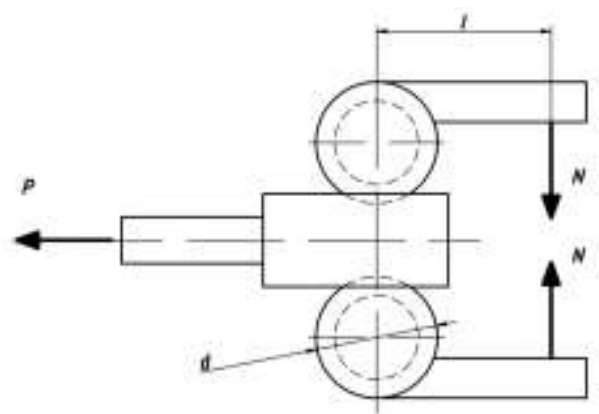

Рисунок 1. Схема роботи гідроциліндра

В даному випадку, для забезпечення утримання об'єкта необхідно, щоб сила тертя кінцівок і об'єкта дорівнювала вазі вантажу [2], тоді $\mathrm{F}=\mathrm{G}=\mathrm{N} \times \mu$, звідси:

$$
\mathrm{N}=\frac{\mathrm{G}}{\mu},
$$

де $\mu$ - коефіцієнт тертя; $\mu=0,3$. 


$$
\mathrm{N}=\frac{19,6 \cdot 10^{3}}{0,3}=65,3 \kappa \mathrm{H} .
$$

Розміри $\mathrm{d}$ i 1 - визначаємо конструктивно [3].

$\mathrm{D}=120 \mathrm{MM}, 1=264 \mathrm{mм}$.

Обчислюємо необхідне зусилля гідроциліндра:

$$
\mathrm{P}_{\text {и }}=\frac{4 \cdot 0,264 \cdot 65,3 \cdot 10^{3}}{0,12}=574,64 K H .
$$

Знайдемо розмір гідроциліндра:

$$
\mathrm{d}_{\text {ц }}=\sqrt{\frac{4 \cdot 574,64 \cdot 10^{3}}{3,14 \cdot 25 \cdot 10^{6}}}=0,17 \text { м. }=170 \mathrm{MM} .
$$

Приймемо діаметр гідроциліндра за ДСТУ 3455.2-96 $\mathrm{D}_{\text {ц }}=180$ мм; $\mathrm{d}_{\mathrm{II}}=50 \mathrm{MM}[4]$.

Було виконано ряд розрахунків для проектування захватного органу, які необхідні для виконання умов міцності, відповідно до яких конструкція маніпулятора відповідає вимогам необхідних для роботи в спеціальних умовах.

\section{СПИСОК ЛІТЕРАТУРИ:}

1. Гулієва Н.М. Мобільний робототехнічний комплекс крокового типу / Н.М. Гулієва, О.С. Рускевич, Т.В. Гордій // Міжнародна наукова інтернетконференція на тему «Інформаційне суспільство: технологічні, економічні та технічні аспекти становлення» (випуск 53), 16 листопада 2020 року. Частина 2. - С. 49- 50.

2. Губарев А.П. Механотроника: от структуры системы к алгоритму управления: учеб. пособие / А.П. Губарев, О.В. Левченко. - К.: НТУУ «КПИ», 2007. $-180 \mathrm{c}$.

3. Huliieva N.M., Somov D.O., Pasternak V.V., Samchuk L.M., Chetverzhuk T.I. The selection of boron nitride circles for grinding saponite titanium composites using non-parametric method. Latvian Journal of Physics and Technical Sciences. Riga, Latvia, 2020, Vol. 57(6). P. 68-77.

4. ДСТУ 3455.2-96. Гідроприводи об ємні та пневмоприводи. Частина 2. Об`ємні гідромашини та пневмомашини. Терміни та визначення (ISO 5598:1985, NEQ) 


\title{
НАПРУЖЕНО-ДЕФОРМОВАНИЙ СТАН ОБОЛОНОК РАКЕТНИХ КОНСТРУКЦИЙ
}

\author{
Кравцов Віктор Іванович, \\ доктор технічних наук, професор, \\ Київ, Національний авіаційний університет
}

Сучасний рівень технічного прогресу дозволяє створювати машини i конструкції, які мають високу надійність. Основою для цього слугує комплекс заходів, застосовуваних на стадіях проектування, виготовлення, монтажу й експлуатації. На стадії проектування — це вибір раціональних конструктивних схем і матеріалів, належний розрахунок з урахуванням усіх впливів, які можуть виникнути в процесі експлуатації. Усунення прихованих дефектів на стадії обкатування й приробітки, система технічного обслуговування, що включає комплекс діагностичних і планово-профілактичних заходів, дозволяють знизити до мінімуму ймовірність виникнення відмов у процесі експлуатації. Таким чином, найбільш актуальною стає проблема прогнозування й забезпечення технічного ресурсу конструкцій. Розв'язок цієї проблеми передбачає встановлення якісних і кількісних закономірностей, що визначають ресурс.

Проблема міцності баків ракетних конструкцій завжди була актуальною у зв'язку з безперервним удосконаленням їх конструкцій. 3 метою зменшення їх ваги особливо важливим $\epsilon$ робота матеріалу баків у пластичній стадії до руйнування. Складні й важкі режими роботи систем пов'язані, як правило, 3 необхідністю спеціального вивчення й визначення діючих на них сил, урахування сильної нелінійності розв'язальних рівнянь, можливості втрати стійкості рівноваги й з вимогою дослідження поведінки системи в закритичних станах. Дослідження цих процесів вимагає створення нових і модернізування відомих математичних моделей i алгоритмів, що дозволяють, при певних допущеннях, оперативно визначати напружено-деформований стан за допомогою бортових комп'ютерних систем. Як правило, ракетні баки являють собою конструкції з ускладненою геометричною структурою. Складний обрис їх осьової лінії в довільному часовому відрізку експлуатації викликаний різними факторами, зокрема функціональним призначенням конструкції. Розв'язок таких задач виявляється можливим тільки сучасними методами нелінійного аналізу, застосування яких спонукає до вибору модифікації розв'язальних рівнянь, що забезпечують алгоритмічність i ефективність використовуваних підходів. Дотепер зазначені дослідження не одержали необхідного розвитку через відсутність достовірних математичних моделей, які могли б досить просто й ефективно реалізовуватися у вигляді алгоритмів i програм для числового розв'язку розглянутих задач.

Щоб визначити напружено-деформований стан оболонки, використовується, як правило, безмоментна теорія пружних оболонок. Існує безліч методик розрахунків оболонок різних конструкцій. Як правило, всі вони мають дуже складні аналітичні або чисельні алгоритми, ряд допущень, що знижують точність 
обумовлених величин. У даній роботі пропонується метод визначення напружено-деформованого стану оболонок, заснований на кінцево-елементній розбивці конструкції на кільцеві елементи, який у порівнянні з існуючими значно підвищує швидкість та точність обчислень, алгоритмічність переходу 3 одних умов задачі до інших. Розглядається напружено-деформівний стан окремого кільця або його частини у його пружному деформуванні. Знаючи напружено-деформований стан (НДС) кожного кільця, можна дати характеристику НДС усієї оболонки в цілому як сукупності деформованих кілець, що пов'язані між собою початковими умовами.. Для визначення характеристик НДС у просторовому необмеженому деформуванні окремого кільця застосовується методика, що розроблена професором В.І.Кравцовим [1].

У даній роботі розглядаються питання напружено-деформованого стану баків ракетних конструкцій при дії статичних, квазістатичних або динамічних навантажень. За базову модель пропонується методика дослідження деформування гнучких просторово скривлених елементів, що докладно описана в [2]. У плані застосування сучасних обчислювальних алгоритмів вона дозволяє створити уніфіковані методи дослідження, які дозволяють ураховувати:

- необмеженість просторового пружного деформування;

- фізико-геометричні параметри елементів 3 довільними уздовж осі значеннями згинальних і крутильних жорсткостей;

- дію статичних, квазістатичних або динамічних навантажень, що як завгодно розташовані у просторі;

- дію випадкових

Запропонована математична модель базується на відомих підходах Лагранжа й Ейлера, які описують рівновагу й деформування гнучкого елемента, його зовнішню й внутрішню геометрію. Методика розв'язання поставленої задачі, що складає 18 звичайних диференційних рівнянь, заснована на сумісному використанні методу продовження по параметру й методу НьютонаКанторовича. Побудова матриць Якобі на кожному кроці варіювання параметра навантаження здійснюється методом Рунге-Кута четвертого порядку. Кількість кроків інтегрування й точок дискретизації по довжині елемента залежить від багатьох факторів: кількості й характеру діючих по довжині навантажень, нелінійності процесу тощо.

Слід зазначити, що всі способи завдання навантажень і крайових умов реалізуються обчислювальними алгоритмами, тобто, величини сил і моментів, точки їх додавання тощо, визначаються автоматично, програмісту досить задати їхню величину у вихідних даних.

Враховуючі, що чисельна методика дозволяє досліджувати об'єкт в стадії нелінійного необмеженого деформування, опишемо метод дослідження НДС у залежності від графіку руйнування матеріалу.

Звичайно параметри кривої руйнування у чисельному розв'язку в якості початкових умов задаються функціонально. Але сучасні програмні алгоритми дозволяють "оцифровувати" будь-яку криву, тобто, обчислювати іiї просторові координати. Підставляючи такі дані кривої та іiї похідні, можна прослідковувати 
характеристики напружено-деформованого стану об'єкту від початку пружного деформування до руйнування.

Для перевірки результатів чисельного дослідження просторового деформування кільця був проведено послідовно декілька експериментів. Спочатку верифікувалася достовірність розрахунку окремого кільця у його необмеженому просторовому пружному деформуванні. Гнучке кільце навантажувалося зосередженим навантаженням посередині дискретно за кроками. Границя пружного деформування кільця перевірялася шляхом його навантаження в максимально можливих межах, при яких переміщення точок кільця досягали величин, порівнянних з його діаметром; і після зняття сил, що викликають деформування, кільце поверталося у вихідне положення. Це свідчить про відсутність пластичних деформацій.

Переміщення точки посередині кільця після кожного навантаження визначалося фотограмметричним методом. У такий спосіб на фотовідбитку можна простежувати еволюцію просторового деформування при кожному етапі навантаження. Вимірявши в заданому масштабі переміщення, можна судити кількісно про ступінь просторового деформування кільця. Фіксування форми кільця після кожного етапу навантаження виконувалося в один фізичний момент, зйомка проводилася 3 однієї точки. При цьому використовувалася фотозйомка методом накладення одного кадра на іншій, для того щоб одержати всі форми кільця при кожному етапі навантаження на одному кадрові, що дозволяє крім компактності отриманих результатів фотографування точніше переводити натурні величини у відстані на знімках.

Практика використання пакета прикладних програм для розв'язків тестових задач і експериментальної перевірки розроблених методів і алгоритмів показала, що для достатньої впевненості у вірогідності одержуваних результатів необхідно переконатися в збіжності інтегрування розв'язальних рівнянь. Одним з таких ознак $\epsilon$ візуальне спостереження за допомогою комп'ютерної графіки за геометрією досліджуваного об'єкта безпосередньо в процесі розв'язку на будьякому кроці інтегрування. Якщо 3 якихось причин (неправильно обрані початкові умови, неправильно задані навантаження, неправильно обрана величина кроку навантаження тощо) задача чисельно не вирішується, то це, крім програмного контролю, відразу відображається на дисплеї комп'ютера у вигляді нелогічно розташованих геометричних форм елемента. Якщо ж еволюція форм досліджуваного об'єкта відповідає логіці (зберігаються еволюція правильних геометричних обрисів осьової лініі), то це, як правило, говорить про правильність процесу чисельного розв'язку, контрольований, зрозуміло, i іншими методами за допомогою ЕОМ (величина нев'язок, значення контрольних фізичних величин тощо).

Остаточною верифікацією методики було навантаження реальної оболонки внутрішнім рівномірним тиском. При певних фізико-геометричних характеристиках оболонки i величини внутрішнього тиску визначалися всі характеристики іï НДС при зміні тиску від нуля до деякого значення. На рис. 1 показані значення згинальних моментів на деяких покрокових значеннях тисків. Аналіз рисунка 1 показує, що зі збільшенням внутрішнього тиску на деякому 
етапі значення згинальних моментів мають трохи нелінійний характер, і задача вимагає додаткового дослідження в рамках пропонованого методу. Слід зазначити, що вихідними даними можуть бути будь-які характеристики НДС у табличному вигляді та у вигляді комп'ютерної графіки, отриманої за результатами чисельного розв'язку.

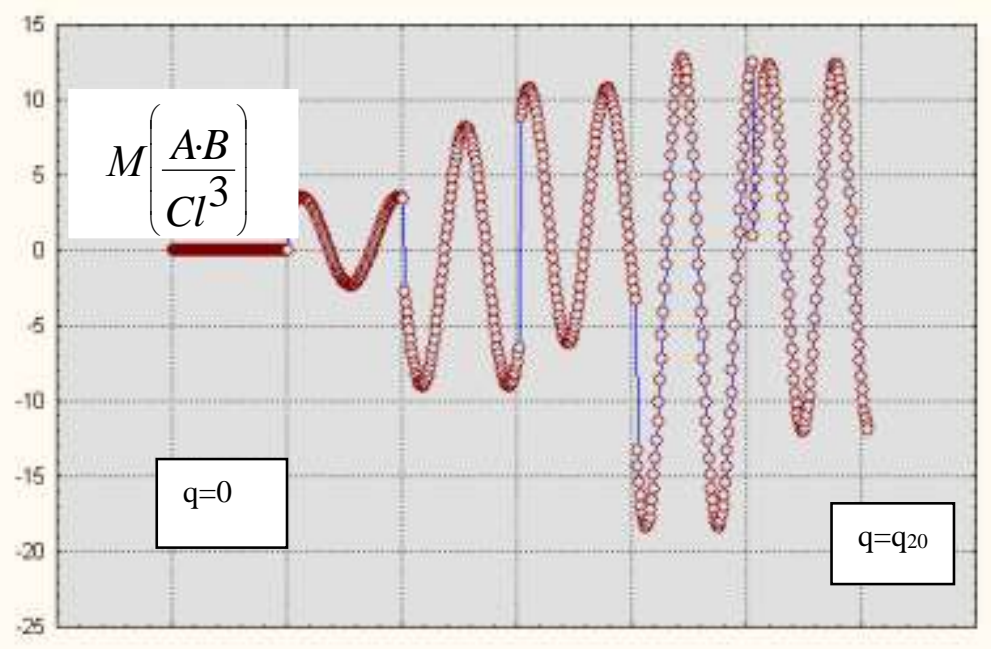

Рис. 1. Згинальні моменти в окремо взятому елементі оболонки

3 використанням пропонованого підходу можливий розрахунок оболонок ракетних конструкцій довільної геометричної форми й серединної поверхні 3 урахуванням нелінійності пружного процесу деформування 3 подальшим переходом до пластичного деформування та до руйнування. При цьому при отриманих за допомогою чисельного розрахунку даних можливий розрахунок несучої здатності конструкції й прогнозування ऑiі працездатності. Метод відрізняється значною алгоритмічністю та точністю.

\section{Список літератури:}

1. Кравцов B.I. Метод численного исследования пространственного деформирования стального каната с учетом межвиткового трения/ Проблеми тертя та зношування, №3- 2016, с. 25-34.

2. Кравцов В.И. Нелинейное деформирование гибкого протяженного стержневого кольца ступенчатой жесткости /Киев. инж.-строит. ин-т.-Киев, 1988.-16с. Деп в УкрНИИНТИ 13.04.88, № 912 -Ук88. 


\title{
ЗАСОБИ ОБЧИСЛЕНЬ ДЛЯ ВЕБ-ОРІЕНТОВАНИХ СИСТЕМ ЕЛЕКТРОННОЇ КОМЕРЦЇ̈
}

\author{
Крепич Світлана Ярославівна, \\ кандидат технічних наук, доцент кафедри комп’ютерних наук \\ Західноукраїнський національний університет

\section{Співак Ірина Ярославівна} \\ кандидат технічних наук, доцент кафедри комп’ютерних наук \\ Західноукраїнський національний університет
}

Позитивні зміни в економіці та законодавстві більшості країн світу створюють сприятливі умови для комерції усіх рівнів та видів. Завдяки спрощенню процесу доставки товарів закордон та мінімізації витрат на розмитнення товарів, продавати свої товари за межі конкретної країни можуть не лише промислові гіганти, але й звичайні підприємці. Даний процес слугував поштовхом для нової хвилі розвитку електронної комерції, адже в умовах сучасного світу дедалі більше користувачів надають перевагу саме їй. В більшості випадків, «електронний» бізнес є вигідним не лише для споживачів послуг, але й постачальників. Дані клієнтів, їхніх замовлень, аналіз вподобань; асортимент та наявність продуктів - усі ці важливі дані зберігаються в одному місці, надійно захищені та добре структуровані. Однак, важко уявити інтернетмагазин, у якому будуть відсутні файли, наприклад: картинки продуктів, подарункові сертифікати, рахунки замовлень тощо [1].

Проблема управління медіа-файлами знайома усім власникам та адміністраторам веб-сайтів та онлайн-магазинів, однак особливо гостро іiі відчувають саме останні. Це пов'язано зі специфікою таких магазинів, адже практично усі сутності мають файли того чи іншого формату: продукти мають зв’язки із зображеннями в галереї; замовлення мають зв'язки із файлами для завантажування; користувачі магазину можуть налаштовувати аватари у своїх облікових записах, завантажувати файли зі своїх замовлень, обмінюватися файлам на форумах, у коментарях чи приватних повідомленнях.

Зрозуміло, що керувати такою кількістю файлів у “ручному” режимі не зручно та небезпечно, адже можна порушити зв’язок між сутністю та пов'язаними із нею файлами. Саме для підвищення продуктивності та безпечності цього процесу було створено вищезгадану систему управління медіа-файлами. 3 часом виникла потреба у підвищенні іiі продуктивності і було прийнято рішення щодо необхідності використання паралелізму у веборієнтованій системі.

3 огляду на те, що апаратне забезпечення досягнуло піку своєї продуктивності, доступного на даному етапі загального розвитку суміжних технологій, а поширення та потреба в обчислювальній потужності веборієнтованих систем продовжують зростати, використання паралелізму при розробці та модернізації систем даного типу можна вважати єдиним способом 
збільшення продуктивності останніх без надмірних витрат на купівлю та утримання обладнання, а також прискорення обробки даних загалом.

У зв’язку з тим, що чимало державних структур вирішили створити сервіси, які надають громадянам можливість отримати інформацію або певні послуги у режимі он-лайн, суттєво зросло навантаження, що припадає на їхні сервери. Через це виникають різноманітні затримки та збої у роботі цих систем, адже кількість користувачів зростає швидше, ніж оновлюється апаратне забезпечення даних систем, а також проявляються недоліки проектування бізнес-логіки чи реалізації певних алгоритмів опрацювання даних [1].

Цілком логічним вирішенням даної проблеми $є$ рефакторинг існуючих систем з подальшим розпаралеленням деяких алгоритмів, що використовуються у даних системах. Це дозволить уникнути витрат на постійне оновлення апаратного забезпечення, зменшити час опрацювання запитів громадян, спростити масштабування та підвищити загальну надійність і відмовостійкість систем, виключивши можливі проблеми із надмірною кількістю «заліза» сукупність цих позитивних змін переважає негативні враження від суми коштів, які можуть бути витрачені на модернізацію вищезгаданих систем.

Деякі вирішення типових проблем, які можуть виникнути при створенні веборієнтованої системи, що використовує паралельні алгоритми опрацювання даних можуть виявитися корисними для подальшої модернізації вищезгаданих систем.

Для створення системи було використано мови програмування РНР та Javascript. Основна логіка програми будується за допомогою РНР, а користувацька частина реалізовувалась за допомогою JavaScript [2-4].

Першим кроком у створенні даної системи було створення файлу конфігурації системи та коду, який з ним працює.

$<$ ?php

define('CSV_FOLDER', 'csv');

define('DOWNLOAD_FOLDER', './download');

define('PACK', 25000);

define('PROCESS', 10);

define('PROXY_ACTIVE', false);

define('PROXY_SERVER'， '173.208.9.167:55320， 173.44.50.83:55320， 8.29.123.138:55320， 142.234.102.11:55320, 167.160.114.152:55320, 37.10.110.136:55320');

define('PROXY_AUTH', 'cart2cart:gAXePJL2bWeXuQ4X');

define('API_PATH', 'https://app.shopping-cart-migration.com/api.get.files.copy.queue/');

define('API_KEY', 'VBHCV1jbcP1HPRk9h6K1kj4ZWE1NVwy5');

Головний контролер системи відповідає за усі функції: вибір файлів для завантаження, перегляд завантажених файлів та їхнього статусу, перегляд звіту по завантажених файлах тощо. Контролер та усі маршрутизатори створювалися самостійно, адже для того, щоб зробити систему максимально «легкою» та досягнути можливості встановлення практично на будь-який сервер чи ПК, було вирішено відмовитися від використання фреймворків.

У цьому контролері відбувається не лише виклик потрібних методів для, на приклад, завантаження файлів, але й підготовка майбутньої структури на новому сервері для файлів, що завантажуються, цим файлам встановлюються потрібні права та за потреби змінюються назви. Останні маніпуляції здійснюються у випадку наявності в назвах файлів спеціальних символів, які є неприпустими у UNIX системах чи конкретних платформах для електронної комерції. 
Основний метод програми, який буде виконувати роль «ядра» та буде викликатися в кількох потоках, має назву «downloadImage». Нижче наведено його код:

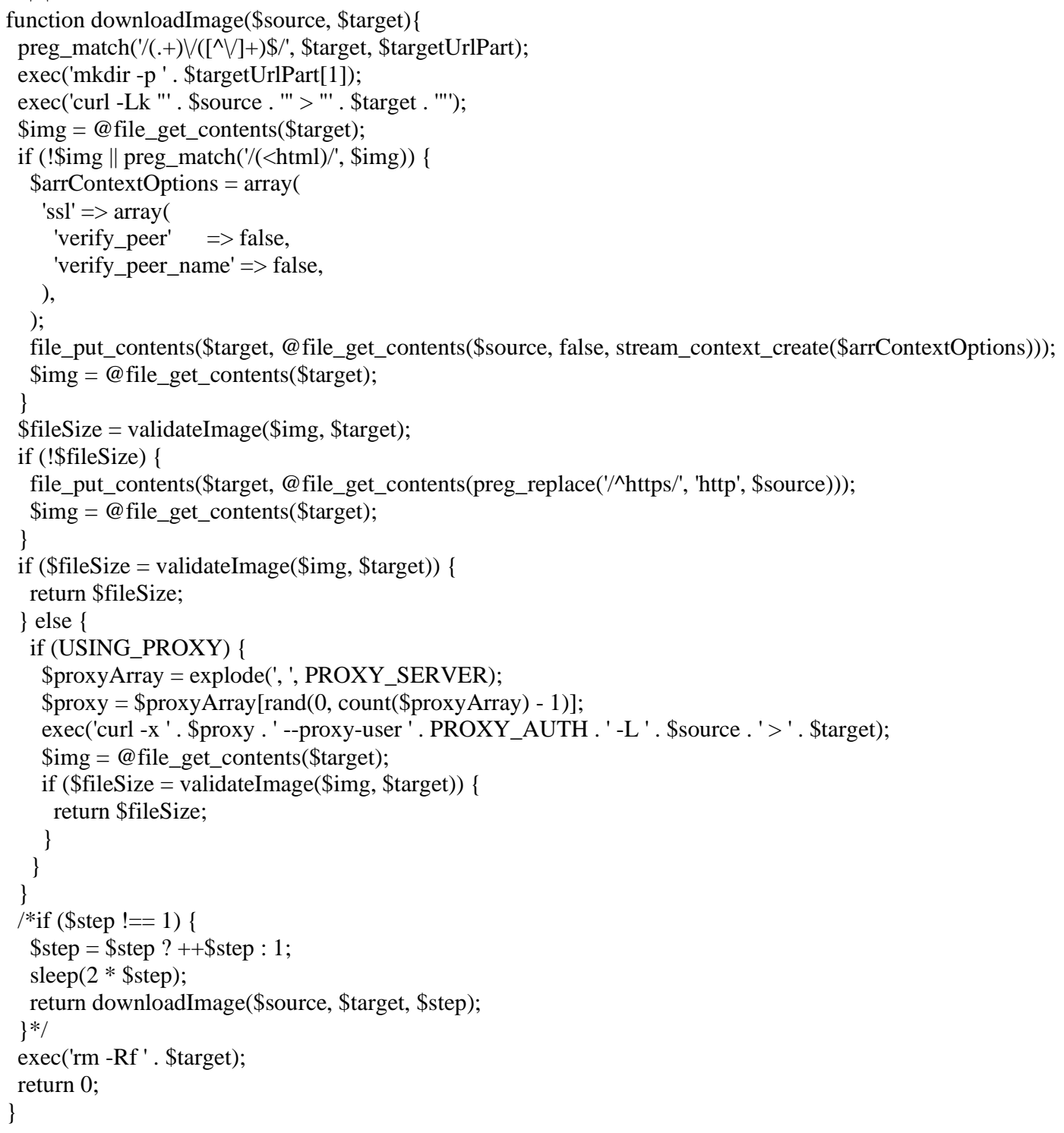

Параметри, що приймає цей метод мають назву source та target та відповідають за старе та нове розташування файла. На випадок блокування зі сторони сервера, у ньому передбачено використання проксі-серверів із адресами, які гарантовано не будуть заблоковані. Звісно, у такому випадку швидкодія процесу дещо знижується, однак процес продовжує коректно виконувати свою роботу не залежно від того, блокує його сервер, чи ні.

Всередині цього метода викликається інший метод, який має назву validateImage. Даний метод використовується для перевірки доступності та валідності файла, що завантажується.

У випадку виникнення потреби у зміні типу файла, викликається метод convertImg, лістинг коду якого наведено нижче.

function convertImg(\$target)\{

\$image $=$ false;

switch(preg_replace('/*ı.([a-z]+)\$/', '\$1', strtolower(\$target))) \{

case 'gif':

\$image = imagecreatefromgif $($ \$target $)$;

break;

case 'png': 


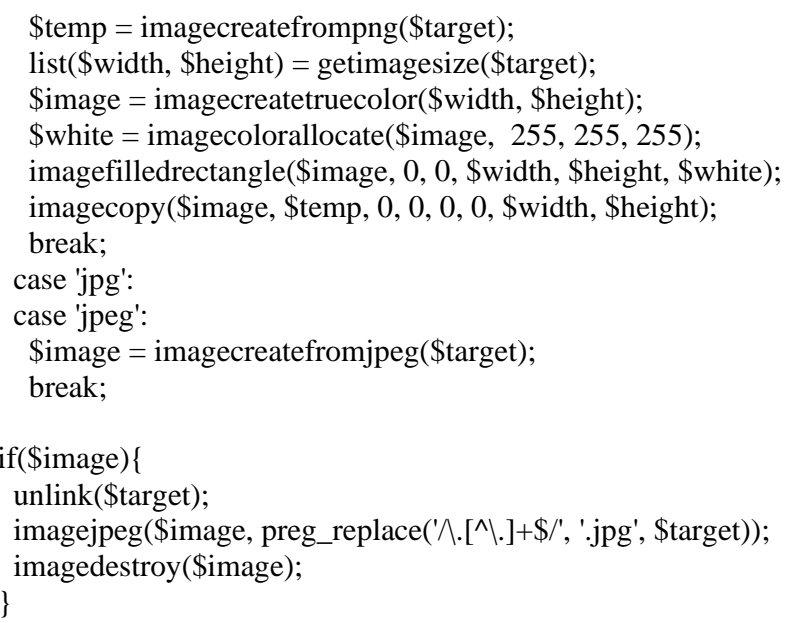

Після завершення обробки своєї порції даних кожен потік записує звіт про процес завантаження кожного файла у загальний лог. Після завершення загального процесу завантаження усіх файлів, часткові логи об'єднуються в один загальний лог та зберігаються в базі даних. Крім збереження в базі даних, лог може бути завантажений користувачем у форматі CSV файла - формат, котрий $\epsilon$ відмежовувальним форматом для представлення табличних даних, у якому поля відокремлюються символом коми та переходу на новий рядок. Поля, що містять коми, декілька рядків або лапки (позначаються подвійними лапками), мають обмежуватися 3 обох боків лапками. Для створення цього файла в системі передбачено метод, який викликається в головному контролері.

Тепер, коли «паралельна» версія даної системи готова, можна порівняти іiі продуктивність 3 «лінійним» попередником [5].

Для тестової вибірки буде використано каталог, який містить 1000 .png файлів, розмір яких не перевищує 2 Мб.

Основними характеристиками для порівняння будуть час виконання завантаження файлів та рівень навантаження на центральний процесор.

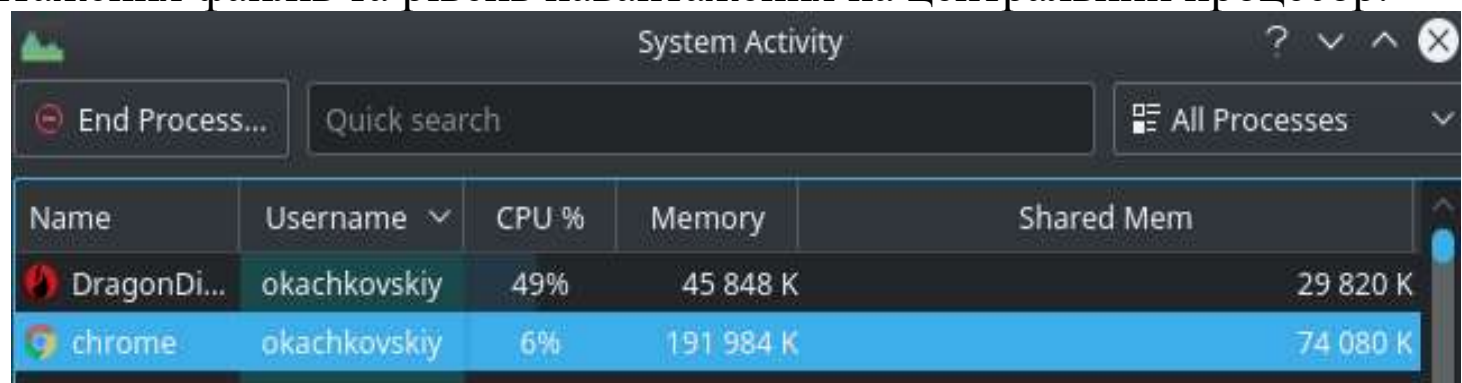

Рисунок 1. Навантаження на ПК за умови послідовного завантаження 1000 файлів.

Завдяки даному порівнянню вдалося з'ясувати, що використання багатьох потоків не лише прискорює процес завантаження файлів, але й дозволяє зменшити навантаження на центральний процесор ПК на 50\%. Враховуючи те, що тестова вибірка містила лише 1000 файлів, то в більших масштабах дана модернізація забезпечить більший приріст ефективності даної системи та дозволить заощадити більше ресурсів. 


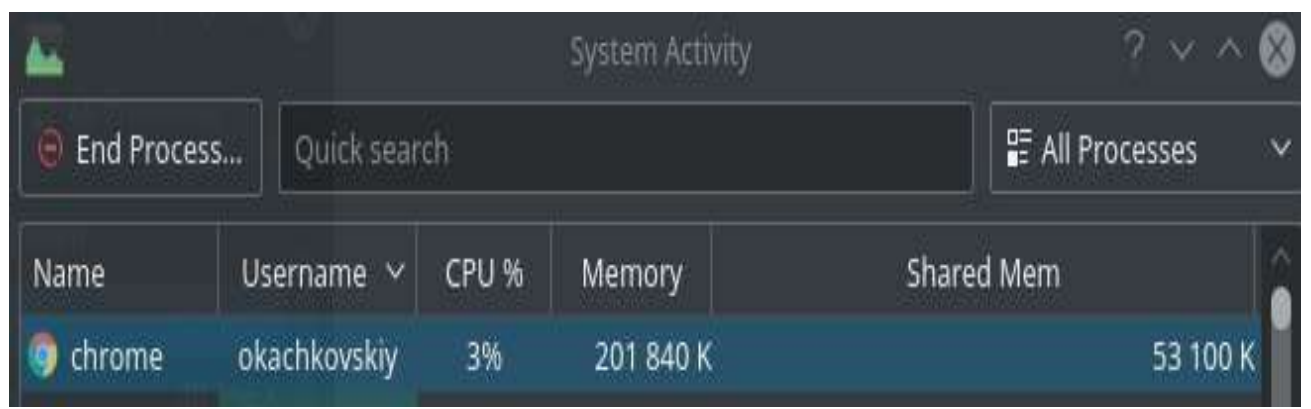

Рисунок 2. Навантаження на ПК за умови паралельного завантаження 1000 файлів.

На рисунку 3 зображено вигляд головного вікна системи під час процесу завантаження файлів.

На цій сторінці користувач може переглядати статистику про:

1) кількість активних процесів;

2) загальний прогрес процесу завантаження файлів;

3) обрані опціі;

4) загальний розмір завантажених файлів;

5) розміщення каталога із файлами.

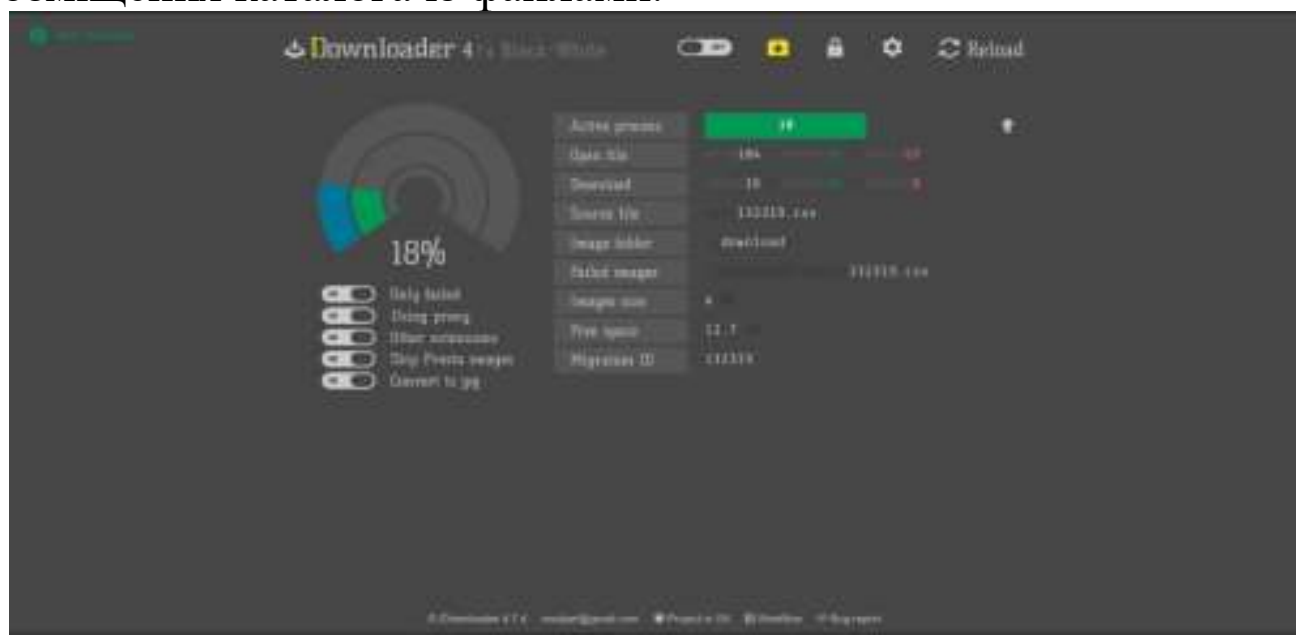

Рисунок 3. Вигляд головного вікна системи під час завантаження файлів

У роботі розглянуто спосіб оптимізації веб-орієнтованої системи для управління файлами інтернет-магазинів, створеної із використанням технології РНР за допомогою використання багатьох потоків. Із порівняння використання ресурсів ПК видно, що використання багатьох потоків не лише прискорює процес завантаження файлів, але й вдвічі зменшує навантаження на центральний процесор ПК.

\section{Список літератури:}

1. Saas E-commerce - https://virtocommerce.com/glossary/saas-ecommerce

2. PHP Manual - https://www.php.net/manual/en/index.php

3. Code Project - https://www.codeproject.com/questions/171271/file-getcontents-url-failed-to-open-stream

4. Code Review - https://codereview.stackexchange.com/questions/80508/imageupload-handler-with-random-filename-generator-and-postprocessing 
5. Качковський О. В. Веб-орієнтована система для управління медіа-файлами інтернет-магазинів / О.В.Качковський, С. Я. Крепич // Комп’ютерні науки та інформаційні технології: Матеріали семінару CSIT'2018 - Тернопіль: THEУ, 2018. - C. 32-33. 


\title{
ВАЛКОВАЯ РАЗЛИВКА-ПРОКАТКА АЛЮМИНИЕВЫХ СПЛАВОВ
}

\section{Нурадинов Абди Сайдахматович,} доктор технических наук, профессор, Грозненский государственный нефтяной технический университет имени акад. М.Д.Миллионщикова

\section{Кондратьев Юрий Иванович,} доктор технических наук, профессор, Северо-Кавказский горно-металлургический институт (государственный технологический университет)

\begin{abstract}
Нурадинов Ибрагим Абдиевич, соискатель, Северо-Кавказский горно-металлургический институт (государственный технологический университет)
\end{abstract}

Благодаря своим уникальным функциональным свойствам алюминиевые сплавы системы $\mathrm{Al}-\mathrm{Cu}-\mathrm{Mg}$ стали важнейшим конструкционным материалом в авиации и космонавтике, то есть в высокотехнологичных областях машиностроения. Вопрос оптимизации технологии производства изделий из таких сплавов является актуальным в связи с необходимостью повышения весовой отдачи крупногабаритных конструкций, которые находятся в сложнонапряженном состоянии и подвергаются воздействию коррозионной среды, а также знакопеременным нагрузкам. Одной из наиболее перспективных в этом плане является технология валковой разливки-прокатки алюминиевых сплавов рассматриваемой системы с получением листовой заготовки, которая сразу прокатывается на тонкий лист [1-3].

В настоящей работе проведено исследование по изучению возможности валковой разливки сплава Д16, который является наиболее распространенным представителем группы алюминиевых сплавов системы $\mathrm{Al}-\mathrm{Cu}-\mathrm{Mg}$ [4-6]. Разливка сплава проведена на двухвалковой установке с наклоном к горизонту под углом 45 градусов (рис. 1 a). В результате получена литая лента с исследуемого сплава Д16 толщиной до 3,5 мм и шириной до 500 мм, которая сразу же в горячем состоянии прокатывалась с разной степенью обжатия (рис. 1 б). Термическая обработка образцов проводилась с учетом данных дифференциальнотермического анализа по различным схемам. На каждой стадии технологической цепочки «валковая разливка - горячая прокатка - термическая обработка» исследована микроструктура и определены механические свойства сплава Д16. Определено влияние технологических параметров на количественные характеристики структуры, в частности: Е - долю интерметаллидных фаз; D размер кристаллов интерметаллидов; А - параметр формы интерметаллидов, 
который определяли как соотношение большего размера кристалла к меньшему, $\mathrm{R}$ - размер дендритных ячеек, $\mathrm{Ar}$ - параметр формы дендритных ячеек.

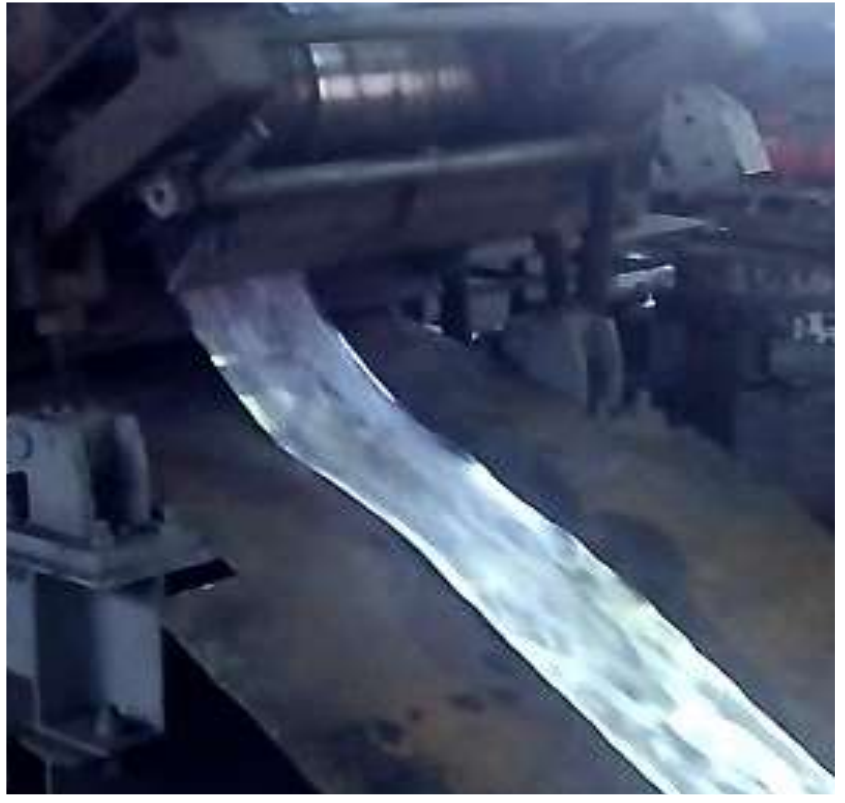

$a$

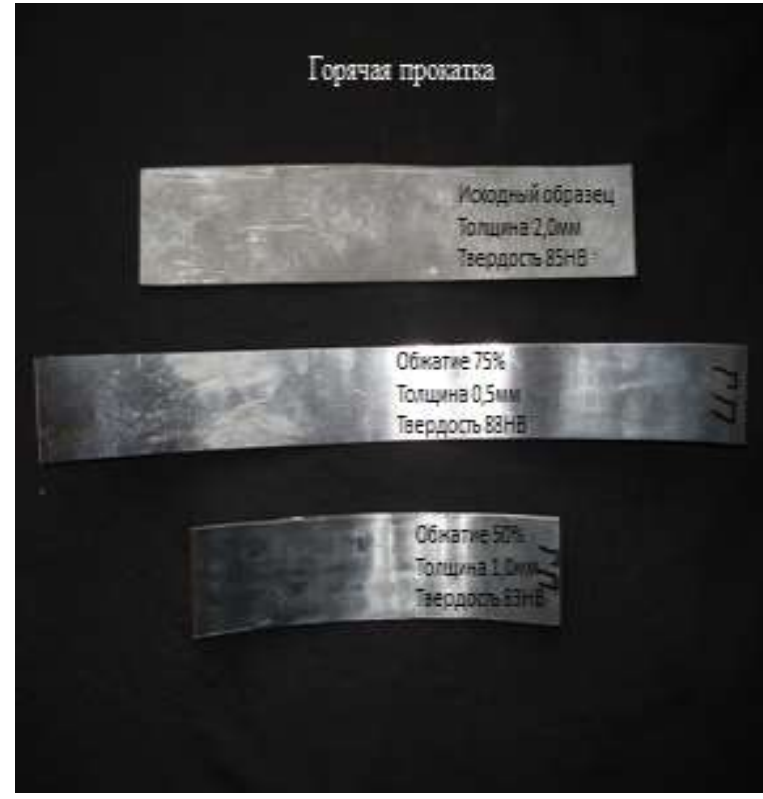

$\sigma$

Рисунок 1. Литье ленты на валковой установке $(a)$ и внешний вид образцов в литом виде и после прокатки (б)

В ходе исследований установлено, что микроструктура сплава Д16 в литом состоянии состоит из дендритов $\alpha$-Al твердого раствора различной степени разветвленности, в междендритных пространствах которых образуется эвтектика $\alpha-\mathrm{Al}-\Theta\left(\mathrm{CuAl}_{2}\right)-\mathrm{S}\left(\mathrm{Al}_{2} \mathrm{CuMg}\right)-\mathrm{Mg}_{2} \mathrm{Si}$ (рис. 2 a). Комплексная обработка сплава по схеме «валковая разливка + горячая прокатка» меняет его микроструктуру. Пластическая деформация в процессе горячей прокатки с обжатием $\varepsilon=50 \%$ приводит к ориентации первичных кристаллов $\alpha$-Al в направлении прокатки и к уменьшению их размера в плоскости, перпендикулярной поверхности листа (рис. 2 б, в). Учитывая то, что наибольшие изменения в структуре сплава Д16 проявляются в направлении действия сил деформации, представленные иллюстрации микротруктур получены с продольной поверхности образцов листа.

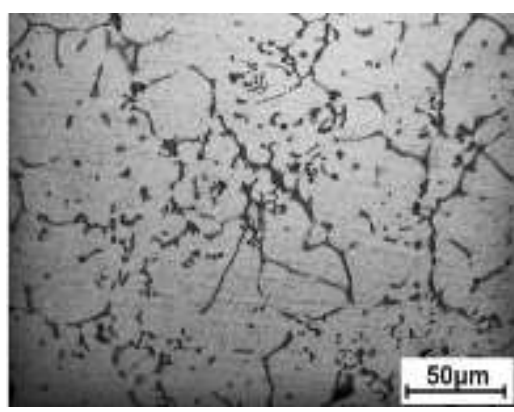

$a$

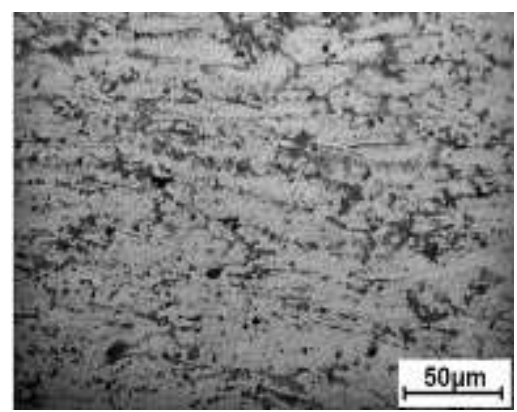

$\sigma$

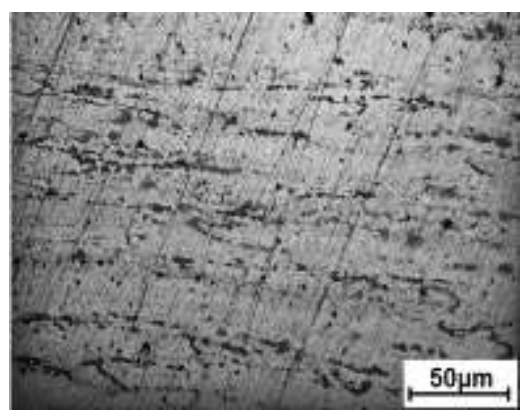

B 
Рисунок 2. Микроструктура алюминиевого сплава Д16 после валковой разливки и горячей прокатки с различными степенями деформации: $a$ - литой;

$$
\sigma-\varepsilon=50 \% ; в-\varepsilon=87,5 \%
$$

С повышением степени обжатия (с $\varepsilon=50 \%$ до $\varepsilon=87,5 \%$ ) происходит измельчение интерметаллидов, которые в основном расположены по границам дендритных ячеек и вместе с первичными кристаллами $\alpha$-Al ориентированы в направлении прокатки. Это обуславливает образование микроструктуры строчечного типа (рис. 2 в), что является следствием увеличения длины дендритных ячеек $\alpha$-Al твердого раствора и параметра их формы (рис. 3). При этом происходит уменьшение размеров и объемной доли интерметаллидов, что, вероятно, является следствием частичного их растворения при нагревании под прокатку и в процессе деформации.

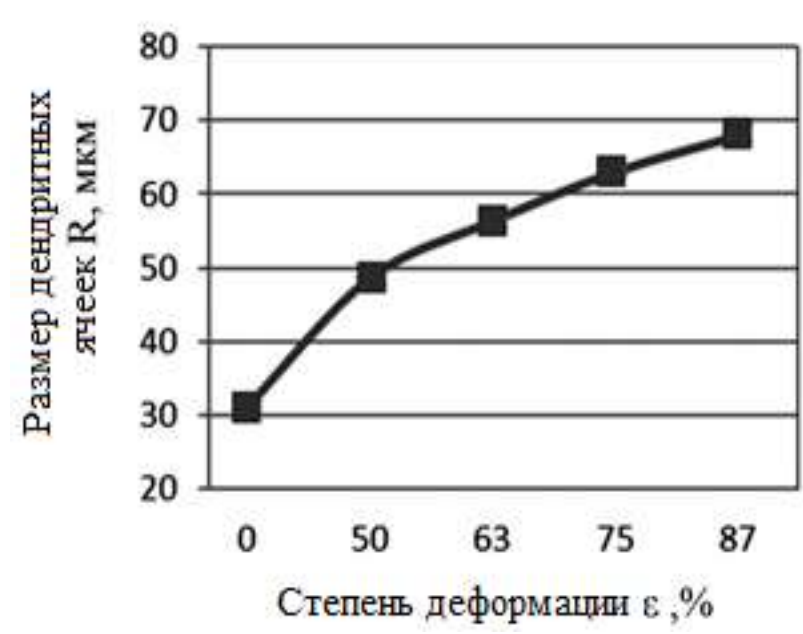

$a$

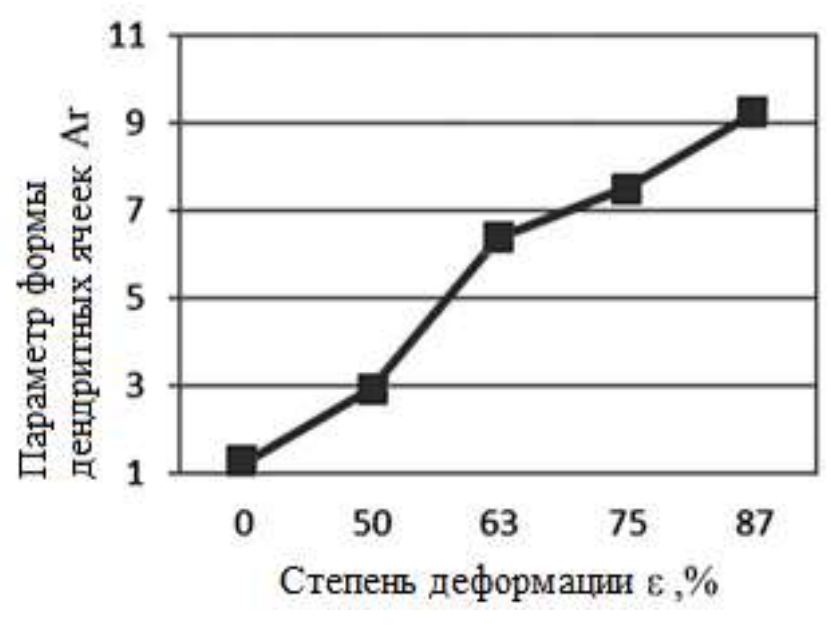

$\sigma$

Рисунок 3. Структурные характеристики образцов сплава Д16 после валковой разливки и горячей прокатки с различными степенями деформации: $a-$ зависимость размера дендритных ячеек; $\sigma$-зависимость параметра формы дендритных ячеек

Термическую обработку образцов проводили по трем схемам: 1 - отжиг при $\mathrm{T}=415^{\circ} \mathrm{C}, \tau=2$ часа, охлаждение с печью до $150^{\circ} \mathrm{C}$ и далее на воздухе; $2-$ закалка при $\mathrm{T}=495^{\circ} \mathrm{C}, \tau=30$ мин. с охлаждением в воде, старение при комнатной температуре более 3-х суток; 3 - закалка при $\mathrm{T}=495^{\circ} \mathrm{C}, \tau=30$ мин. с охлаждением в воде, старение в печи при температуре $120^{\circ} \mathrm{C}$ в течение суток и охлаждение на воздухе.

В результате проведеннях иследовоний установлены следующие закономерности изменения количественных характеристик структуры сплава Д16 (E, D, R, Ar), которые обусловлены действием технологических факторов в цепочке «валковая разливка + горячая прокатка $(\varepsilon=75 \%)+$ термическая обработка»:

- количество интерметаллидов в структуре монотонно уменьшается, что связано с их частичным растворением в $\alpha$-Al твердом растворе алюминия, 
горячая прокатка способствует измельчению интерметаллидных фаз и является стимулирующим фактором процесса их растворения;

- термическая обработка после деформации способствует уменьшению размера и параметра формы интерметаллидов, особенно при закалке со старением;

- характер изменения зависимостей размера и параметра формы дендритных ячеек $\alpha$-Al твердого раствора алюминия свидетельствует о рекристализационных процессах, которые происходят при нагревании деформированного сплава Д16.

Проведенные механические испытания показали, что эволюция структуры литой ленты из сплава Д16, которая происходит под действием внешних технологических факторов в цепочке «валковая разливка - горячая прокатка термическая обработка», существенно влияет на уровень их механических свойств, а именно: на зависимость предела прочности $\left(\sigma_{6}\right)$ и относительного удлинения $(\delta)$ от степени обжатия $\sum_{\mathrm{i}}=\frac{h_{0}}{h_{i}}$, где $h_{0}-$ толщина литой ленты, $h_{i}-$ толщина ленты после і-го обжима (рис. 4).

Данные, приведенные на рис. 4, свидетельствуют, что литая лента $(\Sigma=1)$ характеризуется низкими показателями предела прочности $\left(\sigma_{s}\right)-250 \pm 50$ МПа и относительного удлинения $(\delta)-0 \ldots 2 \%$. Горячая прокатка стимулирует повышение механических свойств, к примеру, предел прочности при обжатии $\varepsilon$ $=50 \%(\Sigma=2)$ достигает максимального значения $(\approx 450$ МПа). Надо полагать, что такие высокие показатели прочности обусловлены структурными изменениями, связанными с растворением интерметаллидных фаз и соответственно увеличением пересыщенности твердого раствора алюминия. При этом относительное удлинение $(\delta)$ также значительно увеличивается и продолжает расти с увеличением степени деформации, что, вероятно, связано с уменьшением размера и параметра формы кристаллов как твердого раствора алюминия, так и интерметаллидных фаз.
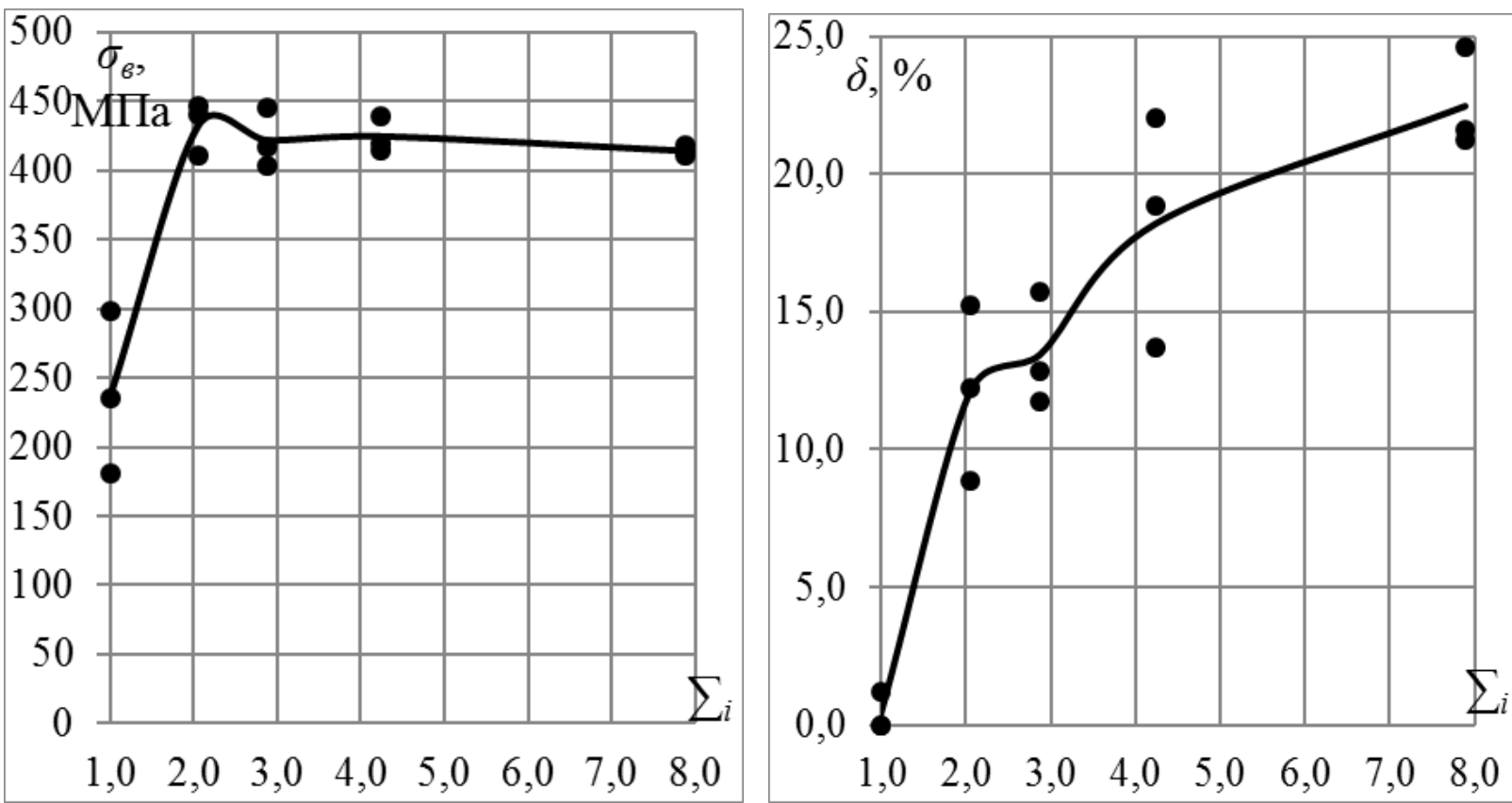
$a$

$\sigma$

Рисунок 4. Зависимость предела прочности $\sigma_{b}(a)$ и относительного удлинения $\delta$

(б) ленты из сплава Д16 от степени обжатия $\sum_{i}$ при горячей прокатке

Таким образом, по результатам проведенных исследований можно сделать следующие выводы:

- впервые в мировой металлургической практике методом валковой разливки получена литая лента из алюминиевого сплава Д16 с широким интервалом затвердевания (более $130^{\circ} \mathrm{C}$ );

- на каждом из этапов технологической цепочки «валковая разливка горячая прокатка - термическая обработка» происходят существенные изменения структуры литой ленты;

- эволюция структуры ленты, обусловлена технологическими факторами влияния в процессе валковой разливки, горячей прокатки и термической обработки, взаимосвязана с ее механическими свойствами;

- горячая прокатка лент, полученных методом валкового литья, существенно увеличивает их механические свойства: кратковременная прочность ленты приобретает максимума ( $\approx 450 \mathrm{MПа)} \mathrm{при} \mathrm{степени} \mathrm{деформации}$ $50 \%(\Sigma=2)$; относительное удлинение $(\delta=20 \ldots 22 \%)-$ при 6..8- кратном обжатии;

- полученные механические свойства ленты из сплава Д16 превышают существующие аналоги и значительно выше требований действующих стандартов.

\section{Список литературы}

1. Смирнов А.Н., Куберский С.В., Смирнов Е.Н. Будущее непрерывной разливки стали: тонкий лист // Черная металлургия: Бюл. института «Черметинформация». - 2018. - №4. - С. 73-78.

2. Killmore C.R., Greely H., Phillips A. Development of ultra-thin cast strip products the CASTRIP-process // Materials Forum. - 2008. - V. 32. - P. 12-28.

3. Lindenberg H.U. u. a. Steel Research. - 2001. - V. 11-12. - P. 727-735.

4. А.В.Ноговицын, А.С.Нурадинов, А.Л.Гончаров и др. Влияние горячей прокатки на механические свойства литой ленты из сплава Д16 // Материалы $\mathrm{X}$ Международной научно-технической конференции «Теоретические и практические проблемы в обработке материалов давлением и качества профессионального образования», Киев-Херсон, 19-22 апреля 2019 года. C.18-19.

5. А.В.Ноговищылн, А.С.Нурадинов, А.Л.Гончаров и др. Механические свойства полосы из сплава Д16, полученой методом валковой разливки // Труды международной научно-практической конференции: «Современные тенденции развития металлургических и литейных технологий», Грозный, ГГНТУ, 29 октября 2019 года. - С.81-83.

6. А.В.Ноговицьин, А.С.Нурадинов, А.Г.Прыгунова, В.З.Куцуова, Т.А.Аюпова, И.А.Нурадинов Структура и свойства литой ленты из сплава Д16 в 
технологической цепочке «валковая разливка - горячая прокатка термическая обработка» // Металловедение и обработка металлов, 2020, №2, c. $49-59$. 


\title{
ХИМИКО-ТЕХНОЛОГИЧЕСКИЕ ОСОБЕННОСТИ ПЕКТИНОВЫХ ВЕЩЕСТВ ДИКОРАСТУЩЕЙ МУШМУЛЫ (MESPILUS GERMANICA L.) АЗЕРБАЙДЖАНА
}

\author{
Фарзалиев Эльсевар Баба оглы, \\ Кандидат технических наук, Доцент, Доцент \\ Азербайджанский Государственный Экономический Университет (UNEC) \\ Голубев Владимир Николаевич, \\ Доктор химических наук, Профессор, Научный руководитель \\ Научно-технологический парк Университета Жироны
}

Успешное развитие экономики Азербайджана тесно связано и с рациональным использованием природного растительного сырья, поиском новых экологически чистых органических источников биологически активных соединений.

Пектины, выделяемые из непищевых растений, представляют основу ряда лекарственных средств и биологически активных добавок, а из пищевых растений и плодов являются важным компонентом пищевого рациона человека. Последние входят в группу так называемых «пищевых волокон» с большим сродством к организму человека выработанным за многовековой период их потребления.

Пектиновые вещества включают нерастворимую форму - протопектин, растворимые пектиновые полисахариды и сопутствующие им галактаны, арабинаны и арабиногалактаны [1]. Пектиновые полисахариды (пектины) входят в большую группу гликаногалактуронов - кислых растительных полисахаридов, главную углеводную цепь которых составляют 1,4-связанные остатки альфа-Дгалактопиранозилуроновой кислоты [2]. Пектиновые макромолекулы включают в себя следующие основные структурные области: линейная область гомогалактуронана состоит из 1,4-связанных остатков альфа-Dгалактопиранозилуроновой кислоты, соединенными между собой одним или двумя 1,2-связанными остатками альфа-L-рамнопиранозы, образуя линейную область рамногалактуронана как главной углеводной цепи макромолекулы. Разветвленная область состоит из рамногалактуронана, содержащего линейную цепь галактуронана и боковые углеводные цепи из остатков галактозы, арабинозы. Кроме того, возможно наличие в разветвленной области фрагментов ксилогалактуронана, в котором к цепи галактуронана 1,3-гликозидной связью присоедены одиночные остатки бэта-D-ксилопиранозы, a также апиогалактуронана. В последнем одиночные 1,2- или 1,5-связанные остатки Dапиозы присоединяются 1,2- или 1,3-связями к остаткам D-галактуроновой кислоты главной углеводной цепи [2]. Главная углеводная цепь галактуронана содержит метилэтерифицированные остатки D-галактуроновой кислоты, кроме 
того, в состав макромолекулы входят сложноэфирные О-ацетильные группы, локализация которых носит случайный характер в зависимости от природы растительного сырья. Молекулярная масса пектиновой макромолекулы варьирует в широких пределах от 10 до 150 кДа и зависит не только от вида пектинсодержащего сырья, но и от способа выделения пектиновых веществ. Экстракция водой создает слабокислые условия, в которых экстрагируются только водорастворимые пектиновые фракции. В этих условиях частично отщепляются боковые цепи, что снижает физиологическую активность полученного пектинового продукта. Другой метод экстракции представляет собой последовательную экстракцию водными ионными растворами, которые приводят к извлечению не только водорастворимой фракции, но также и пектиновых фрагментов протопектина. В этом случае получается пектин с большей молекулярной массой и более высокой степенью метилэтерифицирования остатков D-галактуроновой кислоты в углеводной цепи галактуронана. Полученные пектиновые фракции обладают высокой способностью образовывать комплексы с металлами, белками и другими компонентами растительных клеток, а также проявлять и разнообразную физиологическую активность, в том числе иммунологическую [3]. Пектиновая макромолекула содержит фрагменты, способные снижать или увеличивать иммуномодулирующее действие. Использование с этой целью фрагментов главной углеводной цепи и разветвленных областей пектина представляется перспективной задачей при исследовании новых природных источников пектиновых веществ.

Многоплановый спектр присущих пектину свойств обуславливает и его широкое применение в медицинской и пищевой промышленности, в технологиях производства здоровых продуктов питания и в частности, при производстве продуктов лечебно-профилактического направления [4]. Чаще всего для этих целей используются коммерческие пектины (яблочный, цитрусовый, свекловичный и др.). В тоже время большой интерес представляет использование местного дикорастущего пектинсодержащего сырья, в которой помимо пектиновых веществ присутствует уникальный биологически-активный комплекс. Физиологическая активность и технологические свойства пектинов дикорастущего сырья зависит от качества используемого растительного сырья, условий экстракции пектина, а также от структурных особенностей пектиновой макромолекулы и баланса ее функциональных групп.

Было установлено, что на углеводный профиль химического состава свежих плодов мушмулы приходится 79,80 \% сухих веществ, присутствуют моносахара (в основном глюкоза и фруктоза) и полисахариды первого порядка (в основном дисахарид сахароза) и второго порядка (крахмал, целлюлоза, гемицеллюлоза пектин). При этом оказалось, что содержание пектиновых веществ достаточно высокое - 3,70\%, причем на водорастворимую фракцию пектина приходится порядка 70\% от общего содержания, что представляет значительный практический интерес для производства биопродукта не только, как будет показано ниже, с высокой желирующей способностью, но и с лечебнопрофилактическими функциями. Значительное содержание пектиновых 
веществ, и в частности, водорастворимой фракции послужило основанием для более детального исследования его технологических свойств с целью получения функционального пюреобразного продукта , в котором протопектиновая фракция переведена в форму активированного пектина [5], т.е. перевод $30 \%$ протопектина в водорастворимое состояние за счет использования в рецептуре биопродукта гидролизующего агента и физического эффекта гидроакустической обработки исходного сырья [1].

Таблица 1.

Результаты анализов основных физико-химических показателей активированных пектиновых веществ биопродукта «Пюре натуральное из мушмулы»

\begin{tabular}{|c|l|c|c|}
\hline № & \multicolumn{1}{|c|}{ Показатели } & $\begin{array}{c}\text { Единица } \\
\text { измерения }\end{array}$ & Количества \\
\hline 1 & Галактуроновая кислота & $\%$ & 75,50 \\
\hline 2 & Метоксильные группы & $\%$ & 6,89 \\
\hline 3 & Степень этерифицирования & $\%$ & 56,85 \\
\hline 4 & Молекулярная масса & Да & 33500 \\
\hline 5 & рН 0,5 \%-ного водного раствора & - & 2,48 \\
\hline 6 & Желирующая способность & ${ }^{0} \mathrm{SAG}$ & 176,0 \\
\hline
\end{tabular}

Из полученных данных следует, что пектин плодов мушмулы можно отнести к высокоэтерифицированному пектину, т.е. он способен образовывать высокоэластичные гели и проявлять высокую сорбционную способность по отношению к тяжелым металлам. Нами были также изучены инфракрасные спектры пектинового образца мушмулы в области 700-3800 $\mathrm{cm}^{-1}$, поскольку известно [6] что ИК-спектры дают важную информацию о составе и структуре пектиновой макромолекулы, а также определить чистоту пектинового препарата. Известно, что полосы ИК-поглощения первичных гидроксильных групп наблюдаются в области 3590-3650 $\mathrm{cm}^{-1}$, а вторичные гидроксильные группы в области 3450-3500 $\mathrm{cm}^{-1}$, что мы и наблюдали и что объясняется наличием большого количества свободных гидрокарбоксильных групп, а также в небольшом количестве $-1,5 \%$ ацетильных групп. Интенсивная полоса поглощения в области 1740-1700 $\mathrm{cm}^{-1}$ указывает на значительное содержание метоксильных групп.

Заключение. Исследование сорбционной способности образца активированного пектина мушмулы in vitro по отношению к токсичным тяжелым металлам $(\mathrm{Hg}, \mathrm{Pb}, \mathrm{Cd})$ показало, что сорбционная способность, которая может быть выражена количеством тяжелых металлов, связанного полностью с 1 г пектина составляет $35-58 \%$ от внесенного количества металлов и возрастает в ряду: $\mathrm{Cd}-\mathrm{Hg}-\mathrm{Pb}$. Полученные нами данные показывают, что изучение связи между структурой и активностью пектинов из новых видов природного дикорастущего сырья представляется актуальной задачей и позволяет вовлечь в производство функциональных биопродуктов новые сырьевые органические источники. 


\section{Список литературы}

1. Голубев В.Н., Шелухина Н.П. Пектин: химия, технология, применение. М.: Издательство Академии технологических наук РФ, 1995. - 485 с.

2. Оводов Ю.С. Современные представления о пектиновых веществах // Биоорганическая химия, 2009, т.35, №3, с.298-310.

3. Оводов Ю.С. Оводова Р.Г., Попов С.В. Биогликаны-иммуномодуляторы. Строение и свойства //Фитотерапия. биологически активные вещества естественного происхождения. ЗАО «Биопрогресс»., Черноголовка, 2004. С. 348363.

4. Гаппаров М.Г. Функциональные продукты питания.// Пищевая промышленность, 2003, №3, с.5-8.

5. Голубев В.Н., Шелухина Н.П., Волкова И.В. Новая технология овощефруктовых паст с активированным пектином // Пищевая промышленность, 1993, №11, с.18-20.

6. Anna F. Torcjva, Ivan S. Filimonov, Galina S. Kachalova, Vladimir N. Golubev, Tatyana V. Fedorova Physicochemical and functional properties of Cucurbita maxima pumpkin pectin and commercial citrus and apple pectins: A comparative evalution // PLOG one, 2018, September 20, p.1-24. 
The authors of the XII International Scientific and Practical Conference «Advances in Technology and Science» were representatives of the following educational institutions:

Uman National University of Horticulture; National Forestry University of Ukraine; Bila Tserkva National Agrarian University; Kharkiv National Agrarian University named after V.V. Dokuchayev; TUS filial Politehnic; Lviv National Academy of Arts; Kharkiv Humanitarian-Pedagogical Academy; Academician Yuri Bugay International Scientific and Technical University; Kyiv National University of Trade and Economics; National Transport University; Kharkiv National University of Civil Engineering and Architecture; Kyiv National University of Technologies and Design; Izmail State Humanitarian University; Institute of Industrial Economics; Taraz State University; Odesa State Economic University; Odesa State Ecological University; T.H. Shevchenko National University «Chernihiv Colehium»; Borys Grinchenko Kyiv University; National Aviation University; Zaporizhzhya National University; Kryvyi Rih comprehensive school of I-III degrees; Medizinische Akademie Dnipropetrowsk des Gesundheitsministeriums; Institute of General and Urgent Surgery. V.T. Zaitseva; Ivano-Frankivsk National Medical University; Institute of Medical Radiology of S. P. Grigoriev; National Academy of Medical Sciences of Ukraine Volyn National University named after Lesya Ukrainka; Central Ukrainian National Technical University; South Ukrainian National Pedagogical; University named after K. D. Ushynsky; West Ukrainian National University; Igor Sikorsky Kyiv Polytechnic Institute; Institute of Problems on Education; Ternopil Volodymyr Hnatiuk National Pedagogical University; Vinnytsia National Pirogov Medical University; Pavel Tychyna Uman State Pedagogical University; Novoushitska special school; Cherkasy Medical Academy; Igor Sikorsky Kyiv Polytechnic Institute; Poltava National Technical University; Ivan Franko National University of Lviv; Vasyl Stefanyk Precarpathian National University; Kyiv University of Civil Building and Architecture; Taras Shevchenko National University of Kyiv; Georgian Technical University; Lesya Ukrainka Eastern European National University; V. G. Korolenko National Pedagogical University; Lviv Polytechnic National University; Ukrainian Academy of Printing; Zaporizhzhia National University; Dnipro University of Technology; Cherkasy State Technological University; Lviv National Stepan Gzhytsky University of Veterinary Medicine and Biotechnology; National Technical University "Kharkiv Polytechnic Institute"; Lutsk National Technical University; Grozny State Oil; Technical University, named after academician M.D. Millionshchikov; North Caucasus Mining and Metallurgical Institute; Azerbaijan State Economic University; University of Girona. 


\section{ADVANCES IN TECHNOLOGY AND SCIENCE}

\section{Scientific publications}

Materials of the XII - the International Science Conference «Advances in Technology and Science», Berlin, Germany. 294 p. (March 16 - 19, 2021)

Text Copyright (C) 2021 by the International Science Group(isg-konf.com). Illustrations (C) 2021 by the International Science Group. Cover design: International Science Group(isg-konf.com) ${ }^{\oplus}$ Cover art: International Science Group(isg-konf.com) ${ }^{\odot}$

All rights reserved. Printed in the United States of America.

No part of this publication may be reproduced, distributed, or transmitted, in any form or by any means, or stored in a data base or retrieval system, without the prior written permission of the publisher.

The content and reliability of the articles are the responsibility of the authors. When using and borrowing materials reference to the publication is required. Collection of scientific articles published is the scientific and practical publication, which contains scientific articles of students, graduate students, Candidates and Doctors of Sciences, research workers and practitioners from Europe, Ukraine, Russia and from neighboring countries and beyond. The articles contain the study, reflecting the processes and changes in the structure of modern science. The collection of scientific articles is for students, postgraduate students, doctoral candidates, teachers, researchers, practitioners and people interested in the trends of modern science development.

The recommended citation for this publication is: Vyshnevska L., Sichkar A., Rogalskiy S. Productivity of sugar beet hybrids under the conditions of right-bank forest-steppe of Ukraine // Advances in Technology and Science. Abstracts of XII International Scientific and Practical Conference. Berlin, Germany 2021. Pp. 11-12.

URL: https://isg-konf.com. 